VILNIAUS GEDIMINO TECHNIKOS UNIVERSITETAS

Vaiva DEVEIKIENÉ

\title{
KRAŠTOVAIZDŽIO ARCHITEKTŪROS IR URBANISTIKOS SĄVEIKA
}

DAKTARO DISERTACIJA

HUMANITARINIAI MOKSLAI, MENOTYRA $(03 \mathrm{H})$ 
Disertacija rengta 2014-2018 metais Vilniaus Gedimino technikos universitete. Vadovas

doc. dr. Gintaras STAUSKIS (Vilniaus Gedimino technikos universitetas, menotyra $-03 \mathrm{H})$.

Vilniaus Gedimino technikos universiteto Menotyros mokslo krypties disertacijos gynimo taryba:

\section{Pirmininkas}

doc. dr. Edita RIAUBIENE (Vilniaus Gedimino technikos universitetas, menotyra $-03 \mathrm{H})$.

\section{Nariai:}

prof. dr. Petras GRECEVIČIUS (Klaipedos universitetas, menotyra - 03H), dr. Jūratė KAMIČAITYTĖ-VIRBAŠIENĖ (Kauno technologijos universitetas, menotyra $-03 \mathrm{H}$ ),

dr. Patrick MOQUAY (Versalio nacionalinè aukštoji kraštovaizdžio architektūros mokykla, politikos mokslai - 02S),

doc. dr. Rasa UŠPALYTĖ-VITKŪNIENĖ (Vilniaus Gedimino technikos universitetas, statybos inžinerija - 02T).

Disertacija bus ginama viešame Menotyros mokslo krypties disertacijos gynimo tarybos posėdyje 2019 m. sausio 28 d. 10 val. Vilniaus Gedimino technikos universiteto senato posèdžių salëje.

Adresas: Sauletekio al. 11, LT-10223 Vilnius, Lietuva.

Tel.: (8 5) 274 4956; faksas (8 5) 270 0112; el. paštas doktor@vgtu.lt

Pranešimai apie numatomą ginti disertaciją išsiųsti $2018 \mathrm{~m}$. gruodžio $27 \mathrm{~d}$.

Disertaciją galima peržiūrèti VGTU talpykloje http://dspace.vgtu.lt ir Vilniaus Gedimino technikos universiteto bibliotekoje (Sauletekio al. 14, LT-10223 Vilnius, Lietuva), Klaipédos universiteto bibliotekoje (K. Donelaičio al. 3, LT-92144 Klaipéda, Lietuva)

VGTU leidyklos TECHNIKA 2018-022-M mokslo literatūros knyga http://leidykla.vgtu.lt

ISBN 978-609-476-149-2

(C) VGTU leidykla TECHNIKA, 2018

(C) Vaiva Deveikienè, 2018

vaivadeveikiene@gmail.com 
VILNIUS GEDIMINAS TECHNICAL UNIVERSITY

Vaiva DEVEIKIENÉ

\section{INTERACTION BETWEEN LANDSCAPE ARCHITECTURE AND URBANISM}

DOCTORAL DISSERTATION

HUMANITIES,

HISTORY AND THEORY OF ARTS $(03 \mathrm{H})$ 
Doctoral dissertation was prepared at Vilnius Gediminas Technical University in 2014-2018.

\section{Supervisor}

Assoc. Prof. Dr Gintaras STAUSKIS (Vilnius Gediminas Technical University, History and Theory of Arts $-03 \mathrm{H}$ ).

The Dissertation Defence Council of Scientific Field of History and Theory of Arts of Vilnius Gediminas Technical University:

\section{Chairman}

Assoc. Prof. Dr Edita RIAUBIENE (Vilnius Gediminas Technical University, History and Theory of Arts $-03 \mathrm{H}$ ).

\section{Members:}

Prof. Dr Petras GRECEVIČIUS (Klaipèda University, History and Theory of Arts $-03 \mathrm{H})$,

Dr Jūratė KAMIČAITYTĖ-VIRBAŠIENE (Kaunas University of Technology, History and Theory of Arts $-03 \mathrm{H}$ ),

Dr Patrick MOQUAY (National School of Landscape Architecture in Versailles, France, Political Sciences - 02S),

Assoc. Prof. Dr Rasa UŠPALYTĖ-VITKŪNIENE (Vilnius Gediminas Technical University, Civil Engineering - 02T).

The dissertation will be defended at the public meeting of the Dissertation Defence Council of Scientific field of History and Theory of Arts in the Senate Hall of Vilnius Gediminas Technical University at 10 a. m. on 28 January 2019.

Address: Saulètekio al. 11, LT-10223 Vilnius, Lithuania.

Tel.: +370 5274 4956; fax +370 5270 0112; e-mail: doktor@vgtu.lt

A notification on the intend defending of the dissertation was send on 27 December 2018.

A copy of the doctoral dissertation is available for review at VGTU repository http://dspace.vgtu.lt and at the Library of Vilnius Gediminas Technical University (Sauletekio al. 14, LT-10223 Vilnius, Lithuania) and the Library of Klaipėda University (K. Donelaičio al. 3, LT-92144 Klaipėda, Lithuania) 


\section{Reziumè}

Šiuolaikiniame moksle ir praktikoje kraštovaizdžio architektūros kompetencijų sričiai priskiriami vis sudètingesni miesto tvarkymo, atnaujinimo ir vystymo uždaviniai. Miestas yra daugiafunkcinis organizmas, todèl planuotojai, urbanistikos bei kraštovaizdžio mokslininkai ieško būdų, kaip kartu spręsti iškylančius tarpdisciplininius klausimus, kurių centre, be abejo, yra žmoniu gerovès poreikiai. Disertacijoje nagrinėjama kraštovaizdžio architektūros ir urbanistikos sąveikos tema. Tyrimu ieškoma atsakymų, kaip kraštovaizdžio architektūra gali būti naudinga siekiant tvaraus gamtos ir miesto sambūvio, kas sudaro kraštovaizdžio architektūros kūrybos lauką miesto aplinkoje bei, kas lemia kraštovaizdžio architektūros priemonių raišką urbanistiniame kraštovaizdyje. Tyrimo tikslas - atskleidžiant kraštovaizdžio architektūros raidą ir vaidmenį mieste, sukurti tvaraus vystymosi principais paremtą kraštovaizdžio architektūros ir urbanistikos sprendinių sąveikos optimizavimo metodinị modelį.

Disertaciją sudaro įvadas, trys skyriai, bendrosios išvados, naudotos literatūros sąrašas, priedai. İvade pristatoma disertacijoje nagrinèjama problema, jos aktualumas, tyrimo objektas, darbo metodai, naujumas, ginamieji teiginiai ir darbo struktūra. Pirmajame skyriuje aptariama kraštovaizdžio architektūros sampratos evoliucija, kraštovaizdžio architektūros profesinès veiklos laukas, kraštovaizdžio architektūros raiška XIX-XXI amžių urbanistiniuose procesuose. Analizuojami ir apibendrinami kraštovaizdžio ir urbanistikos sąsajų mokslinių tyrimų aspektai bei miesto aplinkos tyrimų metodai. Antrajame skyriuje kuriami kraštovaizdžio architektūros ir urbanistikos sąveikos tyrimo metmenys. Tiriami šešių Lietuvos miestų bendrųjų planų sprendiniai gamtinio karkaso ir želdynų sistemos vystymo ir kraštovaizdžio architektūros aspektu, analizuojama Lietuvos ir užsienio ekspertų nuomonè dèl kraštovaizdžio architektūros vaidmens miesto kūrime. Sudaromas kraštovaizdžio architektūros ir urbanistikos sprendinių sąveikos tyrimo modelis: nustatomi pagrindiniai optimalios sąveikos principai, sudaroma tvarumo ir ekologinès etikos principais grịsta trinaré tyrimo kriterijų sistema. Trečiajame skyriuje pristatomas kraštovaizdžio architektūros ir urbanistikos sprendinių sąveikos optimizavimo metodinis modelis, kuriame sąveikos tyrimo rezultatai interpretuojami ir konceptualizuojami taikant kraštovaizdžio architektūros metodus. Aptariamos sąveikos optimizavimo metodinio modelio mokslinio ir praktinio pritaikymo ekonominès, teisinès ir tvaraus miesto planavimo sąlygos.

Disertacijos tema paskelbti penki straipsniai recenzuojamuose mokslo žurnaluose ir trys kituose recenzuojamuose leidiniuose. Be to, disertacijos tema perskaityti šeši pranešimai ir pristatytas vienas stendinis pranešimas Lietuvos bei kitų šalių mokslinėse konferencijose. 


\section{Abstract}

In the contemporary world of science and practice, the landscape architecture's area of expertise includes increasingly complex tasks related to the city management, renewal and development. City planners, urban and landscape researchers agree on a number of emerging interdisciplinary issues, as the city is a multifunctional organism undoubtedly having human well-being needs as its centrepiece. Dissertation deals with the topic of interaction between landscape architecture and urbanism. The research seeks to answer how landscape architecture can be beneficial in pursuit for the sustainable coexistence of nature and the city, what forms the creative field of landscape architecture in the urban environment and what determines the optimal expression of landscape architectural means in the urban landscape. The aim of the research is to reveal the development and role of landscape architecture in the city, to develop a methodological model for optimizing interaction between landscape architecture and urbanism solutions. The dissertation consists of the introduction, three chapters, general conclusions, list of references, and annexes. The introduction introduces the problem analysed in the dissertation, its relevance, the object of research, work methods, novelty, and statements of defence and structure of work. The first chapter discusses the evolution of the concept of landscape architecture, the field of professional activity of landscape architecture, and the expression of landscape architecture in the urbanism processes of the 19th to the 21 st centuries, analyzes and summarizes the aspects of research on the interaction of landscape and urbanism, as well as methods of urban environmental research. The second chapter creates the framework of the interaction between the solutions of landscape architecture and urbanism. The solutions of the general plans in the aspect of landscape architecture are explored. The dissertation contains examination and analysis of the opinion of experts from Lithuania and abroad on the role of landscape architecture in the development of the city. The model of the analysis of interaction between landscape architecture and urbanism solutions is compiled: establishing the main principles of optimal interaction, preparing a three-dimensional system of test criteria based on the principles of sustainability and ecological ethics. The third chapter presents a methodical model for optimizing the interaction of landscape architecture and urbanism solutions, in which the results of the interaction research are interpreted and conceptualized using landscape architecture methods. A total of five articles were published in peer-reviewed scientific journals and three in in other peerreviewed publications on the topic of the dissertation. In addition, six presentations and one poster presentation on the subject of the dissertation were presented at the scientific conferences of Lithuania and other countries. 


\section{Žymèjimai}

\section{Santrumpos}

AHP - Analytic Hierarchy Process (analitinès hierarchijos procesas);

angl. - anglų kalba;

asm. - asmuo, asmenys;

$\mathrm{BP}$ - bendrasis planas, bendrieji planai;

CIAM - Congrès internationaux d'architecture moderne (Modernios architektūros tarptautiniai kongresai);

cit. - cituota, cituojama;

deš. - dešimtmetis;

ECLAS - European Council of Landscape Architecture Schools (Europos kraštovaizdžio architektūros mokyklų taryba);

EFLA - European Federation for Landscape Architecture (Europos kraštovaizdžio architektūros federacija);

ENSP - École nationale supérieure du paysage (Versalio nacionalinė aukštoji kraštovaizdžio architektūros mokykla);

ES - Europos Sajunga;

etc. - lot. et cetera ,ir kita, ir taip toliau“;

GIS - geografinė informacinè sistema (angl. Geographical Information System); 
ha - hektaras, hektarai;

IFLA - International Federation of Landscape Architecture (Tarptautinè kraštovaizdžio architektūros federacija);

JAV - Jungtinès Amerikos Valstijos;

ISCO - Tarptautinis standartinis profesijų klasifikatorius;

km - kilometras, kilometrai;

kt. - kiti, kitkas;

kv. - kvadratinis;

LAREP - Laboratoire de recherche en projet de paysage (kraštovaizdžio architektūros tyrimų laboratorija);

LPK - Lietuvos profesijų klasifikatorius;

lot. - lotynų kalba;

$\mathrm{m}$ - metras, metrai;

m. - metai;

MCDM - Multi Criteria Decision Making (daugiakriterinès analizès metodas);

min. - minuté, minutès;

nagr. - nagrinèjamas, nagrinėjami;

p. - pusè, pusèje;

pab. - pabaiga, pabaigoje;

pan. - panašiai;

pav. - paveikslas;

pranc. - prancūzų kalba;

pvz. - pavyzdžiui, pavyzdys;

SFU - Socié té française des urbanistes (Prancūzijos urbanistų sajunga);

sk. - skyrius;

t. y. - tai yra;

ter. - teritorija, teritorijos;

UNESCO - United Nations Educational, Scientific and Cultural Organization (Jungtiniu Tautų švietimo, mokslo ir kultūros organizacija);

vid. - vidurys, vidurio;

vnt. - vienetas, vienetai;

vok. - vokiečių kalba;

žr. - žiūrèti. 


\section{Pagrindinès sąvokos}

Atviroji miesto erdvè (angl. Urban Open Space) - disertacijoje suprantama, kaip bet kuri neužstatyta, tačiau betarpiškai su pastatais ar infrastruktūros statiniais susijusi miesto erdvè, pritaikoma žmonių būvimui ar judejimui.

Gamtinis karkasas - vientisas gamtinio ekologinio kompensavimo teritorijų tinklas, užtikrinantis ekologinę kraštovaizdžio pusiausvyrą, gamtinius ryšius tarp saugomų teritorijų, kitu aplinkosaugai svarbių teritorijų ar buveinių, taip pat augalų ir gyvūnų migraciją tarp jų (LR Saugomų teritorijų i̇statymas 2001). Gamtinis karkasas mieste turi savo ypatumu - išskirtini trys jo prioritetai: ekologinio kompensavimo; socialiai orientuotos rekreacinès funkcijos ir architektūrinio kompozicinio vaidmens.

Kraštovaizdis - tai žmonių suvokiama vietove, kurios pobūdị nulėmė gamtos ir (arba) žmonijos veiksnių veikimas ir sąveika (Europos kraštovaizdžio konvencija 2000).

Kraštovaizdžio architektūra (angl. Landscape architecture) - taikomoji mokslo ir meno disciplina, formuojanti žmogaus erdvinę aplinką: statinių ir jų kompleksų dermę su kraštovaizdžio gamtiniu pagrindu ar jo atskirais elementais. (Lietuvos Respublikos kraštovaizdžio politikos krypčių aprašas 2004). Kraštovaizdžio architektūra - profesinès veiklos sritis ir akademinè disciplina, yra susijusi su ịvairių kraštovaizdžių formavimu. Tai apima kraštovaizdžio planavimą, projektavimą ir valdymą, siekiant kurti, tobulinti, palaikyti ir saugoti vietas, kad kraštovaizdis būtų funkcionalus, estetiškas, prasmingas ir tvarus bei atitiktu ìvairias žmonių poreikius ir tikslus (ECLAS 2010)

Kūrybinis laukas (angl. Creative field) šiame darbe aprẻpia tiek fizini, tiek kultūrinịmentalini profesinès veiklos lauką, kurio ribas lemia kompetencijos bei teisinès, politinès, kultūrinès, etinès, ekonominès ir kitos nuostatos.

Optimizavimas (angl. optimizing) - šiame darbe suprantamas bendrine prasme, kaip klausimo ar uždavinio geriausio sprendimo būdo radimas pagal iš anksto nusistatytą kriterijų (Tarptautinių žodžių žodynas 2007)

Sąveika (angl. Interaction) - abipusis vienas kitą sąlygojančių objektų, sričių ar subjektų informacinis ir praktinis veikimas ar poveikis, keičiantis visų jų būsenas. Sąveika disertacijoje suprantama, kaip ryšiai arba bendradarbiavimas abipusiam tikslo ir poveikio supratimui ir veiksmų vieningumui užtikrinti.

Sprendinys (angl. Solution) - disertacijoje sprendinių samprata apima kryptingus veiksmus, t.y. apsisprendimą kuria nors linkme siekiant numatomo rezultato. Sprendinys aprèpia tiek analize pagrịstą, skaičiavimais ir grafiškai išreikštą projektą, tiek konkrečios formuojamos aplinkos ar jos modulinių elementų sprendimų rezultatus.

Urbanistika (angl. Urbanism) - mokslo ir studijų bei profesionalios veiklos sritis, kurios objektai yra miestai, jų sistemos ir socialiniai, ekonominiai bei kiti su jų vystymusi glaudžiai susiję procesai. (Juškevičius 2013). Urbanistika (angl. Urban design) architektūros šaka, kurios pagrindiniai objektai - urbanizuotų (urbanizuojamų) teritorijų, urbanistinių kompleksų erdvinė aplinka, urbanistinè struktūra, urbanistinė erdvė ir ją formuojantys užstatymo sprendiniai. (Lietuvos Respublikos architektūros ịstatymas, 2017). 
Urbanistinis procesas (angl. Urban process) - disertacijoje suprantamas kaip bet koks su miesto plètote (vystymu), pertvarkymu ir vadyba susijęs fizinis, socialinis vyksmas.

Viešoji erdvè (angl. Public space) - gyvenamosios vietovès urbanizuotos teritorijos erdvinès struktūros elementas, skirtas visuomenès bendriesiems interesams (LR Teritorijų planavimo ịstatymas, 2014; 2017).

Žalioji infrastruktūra (angl. Green infrastructure) - strategiškai suplanuotas gamtinių ir pusiau gamtinių zonų tinklas, kuriame kiti aplinkos objektai suprojektuoti ir tvarkomi siekiant sudaryti sąlygas įvairioms ekosistemų funkcijoms. Ji apima žaliąsias zonas (arba mėlynąsias, jei tai jūrinès ekosistemos) ir kitus fizinius sausumos (įskaitant pakrantes) ir jūrinius objektus. (Komisijos komunikatas..., 2013). Disertacijoje naudojama žaliosios infrastruktūros samprata apima gamtinio karkaso, miškų ir želdynų sistemas. 


\section{Turinys}

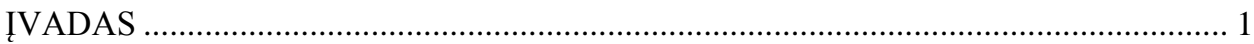

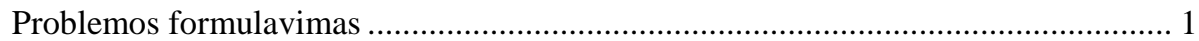

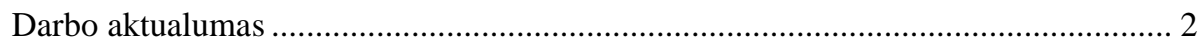

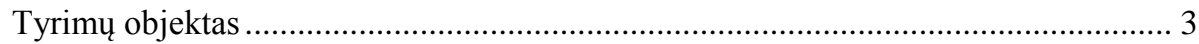

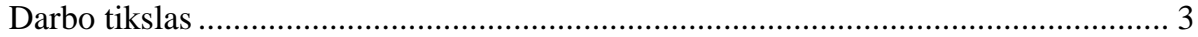

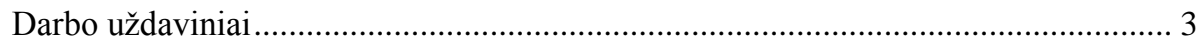

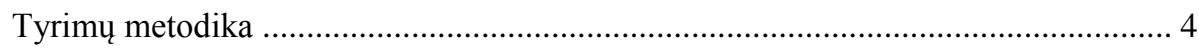

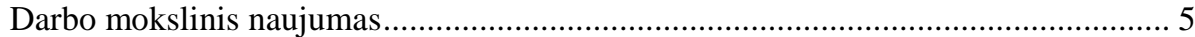

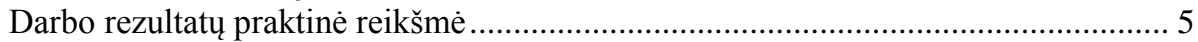

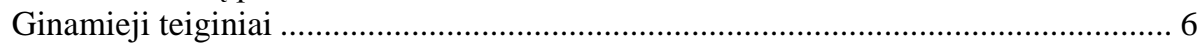

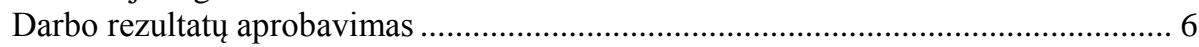

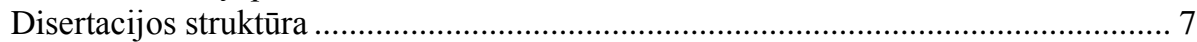

1. KRAŠTOVAIZDŽIO ARCHITEKTŪRA - SUDĖTINĖ MIESTO KŪRIMO

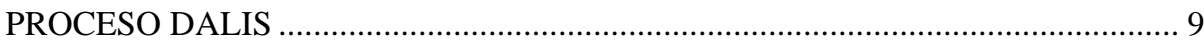

1.1. Kraštovaizdžio architektūros sampratos raida ................................................. 9

1.2. Kraštovaizdžio architektūros profesinès veiklos laukas..................................... 16

1.3. Kraštovaizdžio architektūros raiška XIX-XX amžių urbanistiniuose

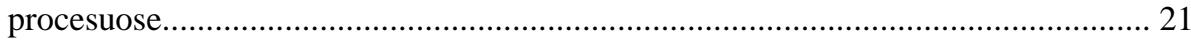

1.3.1. Miesto ir jo želdynų raida XIX-XX amžių sandūroje ................... 22

1.3.2. Modernizmo ir postmodernizmo laikotarpiai ................................ 28 
1.3.3. Šiuolaikinès kraštovaizdžio architektūros ir urbanistikos sąveikos teorijos ir praktika ............................................................. 32

1.4. Kraštovaizdžio ir urbanistikos sąveikos moksliniai tyrimai ir taikomos

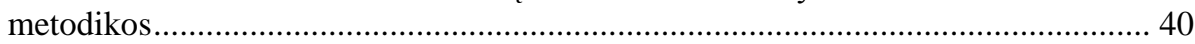

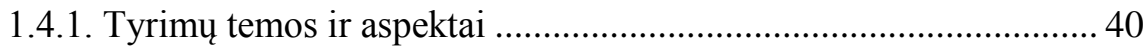

1.4.2. Miesto aplinkos tyrimų metodai .................................................. 49

1.5. Pirmojo skyriaus išvados ir disertacijos uždavinių formulavimas ..................... 55

2. KRAŠTOVAIZDŽIO ARCHITEKTŪROS IR URBANISTIKOS SĄVEIKOS

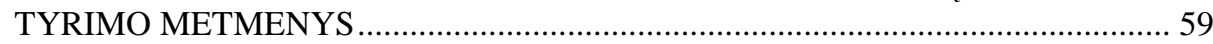

2.1. Kraštovaizdžio architektūros ir urbanistikos sprendinių sąveika teritorijų planavime.

2.1.1. Miestų bendrųų planų sprendiniai gamtinio karkaso ir želdynų

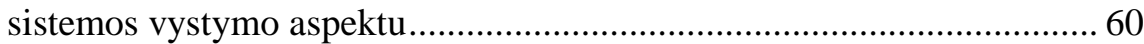

2.1.2. Bendrieji planai - kraštovaizdžio architektūros ir urbanistikos sprendinių sąveikos optimizavimo priemonè

2.2. Ekspertų nuomonių tyrimas apie kraštovaizdžio architektūros vaidmenị

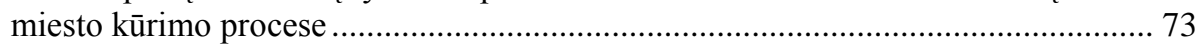

2.3. Kraštovaizdžio architektūros ir urbanistikos sprendinių sąveikos tyrimo modelio sudarymas

2.3.1. Gamtinių ir antropogeninių struktūrų sąveikos aktualizavimas .... 86

2.3.2. Pagrindiniai optimalios sąveikos principai ir nuostatos................ 90

2.3.3. Trinarès tyrimo kriterijų sistemos sudarymas .............................. 95

2.3.4. Eksperimentinis teritorijos tyrimas taikant erdvinių gardelių

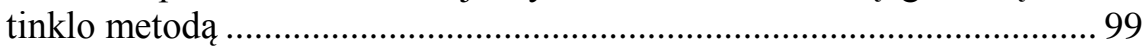

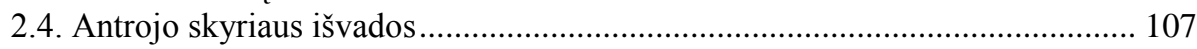

3. KRAŠTOVAIZDŽIO ARCHITEKTŪROS IR URBANISTIKOS SPRENDINIŲ

SĄVEIKOS OPTIMIZAVIMO METODINIS MODELIS ...................................... 111

3.1. Kraštovaizdžio architektūros principai sąveikos tyrimo rezultatams konceptualizuoti.....

3.2. Sąveikos tyrimo metodinio modelio taikymas įvairiuose teritoriniuose lygmenyse.

3.3. Sąveikos optimizavimo metodinio modelio mokslinio ir praktinio pritaikymo sąlygos

3.4. Trečiojo skyriaus išvados 
A priedas. Sąvokos „kraštovaizdžio architektūra“ raidos analizès suvestinè lentelè

B priedas. II skyriaus iliustracijos ir suvestinès lentelès ....................................... 178

C priedas. III skyriaus iliustracijos ir suvestinès lentelès........................................ 206

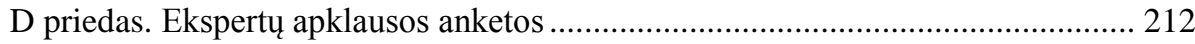

E priedas. Vertinamos teritorijos duomenys ........................................................... 219

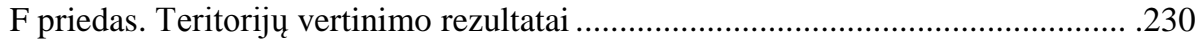

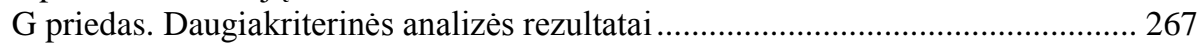

H priedas. Autorès sąžiningumo deklaracija........................................................... .274

I priedas. Bendraautorių sutikimai teikti publikacijose skelbtą medžiagą mokslo

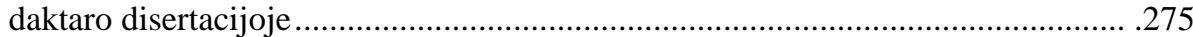

J priedas. Autorès mokslinių publikacijų disertacijos tema kopijos ....................... 277

${ }^{1}$ Priedai pateikiami pridètoje kompaktinèje plokštelèje. 



\section{Contents}

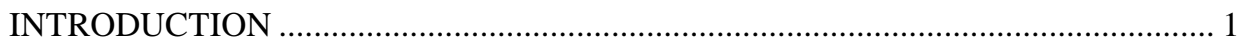

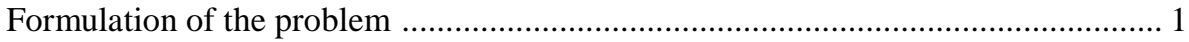

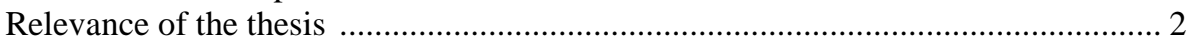

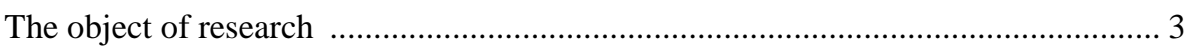

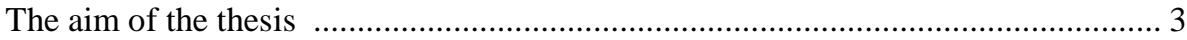

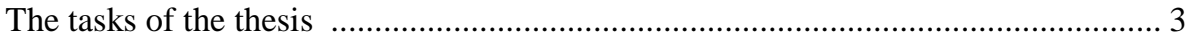

The research methodology ............................................................................... 4

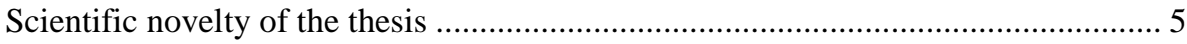

Practical value of the reasearch findings ............................................................. 5

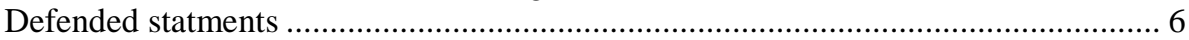

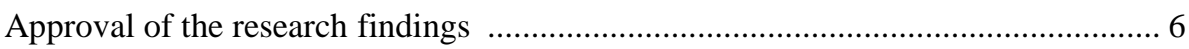

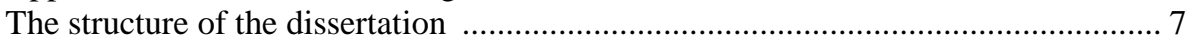

1. LANDSCAPE ARCHITECTURE - COMPLEX PART OF THE CITY

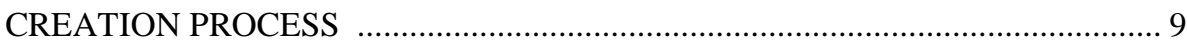

1.1. Evolution of the concept of landscape architecture ........................................ 10

1.2. Professional field of landscape architecture ................................................... 16

1.3. Expression of landscape architecture in urban processes of the 19-20th

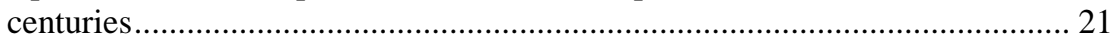

1.3.1. Development of the city and its green spaces at the turn of the 19th

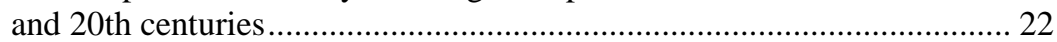

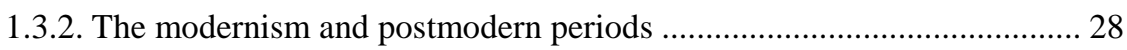


1.3.3. Theories and practices of modern landscape architecture and urbanism interaction

1.4.The research and applied methods of landscape-urban interaction .................... 40

1.4.1. The research topics and aspects............................................................ 40

1.4.2. The research methods for urban environment .......................................... 49

1.5. Conclusions of the first chapter and formulation of the thesis objectives ......... 55

2. FRAMEWORK OF RESEARCH OF INTERACTION BETWEEN LANDSCAPE

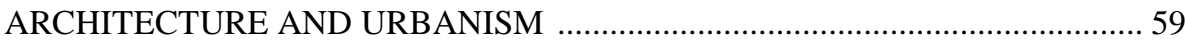

2.1. The interaction of landscape architecture and urbanism solutions in spatial planning 60

2.1.1. Solutions for urban master plans in the aspect of the development of the natural framework and green areas system

2.1.2. Master plans as a tool for optimizing the interaction between landscape architecture and urbanization solutions

2.2. The Experts opinion survey about the role of landscape architecture in the city creation

2.3. Designing the model of optimal interaction for landscape Architecture and urbanism solutions

2.3.1. The interaction of natural and anthropogenic structures as the basis of urban expression

2.3.2. The basic principles and provisions for optimal interaction ................... 90

2.3.3. Establishment of three-member research criterion system ..................... 95

2.3.4. Experimental research of the territory using the spatial grid method...... 99

2.4. Conclusions of the second chapter

\section{METHODOLOGICAL MODEL FOR OPTIMIZING THE INTERACTION OF}

LANDSCAPE ARCHITECTURE AND URBAN SOLUTIONS

3.1. Landscape Architecture principles to conceptualise the results of research for interaction

3.2. The application of methodological model at various territorial levels

3.3. The conditions for the scientific and practical application of the methodological model

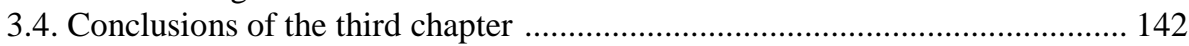

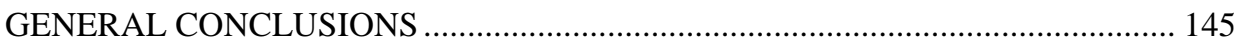

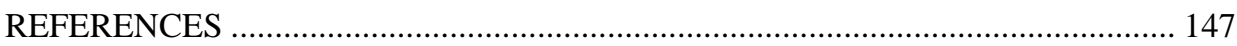

LIST OF SCIENTIFIC PUBLICATIONS THE AUTHOR ON THE TOPIC

OF THE DISSERTATION

SUMMARY IN ENGLISH. 
ANNEXES $^{2}$

Annex A. The table of the concept "landscape architecture"

development analysis

Annex B. The illustrations and summary tables of chapter II ............................... 178

Annex C. The illustrations and summary tables of chapter III............................... 206

Annex D. The experts survey questionnaires …………....................................... 212

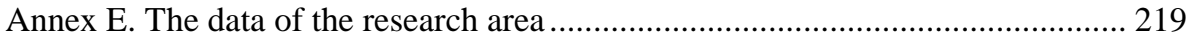

Annex F. The tables of evaluation results ........................................................ 230

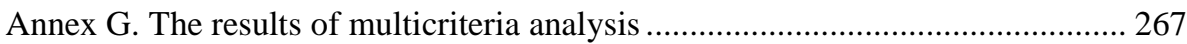

Annex H. Declaration of academic integrity ........................................................ 274

Annex I. The co-authors of the scientific publications agreements to present publications materials in the disertation ..................................................... 275

Annex J. Copies of scientific publications by author on the topic of the dissertation

${ }^{2}$ The annexes are supplied in the enclosed compact disc 



\section{Ivadas}

\section{Problemos formulavimas}

Pasaulio kultūrinès raidos patirtis rodo, kad miestai nuo pat jų kūrimosi pradžios ne tik sprende pastatų ir gatvių statybos užduotis, bet tuo pačiu ir ieškojo geriausio santykio su gamtine aplinka, prie jos prisitaikant, interpretuojant, įsiterpiant ị jos audini. Miesto ir gamtos santykio tyrimu problematika yra neatskiriama nuo kraštovaizdžių tyrimų problematikos bendrai, susijusios su tokiais šių dienų kraštovaizdžių bruožais, kaip spartūs pokyčiai ir didelis jų mastas, didèjantis kraštovaizdžių sudètingumas, fragmentiškumas tiek fizine, vizualine, ekologine prasme, tiek ir dèl besikertančių ne visada matomų socialinių, kultūrinių, ekonominių ir kitų interesų (Gražulevičiūtè-Vileniškè, 2016). Tačiau, kaip teigia James Corner (2006), vis dar gajus išlieka supratimas, kad kraštovaizdžio kūrimas tolygus gražiu pastoralinių vaizdų kūrimui, kad tai yra antipodas koroduojančiam modernaus miesto aplinkos ir socialiniam gyvenimui. Galvojama, kad kraštovaizdis yra kažkas paimta iš gamtos, svetimas miestui, neturintis nieko bendro su statybomis, technologijomis ir infrastruktūra. Pasak J. Corner, sąvokos kraštovaizdis ir urbanistika priskiriamos atskiroms profesijoms ar disciplinoms. Ginčijamasi dažniausiai ne tiek dẻl skirtingų kūrybinių priemonių ar idèjos, bet dèl didelès profesinès atskirties ir dèl ịtakos sferos (Corner 2006). 
Lietuvoje taip pat teoriniu lygmeniu ir profesinèje veikloje stokojama vieningos kraštovaizdžio architektūros esmès ir reikšmès sampratos. Tiek praktikoje, tiek moksle dar labai skirtingai traktuojamas kraštovaizdžio architektūros kompetencijų bei kūrybinès veiklos laukas. Diskutuojama dèl kūrèjo instrumentarijaus ir paties kūrybos objekto. Kartais abejojama dẻl meninès kokybės raiškos priemonių. Architektūra, urbanistika, kraštovaizdžio architektūra iki šiol nèra aiškiai ir sistemiškai suformulavusios savo konceptualių nuostatų bei apibrèžusios savo kompetencijų erdvès (Kavaliauskas 2013). Atskirties problema prasideda regiono ir miesto vystymosi strategijų nustatymo bei miesto planavimo lygmenyse, pereina ị kvartalo planavimo bei projektavimo lygmenis ir išlieka rengiant atskirų objektų projektus. Miesto vystymosi procesuose, laiku nepasitelkiant kraštovaizdžio architektūros kompetencijų, dažnai gamtinių ir urbanistinių struktūrų sąveikos problemos visiškai nesprendžiamos - formaliai vertinama esama situacija, vienpusiškai nustatomi prioritetai, neišnaudojama galimybe išsaugoti, racionaliai ir kūrybiškai panaudoti ir ị kuriamą aplinką integruoti gamtinius ir antropogeninius išteklius.

Pagrindinis tiriamas klausimas - kas lemia kraštovaizdžio architektūros ir urbanistikos sprendinių sąveiką, kokia šios sąveikos reikšmė tenkinant miesto ekologinius, socialinius bei estetinius poreikius ir kaip galima optimizuoti šią sąveiką sprendžiant gamtinių ir urbanistinių struktūrų dermès uždavinius?

\section{Darbo aktualumas}

Kraštovaizdžio architektūros ir urbanistikos profesinių veiklų sąveikos klausimo aktualumą lemia šiuolaikiniai miesto gyvenimo kokybės iššūkiai, reikalaujantys didesnès sinergijos tarp gamtinių ir urbanistinių sprendinių. Naują požiūrị ị urbanistinio planavimo ir projektavimo prioritetus padeda diegti ir Europos komisijos komunikatas (COM(2013) 249), „Žalioji infrastruktūra. Europos gamtinio kapitalo puoselejjimas", kuriame, be kita ko, teigiama, kad gamtos, jos procesų ir daugelio visuomenès naudojamų gamtinių gèrybių apsauga bei stiprinimas turi būti sąmoningai integruojami ị teritorijų planavimą ir plètrą (Europos komisija... 2013). 2016 m. pasirašytas Amsterdamo paktas, kuriuo nustatyta ES miestų darbotvarkè ir per JT konferenciją „Habitat III“ priimta Naujoji miestų darbotvarké (New Urban Agenda 2017), skatina urbanistinius uždavinius spręsti vadovaujantis tvarumo paradigma. Tai reiškia, kad daugelis ateities urbanistinių uždavinių bus betarpiškai susiję su gamtinių ir kultūrinių išteklių apsauga, bioịvairovès išsaugojimu ir gausinimu, alternatyvia energija, klimato kaitos problemomis, tvaraus vandens ciklo užtikrinimu, visuomenès dalyvavimu, aplinkos kokybès užtikrinimu ir t. t. XXI amžiuje urbanistikos mokslas ieško kelių, kaip integruoti ivvairių mokslo sričių metodus ir išvadas, ypač koncentruojantis ị kraštovaizdi ir 
jo valdymą, kaip alternatyvų būdą ir požiūrị sprendžiant tvaraus miesto klausimus, atsižvelgiant ị kraštovaizdžio teikiamų paslaugų gausą ir integralumą (Nassauer 2012). Šis darbas yra aktualus todèl, kad juo siekiama metodologiškai susieti mokslo tyrimus, kurie nagrinèja kraštovaizdžio ir urbanistikos problemas skirtingais aspektais ir skirtingose mokslo ir praktikos kryptyse.

\section{Tyrimų objektas}

Šio darbo tyrimo objektas yra kraštovaizdžio architektūros ir urbanistikos sprendinių sąveikos ypatumai bei kraštovaizdžio architektūros vaidmuo miesto vystymo procesuose. Disertacijoje tiriamos miesto teritorijos, o kaimo, žemès ūkio ir visiškai gamtinių teritorijų problematika paliekama už šio tyrimo ribų.

\section{Darbo tikslas}

Atskleidžiant kraštovaizdžio architektūros raidą ir vaidmenį mieste, sukurti tvaraus vystymosi principais paremtą kraštovaizdžio architektūros ir urbanistikos sprendinių sąveikos optimizavimo metodinį modelį.

\section{Darbo uždaviniai}

Darbo tikslui pasiekti darbe reikia spręsti šiuos uždavinius:

1. Išnagrinèti kraštovaizdžio architektūros raiškos urbanistiniuose procesuose ypatumus ir tendencijas nuo XIX a. vidurio iki mūsų dienų.

2. Ištirti kraštovaizdžio architektūros ir urbanistikos sprendinių sąveikos potencialą miesto teritorijų planavimo dokumentuose.

3. Atskleisti, kokị vaidmenị kraštovaizdžio architektūrai kuriant miestą skiria užsienio ir Lietuvos ekspertai.

4. Sudaryti tvarumo principais pagrịstą kraštovaizdžio architektūros ir urbanistikos sprendinių sąveikos tyrimo modeli ir ji pritaikyti pasirinktose Vilniaus miesto teritorijose.

5. Pateikti mokslines rekomendacijas dèl kraštovaizdžio architektūros ir urbanistikos sprendinių sąveikos tyrimo metodinio modelio taikymo principų ir sąlygų. 


\section{Tyrimų metodika}

Dèl tyrimo objekto daugiaplaniškumo, darbe taikomi kompleksiniai tyrimo metodai. Raidos tyrimas parodo kraštovaizdžio architektūros kūrybinio lauko pasauliniame kontekste augimą ir santykio su urbanistikos kūrybiniu lauku stiprèjimą, glaudejjančius profesinès veiklos aspektus bei sprendinių sąveikos tendencijas, kurių fone išryškèja susiklosčiusi sąveikos problematika Lietuvoje.

Bendrujų planų tyrimu siekiama Lietuvos mastu atskleisti kraštovaizdžio architektūros kūrybinio lauko potencialą, programuojamą BP sprendiniuose. Siekiant sužinoti kraštovaizdžio architektūros ir urbanistikos ekspertų nuomones dèl šių sričiu sąveikos ypatumų, buvo taikytas sociologinis ekspertų apklausos „Delphi“" metodas.

Autorès sudaryta trinarè ekologinių, socialinių ir estetinių kriterijų sistema, kuria vadovaujantis buvo atliekamas pasirinktos teritorijos vertinimas ir nustatomi tvarkymo prioritetai. Estetinių verčių nustatymui pritaikomas estetinio poveikio metodas (angl. method aesthetical perception) (Kaplan\&Kaplan 1989; Stamps III 2004). Nustatant kriteriju prioritetus naudojamas vienas iš daugiakriterinès analizès metodu (MCDM, angl. multi criteria decision making), vadinamasis AHP (angl. analytic hierarchy process), kuris yra populiarus ir sékmingai taikomas planavime, aplinkosaugoje, kraštovaizdžio architektūroje, sprendžiant klimato kaitos problemas ir kt. (Lifang, Yichuan, Wei 2008). Rekomendacijos dèl tyrimo metu teritorijoje nustatytu prioritetinių kriterijų ir uždavinių igyvendinimo teikiamos pasitelkiant kraštovaizdžio architektūroje taikomus daugiasluoksnès analizès, procesiškumo, erdvių sekvenavimo ir konteksto principus (Marot 1995; Jauslin 2010). Pagrindiniai miestą formuojantys gamtiniai elementai - reljefas, vandens telkiniai ir augalija - analizuojami santykyje su miesto struktūros suvokimo elementais - keliais (angl. paths), mazgais (angl. nodes), ribomis (angl. edges), vietoženkliais (angl. landmarks), kvartalais (angl. districts), pritaikantt pastaruoju metu vis dažniau naudojamą kraštovaizdžio architektūros tyrimuose Kevin Lynch urbanistinès analizės metodą (Lynch 1960; Bchir Jaber 2013). Tyrimo pagrindui naudojama ortofoto medžiaga ir kiti GIS duomenys. Teritorija vientisai padengiama $1 \mathrm{kv}$. km dydžio gardele, kuri atitinka kvartalų grupès lygmens skaidymą. Tokio dydžio etaloninès gardelès metodas yra taikomas Europos kraštovaizdžio monitoringo sistemose (Veteikis et al. 2015). Išsamesnei analizei stambesniu masteliu etaloninė $1 \mathrm{kv}$. km dydžio gardelè skaidoma iki mažesnio vieneto $-500 \times 500 \mathrm{~m}$ dydžio subgardelès, kuri labiau atitinka kvartalo lygmenị ir kurioje geriau išryškèja būdingi vienalyčiai urbanistinių ir gamtinių elementų fizinès sąveikos bruožai. Duomenų ir lentelių apdorojimui naudojamas „Microsoft Excel“ programinis paketas, AHP skaičiuoklè, ArcGIS. 


\section{Darbo mokslinis naujumas}

Disertacijoje pasiekti šie nauji moksliniai rezultatai:

1. Kraštovaizdžio architektūros ir urbanistikos sprendinių sąveikos tyrimas moksliniu požiūriu yra naujas dalykas.

2. Šiuo moksliniu darbu sukuriamos metodologinès prielaidos efektyviau naudoti miesto tvarkymui ir jo plètotei reikalingas kraštovaizdžio architektūros srities kompetencijas ir savalaikę jų sinergiją su urbanistiniais ir architektūriniais uždaviniais.

3. Sukurtas naujas integralus sąveikos tyrimo modelis, kurio esmę sudaro trinarè tolygi ekologinių, socialinių ir estetinių kriterijų vertinimo sistema. Ta pati kriterijų sistema taikoma teritorijos vertinimui, planavimo bei projektavimo prioritetų bei tvarkymo principų nustatymui.

4. Sąveikos tyrimo modelyje atskleistos naujos gardelès metodo taikymo galimybès - metodiškai nustatomas nagrinèjamos teritorijos dydis. Gardelès metodas taip pat sudaro prielaidas specifinių teritorijos duomenų, nustatytų taikant ši naują metodinị modelį, kodavimui ir integravimui $\mathfrak{i}$ GIS duomenų sistemą.

\section{Darbo rezultatų praktinè reikšmè}

Darbo rezultatai yra aktualūs visiems miesto kūrimo proceso dalyviams, ypač ruošiant miestų vystymo strategijas, programas ir darbų užduotis atskirų miesto teritorijų kompleksiniam tvarkymui, ieškant racionalių sprendimų naujos urbanistinès struktūros kūrimui ar esamos pertvarkymui, sprendžiant miesto kraštovaizdžio tvarkymo klausimus. Sukurtas metodinis modelis yra priemonė nustatyti kraštovaizdžio architektūros ir urbanistikos profesinių veiklų bei sprendinių optimalios sąveikos gaires, numatyti socialinių poreikių sinergiją esamame ir kuriamame kraštovaizdyje. Šiuo metodiniu modeliu skatinama taupiai ir kūrybiškai naudoti gamtinius ir antropogeninius teritorijos išteklius, sudaromos prielaidos bendruomenei dalyvauti miesto vystymo procesuose. Darbo rezultatai sustiprina kraštovaizdžio architekto profesijos ir kompetencijų reikšmę miesto planavime, urbanistiniame ir architektūriniame projektavime. Sukurtas kraštovaizdžio architektūros ir urbanistikos sprendinių optimizavimo metodinis modelis gali būti taikomas savivaldybèse bei privačiose kompanijose, norint išsiaiškinti teritorijoje esančių gamtinių ir antropogeninių išteklių ypatumus ir jų kūrybiško panaudojimo bei pritaikymo galimybes. Metodinis modelis gali būti naudojamas ir miesto aplinkos kokybės stebėsenos procese. 


\section{Ginamieji teiginiai}

1. Visi urbanistiniai procesai vyksta kraštovaizdžio kontekste ir yra neišvengiamai susiję su gamtiniu pagrindu, todèl miesto gaivinimo ir vystymo klausimai turi būti sprendžiami nagrinëjant gamtinių ir antropogeninių procesų sąveikos ypatumus. Kadangi kraštovaizdžio architektūra, pagal jos sričiai priskiriamas kompetencijas, sprendžia statinių ir jų kompleksų dermès su gamtine aplinka klausimus, todèl kiekvienas urbanistinis ar architektūrinis reiškinys, susijęs su gamtiniu pagrindu ar atskirais gamtiniais elementais, nuo pat jo kūrimo pradžios yra potencialus kraštovaizdžio architektūros kūrybinès veiklos objektas.

2. Kraštovaizdžio architektūros ir urbanistikos sprendiniai nuolat sąveikauja. Šios sąveikos pobūdis priklauso nuo tuo metu dominuojančios miesto vystymo paradigmos, proceso dalyvių etikos ir kompetencijų. Šiandienos tvaraus miesto kūrimo strategija, profesinè etika, kūrybos principai ir uždaviniai suponuoja kraštovaizdžio architektūros ir urbanistikos sprendinių optimalios sąveikos kriterijus, pagal kuriuos gali būti nustatomi savalaikiai kraštovaizdžio apsaugos ir tvarkymo prioritetai, racionaliai saugomi ir optimaliai naudojami bei žmonių poreikiams kūrybiškai pritaikomi gamtiniai ir antropogeniniai ištekliai.

3. Tvari urbanistika neįmanoma be kraštovaizdžio architektūros sprendinių. Taikant kraštovaizdžio architektūros tyrimo principus, kūrybos metodus ir jų igyvendinimo priemones miesto ekologiniai, estetiniai ir socialiniai poreikiai optimaliai suderinami ir sprendžiami sujungiant juos i vientisą tvarią, veikiančią laike, sistemą.

\section{Darbo rezultatų aprobavimas}

Disertacijos tema atspausdinti 8 moksliniai straipsniai: vienas - mokslo žurnale, referuojamame SCOPUS tarptautinèje duomenų bazèje (Deveikiené 2018b); vienas - mokslo darbų leidinyje, referuojamame Index COPERNICUS ir SIS tarptautinėse duomenų bazèse (Deveikienè 2018a), du - mokslo žurnale, referuojamame ICONDA ir Index COPERNICUS tarptautinèse duomenų bazèse (Deveikienė 2016; 2015), vienas - referuojamame EBSCO, CSA/ProQuest duomenų bazejje (Stauskis, Deveikienè 2016); du - recenzuojamoje tarptautinių konferencijų medžiagoje (Deveikienė 2016; Deveikiené, Deveikis 2017), vienas recenzuojamame mokslo darbų leidinyje (Deveikienè, Stauskis 2017).

Disertacijoje atliktų tyrimų rezultatai buvo paskelbti septyniose mokslinėse konferencijose Lietuvoje ir užsienyje: 
- Jaunujų mokslininkų konferencijoje „Mokslas - Lietuvos ateitis. K. Šešelgio skaitymai“ 2015 m. Vilniuje ir 2016 m. Rokiškyje.

- Lietuvos kraštovaizdžio architektūros forume „Kraštovaizdžio architektūra-profesijos horizontai ir sinergija " $2015 \mathrm{~m}$. Vilniuje.

- Jaunujų mokslininkų konferencijoje „Mokslas - Lietuvos ateitis. Aplinkos apsaugos inžinerija“ 2016 m. Vilniuje.

- Tarptautineje konferencijoje ,Surveying the world of tomorrow - from digitalisation to augmented reality" $2017 \mathrm{~m}$. Helsinkyje (Suomija).

- Tarptautinejje konferencijoje „7e Journées doctorales en paysage“ 2018 m. Versalyje (Prancūzija).

- Konferencijoje „Kraštovaizdžio architektūra Baltijos šalyse - šimtmečio retrospektyva ir ateities perspektyvos" $2018 \mathrm{~m}$. Kaune.

\section{Disertacijos struktūra}

Disertaciją sudaro ịvadas, trys skyriai, naudotos literatūros ir autorès publikacijų disertacijos tema sąrašai. Darbo apimtis - 175 puslapiai teksto, neskaitant priedų. Pagrindinèje darbo dalyje pateikiama 34 paveikslai ir 15 lentelių. Rengiant disertaciją buvo naudoti 183 šaltiniai. 



\section{1}

\section{Kraštovaizdžio architektūra - sudètinè miesto kūrimo proceso dalis}

Skyriaus tikslas - aptarti tik pačias svarbiausias ir reikšmingiausias moderniojo miesto sampratas ir miesto santykio su gamta, gyvojo, tvaraus miesto kraštovaizdžio formavimo problematiką. Svarbiausi uždaviniai būtų: apibrèžti miesto, kaip architekto, urbanisto ir kraštovaizdžio architekto veiklos objekto, sampratą, išnagrinèti želdynų ir kitų gamtinių elementų urbanistinèje aplinkoje svarbą ir šios svarbos kaitą, nustatyti kraštovaizdžio formavimo potencialą ir sinergijos gaires. Aprèpiamas moderniojo miesto laikotarpis - nuo XIX a. antrosios pusès iki šių dienų. Skyriaus medžiaga ir kraštovaizdžio architektūros ir urbanistikos sąveikos raidos tyrimų rezultatai pristatyti šiose autorès publikacijose (Deveikienė 2015; Deveikienè 2016; Stauskis, Deveikienė 2016).

\subsection{Kraštovaizdžio architektūros sampratos raida}

Kraštovaizdžio architektūros pirmtake laikoma visų istorinių laikų dekoratyvinė sodininkystè, kurios raida plačiai nagrinejjama kaip sodų ir parkų menas. Vokiečiai palyginti visai neseniai šią sritị vadino sodų architektūra (vok. Gartenarchi- 
tektur), anglai - kraštovaizdžio sodininkyste (angl. landscape gardening), prancūzai - sodo menu (pranc. l'art de jardin) (Pilkauskas 2004). Kraštovaizdžio architekto profesija ịvairiose šalyse patyrè skirtingą raidą. Jos tikslai, veikimo įrankiai ir kūrybinè medžiaga bei veiklos laukas nuolat kito ir skirtingose šalyse vystèsi skirtingai.

Konstantinas Jakovlevas-Mateckis atkreipia dėmesi i ǐinomo kraštovaizdžio architektūros teoretiko A. Bohm mintị, kad „kraštovaizdžio architektūra turi tokią pat ilgą istoriją kaip ir kultūra“ (Bohm 1994; Jakovlevas-Mateckis 2008). Dalis Lietuvos mokslininkų (Pilkauskas 2004; Jakovlevas-Mateckis 2008) iki šiol laikosi nuomonès, kad kraštovaizdžio architektūros terminą pirmą kartą apie 1860 m. pavartojo žymus JAV parkų kūrèjas Frederick Low Olmsted (18221903) su bendradarbiais. Tai iš esmès yra tiesa, tačiau naujausi moksliniai tyrimai rodo tam tikrą ankstyvesnę „kraštovaizdžio architektūros“ arba „kraštovaizdžio architekto" termino raidą (A priedas, A1 lentelè).

Kaip teigia Kolumbijos universiteto (JAV) profesorius Joseph Disponzio, kraštovaizdžio architekto profesijos pavadinimas anglų kalba landscape architect ir susijęs veiklos srities pavadinimas landscape architecture yra tikètinai kilę iš prancūziško profesijos termino architecte-paysagiste, kurị pirmą kartą pavartojo Jean-Marie Morel XIX a. pradžioje (Disponzio 2014).

Prancūzų architektas, inžinierius ir sodų projektuotojas Jean-Marie Morel (1728-1810) buvo ịvardijamas kaip ,architektas-peizažistas“ (pranc. architectepaysagiste). Savo kūryboje ir sodininkystès mene jis propagavo angliškajj̣ stilių. Jo nekrologe, kuris plačiai pasklido po Prancūziją, J.-M. Morel buvo ịvardintas kaip architecte-paysagiste (Waldhaim 2014). Pasak J. Disponzio, J.-M. Morel sukūrè terminą architecte-paysagiste todèl, kad norejjo atskirti naujai kylančios kraštovaizdžio tipologijos - angliškojo arba tapybiško (angl. picturesque) sodo kūrèją nuo tradicinio reguliaraus arba simetrinio, geometrinio sodo projektuotojo, stipriai susieto su André Le Nôtre ịvaizdžiu (Disponzio 2014). Šis sukomponuotas terminas pirmą kartą pasirodė 1803-1804 m. leidinyje „Liono miesto almanachas" (pranc. Almanach de la ville de Lyon), kuriame J.-M. Morel save pristate kaip „kraštovaizdžio architektą“ (pranc. architecte paysagiste). Apie 1850 m. J.-M. Morel ịdiegtą terminą architecte paysagiste pradeda vartoti ir Paryžiaus kraštovaizdžio projektuotojas Louis-Sulpice Varé (1803-1883), šiuo profesiniu vardu $1854 \mathrm{~m}$. pasirašydamas ant Bulonès miško parko (pranc. Bois de Boulogne) projekto. Oficialiai profesija arba šio projektuotojo užimamos pareigos įvardintos Senos departamento (Paryžius) administraciniame almanache, kuriame nuo 1853 m. L.-S. Varé buvo įrašytas kaip dirbantis kraštovaizdžio architekto pozicijoje (Disponzio 2014).

Dar svaresnis profesinio vardo ịtvirtinimas Prancūzijoje ịvyko, kai žymus parkų kūrèjas Edouard André (1840-1911) antrojoje XIX amžiaus pusèje save pristate kaip kraštovaizdžio architektą tituliniame savo 1879 m. leidinio „L'art 
des Jardins“ puslapyje (Disponzio 2014). Kraštovaizdžio architekto profesijos pavadinimas galutinai sutvirtintas ir pati profesija aprašyta $1886 \mathrm{~m}$. Armand Péan publikuotoje knygoje „Kraštovaizdžio architektas: parkų ir sodų kūrybos teorija ir praktika[...]" (pranc. L'architecte paysagiste: théorie et pratique de la création et décoration des parcs et jardins [...]) (Disponzio 2014).

Suporuoti žodžiai „kraštovaizdis“ (angl. landscape) ir „architektūra“ (angl. architecture) pirmą kartą Anglijoje pasirodo $1828 \mathrm{~m}$. Gilbert Laing Meason knygos pavadinime Landscape Architecture of the Great Painters of Italy. Tačiau tai yra sietina su architektūra Italijos peizažo tapyboje, bet ne su profesiniais tikslais. Angliškas terminas landscape architecture taip, kaip ji suprantame šiandien, pirmą kartą pavartotas 1840 m., kai kraštovaizdžio sodininkas (angl. landscape gardener) John Claudius Loudon (1783-1843) išleido savo draugo ir mokytojo Humphry Repton (1752-1818) išsamią raštu antologiją, kuriai suteikè neiprastą pavadinimą The Landscape Gardening and Landscape Architecture of the Late Humphry Repton, Esq. (liet. „Vèlyvoji Humphry Repton kraštovaizdžio sodininkystè ir kraštovaizdžio architektūra") (Davis et al. 2014). H. Reptonas nesukūrè naujos mados, bet ịtvirtino komercinę kraštovaizdžio architekto praktiką. Būdamas talentingu menininku, $\mathrm{H}$. Reptonas išvystė išradingą kuriamo vaizdo pateikimą ,prieš“ ir „po“ (angl. before-and-after drawings), kitaip dar vadinamą Raudonaja knyga (angl. Red Books), kur jis kaupdavo savo kūrinius. H. Reptono piešiniuose (projektuose) kraštovaizdis buvo išreikštas per dviejų dedamuju - pastato ir sodo ryši (angl. dyadic relation of house and garden). Naujos disciplinos kūrèjo veiklai suteiktas kraštovaizdžio architektūros pavadinimas išplaukia iš sodininkystės ir statybos sąvokų, nes ši sinergiška veikla nusipelno turèti jai skirtą pavadinimą. Kraštovaizdžio architektūros sąvokos ịvardijimas buvo panegirika $\mathrm{H}$. Reptonui ir tuo pačiu naujos meno rūšies krikštas (Davis et al. 2014). Šios meno rūšies praktikas buvo Andrew Jackson Downing (1815-1852), kuris $1841 \mathrm{~m}$. parašè veikalą apie kraštovaizdžio sodininkystès teoriją ir praktiką (angl. Treatise on the Theory and Practice of Landscape Gardening). A. J. Downing teigè, kad architektūros grožis turi būti suvokiamas bendrai su kraštovaizdžiu ar kita aplinka (Davis et al. 2014). Kraštovaizdis ir architektūra, jo supratimu, buvo tvirtai sujungti, bet šis ryšys buvo suvokiamas daugiau per gretimumą (angl. adjacency) negu per giminingumą (angl. affinity) (Davis et al. 2014). J. C. Loudono sugalvota kraštovaizdžio architektūros sąvoka nebuvo ,pasigauta“ iki 1860 m., kai Frederick Law Olmsted (1822-1903) ir Calvert Vaux (1824-1895), kurdami Centrinị parką Niujorke, save ịvardino kraštovaizdžio architektais (angl. landscape architects). Būtent čia terminas „kraštovaizdžio architektas“ igauna reikšmingą prasmès pokytį. F. L. Olmstedas niekada anksčiau nesidomėjo pastatų ir sklypų projektavimu, tad sąvokos ,,architektas" pavartojimas jam buvo ne tiek žodinis veiklos įvardinimas, kiek profesiné strategija pasinaudoti architektūros prestižu ir kelti savo darbo kainą. (Davis 
et al. 2014). Tikètina, kad F. L. Olmstedas profesijos pavadinimą nusižiūrèjo iš Prancūzijos kolegu prancūziško varianto architecte paysagiste, $1859 \mathrm{~m}$. būdamas Paryžiuje. Manoma, kad susitikimo su Paryžiaus žaliujų erdvių pertvarkymo vadovu inžinieriumi J.-Ch. A. Alphand (1817-1891) metu, jis lankèsi Bulonès miške ir matė L. S. Varé sukurtą Bulonès miško parko sutvarkymo projektą, kurị autorius buvo pasirašęs save ịvardindamas kraštovaizdžio architektu. Šio parko pertvarkymo ịspūdžiai vèliau turèjo didelę įtaką Centrinio parko Niujorke sukūrimo (1857-1860) idejjai (Disponzio 2014). Nors parengta daug Centrinio parko vystymo brèžinių $(1858,1860,1866,1867,1870 \mathrm{~m}$. ir t. t.), bet ant jų konkrečiai nèra nurodyta autorių profesija. Tačiau tuo pat metu Olmstedo ir Veaux kompanija kūre kitus objektus, kur jau tituliniuose lapuose aiškiai matome irrašus - „Prospect park“ projekto autoriai „Olmsted Vaux \& Co. Landscape architects. 1866-1867“; „Riverside“ projekto autoriai „Olmsted Vaux \& Co. Landscape architects. 1869“. Kaip teigia mokslininkai Brian Davis ir Thomas Oles,

F. L. Olmstedas $1886 \mathrm{~m}$ laiške savo kolegai Charles Eliot aiškino savo mintis dèl profesijos pavadinimo: „mums reikètų save vadinti kraštovaizdžio architektais [...], o ne kraštovaizdžio sodininkais [...], nes naujasis pavadinimas labiau atskleidžia profesinę idejją“" (Davis et al. 2014). Kraštovaizdžio architekto profesija JAV buvo ịtvirtinta $1899 \mathrm{~m}$. ịkuriant Amerikos kraštovaizdžio architektų asociaciją (angl. American Society of Landscape Architects, ASLA). Vienas pagrindinių šios profesinès asociacijos steigèjų buvo F. L. Olmstedo sūnus, kraštovaizdžio architektas F. L. Olmstedas jaunesnysis (Frederick Low Olmsted Jr. (1870-1957)).

Vokietijoje kraštovaizdžio architekto profesijos raida klostėsi panašiai kaip ir kitose šalyse - nuo dvarų ir pilių parkų bei sodų projektų iki viešųjų visuomenei sveikatinti skirtu parkų. 1913 m. Frankfurte prie Maino buvo ịkurta Vokietijos sodų architektų asociacija (vok. Bund Deutscher Gartenarchitekten), kuri $1972 \mathrm{~m}$. buvo pervadinta ị Vokietijos kraštovaizdžio architektų asociaciją (vok. Bund Deutscher Landschaftsarchitekten, BDLA). 1968 m. Tarptautinè darbo organizacija (angl. ILO - International Labour Organization) Ženevoje oficialiai pripažino kraštovaizdžio architekto profesiją ir kvalifikavo ją kaip atskirą ir savarankišką greta pastatų architekto (angl. Building Architect) ir urbanisto (angl. Town Planner). Apibendrinta kraštovaizdžio architektūros sąvokos sampratos ir sąvokos vartojimo raida pateikiama A priedo 1 lenteleje.

Lietuvos kraštovaizdžio architektūros raidą yra išsamiai aptaręs Regimantas Pilkauskas (2004). Jis Lietuvos kraštovaizdžio architektūros užuomazgas sieja su senuoju Vilniaus universitetu ir jo auklètiniais Juozapu Strumila (1774-1847) ir Karoliu Podčašinskiu (1790-1860). J. Strumilos „Šiaurès sodai“ (Ogrody polnocne, pirmoji laida 1820; vèliau išleistos 7 laidos) ir K. Podčašinskio tekstai „Bendrujų tobulumo principų taikymas paveikslų ir skulptūrų amato kūriniams 
bei puošniems sodams ir parkams kurti“ (1838) ir „Architektūros pradmenys akademiniam jaunimui““ (1856) ilgam paliko kultūrinị ir meninị pėdsaką ir darè ịtaką Lietuvos, Lenkijos, Baltarusijos dvarų parkų kūrejjams (Pilkauskas 2004). Nors Lietuvoje darbavosi save kraštovaizdžio architektais įvardinantys parkų kūrejjai, kaip Edouard François André (1840-1911), René André (1867-1942) ir Georg Friedrich Ferdinand Kuphaldt (1853-1938), tačiau profesinis kraštovaizdžio architektūros terminas mūsų šalyje dar ilgai nebuvo vartojamas. Jeigu palygintume XX a. tarpukario Lietuvos ir Latvijos kraštovaizdžio architektūros tradicijas, tektų pripažinti, kad Latvijos kraštovaizdžio architektūros tradicija yra stipresnè ir gilesnè, ateinanti, perimta ir tęsiama iš Rygos kraštovaizdžio architekto, vokiečio, Potsdamo ir Dahlemo mokyklų atstovo G. Kuphaldto, jo mokinio Andrejaus Zeidako (1874-1964) ir pastarojo mokinio Karl Barons (19121996) aukštos miestų (ypač Rygos) želdynų kultūros tradicijų.

Kaip teigia R. Pilkauskas, „XIX a. ir XX a. sandūroje padedama užsienio specialistų Lietuva sukūrẻ daug aukšto meninio lygio parkų. Greta profesionaliosios želdynų kūrybos, Lietuvoje nuo seno gyvavo ir valstiečių sodybų tvarkymo tradicija, panašiai kaip medinè architektūra ir skulptūra. Po Pirmojo pasaulinio karo Lietuvai atkūrus valstybės nepriklausomybę, būta gerų dvasinių pagrindų plètoti savo kultūrą" (Pilkauskas 2004). 1921 m. ịkurta Lietuvai pagražinti draugija. Miestų savivaldybėse pradejjo veikti sodininkystės skyriai, kurie profesionaliai rūpinosi parkais ir sodais arba, kaip dabar sakoma, miesto želdynais (Pilkauskas 2004). R. Pilkauskas pažymi, kad „1935 m., ką tik baigęs Paryžiaus aukštają meno mokyklą (pranc. École régionale supérieure des BeauxArts), iš Prancūzijos sugrịžo architektas Jonas Kovalskis-Kova (1906-1977). Jis buvo pasirengęs planuoti teritorijas ir savo pasirengimą greitai įrode - suplanavo Kauno Azžuolyną, kurio projektas rodo, kad Lietuvoje atsirado ne tik miestų planuotojas, bet ir mokytas kraštovaizdžio architektas“ (Pilkauskas 2004).

1939-1944 m. Kauno taikomosios dailès institute pradètos želdynu projektavimo studijos. Jau mineta, kad joms vadovavo doc. J. Kovalskis (Pilkauskas 2004). Jis paliko ir mokinių, ir dėstymo tradiciją, kuri buvo tęsiama Kauno politechnikos institute (dabar KTU), o vèliau ir Vilniaus inžineriniame statybos institute (dabar VGTU) Urbanistikos katedrose, tačiau kraštovaizdžio architekto kvalifikacija nebuvo suteikiama. Kraštovaizdžio architektūros studijas atitinkanti programa nuo $1972 \mathrm{~m}$. buvo dèstoma Valstybiniame Dailès institute (dabartiné Vilniaus dailès akademija). Nuo $1991 \mathrm{~m}$. kraštovaizdžio architektūros studijos vykdomos Klaipėdos universitete (Grecevičius et al. 2010).

Savo monografijoje „Miesto kraštovaizdžio architektūra“ K. JakovlevasMateckis teigia, kad architektai, kraštovaizdžio architektai ir kai kurie geografai, pvz., K. Šešelgis (1972 m.), K. Jakovlevas-Mateckis (1972 m.), G. Daniulaitis (1973 m.), P. Kavaliauskas (1973 m.), A. Tauras (1974 m.), terminus „landšaftas" ir „kraštovaizdis“ vartojo kaip sinonimus. Jais buvo ịvardijama gamtinių ir 
antropogeninių komponentų visuma (Jakovlevas-Mateckis 2008). Remiantis informacija iš P. Kavaliausko mokslinès-projektinès-pedagoginès veiklos ir meninès kūrybos bibliografinio sąvado (2015), P. Kavaliaukas ir G. Daniulaitis 1974-1975 m. yra parengę straipsnių apie kraštovaizdžio architektūrą žurnaluose „Mokslas ir gyvenimas“ (1974) ir „Statyba ir architektūra“ (1975). 1974 m. Lietuvos architektų sajungoje buvo ịkurta Kraštovaizdžio architektūros komisija, o 1987 m. ji performuota ị Kraštovaizdžio architektūros sekciją Lietuvos architektų sajungos sudètyje (Stauskas 2010). 1995 m. buvo įkurta savarankiška Lietuvos kraštovaizdžio architektų sajunga. Kraštovaizdžio architekto veikla klasifikuojama kaip savarankiška profesija naujajame Tarptautinès darbo organizacijos patvirtintame Tarptautiniame profesijų klasifikavimo standarte ISCO-08 (angl. International Standard Classification of Occupations) bei nacionaliniame jo atitikmenyje - Lietuvos profesijų klasifikatoriuje 2012 (LPK 2012). Čia kraštovaizdžio architektas klasifikuojamas specialistų pagrindinèje grupejje (2), fizinių mokslų ir inžinerijos specialistų pogrupyje (21), architektų, planuotojų, topografų ir dizainerių grupejje (216), kraštovaizdžio architektų pogrupyje (2162), greta statybos architektų (2161) ir dizainerių (2163) pogrupių (LPK 2012).

Tačiau diskusijos dèl kraštovaizdžio architektūros sampratos tebevyksta. Algio Vyšniūno teigimu, ,yra dar viena labai komplikuota veiklos sritis, kur vartojama ypač paini terminija. Kalbu apie kraštovaizdị, kurio samprata „plaukioja“ tarp krašto vaizdo / kraštotvarkos / landšafto ir t. t. Todèl reikia atsakyti - kalbame apie krašto vaizdą ar landšaftą? Tokia klausimo formuluote susijusi su bendra kraštovaizdžio ir ypač kraštovaizdžio architektūros samprata, nes kartais darosi neaišku, ar tai, kas angliškai kalbančiose šalyse suprantama kaip landscape architecture, tikrai yra Lietuvoje vartojamo termino kraštovaizdžio architektūra atitikmuo? O gal kraštovaizdis yra tiesiog gamtovaizdis, kuris angliškai taip pat vadinamas landscape?" (Vyšniūnas 2013). Rekreacinių funkcijų raišką mieste nagrinėjanti Inga Urbonaitè pažymi, kad, kai kurių mokslininkų nuomone, miesto ribose tikslingiau vartoti „miestovaizdžio“ sąvoką, kuri apibrěžia kompleksišką ir sistemingą miesto vaizdo (peizažo) formavimą. Vis dèlto, plačiau vartojama ir bendru sutarimu daugiausia sutinkama miesto kraštovaizdžio sąvoka (Urbonaite 2013).

Europos kraštovaizdžio konvencijoje (2000) pateiktos sąvokų apibrěžtys padeda vieningai ir šiuolaikiškai traktuoti kraštovaizdžio sampratą îvairiomis kalbomis (angl. Landscape; pranc. Paysage), kuri evoliucionavo nuo XIX a. pradžioje pavartoto žodžio landscape. Pagal Europos kraštovaizdžio konvenciją, kraštovaizdis - tai žmonių suvokiama vietovè, kurios pobūdị nulèmé gamtos ir (arba) žmonijos veiksnių veikimas ir sąveika (Europos... 2000). Lietuvos Respublikos kraštovaizdžio politikos krypčių apraše, kuris yra parengtas Europos konvencijos pagrindu, pateikiamas kraštovaizdžio apibrèžimas yra labai artimas 
pateikiamam konvencijoje, tačiau žodžių junginys ,gamtos ir (arba) žmonijos veiksnių veikimas“ pakeistas junginiu ,gamtiniai ir (ar) antropogeniniai veiksniai“: kraštovaizdis - tai žmonių suvokiama vietovè (teritorija), kurios pobūdị nulèmé gamtiniai ir (ar) antropogeniniai veiksniai ir jų sąveika (Lietuvos Respublikos kraštovaizdžio politikos... 2004).

Disciplinų prieštarų grupejje pirmiausia būtų tikslinga aiškiai skirti kraštovaizdžio projektavimo ir kraštovaizdžio planavimo sferas. Pasak P. Kavaliausko, tai netgi galètų būti skiriamoji architektūrinių ir geografinių kraštovaizdžio pažinimo bei veiklos interesų linija. Kraštovaizdžio architektūros objektu laikytina kraštovaizdžio erdvinė išraiška, o tikslas - estetiškai šią išraišką sutvarkyti. Taigi kraštovaizdžio architektūra, pagal klasikinę anglosaksų sampratą, savo prigimtimi yra išorinių (atvirų) erdvių (angl. outdoor spaces) formavimo menas, kurio uždavinys yra suteikti gamtinėms ir technogeninėms kraštovaizdžio morfostruktūroms išbaigtą psichologiškai priimtiną vietos erdvinę išraišką. Taip formuluojama architektūrinè paradigma galètų atstovauti kraštovaizdžio percepcinio pažinimo bei formavimo nuostatoms (Kavaliauskas 2013). Britų autoriai teigia, kad kraštovaizdžio architektūra, kaip profesinè veikla ir akademinis dalykas, aprèpia kraštovaizdžio planavimą, projektavimą ir tvarkymą. Taip formuluojama paradigma suteikia erdvès pilnavertei kraštovaizdžio, jo formavimo, tuo pačiu analizès ir vertinimo, sampratai. Teoriniuose darbuose nuolat teigiama, kad kraštovaizdžio formavimas yra daugialype ir sudètinga visuomenès veiklos sfera, tarpdalykinių studijų, meninio ir mokslinio pažinimo krypčių konkurencijos objektas (Kavaliauskas 2013).

Kraštovaizdžio architektūros sąvoka Lietuvoje oficialiai yra apibrèžta tik Lietuvos Respublikos kraštovaizdžio politikos apraše kaip taikomoji mokslo ir meno disciplina, formuojanti žmogaus erdvinę aplinką: statinių ir jų kompleksų dermę su kraštovaizdžio gamtiniu pagrindu ar jo atskirais elementais (Lietuvos Respublikos kraštovaizdžio politikos... 2004).

Tačiau ịvairiuose mokslo darbuose dar yra bandoma rasti naujus ar tobulinti esamus apibrež̌imus. Tai yra visiškai suprantama, nes sąlyginai jauna profesija evoliucionuoja ir jos pokyčius įdomu nagrinèti ir apie juos diskutuoti tiek praktikams, tiek mokslininkams. Dèl tarpdisciplininio pobūdžio kraštovaizdžio architektūros sampratą nagrinėja skirtingų profesijų mokslininkai.

Šio darbo autorei yra priimtinas oficialus kraštovaizdžio architektūros apibrèžimas, ịtvirtintas Lietuvos Respublikos kraštovaizdžio politikos apraše, nes jis pakankamai gerai ir glaustai atspindi kraštovaizdžio architektūros misiją tiek miesto, tiek kaimiškoje, tiek visiškai gamtinejje aplinkoje. Svarbesnis uždavinys yra apibrèžti kraštovaizdžio architektūrai būdingas kompetencijas, jos kūrybinès veiklos lauką, metodus ir prioritetus. 


\subsection{Kraštovaizdžio architektūros profesinès veiklos laukas}

Miestas yra žmogaus rankų ir minties kūrinys, socioekonominių, sociokultūrinių ir geoekologinių procesų vieta ir erdvè. Teoriniuose darbuose nuolat teigiama, kad miestas yra tarpdisciplininių studijų objektas ir miestovaizdžio formavimo veiklų sąveika yra neišvengiama (Urbonaitė 2012; Samalavičius 2013). Miesto kūrimas yra sudètinga ir daugialypè visuomenès veiklos sfera, kurioje persipina daugelio mokslinio ir meninio pažinimo krypčių interesai, joje vyksta šių krypčiu atstovų konkurencija pretenduojant ị lyderio ar pagrindinio veiklos organizatoriaus vaidmenị. Pasak P. Kavaliausko, architektūra, urbanistika, kraštovaizdžio architektūra iki šiol nèra aiškiai ir sistemiškai suformulavusios savo konceptualių nuostatų ir apibrěžusios savo kompetencijų erdvès. Jo teigimu „dažnai tebevyksta šių sričių oficialiųų ypač kraštovaizdžio architektūros, atstovų blaškymasis tarp meninès ir mokslinès, estetinès ir ekologinès, populistinès ir technokratinès ar kitokių ideologinių pakraipų ir paradigmų" (Kavaliauskas 2013).

Kraštovaizdžio architektūra - daugiadisciplininès veiklos baras, integruojantis architektūros, urbanistikos, teritorijų planavimo, žemès naudojimo, aplinkos estetikos ir psichoemocinio poveikio formavimo, aplinkos dizaino, botanikos (architektūrinès želdininkystės, architektūrinès dendrologijos), kraštovaizdžio ekologijos, hidrologijos, klimatologijos, dirvožemio mokslo ir kitus komponentus. Taigi, iš esmès jau kalbame apie ekologinio potencialo, aplinkos tvarumo, estetinès ir ekologinès kokybės dalykus. Šiuose sprendimuose reikalingos tampa urbanisto, aplinkos inžinieriaus, architekto, kraštovaizdžio architekto pastangos, jų veiklos loginis suderinimas ir sąveika. Tokios sąveikos pagrindas ir rezultatas turètų būti ekologinių, ekonominių, socialinių ir estetinių problemų sprendimo pasitelkiant tikslingus kraštovaizdžio formavimo sprendimus priemonè. Kaip teigia P. Juškevičius, ,teoriškai ịvairių sričių integracijos pradžia yra 1987 m., kai Gro Harlem Brundland komisija paskelbė darniosios plètros idèją“. Jos esmé - užtikrinti geresnę gyvenimo kokybę dabartinei bei būsimoms kartoms. Šiandien socialinès, ekonominès ir aplinkosauginès sričių integravimas grindžiamas gyvenimo kokybès sinerginiu efektu (Juškevičius 2005).

Prancūzų mokslininkai pastarajị dešimtmetį skiria nemažai dėmesio kraštovaizdžio architektų veiklos reikšmès kuriant tvarų ir ekologišką miestą tyrimams. F. A. Leger-Smith (2014) šiuos klausimus nagrinejjo savo daktaro disertacijoje „Kraštovaizdžio architektų darbų evoliucija sprendžiant urbanistinių koncepcijų ekologinius iššūkius" (pranc. Evolution des pratiques des paysagistes face aux enjeux écologiques de la conception urbaine). Ji teigia, kad posūkis ekologijos link tik sustiprina kraštovaizdžio architekto, kaip savo srities eksper- 
to, dalyvavimą urbanistiniame projekte. Taikant kraštovaizdžio architektūros požiūrị dar projekto pradžioje yra ịtvirtinami moksliniai ekologijos principai, kurių taikymui praktikoje pati kraštovaizdžio architektūra yra veiksminga priemonè. Kaip teigia Leger-Smith, kraštovaizdžio architektūros kelias savo esme yra priešingas reiškinys miesto formų homogeniškumui ir urbanistinejje koncepcijoje gina daugiadiscipliniškumą. Jos manymu, ekologija nèra kraštovaizdžio architektu veiklos evoliucijos faktorius, bet veikiau sudètinè kraštovaizdžio architektūros dalis, kuri apima aplinkos daugiafunkcionalumą, sistemiškumą, gyvastị, vietos atmintį, ilgalaikiškumą, dinamiką, žodžiu visa tai, kas sudaro kraštovaizdžio architekto darbą nuo šios profesijos atsiradimo pradžios (Leger-Smith 2014). Ekologinès vietovės savybès kraštovaizdžio architektus skatina prisitaikyti ir paịvairinti iki tol naudotą patirti. Jei kraštovaizdžio architektas gali išspręsti urbanistiniame projekte keliamus ekologinius iššūkius, tai logiška manyti, kad jis gali būti ir urbanistinio projekto lyderiu. Kai renkant komandą projektavimo darbams yra nustatomi ekologiniai kriterijai, atsiranda plačios galimybès kraštovaizdžio architektūros principų raiškai. Vienas iš kraštovaizdžio architekto uždavinių yra atskleisti priklausymo konkrečiai vietai jausmą. Jeigu globali ekologinè koncepcija kaip ir suvienodina miesto formas, tai ekologinius principus diegiant kraštovaizdžio architektūros priemonėmis, gaunamas ịvairovès efektas. Pavyzdžiui, vandens tvarkymo klausimas kraštovaizdžio architektūros projekte bus sprendžiamas visą laiką kitaip, priklausomai nuo vietos situacijos. Jeigu kraštovaizdžio architektas nori atlikti pagrindinị vaidmeni miesto ekologinèje koncepcijoje, jis turi būti ịvaldęs bendruosius metodus, išmanyti visas urbanistinio projekto sudètines dalis. Kyla klausimas dèl kraštovaizdžio architekto pasiruošimo dirbti ekologinio miesto projektavimo srityje, dèl statybinių klausimų išmanymo. Kraštovaizdžio architektai nėra pastatų architektai ir jie negali valdyti visų miesto planavimo ir projektavimo klausimų, tačiau labai svarbu, kad kraštovaizdžio architektas dar iki projekto pradžios padètų tinkamai suformuoti programą ir užsakymą (Leger-Smith 2014).

Kaip teigia K. Jakovlevas-Mateckis, ,per paskutinius dešimtmečius kraštovaizdžio architektūros objektų tematikos plotmé, ịvairovė ir jų apimtis labai išaugo“. Pasak jo, kraštovaizdžio architektai savo kūrybinèje veikloje dalyvauja keturių lygmenų kraštovaizdžio objektų kūrimo darbuose (Jakovlevas-Mateckis 2008). Pirmajame lygmenyje rengia miesto ar miestelio kraštovaizdžio architektūros objektų - želdynų (ivvairios paskirties parkų bei sodų, skverų, kapinių, paplūdimių, rekreacinių miesto miškų ir pan.), pastatų ar jų kompleksų aplinkumos koncepcijas, detalius planus, techninius projektus ir pan. Antrajame lygmenyje kartu su architektais kuria lokalias miesto ar miestelio kraštovaizdžio architektūros dalis: gyvenamają, pramonès, komercinę, visuomeninę, rekreacinę ir kt. Trečiajame lygmenyje kartu su miesto planuotojais rengia bendruosius ir specialiuosius planus, spręsdami juose kraštovaizdžio tvarkymo ir formavimo, 
gamtinio karkaso, želdynų sistemų klausimus, kurie apima kraštovaizdžio išsaugojimo, tobulinimo, atkūrimo ir kūrimo veiksmus, rengia saugomų teritorijų specialiuosius planus. Ketvitajame lygmenyje kartu su teritorijų planuotojais rengia šalies, regiono ir savivaldybès teritorijų planavimo dokumentus, spręsdami juose kraštovaizdžio planavimo klausimus.

Tarptautinès kraštovaizdžio architektūros federacijos (angl. International Federation of Landscape Architecture - IFLA) ir Vokietijos kraštovaizdžio architektu asociacijos (vok. Bund Deutscher Landschaftsarchitekten - BDLA) pateikiamoje medžiagoje išsamiai apibūdinama kraštovaizdžio architekto veikla, atskleidžiamos dabartiniu metu šiai profesijai priskiriamos darbų apimtys. Pasak BDLA, kraštovaizdžio architektai kuria atviras erdves judejjimui, sustojimui ir minčiai. Jie sujungia ekologinị sąmoningumą, planavimo ir projektavimo kompetenciją bei kūrybiškumą, kuriant funkcines ir estetiškai patrauklias atviras erdves, tuo pat metu apsaugant gamtos išteklius. Pagrindinè kraštovaizdžio architektų užduotis - atvirų erdvių ir projektų planavimas ịvairiose aplinkose. Jie planuoja visų tipų žaliąsias ir išorines erdves, prižiūri projektų kūrimą ir ịgyvendinimą bei užtikrina jų ilgalaikę priežiūrą. Kraštovaizdžio architektai apibrěžia kraštovaizdžio struktūrą ir panaudojimą bei jo paviršių konfigūraciją. Jie parenka tinkamus augalus ir nustato sodinimo planą. Jie priima sprendimus dèl grindinių ir aptvérimo, taip pat lauko baldų ir meno kūrinių naudojimo (BDLA 2018). Kraštovaizdžio architektai taip pat aktyviai veikia ir kitose srityse, susijusiose su atviromis erdvėmis ir kraštovaizdžiais, pavyzdžiui, kaimo rekonstrukcijos, miestų planavimo ir regeneravimo projektų srityse. Čia kraštovaizdžio architektai turi bendradarbiauti su architektais, miestų planuotojais, statybos inžinieriais, biologais, sociologais ir kitais specialistais (BDLA 2018). Kraštovaizdžio architektai planavimo ir projektavimo klausimais konsultuoja apželdinimo ir aplinkos tvarkymo įmones, vyriausybines agentūras ir savivaldybių viešujų erdvių ir parkų skyrius, vandens valdymo institucijas ar gamtos apsaugos istaigas (BDLA, IFLA Europe 2018).

BDLA ir IFLA Europe duomenimis kraštovaizdžio architektūros veikla apima strategini, planavimo ir projektavimo bei administravimo ir vadybos lygmenis. Pirmajị, strateginị lygmeni sudaro dvi kraštvaizdžio architektams priskiriamos darbų grupès. Pirmos grupès darbai apima atsargumo priemones aplinkos atžvilgiu bei jos apsaugą vietovès ir regioniniame planavime: regioninès kraštovaizdžio programos ir kraštotvarkos planai; regioninès plètros koncepcijos, bendruomeninès ir tarpkultūrinès infrastruktūros studijos; aplinkos planavimas; pramogų parkų planavimas ir programos bei plataus masto kraštovaizdžio atkūrimas; koncepcijos kraštovaizdžio konversijai ir taršos išvalymui; apleistų pramoninių teritorijų ir gyvenviečių atkūrimo tyrimai; bendrosios upių, upelių ir ežeru atgaivinimo koncepcijos; mokslinių tyrimų projektai, susiję su aplinkos apsauga ir išsaugojimu; gamtos apsaugos valdymas. Strateginio lygmens antros 
grupès darbai apima kraštovaizdžio užduotis miestų žemės naudojimo srityje bei bendraji ir sektorinị planavimą: želdynų ir atvirų erdvių planavimas kaip miesto žemès naudojimo planavimo dalis; kraštovaizdžio vystymo planai; poveikio aplinkai vertinimas atsižvelgiant i vietą ir tinkamumą; planavimo ir plètros programų poveikio aplinkai tyrimai; kraštovaizdžių ir gamtinių teritorijų planavimas ir pavaizdavimas žemėlapiuose; buveinių planavimas ir plètra; nacionalinių parkų, biosferos ir gamtos rezervatų bei kraštovaizdžio apsaugos teritorijų planavimas; paslaugos, susijusios su teritorijų apsaugos teisinėmis ir administracinèmis procedūromis; kraštovaizdžio priežiūros planai infrastruktūros vystymui ir projektų planavimui; poveikio aplinkai vertinimas pagal poveikio mažinimo taisykles; mineralu gavybos ir regeneravimo planavimas; detalios poveikio mažinimo priemonių dokumentacijos parengimas ir tvarkymas; techninès priežiūros ir plètros planai; tęstinių darbų planavimas; stebejjimas. Antraji lygmeni sudaro dvejopo pobūdžio planavimo darbai. Viena šių grupių apima infrastruktūros studijas, plètros planavimą ir kraštovaizdžio programas: gamtinio potencialo išsaugojimo koncepcijos ir lietaus vandens valdymas; žemès ūkio planavimas ir ekspertų išvados dèl žemès konsolidacijos; miškų planavimas; žemès ūkio ir miškininkystės ekstensifikacijos koncepcijos; žemès naudojimo planavimas; žaliujų intarpų koridorių bei kertinių žaliojo tinklo vietų koncepcijos; sporto ir poilsio zonų plètros planai; horizontalus ir vertikalus dviračių, pėsčiujų takų ir gamtos koridorių suderinimas; maršrutų, kilpinių takų, slidinėjimo trasų, sporto kompleksų ir arenų, žiemos sporto, motorinio sporto, vandens sporto, jodinèjimo, dviračių ir bejgimo takų planavimas. Antrają grupę sudaro miesto ir kaimo pertvarkymo planavimo darai: miesto plètros ir regeneravimo planavimo schemos ir projektai, žemės naudojimo ir struktūros planai; gyvenamujjų, komercinių ir pramoninių zonų želdynų koncepcijos; sklypų ir želdynų planavimas; konceptualus indèlis i miestų plètros ir infrastruktūros planavimo projektus; miesto ir kaimo struktūrų atgaivinimo bei atnaujinimo planai; ekologinis būsto ir gyvenviečių planavimas; ekspertinè nuomonè dèl tvaraus planavimo. Trečiajji lygmeni sudaro projektavimo darbai, kuriuos galima suskirstyti ic dvi temines grupes. Pirmają projektavimo darbų grupę apima visų lygių ir etapų projektai: viešieji ir privatūs parkai ir žaliosios erdvès; skverai ir aikštès, viešosios vietos ir miesto paminklai; pesčiujų zonos ir ribojamos eismo zonos, promenados; sporto kompleksai (stadionai, arenos, aikštės ir aikštelès); vaikų, jaunimo ir suaugusiujų žaidimų aikštelès ir poilsio erdvès; specialūs ịrenginiai: laipiojimo sienos, dviračių, slidžių trasos, golfo aikštynai, lauko baseinai, maudymosi zonos ir paplūdimiai; kempingai ir nameliai; SPA parkai ir poilsio erdvés; sodininkystès parodos ir koncepcijos kitoms lauko mugems; botanikos ir zoologijos sodai; kapinès ir memorialai; atviros erdvès aplink viešuosius ir privačius pastatus; automobilių aikštelès; pramoninių ir komercinių teritorijų apželdinimas; kelių ir greitkelių aptarnavimo zonų ir poilsio zonų projektavimas ir integravimas; privatūs sodai ir 
kiemai; stogo sodai ir terasos; žiemos sodų ir patalpų apželdinimas. Antrają projektavimo darbų grupę sudaro istoriniai parkų ir sodų tvarkybos uždaviniai: istorinių parkų ir sodų dokumentacijos analizé, pildymas ir rengimas; istorinių parkų ir sodų inventorizavimas bei vertybių nustatymas; istorinių parkų, sodų ir kitų žaliujjų erdvių atkūrimo koncepcijos; augalų išdèstymas pagal istorinius modelius ir atkūrimas pagal istorinius apželdinimo projektus; pasiūlymai dèl istorinių vandens funkcijų - fontanų, kaskadų ir tvenkinių atkūrimo; istorinių parkų ir sodų architektūrinių elementų, statulų, skulptūrų ar kitokių paminklų atkūrimo projektai.

Ketvirtasis kraštovaizdžio architektui priskiriamų darbų lygmuo apima administravimo ir vadybos klausimus, kurie skirstomi ị projektų kontrolès, stebėsenos, iggyvendinimo uždavinius bei ekspertų konsultacinès paslaugas, idèjų pristatymo, tarpininkavimo veiksmus. Pirmos grupès administravimo lygmenyje darbus sudaro: projektų valdymas ir kontrolè; parbo planavimo procedūros, statybos aikštelių logistika, medžiagų pirkimas; statybos standartų ir medžiagų specifikacija; koncepcijos, kaip sumažinti statybos poveikị aplinkai; siūlymai poveikio aplinkai mažinimo reguliavimui naudojant ekologiškas technologijas; projektų priežiūra, atliktų darbų apskaita ir ịgyvendinimo kontrolé; želdynų valdymas - kūrimo ir priežiūros planavimas ir organizavimas; konfliktų valdymas (bendrų problemų ir nemokumo atveju). Antrają grupę sudaro šie kraštovaizdžio architektų darbai: projektavimo ir architektūros konkursų organizavimas ir vertinimas; viešojo planavimo procedūrų priežiūra ir vykdymas; ekspertų nuomonių rengimas; konfliktu valdymas ir tarpininkavimas; visuomenès dalyvavimo ir apklausų organizavimas, projekto pristatymas; vizualizacijos, filmų ir fotografijų dokumentai; parodų ir pristatymų organizavimas; ryšiai su visuomene.

Kaip teigia J. Corner (2010), dabar architektūros mokyklos ieško ịkvėpimo ir atsinaujinimo kraštovaizdžio planavime ir projektavime, nors prieš keletą metų buvo neịsivaizduotina domėtis medžiu ar kraštovaizdžiu. Šiandien pastebimas ne tik susidomejjimas augalija, žemès darbais ir teritoriju planavimu, bet ir gilus susirūpinimas dèl kraštovaizdžio koncepcijų; gebejimas teoriškai ištirti vietas, teritorijas, ekosistemas, tinklines sistemas ir infrastruktūras bei organizuoti didelius miestų plotus. Pagrindinès temos - dinaminè sąveika, ekologija ir technika rodo besiformuojančią laisvesnę urbanistiką, labiau orientuotą i realų miestų sudètingumą ir siūlančią alternatyvą griežtiems centralizuoto planavimo mechanizmams. J. Corner (2010) pažymi, kad kraštovaizdžio architektūros mokyklos suvokia, kad jų profesijos sritys išaugo ir persipina su architektūra ir urbanistiniu projektavimu, ir mato kraštovaizdžio architektūrą kaip lyderiaujantị metodą urbanistikoje. Pastaruoju metu kraštovaizdžio architektūros studijų programose išeinama iš profesionaliai apibrež̌tų ribų, kad būtų galima išplèsti savo ịgūdžius sudètingose urbanistinèse ir infrastruktūros srityse. Panašu, kad tam tikri elementai kiekvienoje iš projektavimo profesijų - architektūros, kraštovaizdžio ar- 
chitektūros, urbanistinio projektavimo ir planavimo, pereina ị bendrą praktiką, kuriai terminas „kraštovaizdis“ turi svarbiausią ir sujungiančią reikšmę (Corner 2010). 1989 m. Europos bendrijos (dabar ES) šalių kraštovaizdžio architektus vienijančios nacionalinès organizacijos pasirašè deklaraciją dèl Europos kraštovaizdžio architektūros fondo (EFLA), vèliau (2012) pavadinto Europos kraštovaizdžio architektūros federacija (angl. European Federation for Landscape Architecture, EFLA), steigimo, savitarpio akademinès kvalifikacijos pripažinimo ir minimalaus išsilavinimo reikalavimų taikymo kraštovaizdžio architektūros srityje. Europos šalių kraštovaizdžio architektūros studijoms, norint gauti profesionalu pripažinimą, keliami reikalavimai išdèstyti $2011 \mathrm{~m}$. bendrame IFLA Europe ir ECLAS (angl. European Council of Landscape Architecture Schools) dokumente ir patvirtinti $2011 \mathrm{~m}$. IFLA Europe Generalinėje Asamblëjoje. Šio dokumento teiginiai iliustruoja, kokių kompetencijų reikia turèti dirbant kraštovaizdžio architektūros srityje. Žinių, supratimo ir gebejjimų reikalavimai kraštovaizdžio architektams skirstomi i praktinę, teorijos ir precedento, technologijų ir tvarumo, fizinių, ekologinių, socialinių ir kultūrinių procesų bei profesinès vertybès bei etikos sritis. Šiame dokumente kraštovaizdžio architektų profesija apibrèžiama taip: kraštovaizdžio architektai tiria, analizuoja ir realizuoja kraštovaizdžio potencialą visuose pletros proceso etapuose, masteliuose ir kontekstuose, ịskaitant: kraštovaizdžio planavimo ir plètros politiką; galimybių studijas; strategines vizijas, planus ir apžvalgas; bendraji planavimą ir erdvinị projektavimą; konkrečių objektų projektavimą; projektų igyvendinimą; ilgalaikę priežiūrą ir valdymą (Minimum...2011).

Pagal Lietuvos profesijų klasifikatorių LPK 2012 (atitinka Tarptautini standartini profesijų klasifikatorių ISCO-08), kraštovaizdžio architektai projektuoja ir planuoja kraštovaizdi bei atviras erdves tokių objektų, kaip parkai, mokyklos, valstybinès įstaigos, keliai, prekybos, pramonès ir gyvenamujų rajonų išorinès teritorijos, planuoja ir kontroliuoja jų statybą, priežiūrą ir remontą (LPK 2012). Daugelis šių užduočių apima bendro pobūdžio kompetencijas, bet atskleidžia išties plačias atsakomybès ribas, kuriant ir igyvendinant kraštovaizdžio architektūros projektus.

\subsection{Kraštovaizdžio architektūros raiška XIX-XX amžių urbanistiniuose procesuose}

Garsus kraštovaizdžio architektas, miestų planuotojas ir teoretikas Geoffrey Jellicoe (1900-1996) teigia, kad ,atnešti“ gamtą ị miestų centrą ir ją pritaikyti, buvo kiekvienos pažangios civilizacijos tikslas. Kraštovaizdžio projektavime pirmoji individualios asmenybės išraiška buvo namo, sodo ir miško kompleksas, tas nepajudinamas pagrindas, nuo kurio prasideda amžinai besikeičianti, taip 
žmogui būdinga santykinès distancijos idèja arba ryšys tarp mažo-didelio ir laikino-amžino (Jellicoe 1975).

\subsubsection{Miesto ir jo želdynų raida $\mathrm{XIX-XX}$ amžių sandūroje}

Moderniojo miesto gimimą lèmė industrinè revoliucija, pramoninès gamybos plètra. Greitai buvo suvoktas miesto ,žaliųju plaučių“ ir estetinio prado sinergijos poreikis. Miesto želdynai, viešasis parkas tapo neatskiriama moderniojo miesto sanklodos dalis. Želdynų svarbą suvokè Niujorko Centrinio parko (Central Park) kūrèjai, Paryžiaus miesto reformatoriai baronas Georges-Eugène Haussmannas (1809-1891), inžinierius Jean-Charles Adolphe Alphand (18171831), Eugène Belgrand (1810-1878), su jais dirbę kraštovaizdžio architektai Jean-Pierre Barillet-Deschamps (1824-1873), Edouard André (1840-1911). Urbanizacijos ir pramonès proveržis pasaulio didmiesčius XIX a. viduryje paskatino ieškoti miestų gražinimo ir gyvenimo kokybès gerinimo (dabar sakytume miestų humanizavimo) sprendinių. Miesto želdynų - viešojo parko, apželdintų aikščių, skverų, alèjų ir bulvaru - idèja užgimè, augo ir buvo realizuojama su didžiuliais užmojais ir didele atida daugelyje didmiesčių, pramonès centrų ir šalių sostinių tiek Senojo, tiek Naujojo pasaulio žemynuose.

Sodai, parkai, skverai per visą urbanizacijos laikotarpi išliko ir lieka pagrindiniu miesto aplinkos kompozicijos ir funkcijos elementų deriniu, be kurio šiuolaikinis miestas negalètų pasiekti urbanistinès darnos. Atvirkščiai, miesto parkas jau nuo XIX a. vidurio buvo pagrindinis miestų kvartalo vertingumo didinimo katalizatorius. XIX a. pabaigoje viešasis miesto parkas buvo miesto planavimo ir nekilnojamojo turto plètros veiksnys (Deveikis, Deveikienè 2009), rinkodaros priemonè, miesto prestižo ženklas. Šiuo požiūriu labai ịdomūs urbanistinio sprendimo pavyzdžiai yra prancūziškosios tradicijos (E. André mokyklos) kraštovaizdžio specialistų parengti ir įvykdyti parkų projektai Liverpulyje (Seftono parkas, aut. E. André), Liuksemburgo mieste pertvarkant tvirtovę (aut. E. André ir R. André), Kordobos mieste Argentinoje (Sarmiento parkas, aut. C. Thays) ir kt. Visuose objektuose matome aiškiai išreikštą privačios ir viešosios erdvès verčių sinerginị ryšị.

Kraštovaizdžio architektūros ir urbanistikos srities veiklų sąveikos tyrime svarbi aplinkybė yra ta, kad prancūziškas žodis ,urbanisme“ Prancūzijoje pirmąkart pavartotas $1909 \mathrm{~m}$. Liono aukštosios komercijos mokyklos profesoriaus Pierre Clerget studijoje L'Urbanisme. Etude historique, géographique et économique (liet. „Urbanizmas. Istorijos, geografijos ir ekonomikos studija“). Pirmieji Prancūzijos urbanistai atèjo iš miesto „pagražinimo ir sveikatinimo“ specialistų būrio - kraštovaizdžio architektų, miesto planuotojų, miestų viešujjų parkų kūrèjų. $1911 \mathrm{~m}$. ịsteigtos Prancūzijos architektų urbanistų bendrijos (pranc. Société française des architectes urbanistes), $1914 \mathrm{~m}$. užregistruotos kaip SFU, Société française des urbanistes, steigèjai buvo ne tik architektai 
Eugène Hénard (1849-1923), Jacques Marcel Auburtin (1872-1926), Alfred Hubert Donat Agache (1875-1959), Henri Prost (1874-1959), bet ir kraštovaizdžio architektai Jean Claude Nicolas Forestier (1861-1930), Edouard Redont (1862-1942), René André (1867-1942). Anglijoje 1909 m. Stanley Adshead (1868-1946) ịkūrè pirmają pasaulyje miestų planavimo katedrą Liverpulio universitete, o Raymond Unwin (1863-1940) išleido knygą Town Planning in Practice, kurioje aptarè miestų-sodų idèjos realizavimą.

Miesto želdynų reikšmę aptare ir pristatė prancūziškosios parkų kūrimo tradicijos atstovas Charles (Carlos) Thays (1849-1934), teikdamas $1891 \mathrm{~m}$. konkurso medžiagą Buenos Airių miesto tarybai (chuntai) Želdynų (tuomet vadintos Promenadų) direkcijos vadovo postui užimti: „Žmogui, ypač dirbančiam, reikia prasiblaškyti, o ar gali būti kas nors sveikiau, didingiau, tikriau, nei tai, kad žmogus moka vertinti, stebèti medžius, nuostabias gèles, mėgautis tuo? Dvasia tuo metu ilsisi, bent trumpam pasimiršta nuoskaudos, o grožis ir tyrumas iškart paveikia širdị. Žmogus vèl tiki savo darbu, savo šeima, skatinamas palankesnių tikslų, nei tie, kuriuos turejo nesimėgaudamas tokiomis kontempliacinėmis akimirkomis“. Aišku, jis priminė „miesto plaučius“, želdynų teikiamas oro drègmès, cheminès taršos, saulès šviesos, oro temperatūros reguliavimo funkcijas (Deveikis et al. 2014).

Permąstyti kai kurias modernejjančio miesto ir želdynų vietos jame doktrinas dar 1889 m. kvietė austrų architektas Camillo Sitte (1843-1903). Jis siūlè nerikiuoti medžių prie gatvių, teikdamas, kad medžiai atliktų sanitarinę funkciją, nedera jų sodinti gatvėse, bet reikia juos perkelti ị didesnių pastatų kvartalų vidų. C. Sitte klaida laikè sprendimus paversti parkus ir kitus želdynų plotus atviromis erdvėmis, jis teige, kad kadaise ịrengiant želdynus mieste buvo elgiamasi priešingai. Anot jo, modernusis viešasis parkas ar sodas, atviras vejjui ir orui, yra padengtas gatvès dulkių, išskyrus tuos atvejus, kai nuo to ji apsaugo jo milžiniškas dydis (Samalavičius 2013; Sitte 1889[1918]). Želdinius C. Sitte interpretavo kaip labai svarbius architektūros harmonizavimo elementus, todèl jam rūpejo, kad medžių išdèstymas urbanistiniuose ansambliuose neužgožtų architektūrinių statinių grožio.

Šiuolaikinio miestų planavimo pradininku laikomas škotų biologas, sociologas, geografas ir filantropas Patrick Geddes (1854-1932), eksperimentavęs Edinburge ir miesto analizès bei planavimo ịžvalgas aprašęs $1915 \mathrm{~m}$. leidinyje Cities in Evoliution. Jo miesto planavimo principai buvo pagrịsti ekologija, kuri buvo suprantama kaip civilizuoto gyvenimo menas ir mokslas (Jellicoe 1975). Neatmetama, kad jo idejos turëjo įtakos miesto sodo ir kitų urbanistikos teorijų bei praktikų kūrejjams.

XIX-XX a. sandūroje racionalios miestų organizacijos klausimus gvildeno ne tik miestų administracijos valdininkai, miestų klausimu tuo metu aktyviai domejjosi plačioji visuomenè. Ją vedè du pagrindiniai siekiai. Pirmasis - sudaryti 
žmonėms sveikas gyvenimo sąlygas, antrasis - sukurti žmogišką visuomenę. Gyventojų sveikatai, manyta, didelę reikšmę turi sveika aplinka, o ją lemia želdiniai (Staniūnas 2012). Ebenezer Howard (1850-1928) pasiūlyto miesto-sodo idejos, išsakytos jo leidinyje Garden Cities of Tomorrow (1898), lèmè miestu sodų judèjimo atsiradimą, o šis judèjimas lèmé daugeli priemiesčių modelių. Miesto-sodo idejja pasklido po Europą ir Šiaurès Ameriką ir iš esmès tebèra praktiškai taikoma ir interpretuojama. E. Howard miesto-sodo erdvinès struktūros pasiūlymai, sandaros principai yra nekart aptarti (Samalavičius 2013). Šimtametes, bet vis dar gyvas miesto-sodo idejas yra aptarusi Dalia Bardauskiené. Pasak jos, Jungtinès Karalystès pažangi urbanistinès plètros modeliavimo patirtis yra daugiausia siejama su E. Howardo miesto-sodo koncepcija (Bardauskiené 2013). E. Howard iš esmès sukuria alternatyvios visuomenès modeli, grịstą bendradarbiavimu: žmonès patys sprendžia dèl savo pačių statybinès, ekonominės ir socialinès aplinkos. Daugeliu atvejų E. Howardo koncepcija yra ekologiška ir turi svarios įtakos dabartinio ekologinio miesto idejoms (Frey 1999). Praktiškai miesto-sodo idèja buvo igyvendinta netoli Londono XX a. pradžioje kitam britu urbanistui Raymond Unwin (1863-1940) su Richard Barry Parker (1867-1947) suprojektavus miestus-sodus Lečvorte (Letchwort Garden City, 1904), Hampstedo priemiestyje (Hampstead Garden Suburb, 1906) ir kt. Tokius projektus rengè ir tęsè ir kiti architektai. 1909 m JAV kraštovaizdžio architektas Frederick Law Olmsted Jr. (1870-1957) ir architektas Grosvenor Atterbury (1869-1956) sukūrè Forest Hills Gardens gyvenvietę prie Niujorko. 1920 m. buvo suprojektuotas ir igyvendintas Velvino miesto-sodo (Welwyn Garden City) projektas Jungtinejje Karalystejje. Prancūzų urbanistas Jacques Marcel Auburtin tarp kitų projektu parengè ir miesto-sodo prie Reimso projektą (Cité-Jardin du Chemin Vert Reims, 1919-1924). Ši koncepcija pasirodè labai patraukli ir sektina. Būta ịvairių bandymų ir projektų sekinių, interpretacijų ịvairiose Europos ir Šiaurès Amerikos šalyse.

Žaliojo tinklo (želdynų sistemos) idèja, struktūrizuojanti miestų plètrą, turi kraštovaizdines ištakas, prasidedančias nuo XIX a. Ši idejja atitinka socialinị dvigubos vizijos - higienos ir estetikos - projektą. JAV kraštovaizdžio architektas Frederick Law Olmsted (1822-1903) XIX a. antroje pusejje išvystė parkų ir jungčiu sistemą (angl. parkways) - plačias, medžiais apsodintas promenadas judejjimui mieste. Tai buvo daroma siekiant užtikrinti patogų miesto parkų lankymą ir sukurti sisteminius ryšius tarp įvairių miesto želdynų (Toublanc 2012).

F. L. Olmsted iki šiol daugelio laikomas šiuolaikinès kraštovaizdžio architektūros pradininku. Jo kartu su anglų architektu Calvert Vaux kūrybą žymi penki ryškūs etapai: Centrinis parkas (angl. Central Park) Niujorke (1857); Vaizdingasis parkas (angl. Prospect park) Brukline (1866); Pakrantès gyvenvietè (angl. Riverside Estate), Čikagoje (1869); Linijinis parkas (angl. The Parkway) Bostone (1880) ir Pasauline Kolumbo paroda (angl. World's Columbian 
Exposition) Čikagoje (1893). Neabejotinai jo darbai darè didelę įtaką visame pasaulyje. Niujorko Centrinis parkas sukūrè naujos miesto kraštovaizdžio erdvės koncepciją, kuri pasižymèjo vidine kompozicija, užimančia didelę teritoriją, bet turinčia savyje daug mažų, turtingų ir ịvairių elementų. Nauji planavimo metodai apėmė pėsčiujų takus ir svarbiausias kryžkeles. Riverside Estate praplečia ir papildo parkų projektavimo teoriją, ijungiant buitinio gyvenimo elementus. Be to, tai vienas pirmujų bandymų griauti griežtą gardelinị Amerikos miestų planavimą (Jellicoe 1975).

Amerikiečių miestų planuotojas, sociologas ir švietējas Clarence Arthur Perry (1872-1944), dirbęs Niujorko miesto planavimo departamente, buvo didysis kaimyniškų bendruomenių ir rekreacinių centrų apologetas. Jis pirmasis aiškiai suformulavo ir paskelbè „kaimynystès vieneto“ sampratą. Jo pagrindinè idèja teigia, kad kaimynystès vieneto ašis yra 1000-1500 mokinių pradiné mokykla, o pagal tai skaičiuojami kiti parametrai. Be kitų rekomendacijų apibrèžtai kaimynystės teritorijai, C. A. Perry siūlè, kad ne mažiau kaip $10 \%$ kaimynystès vieneto teritorijos turi būti skirta želdynams ir rekreacijai juose. Tai buvo savotiška dabartinio želdynų kiekių normavimo užuomazga. Tuo pat metu JAV urbanistas Clarence Samuel Stein (1882-1975) sukūrẻ Niujorko palydovo tipo 25 tūkst. gyventojų Redberno (Radburn) miestelį. Jam būdingi didesni kvartalai, vadinami superkvartalais (superblocks), diferencijuotas gatvių tinklas, pėsčiujų ir transporto eismas izoliuoti, namų gyvenamosios patalpos atgręžtos į želdynų ir pésčiujų takų pusę. I šiuos superkvartalus buvo įterpti platūs žalieji kyliai, pamažu susiliejantys i vientisą komplekso želdinių sistemą. Vèliau šie principai bus labai mėgstami gyvenamųų kompleksų autorių, ypač Europoje. C. S. Stein sukūrè precedentą - kvartalų struktūrą, talpinančią ir intymią individualią erdvę su nedideliais kiemais, ir erdvius želdynų plotus bendrai rekreacijai bei sportui. Naujove laikytinos jo sukurto komplekso namu ,kekès“, ,klasteriai“ (angl. clusters), apaugantys neilgus akligatvius. Šitoks gyvenamosios teritorijos planavimo būdas suaktyvina gyventojų kaimynystès ryšius, sukuriama rami, kamerinè atmosfera, galimybė sujungti vidaus (interjero) ir kiemo gyvenamąsias erdves. Kaip siekė Redberno autoriai, gyventojai gali tiesiogiai jausti gamtą - dirvą, augalus, vandeni, medžius, uolas, netgi samanas ir kerpes (Vanagas 2003).

C. S. Stein dirbo kartu su bendraminčiu architektu ir kraštovaizdžio architektu Henry Wright (1878-1936), kuris taip pat yra žinomas kaip miesto žaliųjų juostų (angl. green belts) populiarintojas. C. S. Stein komandoje dirbo žinomas amerikiečių kraštovaizdžio architektas Marjorie Sewell Cautley (1891-1954), kuris laikomas ịtakingu XX amžiaus miesto vystymo koncepcijų, susijusių su Amerikos bendruomenių kūrimusi. Ta pati komanda parengè ir gerai žinomą, kaimynijos (angl. neighborhood) principu sukurtą Sunnyside of Queens kvartalą Niujorke. Be kita ko, C. S. Stein buvo ir vienas iš Amerikos regioninio planavimo asociacijos (angl. The Regional Planning Association of America, RPAA) 
įkūrejų. Ši asociacija buvo ịkurta $1923 \mathrm{~m}$. ir jungė talentingus urbanistinių reformų šalininkus, kaip Clarence Stein, Benton MacKaye, Lewis Mumford, Alexander Bing, Henry Wright ir kt.

Tradiciniai miestų planavimo ir funkcinio zonavimo postulatai, teorinè ir praktinè veikla nuo XIX a. nuolat buvo susijusi ir su želdynų sistemomis. Čia verta prisiminti ne tik „miesto žaliụjų plaučių“ ar estetinę funkciją, miesto-sodo koncepcijos sklaidą, bet ir rimtus teorinius veikalus, ilgam suformavusius urbanistikos mokslo ir praktikos sprendinius. Pirmiausia tai T. Garnier dar $1904 \mathrm{~m}$. parengtas, o 1918 m. publikuotas veikalas Une Cité industrielle. Etude pour la construction des villes (liet. „Industrinis miestas. Miestu statybos studija“), 1908 m. išleista J. C. N. Forestier knyga Grandes villes et systèmes de parcs (liet. „Dideli miestai ir parkų sistemos“), T. Mawsono chrestomatinis veikalas Civic Art (liet. „Miestu statybos menas“, 1911) ir kiti leidiniai (Mawson 1915, 1927). Miestų planuotojai J. Stübben ir J. C. N. Forestier buvo bene pirmieji įdiegę želdynų normas ir kalbėję apie jų hierarchiją bei daugiafunkcę reikšmę (Stübben 1907; Forestier 1908 [1997]). Pirmoji urbanistikos knyga Prancūzijoje išleista pirmojo pasaulinio karo metais, $1915 \mathrm{~m}$. Tai trijų autorių, SFU narių A. D. Agache, M. Auburtin ir E. Redont, 257 puslapiu veikalas Comment reconstruire nos cités détruites? Notions d'urbanisme appliquées aux villes, bourges et villages (liet. „Kaip atstatyti sugriautus mūsų miestus? Taikomoji urbanistikos samprata ir idejos miestams ir miesteliams"). Prancūzijos ir Didžiosios Britanijos urbanistai daug dirbo keliaudami po kolonijas ir Naujaji pasauli. A. D. Agache dirbo Rio mieste Brazilijoje, J. C. N. Forestier - Maroke, Ispanijoje, Argentinoje ir Kuboje.

1903 m. išplėstą Paryžiaus želdynų kūrimo programą parengė architektas urbanistas E. Hénard. 1923 m. šią sistemą atnaujino ir išplètė kraštovaizdžio architektas, Paryžiaus želdynų (parkų ir promenadų) direktorius J. C. N. Forestier. Šiu projektų tikslas - kad gyventojams didelis miesto parkas nebūtų toliau kaip $1 \mathrm{~km}$, o mažas želdynas - skveras ar sodas $-500 \mathrm{~m}$ atstumu (Les parcs et jardins 2001). J. C. N. Forestier laiko parką privaloma urbanistinio projekto dalimi. Tai gyvenimo, poilsio, meditacijos vieta. Jis tvirtina, kad miesto planas nebus pakankamas, jeigu jame nebus atvirų erdvių programos ir specialaus plano - parkų sistemos plano (Forestier 1908 [1997]). Prancūzai iš esmès pripažịsta valstybès centralizuotai reguliuojamą miestų planavimą ir miesto struktūros vystymą (Projets urbains en France 2002).

Didelių miestų transformacijos ir industrializacijos akivaizdoje J. C. N. Forestier savo $1908 \mathrm{~m}$. knygoje tvirtina, kad apie miestų plètrą reikia pradèti galvoti nuo ,parkų sistemos, kuri sujungia labai įvairias, skirtingo dydžio ir mastelio erdves, pradedant nuo didelių draustinių ir saugomų teritorijų iki rekreacijai skirtų aikštelių, einant per ,aveniu-promenadas“, priemiesčio parkus, didelius miesto parkus, mažus parkus, kvartalų sodus“ (Le Dantec 1996). Ši klasifikacija api- 
ma ne tik miesto parkus ir sodus jų klasikiniu supratimu, bet taip pat tokias teritorijas kaip miškas, pievos, upès, slèniai, kalvos (uolos), kurios, kaip teigia J. C. N. Forestier, ,ateityje jas panaudojant kaip miesto gamtinius struktūrinius elementus, galètų duoti daug naudos“ (Forestier 1908; Toublanc 2012). J. C. N. Forestier pastebi laisvų (neužstatytų) erdvių ir miesto parkų trūkumą ir priešinasi betvarkei, susijusiai su spekuliacija laisva žeme. Jis remiasi Alphando įdiegta administracine ir technine patirtimi, anglosaksišku amerikiečių parkų sistemos modeliu, tapusiu miesto plètros politika, kai želdynas integruojamas ivairiuose jo lygmenyse kaip erdvinio ir teritorinio įvaldymo priemone (Leclerc 2001). J. C. N. Forestier mintis atitinka didelių miestų aglomeracijų lygmens sistemas: „miesto planas nèra pakankamas, jei jame nèra vieningos programos ir specialaus plano, kuriuose būtų numatytos miesto vidinès ir išorinès laisvos (neužstatytos) erdvès, skirtos dabarties ir ateities parkų sistemai“ (Forestier 1908 in Le Dantec 1996). Ši mintis taip pat savo prasme atitinka socialinị projektą, turintị dvi lygiagrečias vizijas: sveikatinimo - jègų atkūrimas gamtoje, ir estetikos miesto grožio kūrimas industrializacijos akivaizdoje.

XIX-XX a. sandūroje besiformavusiose, o XX a. pirmoje pusèje plačiai taikytose tiek linijinio, tiek taškinio ar branduolinio miesto planavimo teorijose ir praktikoje žalieji plotai užima svarbią, sudètinę urbanistinio audinio funkcinę ir kompozicinę dalį. Pavyzdžiui, linijinio miesto teoretikas ir praktikas Ispanijos inžinierius Arturas Soria y Mata (1844-1920) ịsivaizdavo linijinị miestą būsiant nepaprastai žalią - 4/5 viso miesto plotų turètų sudaryti želdiniai. Gyventojai, ịsikūrę išilgai ašies, turètų du privalumus: viešajị transportą priešais namų duris ir ramią, kaimišką aplinką užnugaryje. Gyvenamosios zonos pakraščiu turejjo driektis gausiai apželdinta parkų juosta, už jos dirbamos žemès laukai. Žaliojoje zonoje patogiais pasiekti tarpais buvo numatytos mokyklų vietos (Vanagas 2003). Rusų urbanisto Nikolajaus Miliutino (1889-1941) linijinio miesto sampratoje atsiranda apsauginių želdinių sąvoka. Pavyzdžiui, tuometinio Stalingrado funkcinių zonų išdèstymo plane didžiuli traktorių gamyklos miestą tarp Volgos ir lygiagrečios geležinkelio linijos zonavo taip: prie geležinkelio linijos šliejosi gamybinè juosta, už jos sanitarinè apsauginé žalioji juosta, už jos - gyvenamoji teritorija, dar toliau - poilsio zona Volgos paupyje (Vanagas 2003). Linijineibranduolinei miesto planavimo koncepcijai lengvai taikomi miesto-sodo principai. Buvusioje SSSR išrutuliotoje kompleksinio pramoninio-gyvenamojo rajono planavimo koncepcijai būdinga tai, kad pramoninis gyvenamasis rajonas turejo būti ne mažesnis kaip 25-35 tūkst. gyventojų, užstatymas sutankintas, daugiaaukštis centre ir nuosekliai žemejjantis ị pakraščius, susiliejančius su supančiais želdynais, su žaliąja rekreacijos zona, su vaikų ir švietimo ịstaigų sklypų salomis (Vanagas 2003). 


\subsubsection{Modernizmo ir postmodernizmo laikotarpiai}

Po Pirmojo pasaulinio karo daugelio Vakarų šalių ekonomikai pasikeitus iš žemès ūkio ị pramoninę, keitèsi miesto augimo tempai ir kiekybiniai rodikliai bei kokybiniai kriterijai. Statyboje vietoj anksčiau naudotų vietinių natūralių medžiagų, pradèta naudoti sintetines ir fabrikines. Kraštovaizdžio planavimas iš aplinkos planavimo virto ūkinio planavimo būtinybe (Jellicoe 1975). $1907 \mathrm{~m}$. Alberto Einšteino reliatyvumo teorija atvėrè naują revoliucinę laiko ir erdvès koncepciją. Mokslas judèjo i prieki paprastam žmogui sunkiai suprantamu greičiu, pateikdamas vis naujus galios šaltinius, galinčius žmogaus rasei suteikti klestėjimą arba būti jos sunaikinimo priežastimi. Grynasis konstruktyvizmas architektūroje vienu metu tapo dominuojančiu Rusijoje, Nyderlanduose, Vokietijoje, Prancūzijoje (Jellicoe 1975).

XX a. urbanistikos radikalioji didaktinè (ir paveikioji, turejjusi įtakos visoje Europoje ir pasaulyje) teorija ir praktika sietina su dviem prancūzu architektais ir urbanistais - Tony Garnier (1869-1848) ir Le Corbusier (tikr. CharlesEdouard Jeanneret-Gris, 1887-1965). Jų projektuose ir darbuose, publikacijose buvo suformuluoti miesto funkcinio zonavimo principai, ilgam ịsirěžę ị urbanistikos mokslo ir praktikos sprendinius. Šiuose projektuose miesto funkcines zonas skiria ir jungia želdynai. Le Corbusier savo jaunystès kelionès ị Artimuosius Rytus metu stebejosi islamo (Rytų) miestų želdinimo tradicijomis. Gal todèl Modernios architektūros tarptautiniam kongresui (CIAM) 1933 m. jis tvirtino, kad „urbanistikos medžiagos yra saulè, erdvè, medžiai, plienas ir armuotas betonas, tokia tvarka ir tokia hierarchija“. $1933 \mathrm{~m}$. Le Corbusier suredaguotoje chartijoje buvo smulkiai aptartos visos keturios, su žmogaus veikla susijusios terpès (gyvenamoji aplinka, darbas, poilsis, susisiekimas) ir jas aptarnaujančių veiksnių sąlygos. Kiekvienoje iš jų žalieji plotai atlieka atitinkamai svarbų vaidmenį. Gyvenamajai aplinkai - namų kvartalams turi būti parinktos pačios geriausios miesto vietos - saulètos, gausiai apželdintos, patogiai pasiekiamos. Darbo aplinkoje želdiniams priskiriama apsauginè funkcija: pramonès sektoriai turi būti atskirti nuo gyvenamųjų namų kompleksų atitinkamo pločio želdinių juostomis. Poilsio veiksnys visų pirma siejamas su žaliujų plotų integracija: ypač didelis dèmesys turi būti skiriamas poilsio įrenginiams prie namų. Kiekvienas gyvenamasis kvartalas turi būti su žaliaisiais plotais, skirtais jaunimo ir suaugusiujų poilsiui. Šias teritorijas turi numatyti vietos žemès naudojimo įstatymai. Užstatyto ir laisvo teritorijos ploto santykis turi būti griežtai reglamentuotas. Pabrěžiama, kad želdiniai - tai ne tik miesto puošmena, jie turi tarnauti naudingiems tikslams. Visa tai turi būti sukuriama nepažeidžiant gamtos, išsaugant esamą kraštovaizdi, jo vertybes (Vanagas 2003).

Prabègus keleriems metams po Antrojo pasaulinio karo, Prancūzija ir kitos Europos šalys skubejjo spręsti sugriautų miestų atstatymo ir tankejjančio apgyvendinimo problemas. Kaip žinome, Le Corbusier ir jo bendraminčiai siūlè 
tiems laikams patrauklias miesto vystymo idejjas, kurios be skrupulų ignoravo praeities urbanistines tradicijas, siūlè be gailesčio atsisakyti problemas sukeliančio istorinio užstatymo. Ši nauja paradigma iš esmès keite požiūrị i susiklosčiusią senųų miestų želdynų (parkų, miesto sodų, skverų) sistemą. Tuomet įsivyravo nauja užstatymo morfologija, kai masyvūs daugiaaukščiai pastatai stiebėsi viršun, ant žemės užimdami tik keturis penktadalius jam skirto sklypo (Blancot 2001). 1957 m. Prancūzijoje išleistoje sodų enciklopedijoje (pranc. Encyclopédie des Jardins) išsakyta mintis, kad „mūsų dienų šiuolaikinis žmogus jaučia vis didesni poreiki atkurti kontaktą su gamta ir jos kuo natūralesnèmis formomis ir spalvomis“ liudija XX a. vidurio urbanistinès visuomenès nuostatas gamtos atžvilgiu (Encyclopédie 1957). Le Corbusier teigè: „naujas laisvo užstatymo ir atvirų apželdintų erdvių principas, nesumažinant tankumo, suteiks paryžiečiams džiaugsmą gyventi tarp medžių ir žalumos“. Modernizmo metras kritikavo senąją Paryžiaus parkų sistemą, sakydamas, kad žmonès turèjo šešias dienas per savaitę laukti, kol turès laisvo laiko ilgais bulvarais, tarsi koridoriais, pasiekti viešus miesto parkus. Jis manè esant daug geriau žalumos plotus kurti čia pat gyvenamuosiuose kvartaluose (Blancot 2001). Tačiau, pasak šiuolaikinių prancūzų architektų, Le Corbusier įsivaizduotos žaliosios erdvès, daugiau paněšèjo ị betono plokščių ekspozicijas, geriausiu atveju „papuoštas“ betoninèmis gèlinèmis. 1978 m. prancūzų miesto kūrẻjai nusprendè grị̌ťi prie tradicinio Paryžiaus urbanistinių erdvių komponavimo, kuris išsaugo susiformavusị gatvių tinklą, turi aiškius sklypus, kiemus, sodus ir miesto parkus (Blancot 2001).

Amerikiečiu istorikas, sociologas, filosofas ir literatūros kritikas Lewis Mumford (1895-1990) yra palikęs darbų, kurie yra aktualūs ir dabar. Miesto viešųų erdvių, kaip gyventojų bendruomenès jungimo vietu poreikio, miesto rekreacinių erdvių akcentavimu L. Mumfordas yra artimas europietiškajai urbanistikos tradicijai. Jis suvokè viešųjų erdvių - aikščių ar parkų - planavimo sąsajas su vyraujančiu miesto gyvenimo būdo modeliu, teigè, kad tik gyvenimo būdo kontekste galima suvokti tikrąsias viešujų erdvių funkcijas. Veikale „Miesto perspektyva“" (angl. Urban Prospect, 1968) jis pabrěžè urbanistinės politikos reikalingumą. Kad miestas išsaugotų istorinị tęstinumą, reikalinga urbanistinè politika, numatanti gyventojų skaičiaus ir tankumo ribojimą, socialinès bei ekonominès veiklos derinimą, vidinị balansą, sąveiką tarp naudingų atvirų ir gyvenamujų erdvių, parkų, sodų ir žaliujų pasivaikščiojimo zonų, kaip integralių urbanistinès aplinkos dalių. Pasak L. Mumfordo, „naujas miesto vaizdinys, kuris atitiks visas jo dimensijas, negali būti paprasčiausiai per vieną naktį atliekamas darbas: jame [mieste] turi likti vietos gamtai, upei, ịlankai, kalnui, miškui, klimatui ir, žinoma, žmonijos istorijai, kultūrai bei sudètingai grupių, organizacijų, institucijų, asmenybių sąveikai“" (Mumford 1968; Samalavičius 2013). Pagreitị igavę ir nuolat vis didesniais mastais ir kiekiais besireprodukuojantys urbanistinès plètros procesai - greitkelių ịsiveržimas ị miestą ir jų skaičiaus didejjimas, 
nuolat augantis priemiesčių skaičius, ilgèjantys susisiekimo tarp gyvenamosios vietos ir darbo atstumai, didejjančios transporto eismo perkrovos ir kita - tokias viešąsias erdves kaip želdynai, sodai ir parkai modernistiniais laikais išstūmè ị miesto socialinio ir kultūrinio gyvenimo paraštes tiek tiesiogine, tiek ir perkeltine prasme (Mumford 1968, Samalavičius 2013).

Kiek kitokią urbanistikos sampratą diegė JAV ir Kanados urbanistė Jane Jacobs (1916-2006). Jos skelbta urbanistikos samprata pirmiausia rèmėsi socialinèmis prezumpcijomis. Miestas, anot jos, negali būti sumeistraujamas profesionalaus architekto ar miesto planuotojo braižybos lentoje ir primetamas visuotinai taikyti. Būtina demokratizuoti planavimo procesą, visuomenè sprendžia, kas tinka ir ko norima, kas svarbu. Jos veikalas „Didžiujų Amerikos miestų mirtis ir gyvenimas" (angl. The Death and Life of Great American Cities, 1961) nagrinèjo sociokultūrini pradą, vèliau autorè èmèsi socioekonominių, miesto ekonomikos klausimu (The Economy of Cities, 1969; Cities and the Wealth of Nations, 1984; The Nature of Economics, 2000). Gatvių socialinio vaidmens refleksijai J. Jacobs skyrè išskirtinị dėmesį. Priešingai nei L. Mumfordas, kuris viešojo miesto gyvenimo funkcijas siejo su parkais, aikštynais ir skverais, J. Jacobs tvirtino, kad geriausiai šias funkcijas atitinka gatvè, nes pats parkų egzistavimas kurioje nors miesto dalyje dar neužtikrina jų vaidmens ir kokybès, nes jie gali būti nesaugūs, nepatrauklūs. Parkai, pasak jos, nèra nei nekilnojamojo turto stabilizatoriai, nei bendruomenès inkarai (Samalavičius 2013). Tai iš esmės kertasi su kitų urbanistų ir miesto vystytojų nuostatomis, kad miesto parkas ar kitoks želdynas yra svarbus nekilnojamojo turto vertès veiksnys ir skatina giliau nagrinèti miesto želdynų ir urbanistinio konteksto kokybinès sąveikos aspektus. Nors, pasak Jellicoe, visą modernizmo periodą dvi jègos - ekologijos ir konstruktyvizmo, buvo opozicijoje, tačiau vienintelis tuo metu bandęs sujungti šias dvi sritis buvo švedų architektas Gunnar Asplund (1885-1940). Jis savo kūryba siekẻ klasicizmo esmę perteikti modernia kalba ir geometrines vertybes harmonizuoti su kraštovaizdžiu. Jo žinomiausi kūriniai yra Stokholme. Tai Miško kapinès (Woodland Cemetery) ir Miesto bibliotekos ir observatorijos sodas. (Jellicoe 1975). Apskritai, Skandinavijos šalys, XIX a. nepatyrusios industrinès revoliucijos išbandymų, pasieke elegantišką sintezę tarp aplinkos ir gyvenimo būdo. Pavyzdžiui, Danijoje dar $1932 \mathrm{~m}$. ekologija buvo ịtraukta ị suaugusiųjų žmonių mokymą. Orhuso universiteto projekto, kurio autoriai buvo architektai K. Fisker, C. F. Moller, P. Steegmann ir kraštovaizdžio architektas C. T. Sørensen (1893-1979) ekologija buvo sudètinè idejjos ir sumanymo dalis. C. T. Sørensen laikomas vienu ižymiausių modernizmo laikotarpio kraštovaizdžio architektų, kurio kūryboje išryškèja modernizmui būdingos griežtos statinio linijos ir grakštaus kraštovaizdžio kontrastas ir sinergija.

XX a. postmodernistinejje kultūroje miesto želdynai - sodai, parkai, skverai - per visą urbanizacijos laikotarpi išliko ir lieka pagrindiniu miesto aplinkos 
kompozicijos ir funkcijos elementų deriniu, be kurio šiuolaikinis miestas negalètų pasiekti urbanistinès darnos. Šią tradiciją prancūzų miesto planuotojai tęsia iki šių dienų. Tokių postmodernistinio laikotarpio kompleksinių urbanistinių sprendimų pavyzdžiai Paryžiuje yra André Citroeno parkas (aut. Gilles Clément su bendraautoriais, 1986-1992), Bercy kvartalo konversija su naujuoju parku (1994-1997, autorių kolektyvas su kraštovaizdžio architektu Philippe Raguin), Maroko Kiemo arba Eolo parkas (2005-2007, aut. Michel Carajoud ir Claire Carajoud).

Kaip pastebi prancūzų mokslininkès Monique Toublanc ir Sophie Bonin, želdynų sistemos idèja XX a. viduryje persikelia ị urbanistikos lauką. Žaliojo tinklo (pranc. trame verte) terminas, ilgai diskutuotas tarpukaryje ir po jo, pagaliau tampa urbanistinio žodyno dalimi. Žaliasis tinklas pirmiausia suprantamas kaip miestų plètotès struktūrinė priemonè, naudojama urbanistinių struktūrų sisteminiam perskyrimui žaliosiomis struktūromis. Žiūrint iš urbanistinių funkcijų taško, žaliasis tinklas tarnauja socialiniams tikslams: suteikia kokybišką kasdieninị kraštovaizdị ir visame mieste tolygiai išdèstytas, gyventojams tarnaujančias gamtines rekreacines erdves (Toublanc; Bonin 2012).

Apie šiuolaikinius prancūzų miesto planavimo bruožus architektè ir urbanistė Ariella Masboungi rašo taip: ,urbanistinis projektas - tai viltinga žinia, kai reikia spręsti miesto problemas, ir politinès valios išraiška, atspindinti laikmečio dinamiką, visuomenès progresą ir lūkesčius" (Masboungi 2002). Anot jos, šiuolaikiniams prancūzų urbanistiniams projektams būdinga konversijos teritorijų gaivinimas, naujų kultūrinių centrų kūrimas, didelis dėmesys šiuolaikinès architektūros raiškai, kraštovaizdžio architektūros sprendinių svarba ir kokybė kiekviename projekte, tarptautinis bendradarbiavimas su geriausiais užsienio projektuotojais (Rem Koolhaas, Manuel de Sola-Morales, Renzo Piano ir kt.), projekto kompleksiškumas - vieningi transporto ir kitos infrastruktūros sprendiniai, bei aukšti žinių ir patirties reikalavimai kuriant, igyvendinant ir valdant projektą.

Parko vaidmeni panašiuose urbanistiniuose projektuose A. Masboungi vertina kaip miesto ar šalies politikos geranoriškumo pasireiškimą ir viešo bei privataus intereso suderinimo ir solidarumo raišką. Parkui ji priskiria ekonominio variklio vaidmenị. Parkas, anot urbanistès, yra stiprus struktūrinis kompozicinis ir funkcinis traukos elementas, kuriame yra svarbi pastatu ir parko architektūros bei funkcijų sąveika. Parkas tarnauja kaip miesto kultūros ir identiteto išraiška, meninės, idejjinès ir filosofinès raiškos, naujausių technologijų ir inovacijų eksponavimo vieta. Tuo pačiu jis yra miesto gyventojų sveikatinimo ir rekreacijos vieta, socialinés aplinkos gerinimo priemonè, saugumo ir užimtumo, naujos urbanistinès kokybės užtikrinimas (Masboungi 2002). Kaip teigia K. JakovlevasMateckis, XX a. bėgyje kraštovaizdžio architektai masiškai projektavo įvairaus tipo miesto parkus (botanikos, zoologijos, memorialinius, pramogu ir kt.), miesto želdynus, saugomas teritorijas, automobilių transporto magistralių želdynus, 
sodus ant stogu ir panašiai. Antrojoje XX a. pusèje jie imasi žmogaus veiklos suniokotų teritorijų rekultivavimo, pramonès ir rekreacinių teritorijų kraštovaizdžio formavimo darbų. Šiuo laikotarpiu ypač populiarūs tampa gyvenamų teritorijų ir net individualių namų, vilų kraštovaizdžio formavimo darbai, taip pat sodų interjere kūrimas (Jakovlevas-Mateckis, 2008).

\subsection{3. Šiuolaikinės kraštovaizdžio architektūros ir urbanistikos sąveikos teorijos ir praktika}

Kraštovaizdžio architektūros ir urbanistikos sąveikos raidai įtakos turèjo ekonominès, politinès, teisinès prielaidos. Spartus ekonomikos augimas ir miestų plètra reikalavo vis intensyvesnio gamtos ištekliu naudojimo ir tai didino aplinkos taršą, kuri septintajame praeito amžiaus dešimtmetyje pasiekè tokị lygị, kad iškilo akivaizdi ekologinès krizès grèsmè. XX a. antrojoje pusèje tapo akivaizdu, kad atėjo laikas iš esmès peržiūrèti visuomenès raidos prioritetus ir apsispręsti dèl tolesnès visuomenès vystymosi krypties. Dar 1972 m. „Romos klubas“ paskelbė ataskaitą „Augimo ribos“, o pagrindinès darniojo vystymosi nuostatos buvo suformuluotos $1987 \mathrm{~m}$. Jungtinių Tautų Aplinkos ir plètros komisijos, kuriai vadovavo tuometinè Norvegijos aplinkos ministrè Gro Harlem Brundtland, ataskaitoje „Mūsų bendra ateitis“. Šioje ataskaitoje buvo pateiktas ir darniojo vystymosi apibrèžimas: „darnus vystymasis - tai toks vystymasis, kuris atitinka dabartinius visuomenès poreikius, nemažindamas ateinančių kartų galimybių tenkinti savus poreikius. Darnaus vystymosi koncepcijos pagrindą sudaro trys lygiaverčiai komponentai - aplinkos apsauga, ekonominè plètra ir socialinis vystymasis“. 1993 m. Europos urbanistikos chartijoje (angl. European Urban Charter), pakeitusioje 1933 m. Atėnų chartiją, pabrèžiamas ir toks siekinys: „Būtinas naujas miesto modelis. Esami modeliai dèl padrikos miestų plètros pasižymi funkcine teritorijų specializacija. Tai XX a. vidurio, moderniojo planavimo padarinys, kuris neturi ateities. Miestai turi kontroliuoti savo augimą. Pagrindinis miestu politikos tikslas - socialinè ir teritorinè sanglauda" (European Urban Charter 1993). Socialinès ir teritorinès raidos plotmeje būtina didesnè miesto planuotojų, urbanistų, architektų, ekonomistų, ekologų, kraštovaizdžio specialistų sanglauda. Urbanistinè doktrina privalo turèti socialinès raidos humaniškajji užtaisą, ji turi būti rengiama, svarstoma ir analizuojama bendrame ekonominès ir socialinès politikos, ekosistemos išteklių naudojimo politikos kontekste.

Kiti priimti dokumentai, kaip $1992 \mathrm{~m}$. Rio de Žaneire pasaulio valstybių viršūnių priimta deklaracija „XXI amžiaus darbotvarké“ (Agenda... 1992), ịtvirtino darnaus miesto idejją pasauliniame kontekste. $1994 \mathrm{~m}$. Aalborgo mieste (Danija) priimta Europos miestų darnaus vystymosi chartija (Charter...1994). 2007 m. Leipcige (Vokietija) priimtoje Leipcigo tvariujų Europos miestų chartijoje teigiama, kad vienas iš gamtinių ir urbanistinių struktūrų sąveikos rezultatų 
turètų būti žalioji infrastruktūra, kaip sėkmingai išbandyta ekologinių, ekonominių ir socialinių problemų sprendimo pasitelkiant gamtoje esančius sprendimus priemonè (Leipcigo... 2007).

Iš tiesų naują požiūrị i urbanistinio planavimo ir projektavimo prioritetus padeda diegti ir Europos komisijos komunikatas (COM(2013) 249), ,Žalioji infrastruktūra. Europos gamtinio kapitalo puoselejjimas", kuriame, be kita ko, yra teigiama, kad gamtos, jos procesų ir daugelio visuomenès naudojamų gamtinių gèrybių apsauga bei stiprinimas turi būti sąmoningai integruojami ị teritorijų planavimą ir plètrą (Europos komisija... 2013). 2016 m. pasirašytas Amsterdamo paktas, kuriuo nustatyta ES miestų darbotvarke ir per JT konferenciją „Habitat III“ priimta Naujoji miestų darbotvarke 2017 m. (angl. New Urban Agenda, 2017) skatina urbanistinius uždavinius spręsti vadovaujantis tvarumo paradigma, o tai reiškia, kad daugelis ateities urbanistinių uždavinių bus tiesiogiai susiję su gamtinių ir kultūrinių išteklių apsauga, bioịvairovès išsaugojimu ir gausinimu, alternatyvia energija, klimato kaitos problemomis, tvaraus vandens ciklo užtikrinimu, visuomenès dalyvavimu, aplinkos kokybès užtikrinimu ir t.t. (New... 2017).

Darnaus vystymosi idejja laikoma viena iš įtakingiausių XX a. pabaigos koncepcijų, turinčių išskirtinị socialinị bei politinị svorị. Jau prieš kelerius metus mokslininkai pastebejjo, kad tokių, faktiškai nuo nulio pradètų iki per porą dešimtmečių visam pasauliui ịtakos turinčių idèjų ir procesų yra nedaug (Staniūnas 2013). Europos šalys i savo teisès aktus perkelia tvaraus vystymosi nuostatas. XXI amžiuje urbanistikos mokslas ieško kelių, kaip integruoti ịvairių mokslo sričių metodus ir išvadas, visų pirma koncentruojantis ị kraštovaizdị ir jo valdymą, kaip alternatyvų būdą ir požiūrị sprendžiant tvaraus miesto klausimus, atsižvelgiant ị kraštovaizdžio teikiamų paslaugų gausą ir integralumą.

Darna arba tvarumas (angl. sustainability) ${ }^{3}$ pastaruoju metu yra viena svarbiausių skètinių, integruojančių ištisą teorinių interpretacijų įvairovę, sąvokų atsinaujinančiame urbanistikos žodyne. Jos koncepcija daro vis labiau pastebimą įtaką ne tik miesto gyventojų mentaliteto kitimui, bet ir profesionalų sąmoningumui, o kartu - planavimo bei projektavimo procesams. Kaip teigia ekonomikos ir ekologijos problemas nagrinejjantis žinomas teologas John B. Cobb (g. 1925), ,planetos dydžio ribotumas reikalauja, kad kurtume žmonių visuomenę, nusibrěžiančią ribas ir kuriančią padorų gyvenimą visiems jų nepažeidžiant. Tokia visuomenè turètų gyventi darniai su kitomis rūšimis ir labiausiai kliautis at-

\footnotetext{
${ }^{3}$ Angliška sąvoka „sustainability“ $i \mathfrak{i}$ lietuvių k. verčiama ir moksliniuose tekstuose vartojama dvejopai - tvarumas ir (arba) darnumas ; iš esmès pirmenybė teiktina sąvokai tvarumas, ji labiau atitinka sąvokos originalą ir vertimus į kitas kalbas, bet urbanistikos moksliniuose tekstuose labiau prigijęs terminas darnumas, darnusis (vystymasis). Šiame darbe abi sąvokos vartojamos kaip sinonimai.
} 
sinaujinančiais planetos ištekliais. Neatsinaujinančius išteklius ji turètų naudoti tik tokiais tempais, kurie priimtini atsižvelgiant $\mathfrak{i}$ technologini progresą, saugiai pakeisdama juos tais, kurių esama daugiau. Aplinkos tarša neturètų viršyti aplinkos galių apsivalyti pačiai“" (Cobb 2007; Samalavičius 2013).

Kaip teigia A. Samalavičius, ,pastaruoju metu urbanistika bei miestų planavimas imami suvokti kaip sudètinga, kompleksiška veikla, kur būtinos ịvairių sričių žinios ir kompetencija, todèl nūdienos urbanistikos samprata apima tokias glaudžiai susijusias ir neretai susipynusias sritis, kaip urbanistinis bei architektūrinis planavimas ir projektavimas, inžinerija, miesto sociologija ir antropologija, geografija, ekonomika, aplinkosauga, architektūros estetika ir kt.“ (Samalavičius 2013). Kūrybingas miestas - tai viena iš tarpdisciplininị bendradarbiavimą skatinančių koncepcijų, kurios autorius yra Charles Landry. Kūrybingo miesto sąvoka nusako, kad čia siekiama ne tiek standartinių sprendimų, kiek naujų požiūrių taikymo pasinaudojant konkrečios vietovès potencialu. Todèl miestas, pageidaujantis atitikti kūrybingo miesto kriterijus, turètų ne tiek sekti griežtomis kitų miestų strategijos gairèmis, kiek adekvačiai ịvertinti savaji kultūrinị savitumą ir ji panaudoti pagal darnios pletros ir ekologijos principus. Pasak Ch. Landry, darni plètra yra svarbiausias šiuolaikinio miesto raidos imperatyvas, tai tarsi prizmé, interpretuojanti pasaulị ir žmogaus veiklą jame (Landry 2005; Samalavičius 2013).

Aptardamas nūdienos miesto plètros problematiką darnos principų kontekste, vienas iškiliausių nūdienos anglų urbanistų ir ekologų Herbert Girardet nurodo, kad „senujjų istorinių miestų „fiziologija“ esmingai skyrèsi nuo moderniujų miestų. Didejjantis žmonių susitelkimas miestuose iš esmès transformuoja ankstesniais amžiais vyravusị urbanistinių ir kaimo vietovių santykị - miestai, užimantys tik $2 \%$ žemès paviršiaus, sunaudoja net $75 \%$ pasaulio išteklių“ (Girardet 1999; Samalavičius 2013). Akivaizdu, kad žmonija anksčiau nesusidūrè su tokiais urbanistinès plètros mastais ir tempais ir pasekmèmis, tai beprecedentinis civilizacijai tekęs iššūkis. H. Girardet pateikia tokị urbanistinès darnos apibrèžimą: „Darnus miestas yra organizuojamas taip, kad visi jo gyventojai galètų patenkinti savo poreikius ir pagerinti buiti, nedarydami žalos gamtiniam pasauliui ir nekeldami pavojaus kitų žmonių gyvenimo sąlygoms - tiek dabartyje, tiek ateityje“ (Girardet 1999; Samalavičius 2013). Pasak H. Girardet, „miestams, kaip ir kitoms organizmų sankaupoms, būdinga metabolizmas - resursų ir produktų tèkmé per urbanistinę sistemą gyventojų labui. Turint galvoje didžiulius urbanizacijos mastus, miestus derètų modeliuoti pagal tai, kaip funkcionuoja natūralios ekosistemos, kaip miškai - tam, kad būtų užtikrintas jų ilgalaikis gyvybingumas. Pačioms gamtos ekosistemoms būdingas iš esmès cirkuliacinis metabolizmas, - kiekviena organizmo pašalinama išeiga tampa įeiga, atnaujinančia ir palaikančia visos gyvenamosios aplinkos, kurios dalis ji yra, tęstinumą" (Girardet 1999; Samalavičius 2013). 
Arizonos (JAV) universiteto profesorè Nan Ellin pasiūlė dar vieną konceptualizuotą bendrają miesto teoriją - integraliają urbanistiką (Ellin 2006). Aptariamoje urbanistès interpretacijoje vengiama tokių urbanistikoje anksčiau naudotų diskursyvių kategorijų, kaip statika, dinamika, plètra, augimas. Vietoje jų pasirinkta kita pamatinè sąvoka - tẻkmè. Integralios urbanistikos samprata jungia tvarkos ir netvarkos elementus, todèl pripažistama urbanistinès tvarkos ir stabilumo stoka, neprognozuojamumas, kartu išvengiant išankstinès tvarkos ir hierarchijos, būdingos urbanistinei utopijai. Vietos, kurioms būdinga tèkmé, išsiskiria šiais penkiais bruožais: hibridiškumu, sujungiamumu, korètumu, autentiškumu ir pažeidžiamumu (Ellin 2006). Ribotas mokslinis pasaulèvaizdis, gamtą traktuojantis kaip valdomą, nuspèjamą ir žmogaus valiai pajungiamą procesą, pastaraisiais dešimtmečiais užleidžia vietą kitokia paradigma grịstam žmogaus ir gamtos pasaulių santykiui. Aplinkosaugos mokslų reikšmės pripažinimas ir akivaizdi globalios ekologinès krizès grèsmè taip pat daro ịtaką keisti įsigalëjusias sampratas, brandinti naują urbanistikos sampratą, kurioje vis mažiau vietos liktų racionalizuotai gamtos ir jos išteklių beatodairiško niokojimo paradigmai, ịsigalejjusiai žmogų èmus vaizduoti esantị už ekosistemos ribų (Samalavičius 2013).

N. Ellin pažymi, kad gamtos, kaip urbanistikos modelio, susigrąžinimas, nuo pat XX a. pradžios igijęs metaforos pavidalą, šiandien yra ne tik metaforiškas. Urbanistės žodžiais, ironiška, kad naujosios technologijos, dabar , irèminančios" šị užbaigtą ratą (arba spiralę), vèl imasi skatinti rinktis gamtoje aptinkamus procesus ir formas. Integralioji urbanistika miestokūrą suvokia kaip nuolatinę ir nesibaigiančią laiko tėkmę, neprieštaraujančią gamtai ir nemetančią jai iššūkio, skirtingai nei tai savo pagrindiniu uždaviniu pavertusi modernybès ideologija (Ellin 2006; Samalavičius 2013).

Urbanistinès estetikos klausimus nagrinejjantis mokslininkas Arnold Berleant pateikia naują įžvalgą: „Urbanistika nebesiremia tokiais gana supaprastintais modeliais, bet pereina ị sudètingesnę stadiją kaip ekosistema. Mechaniškas vienodų, pakeičiamų dalių idealas atmestas, ir siekiama organiškos vizijos. Teigdamas griežtą priešpriešą mechaniškajam, biologinès ekosistemos modelis pripažįsta urbanistikos sritị kaip sudėtingą daugybès skirtingų, tačiau integruotų komponentų vienovę, iš kurių kiekvienas savitikslis, tačiau kartu prisideda ir priklauso nuo konteksto, kuris apima juos visus“ (Berleant 2010; Samalavičius 2013). Miesto humanizavimo moksliniai tyrimai suformavo platformą Naujosios urbanistikos (angl. New urbanism) paradigmai, kuri dar labiau paskatino kraštovaizdžio architektūros poreiki kuriant miesto erdves. Visiškai naują požiūri i kraštovaizdžio architektūros ir urbanistikos sąveiką demonstruoja JAV mokslininkai Ch. Waldheim, M. Mostafavi, J. Corner ir kt. (2006; 2010; 2014) sukūrę 
naują kraštovaizdžio urbanistikos paradigmą. Kraštovaizdžio urbanistika ${ }^{4}$ (angl. Landscape Urbanism) atsirado XX amžiaus paskutiniame dešimtmetyje kaip tradicinio urbanistinio projektavimo kritika, alternatyva naujajai urbanistikai. Tai buvo reakcija ị sparčius miesto pokyčius ir iš esmès horizontalaus pobūdžio šiuolaikinę automobilizmu pagrịstą Šiaurès Amerikos ir Vakarų Europos miestų urbanizaciją. Taip pat buvo reaguota ir i tradicinių urbanistinio projektavimo strategijų nesugebejimą susidoroti su deindustrializacijos sukeltomis aplinkos sąlygomis, padidejusiais ekologiniais reikalavimais ir miesto vystymo procese tebedominuojančia dizaino kultūra (Waldheim 2010).

Kraštovaizdžio urbanistika yra ir ideologija, kuria vadovaujantis miestas gali būti įsivaizduojamas, sumanytas ir suprojektuotas kaip vientisas kraštovaizdis, o tuo pačiu kraštovaizdis suvokiamas ir traktuojamas iš urbanistinių pozicijų. Kraštovaizdžio urbanistikos siūlomi kraštovaizdžio, ekologiniai ir geografiniai modeliai gali būti alternatyvios technikos grumiantis su siaučiančia urbanizacija. Kraštovaizdis daugiau nebegali būti pasyviu vaizdingu pagrindu arba fonu, jis tampa aktualiu varikliu kuriant naujas urbanistinių gyvenviečių formas (Corner 2010). Kraštovaizdžio urbanistika siūlo plačias tarpdisciplininio bendradarbiavimo galimybes ne tik architektūros, planavimo ir inžinerijos, bet ir ekologijos, geografijos, antropologijos, kartografijos, estetikos ir filosofijos srityse. Kraštovaizdžio architekto vaidmuo ir kompetencijos evoliucionuoja iki kraštovaizdžio urbanisto, kuris jau nebèra vien konsultantas, kad pastatų projektus papildytų žaluma, o sprendžia ir vadovauja planuojant ir projektuojant naujas kompleksines urbanistines struktūras ir formas (Corner 2010).

Matymas ir mąstymas per kraštovaizdžio urbanistikos prizmę (angl. Landscape Urbanism Thinking) nèra visiškai naujas dalykas. Kaip teigia Pekino ir Harvardo universitetų kraštovaizdžio architektūros ir urbanistikos profesorius Kongjan $\mathrm{Yu}$, urbanistinio planavimo ir projektavimo istorijoje ir susijusiose srityse galime išskirti penkias tradicijas, gyvuojančias iki šiol. Pirmoji tradicija fengšui ir geomantija (angl. geomancy). Tai ikimokslinis (angl. pre-scientific) kraštovaizdžio urbanistikos modelis, kuriame pirmenybė teikiama natūralioms struktūroms ir procesams (Yu 2010). Analogiškai Lietuvoje šiai tradicijai galètume priskirti pagoniškąsias apsiejjimo su gamta tradicijas, ypač kuriant gyvenvietes ir sakralines vietas. Senosios lietuvių santykio su kraštovaizdžiu tradicijos nagrinejjamos Lietuvių literatūros ir tautosakos instituto mokslininkès dr. Bronès Stundžienès darbuose: straipsniuose „Empatiškoji kultūrinio kraštovaizdžio versija: folklorinis aspektas“ (Stundžienė 2011), „Kraštovaizdžio raišką dainose

\footnotetext{
4 Angliškas terminas Landscape Urbanism kol kas neturi aiškaus lietuviško atitikmens. Galbūt tinkamesnis terminas būtų kraštovaizdine urbanistika arba kraštotvarkine urbanistika, pabrèžiant integralų požiūrị ir veiklos (planavimo ir projektavimo) principus. Paprastumo dèlei disertacijos autorè vartoja sąvokos vertimo formuluotę kraštovaizdžio urbanistika.
} 
apmąstant“ (Stundžienė 2014), publikuotuose mokslo žurnale „Tautosakos darbai“. Senosios fengšui teorijos ir šiuolaikinio miesto planavimas plačiai ir giliai analizuojamos Korejos ir JAV mokslininkų Sun-Kee Hong, In-Ju Song, Jianguo Wu bendrame straipsnyje „Fengšui teorija ir miesto kraštovaizdžio planavimas“. Pasak autorių, fengšui teorija kilusi iš Tolimujų Rytų žmonių sąmoningumo ir požiūrio ị gamtą ir gamtiškus kraštovaizdžius (Tuan 1968; Porker 1974; Needham 1986). Kognityvi ir empirinè fengšui topografijos samprata atrodo labai artima šiuolaikinėms ekologinio kraštovaizdžio vizijoms. Šiuo metu ekologinio tvarumo samprata, atspindinti ekologinès ir žmogaus sistemose gebejjimo prisitaikyti ir keistis kombinaciją (Forman 1989; Zonneveld 1989; Wu ir Loucks 1995; Niemi et al. 1998; Reid et al. 2002) yra suderinama su pagrindiniais fengšui teorijos principais, kurie turi didelę ịtaką Azijos miestų planavimui ir kraštovaizdžio tvarkymui. Fengšui teorija ilgai buvo taikoma Rytų Azijos šalių žemės naudojimo politikoje ir kraštovaizdžio atkūrimo procesuose (Choi 1991; Whang 1991). Iš Kinijos kilusi teorija buvo varijuojama ir pritaikoma naudojimui skirtingose geografinèse ir kultūrinèse situacijose. Visu pirma Korejoje, kuri geografiškai pozicionuojama kaip „kultūrinis koridorius“ tarp Azijos šalių, ši teorija jau yra senai taikoma ir labai tankiai apgyvendintoms teritorijoms (Hong, Song, Wu 2006). Antroji tradicija - žaliosios jungtys (angl. greenways), želdynų sistemos mieste. Pavyzdžiui, Jungtinèse Amerikos Valstijose jau nuo XIX a. antrosios pusés parkai ir kitos žaliosios erdvės tarnauja kaip fundamentali urbanistinè infrastruktūra, sprendžianti miesto apkrovimo ir sanavimo problemas. Amerikoje šios srities pradininkas buvo F. L. Olmstedas. (Yu, 2010:61). Europoje, tam tikra prasme, kraštovaizdžio urbanistikos pradininkai buvo Paryžiaus miesto reformatoriai G. E. Haussmannas (1809-1891), J. C. A. Alphandas (1817-1831), E. Belgrandas (1810-1878), su jais dirbę kraštovaizdžio architektai J.-P. Barillet-Deschamps (1824-1873), E. André (1840-1911). Trečioji tradicija - žalieji žiedai, juostos (angl. greenbelts), kaip miestą struktūrizuojanti kraštovaizdžio sistema, plačiai paplitusi Europoje XVIII-XIX amžiuje pertvarkant miestustvirtoves, jų gynybines sienas paverčiant viešais parkais ir sodais. (Yu 2010). Šių pertvarkymų tvarumo pavydžiais galètų būti iki šiol savo vaidmenị atliekantys mums gerai žinomi Rygos, Krokuvos, Liuksemburgo, Oslo ir kitų miestų sodai, irengti naujai paskirčiai pritaikant gynybinius ịtvirtinamus. Trečiajai tradicijai priskiriamos ir E. Hovardo (1850-1928) pasiūlytos miesto-sodo idejos. Visą amžių E. Hovardo miesto-sodo struktūrinis modelis padèjo ir planuojant didelius miestus, ieškant „gerų urbanistinių formų“. Pavyzdžiui Londono ir Berlyno žaliosios juostos, kurios padeda išlaikyti miesto kompaktiškumą, arba ,žalioji širdis“, padedanti formuoti miesto branduoli, ,„̌̌alieji pleištai“, padedantys kontroliuoti miesto plètrą ( $\mathrm{Yu}$ 2010). Ketvirtoji tradicija - ekologinis tinklas (angl. ecological network), kuriame kraštovaizdis yra svarbus biologinius procesus apsaugantis elementas. Lietuvos gamtinio karkaso samprata savo esme atitinka 
šią tradiciją. Amerikos mokslininkas biologas Edward Wilson yra pasakęs, kad kraštovaizdžio urbanistikos ideologijoje kraštovaizdžio projektavimas turès lemiamą vaidmeni. Labiausiai apgyvendintuose kraštovaizdžiuose biologinè ịvairové gali būti išlaikoma dèl išradingo medžių grupių, gyvatvorių, vandens seklumų, rezervuarų, dirbtinių tvenkinių ir ežerų išdèstymo. Generaliniai planai lems ne tik ekonominį efektyvumą ir grožį, bet ir tai, kaip bus apsaugotos biologinès rūšys ir veislès (Yu 2010). Gamtos apsaugos filosofija keičiasi nuo atskirų rūšių ar teritorijų apsaugos, link koncepcijos, orientuotos ị ekosistemų kūrimą, pabrèžiant stipriai integruotos apsauginès infrastruktūros reikšmę. Igyvendinant šią koncepciją kraštovaizdžio metodai tampa ypatingai svarbūs. Skirtingai nuo kitų disciplinų, kraštovaizdžio metodas pateikia holistines vertinimo ir planavimo priemones apibrèžiant ir vystant sąsajas tarp gamtos ir kultūros. Kraštovaizdis, kaip gamtos ir žmogaus sąveikos vieta, pasirodo galintis būti tvarumo šerdimi. Kraštovaizdžio, kaip heterogeniškos teritorijos, sudarytos iš tarpusavyje veikiančių ekosistemų klasterių, apibrěžimas yra fundamentalus ta prasme, kad jis kraštovaizdžio architektūros discipliną pakelia ị mokslinị lygị (Yu 2010). Penktoji tradicija - ekologinè infrastruktūra ir ekosistemų paslaugos (angl. ecological infrastructure and ecosystems services) kraštovaizdį kviečia suvokti kaip integruotą miesto ar krašto tvarumo infrastruktūrą.

Ekologinė infrastruktūra, kaip ištobulinta ekologinio tinklo versija, turi prasmingiausią išraišką ir suvokiama kaip svarbi strategija siekiant igyvendinti tvarumo sąlygas sukurtuose kraštovaizdžiuose, metropolijų zonose ir miestuose. Pagal galiojančius dokumentus, ekologinès infrastruktūros terminas atsirado UNESCO programoje MAB (angl. Man and Biosphere, liet. „Žmogus ir biosfera"). 1984 m. MAB ataskaitoje buvo suformuluoti penki principai: (1) ekologinis išsaugojimas (angl. ecological conservation), (2) ekologinè infrastruktūra (angl. ecological infrastructure), (3) gyvenamosios vietos standartai (angl. living standards of residence), (4) kultūrinis ir istorinis išsaugojimas (angl. cultural and historical conservation), (5) gamtos mieste suaktyvinimas (angl. induction of nature into cities) (Yu 2010). Pasak kinų mokslininko, daugiausia šioje srityje yra pasiekę Nyderlandai, kurie turi gerų pavyzdžių, kaip Nyderlandų pagrindinè ekologinè infrastruktūra (angl. Dutch Ecological Main Infrustructure), sudaryta iš pagrindinių (šerdinių) gamtinių teritorijų, gamtinès plètros teritorijų, koridorių, jungčių ir buferinių zonų. Ekologinès infrastruktūros koncepcija tampa dar galingesne priemone kraštovaizdžio urbanistikoje, kai jos išmanymas sujungiamas su supratimu apie ekosistemų paslaugas. Identifikuojamos penkios šių paslaugų kategorijos: aprūpinimas, susijęs su maisto produkcija ir švariu vandeniu; reguliavimas, susijęs su klimato ir ligų kontrole; tarpininkavimas sprendžiant potvynių klausimus; palaikymas, susijęs su laukinės floros ir faunos buveinèmis; kultūrinè paslauga, susijusi su dvasine ir rekreacine nauda (Yu 2010). Penkios profesoriaus K. Yu ịvardintos bei aptartos tradicijos ir idè- 
jos apie kraštovaizdžio infrastruktūrą ir kraštovaizdžio urbanistiką yra vieningos bendrai suprantant gamtinị kapitalą ir ekosistemų paslaugas ir yra sujungiamos ekologinès infrastruktūros koncepcijoje. Kiti kraštovaizdžio elementai, kaip kultūros paveldo teritorijos, pakrančių buferiai, lietaus vandens valdymo sistemos, gali taip būti integruoti ị ekologinę infrastruktūrą.

1994 m. Danijoje, Aalborgo mieste priimtą Europos miestų darnaus vystymosi chartiją pasirašè daugiau nei 200 miestų (Charter...1994). Vilniaus miestas $2004 \mathrm{~m}$. taip pat prisijungè prie šios chartijos. Tai reiškia, kad ir Lietuva yra ịsipareigojusi laikytis svarbiausios šiuolaikinèje urbanistikoje darnios plètros krypties. Śie įsipareigojimai skatina vadovautis principais, kurie nurodo, kad planuojant valstybès, apskričių, savivaldybių ir miestų teritorijas ilgalaikèje perspektyvoje būtina ịvertinti socialinius, ekonominius, ekologinius ir kultūrinius išteklius, kurie yra riboti ir dažnai neatkuriami. Socialinès ir teritorinès raidos plotmejje būtina didesnè miesto planuotojų, urbanistų, architektų, ekonomistų, ekologų, kraštovaizdžio specialistų sanglauda. Urbanistinè doktrina privalo turèti socialinès raidos humaniškajj užtaisą, ji turi būti rengiama, svarstoma ir analizuojama bendrame ekonominès ir socialinès politikos, ekosistemos išteklių naudojimo politikos kontekste.

Lietuvos Respublikos Vyriausybė 2003 m. patvirtino pirmąą Nacionalinę darnaus vystymosi strategiją, kuri, atsižvelgus ị ES reikalavimus, buvo pakeista (atnaujinta) $2009 \mathrm{~m}$. Strategijos 7 punktas apibrèžia pagrindinius visos Lietuvos darnaus vystymosi siekius, iš kurių vienas tiesiogiai susijęs su ekologija: , $<\ldots>$ neviršyti ES leistinų normatyvų, laikytis tarptautinių konvencijų, ribojančių aplinkos taršą ir poveikị pasaulio klimatui, reikalavimų“. Be to, strategijoje suformuluoti darnaus vystymosi prioritetai ir principai, tikslai ir uždaviniai bei pateiktas nacionalinių darnaus vystymosi rodiklių sąrašas. Atsižvelgiant ị ES deklaruojamą darnų vystymąsi, LR teisès aktuose formaliai ịtvirtinta darnaus vystymosi koncepcija, tačiau faktiškai esminis dėmesys nacionaliniuose teisès aktuose skiriamas procedūroms ir biurokratiniam veikimo mechanizmui išaiškinti (Staniūnas 2013). Tiesiogiai ar netiesiogiai teisès aktuose dažnai ịtvirtinta bent viena darnaus vystymosi sudètinè dalis, todèl, vertinant bendrą vaizdą ir nesigilinant ị detales, darnios plètros požiūriu LR planavimo dokumentai atitinka ES pageidaujamą kryptị. Problemos ryškèja detaliau paanalizavus, kas yra nuveikta vietos valdžios, kad miesto ekologija (darnaus vystymosi sudètinė dalis) igautų konkrečią kryptị ir rodiklius. Kaip teigia Mindaugas Staniūnas, „teisès aktuose imperatyviai kartojamas darnios plètros siekimas, tačiau miestų planavimą reglamentuojančiuose dokumentuose remiamasi aptakiomis, nekonkrečiomis politinio tipo frazėmis, o miesto ekologijos termino ir (arba) sudètinių dalių struktūros išaiškinimo teisès aktuose apskritai nèra" (Staniūnas 2013).

Lietuvos architektai, urbanistai, kraštovaizdžio architektai ir kiti miesto planuotojai ir projektuotojai nelieka naujų miesto planavimo iššūkių nuošalëje. 
Vienas iš pagrindinių diskusijų ir naujų idejjų sklaidos priemonių yra konferencijos ir forumai. $2007 \mathrm{~m}$. startavęs pirmasis Urbanistinis forumas „Lietuvos darnios erdvinès plètros sistemos kūrimas“ būtent ir buvo skirtas darnos miestų planavime problemai nagrinèti. Kaip teigia vienos pagrindinių urbanistinių forumų organizatorių Dalia Bardauskienė ir Marija Burinskienè, Lietuvos urbanistinio forumo atsiradimui impulsą suteikè ne tik tarptautinès gairès, bet ir $2006 \mathrm{~m}$. pasirašytas memorandumas „Lietuvos perspektyva 2007-2013 metais. Planavimas, urbanistika, architektūra ir statybos kultūra“. 2006 m. memorandumą pasirašè Aplinkos ministerija, Lietuvos architektų sajunga, Lietuvos nekilnojamojo turto plètros asociacija, Lietuvos statybininkų asociacija. Memorandumo partnerių iniciatyva $2007 \mathrm{~m}$. suburta darbo grupé prie Aplinkos ministerijos, kuri nustatè Urbanistinio forumo tikslus ir uždavinius, pirmosios konferencijos koncepciją ir ją organizavo (Bardauskienè, Burinskienè 2013).

Akivaizdu, kad Lietuvoje darniosios plètros principus atitinkančia, t. y. ,žaliaja“, urbanistika turètume vadinti „rudają“ urbanistiką (Environmental Law Institute 2009). Bendruosiuose planuose turètume orientuotis ị jau užstatytų, nualintų (devastuotų) urbanistinių teritorijų atgaivinimą, skatinti konversiją, o ne plyno lauko investicijas. Tik taip galèsime užtikrinti ekonomini savo miestu gyvybingumą ir ekologinę jų aplinkos pusiausvyrą (Pakalnis; Bardauskienė 2013). Tvaraus miesto klausimus nagrinejo ir šia tema pasisakè E. Staniūnas (2011), M. Staniūnas (2012; 2013), G. Stauskis (2011; 2016; 2018), S. Čereškevičius (2013), M. Pakalnis (2013), D. Bardauskienė (2010; 2013), M. Burinskiené (2010; 2013), P. Juškevičius $(2005 ; 2013)$ ir kiti mokslininkai bei praktikai.

\subsection{Kraštovaizdžio ir urbanistikos sąveikos moksliniai tyrimai ir taikomos metodikos}

\subsubsection{Tyrimų temos ir aspektai}

Ilgą laiką Lietuvos autorių kraštovaizdžio estetinio potencialo tyrimai plètojosi percepcinès (meninès) analizès kryptimi. Šios krypties tyrimai turi tvirtą metodologini pagrindą ir stuburą. Suvokiama, kad be tokios meninès kraštovaizdžio sampratos estetinis vertinimas negali būti išsamus. Žinoma, formuojant estetinio potencialo prielaidas kartu turètų būti vertinami ir aplinkosaugos, ekonominiai, socialiniai aspektai (Kavaliauskas 2013). Tyrimų metodika visada sietina su nagrinejjamos teritorijos masteliu (nacionaliniu, regioniniu ir lokaliu), nes percepcinès analizès metodika lokaliu ir regioniniu lygmeniu iš esmès skiriasi. Regioninis lygmuo analizuoja kraštovaizdžio sandaros raiškumą, struktūros ịvairovę, panoraminių reginių potencialą, vizualinị atsparumą ir panašius kraštovaizdžių 
estetinès vertès kriterijus. Tuo tarpu lokaliu lygmeniu estetinio potencialo tyrimas orientuosis ị lokalius estetinius kriterijus ir rodiklius.

Lietuvoje estetiniam kraštovaizdžio vertinimui pagrindus dèjo K. Ėringis (2000; 2005), A. R. Budriūnas (2000), P. Kavaliauskas (1974; 2011, 2013; 2014), G. Daniulaitis (1970; 1999), M. Purvinas (1983), J. Bučas (2001), V. Stauskas 1966; 2001) ir kiti mokslininkai. 1968 m. K. Ėringis ir R. Budriūnas sudarè pirmaji Lietuvos kraštovaizdžio estetinių išteklių žemélapį. 1970 m. G. Daniulaitis ir P. Kavaliauskas atliko kraštovaizdžio estetinio vertinimo tyrimus, nustate Lietuvos žemyninių rekreacinių teritorijų kraštovaizdžio estetinius tipus ir juos vizualizavo. Autoriai taip pat pateike estetiniu potencialu besiskiriančių kraštovaizdžių vizualinių tipų seką. 1974 m. P. Kavaliauskas atliko kraštovaizdžio rekreacinio bonitavimo sistemų metodinę apžvalgą, išskirdamas keturis metodus: integralinị, diferencialinị, bendraji kraštovaizdžio geografijos metodą ir taikomaji kraštovaizdžio geografijos metodą. 1983 m. M. Purvinas tyrimuose išryškino vizualinių ryšių ir erdvių kaitos svarbą, pateikè vizualinių erdvių hierarchiją, sukūrè metodiką gamtinès aplinkos psichologiniams ir estetiniams ištekliams nustatyti. 1988-1992 m. J. Bučas tyrè erdvinès kraštovaizdžio struktūros kompozicinę sandarą, analizuodamas želdynų, užstatymo, kelių ir kitų struktūrų sąveikos apraiškas, ieškojo, nuo ko priklauso estetinė kraštovaizdžio kokybè. $2011 \mathrm{~m}$. plètodamas percepcinio (meninio) tyrimo metodologiją, P. Kavaliauskas pateikia kraštovaizdžio emocinio suvokimo proceso analizès schemą (Kavaliauskas 2011), kurioje demonstruojami visi svarbiausi etapai, per kuriuos realaus kraštovaizdžio savybių jutiminis poveikis atsispindi mūsų pasąmonèje. Plačiai kraštovaizdžio estetinio potencialo tyrimų Lietuvoje raidą ir principus bei metodikas apžvelgė doktorantė D. Kalkė (2014; 2015).

2013 m. Lietuvos Respublikos aplinkos ministerijos užsakymu autorių kolektyvo parengtose "Kraštovaizdžio formavimo gairèse valstybiniams keliams ir geležinkeliams" sutelkta daug metodinès informacijos apie šių svarbių judejjimo linijų trasuotės poveiki kraštovaizdžiui ir kraštovaizdžio poveikị keliaujantiesiems (Kraštovaizdžio... 2013). Klaipėdos universitete ir Kauno technologijos universitete J. Abromas atliko vèjo elektrinių vizualinio poveikio kraštovaizdžiui vertinimą ir apgynè technologijos mokslų daktaro disertaciją „Vejjo elektrinių vizualinio poveikio kraštovaizdžiui vertinimas“ (Abromas 2015). Lietuvos Respublikos aplinkos ministerijos užsakymu $2015 \mathrm{~m}$. buvo parengta „Vizualinès taršos gamtiniams kraštovaizdžio kompleksams ir objektams nustatymo metodika“ (Kamičaitytè-Virbašienè et al. 2015). Metodikoje pateikta vizualinès taršos samprata, vertinimo metodai, techniniai reikalavimai tokiai taršai nustatyti, apžvelgta užsienio šalių patirtis šioje srityje, aptariami teoriniai ir praktiniai pavyzdžiai, kaip nustatyti ir apskaičiuoti neigiamą vizualinị poveikị ar žalą kraštovaizdžiui (Vizualinès taršos gamtiniams... 2015). 
Vytauto Jurkšto sudaryta urbanistinės kompozicijos ir jos vizualinio suvokimo tyrimų metodika (Jurkštas 1994) apima silueto ir panoramų bei miesto viešujų erdvių kompozicijos analizę. Miesto ịvaizdžio tyrimo ir formavimo galimybes savo disertacijoje nagrinejjo Salvinija Kirvaitienė (2007). Urbanistikos klausimus ir problematiką kraštovaizdžio kontekste nagrinejo Zigmas Daunora (2004); Jurgis Vanagas (2006), Algimantas Mačiulis (2006,); Inesa Alistratovaitè-Kurtinaitienè (2013); Dalia Dijokienė (2013) ir kiti autoriai. Justinas Bučys savo daktaro disertacijoje „Miesto lokalių centrų funkcinès ir kompozicinès struktūrų sąveika“" (2013) nagrinèjo lokalių didmiesčio centrų funkcinès ir kompozicinès struktūrų sąryšio ypatumus. Daugeliui šių urbanistinių analizių būdinga tai, kad jose miesto atviros erdvès nagrinèjamos neužsimenant apie kraštovaizdžio architektūros reiškinį. Dalis Lietuvos mokslininkų atlieka hermeneutinę miesto kraštovaizdžio analizę. Pavyzdžiui, Kęstutis Zaleckis (2011) kraštovaizdị analizuoja $^{5}$ kaip kultūrini tekstą; Vytautas Petrušonis (2010) tiria kraštovaizdžio sociokultūrinị kontekstą ir kelia vietos tapatumo klausimus. Agnė Ivanauskaitė (2015), nagrinèdama miesto urbanistinès formos sampratą ir jos taikymo galimybes Lietuvoje, pasigedo urbanistikos terminų bazès, todèl pasiūlè platų tokių sąvokų spektrą.

Vladas Stauskas (1932-2014) su bendradarbiais pasiūlè architektūrinès aplinkos kokybès vertinimo kriterijus (eilès tvarka): turinys; forma; turinio ir formos santykis; santykis su aplinka; inžineriniai ir ekonominiai sprendiniai (Grecevičius et al. 2013). Šią idèją ir kriterijų seką sèkmingai plètojo rekreacinès architektūros specialistai Petras Grecevičius (1985), Jūratė Tutlytė (2001), Eugenijus Staniūnas ir Gintaras Stauskis (2011), kiti autoriai. Miesto planinèserdvinès ir estetinès-meninès raidos, kraštovaizdžio architektūros tyrimams ir tyrimų metodikai svarbūs yra amerikiečių urbanisto K. Lynch darbai ir publikacijos (Lynch 1960, 1972, 1984). Pastaruoju metu populiareja Arizonos (JAV) universiteto profesorès Nan Ellin (2006) pasiūlyta nauja miesto integralumo teorija, kurios pamatinè sąvoka - tèkmé, gamtą pripažįstant urbanistikos modelio pagrindu (Ellin 2006; Samalavičius 2013). Tom Turner, vienas iš moderniausių kraštovaizdžio urbanistinių ideologų, rašė: „Ateities miestas bus begalinès kraštovaizdžių serijos: psichologinès ir fizinès, miesto ir kaimo, besiplečiančios ir susiliejančios. Jos bus specialiai planuojamos, o rezultatai ịrašomi i geografines informacines sistemas (GIS), kurių dẻka galima išgauti daugybę planų, vaizdų ir kitų įrašųu“ (Turner 1996; Stauskis 2016). 1996 m. išleista T. Turner knyga City as Landscape (liet. „Miestas kaip kraštovaizdis“) skatina naują alternatyvų, arba, kaip jis pats ịvardija, ,post-postmodernistinị“ požiūrị i ̣ miesto planavimą ir pro-

\footnotetext{
${ }^{5}$ Minètų mokslininkų darbuose dažniausiai kalbant apie kraštovaizdị mieste vartojamas miestovaizdžio terminas.
} 
jektavimą. G. Stauskis ir F. Eckardt (2011) pateikia viešosios erdvės formavimo modelị, kuris skatina žmonių tarpusavio ryšius ir socialinę integraciją bei erdvių naudojimą. Modelio esmè - keturių pagrindinių zonų viešojoje erdvejje išskyrimas: „užkulisių“, „scenos“, „žiūrovų“ ir „praeivių“. Didesnèse ir intensyviau naudojamose erdvèse gali būti numatytos ir kelios „scenos“. „Pasirodymo“ veiklos gali būti labai ịvairios: pradedant ramiu pasisėdèjimu, pokalbiu ir baigiant fiziniais pratimais, važiavimu dviračiu, šokiu ir pan. „Stebètojų“ zonai labai svarbus geras vizualinis ryšys su „scena“, optimalus dydis (stebètojai joje turi jaustis jaukiai ir saugiai) bei mikroklimatinès sąlygos (apsaugota nuo vejjų, tiesioginès saulès, lietaus ir pan.), geras lauko baldų išdèstymas. „Praeivių“ zona turi būti atskirta nuo „scenos“ ir „stebètojų“ zonų, tačiau turèti su jomis vizualinị ryši ir užtikrinti tranzitinio ryšio funkcionalumą. Tokio modelio taikymas tyrimuose padeda atlikti integralesnę analizę ir atskleisti ne tik funkcinę, bet ir erdvinę konkrečios vietos struktūrą (Stauskis et al. 2011).

Vis labiau įsigali socialinès dimensijos akcentavimas architektūrinès aplinkos formavimo ir pertvarkymo, ypač urbanistikos, tuo pačiu ir kraštovaizdžio architektūros, srityje. Apie tai kalba Lietuvos ir užsienio mokslininkai (Jacobs 1961; Mumford 1960; Lynch 1960, 1972, 1984; Grunskis 2002; Vanagas 2003; Gražulevičiūtè-Vileniškè 2010, 2014; Stauskis ir Eckard 2011; Grecevičius et al. 2013; Jakaitis 2013; Samalavičius 2013; Kamičaitytė-Virbašienè et al. 2015). Naujų izžvalgų nuolat pateikia ir želdynų, kaip socialinės infrastruktūros sando, įtaką mieste aptaria kraštotvarkos specialistė Indrè Gražulevičiūtè-Vileniškè (2010; 2013). Ji išskiria penkis miesto socialinès aplinkos ir želdynų sąveikos aspektus: sistemini, ekonominị, rekreacini, socialinès sanglaudos skatinimo arba demokratinès visuomenès formavimo ir kultūrinị. 2014 metais mokslo žurnale „Tiltai“ I. Gražulevičiūtè-Vileniškè išsamiai aptarè sociologinių urbanizuotos aplinkos tyrimų objektą, tikslus ir sandus (struktūrines sudètines dalis), akcentuodama jų reikšmę, platų tyrimų spektrą ir objektų bei metodų ịvairovę, sintezuodama kitų autorių patirtị ir tyrimų kryptis. Ji pabrēžè, kad tyrimų objektais gali būti vizualioji miesto aplinkos raiška, urbanizuotos teritorijos funkcionavimas, socialinè sudètis ir jos kaita, kultūrinis, socialinis, ekonominis urbanizuotos aplinkos potencialas. Šių tyrimų objektų grupių tikslų galima siekti taikant ịvairius metodus - kraštovaizdžio estetikos ir vizualiosios raiškos tyrimams taikomas stebėjimas, ekspertinis vertinimas ir visuomenès apklausos; funkcionavimo, socialinès sudèties ir jos kaitos tyrimams gali būti taikomas stebèjimo metodas ir apklausos; urbanizuotos aplinkos raidos potencialo tyrimams galima taikyti metodus nuo interpretacijos iki struktūruoto stebejjimo ir anketinių apklausų (Gražulevičiūtè-Vileniškè 2014).

Nagrinėjant kraštovaizdžio architektūros ir urbanistikos sprendinių sąveiką išlieka svarbus ekonominio naudingumo aspektas. Tikslingumas, kaip kraštovaizdžio architektūros objektų vertinimo kriterijus, pabrèžiamas kraštovaizdžio 
architekto R. Pilkausko publikacijose ir darbuose (Pilkauskas 2007). Tai gali būti reikšmingas sociokultūrinio ir ekonominio vertinimo pagrindas. Pasak turto vertintojų, artimiausios ateities uždavinių sąraše turètų būti kuriamų ar sukurtų želdynų - parkų, skverų - ekonominès vertès nustatymo metodikos parengimas. Kol kas toks želdynas yra vertybė, viešoji gèrybè, kuri, esant neapibrěžtam nuosavybès ir naudojimo statusui, nèra laikoma investiciniu objektu ar investicija (Galinienè ir Deveikis 2011; Deveikis 2013). Miesto žaliosios infrastruktūros kaina ir verte dažniausiai skaičiuojama pagal jos suprojektavimo, irengimo ir priežiūros kainą. Šiuo metu visuomenè ima suvokti ekosistemų išteklių ir jų funkcijų ekonominę naudą ir vertę (Deveikis 2013). Pasaulyje ir Lietuvoje stengiamasi rasti būdų, kaip tinkamai parkų ir kitų žaliujų erdvių sukuriamą vertę išreikšti piniginiais vienetais. Vertinant parkus, tradiciniai turto vertinimo metodai netinka, todèl mokslininkai naudojasi atskleistų preferencijų metodais (Lazdinis et al. 2011). Nuosekli ekosistemų išteklių ir jų funkcijų - kapitalo, paslaugų ir nenaudojimo - verčių nustatymo metodų bei pačių išteklių pažinimo analizè pateikiama Mykolo Romerio universiteto autorių parengtoje monografijoje (Lazdinis et al. 2012). Ekosistemų teikiamą naudą (kartu ir vertès pagrindą) ekonomistai suskirste ị tris plačias kategorijas: 1) tiesioginè nauda; 2) netiesioginė nauda; 3) pasyvioji nauda (Deveikis 2013). Ekosistemų išteklių netiesioginio naudojimo ir nenaudojimo vertès bendrosios ekonominès vertès struktūroje gali būti nustatomos vartotojų pasirinkimo vertès nustatymo, kontingento vertinimo ar hedoninių kainų metodais (vertès nustatymo būdais). Hedoninių vertės nustatymo metodų ar būdų, modelių grupejje išskirtini šie vertès skaičiavimo ar pagrindimo modeliai: kelionès išlaidų, nekilnojamojo turto kainų palyginimo, gèrybès lankomumo analizės (Lazdinis et al. 2012). Hedoninio pasirinkimo motyvai nulemia gražaus, patrauklaus kraštovaizdžio vietų (paežerių, parkų ir pan.) kotiravimą ir vertès augimą rinkoje (Deveikis 2013). Hedoninio ịkainojimo metodas taikomas nustatant gamtinès aplinkos paslaugų, kurios tiesiogiai daro ịtaką kokio nors produkto rinkos kainai, vertei. Metodas gali būti taikomas, nustatant ekonominę naudą, susijusią su gamtinès aplinkos kokybe (oro ir vandenų tarša, triukšmas ir kt.) bei su gamtinès aplinkos malonumais (estetiniai vaizdai, rekreacinių vietovių artumas ir kt.). Hedoninio įkainojimo metodo bazinè prielaida yra ta, kad prekių rinkos kainai daro ịtaką jų požymiai. Šis metodas dažniausia taikomas vertinant aplinkos naudą, kuri daro įtaką gyvenamujų namų kainai (Mizaras 2011). Hedoniniai modeliai vis labiau populiarejja, siekiant ịvertinti aplinkos teikiamą poveikị gyvenvietėms. Miestuose palikti neužstatyti plotai, ịskaitant žalias zonas, vandens telkinius ir miesto aikštes, suteikia gyventojams patogumų ir rekreacijos, o tai prisideda prie gyvenimo kokybės miestuose. Ekonominis miesto laisvų (neužstatytu) plotų vertinimas padeda miesto planavimui, gamtos saugojimui ir vystymui. Kadangi nėra rinkos, kurioje gali būti ịvertinama miesto laisvujų zonų nauda, hedoninis modelis tapo tinkamu nustatyti ryši tarp būsto kainų ir ịvairių 
charakteristikų, įtraukiant aplinkos elementus (Lazdinis et al. 2012). Urbanistikos ir kraštovaizdžio architektūros sprendinių sąveikos ekonominio naudingumo aspektu įdomi yra $2010 \mathrm{~m}$. JAV išleista miesto žaliųjų erdvių ekonominių tyrimų medžiaga „Atvirujų erdvių ekonominè nauda, rekreacinès paslaugos ir judrios visuomenès projektas" (angl. The Economic Benefits of Open Space, Recreation Facilities and Walkable Community Design). Labai panašus požiūris ị planavimo principus pateikiami E. Ramanausko mokslų daktaro disertacijoje „Lietuvos kultūrinio kraštovaizdžio formavimo raida ir jo erdvinio optimizavimo prielaidos (1918-2008)“, kurioje autorius, apibendrindamas savo tyrimą ir teikdamas siūlymus dèl kraštovaizdžio optimizavimo, teigia, kad vienas pagrindinių teritorijų planavimo principų turètų būti esamų žemès sklypų konsolidavimas bei teritorijų planavimo sprendinių rengimas nepriklausomai nuo esančių žemės sklypų struktūros. Tokią vientisą teritoriją siūloma vadinti konsoliduotu teritoriniu vienetu. Siekiant realaus ir efektyvaus konsoliduoto teritorinio vieneto planavimo kaip neatskiriamus jo aspektus siūloma apibrèžti techninius-socialinius bei kompozicinius reikalavimus (Ramanauskas 2011).

Pastaruoju metu, ypač užsienio mokslinèje literatūroje, gausiai sutinkama miesto žaliųjų teritorijų poveikio žmogaus sveikatai tyrimų. İdomūs ir perspektyvūs Lietuvos ir užsienio mokslininkų bendri tyrimai pristatomi keliuose mokslinių sveikatos tyrimų žurnaluose. Pavyzdžiui, žurnale „BioMed Research International" straipsnyje The Effect of Park and Urban Environments on Coronary Artery Disease Patients: A Randomized Trial (liet. „Parko ir miesto aplinkos poveikis koronarinių arterijų ligoms sergantiems pacientams: atsitiktinis bandymas") skelbiami širdies ligu ryšio su žaliaja miesto aplinka tyrimų rezultatai ir teigiama, kad duomenys parodè, kad reguliarūs 30 min. pasivaikščiojimai parke, atliekami septynias dienas iš eilès, paskatino geresnius ligonių ramybès pokyčius, prailginimo toleranciją ir pratybu trukmę, lyginant su lygiagrečiais pasivaikščiojimais miesto aplinkoje. Pasivaikščiojimas parke taip pat padidino pacientų atsigavimą po kasdienio fizinio krūvio. Rezultatai patvirtina hipotezę, kad pasivaikščiojimas parko aplinkoje turi geresni atkuriamaji poveiki sutrikusiai termodinamikai, palyginti su vaikščiojimu intensyvaus miesto gatvejje (Gražulevičienè et al. 2015). Kitame mokslo žurnale „International Journal of Environmental Research and Public Health“" (2014), skelbiami JAV mokslininkų kolektyvo K. M. M. Beyer; A. Kaltenbach; A. Szabo; S. Bogar; F. J. Nieto; K. M. Malecki tyrimai straipsnyje Exposure to Neighborhood Green Space and Mental Health: Evidence from the Survey of the Health of Wisconsin (liet. „Kaimynijos žaliosios erdvès poveikis psichinei sveikatai: Viskonsino sveikatos priežiūros stebejjimo rezultatai“). Straipsnyje teigiama, kad aukštesnis kaimynijų žaliųjų erdvių lygis yra susijęs su žymiai mažesniu depresijos, nerimo ir streso simptomų lygiu. Rezultatai rodo, kad ekologiškumas gali būti JAV psichinès sveikatos gerinimo strategija (Bayer et al. 2014). Tame pačiame žurnale prista- 
tomi tyrimai ir apie želdynų įtaką vaiko vystymuisi ir sveikatai. Tarptautinis mokslininkų kolektyvas tyrimo išvadas pateikia straipsnyje Impact of Residential Greenness on Preschool Children's Emotional and Behavioral Problems (liet. „Gyvenamosios aplinkos želdynų poveikis ikimokyklinio amžiaus vaikų emocijų ir elgesio problemoms"). Išvadose teigiama, kad nepriklausomai nuo motinų išsilavinimo, vaikų psichinè sveikata yra susijusi su gyvenamosios vietos atstumu nuo miesto parko - kuo arčiau parko, tuo mažiau problemų. Šie rezultatai yra svarbūs visuomenès sveikatos srityje, siekiant paremti ekologišką miestų planavimo politiką ir užkirsti kelią vaikų psichinès sveikatos problemoms (Balsevičienè et al. 2014).

Rekreacijos problematiką nagrinèja E. Staniūnas ir G. Stauskis knygoje „Rekreaciniai kompleksai gamtinèje aplinkoje“ (2011). Kraštovaizdžio, kaip miesto rekreacinio potencialo svarbą, nagrinèjo I. Urbonaitė mokslų daktaro disertacijoje „Rekreacinių funkcijų raiška Vilniaus miesto erdvinèje struktūroje“ (2013). Savo darbe mokslininke teigia, kad „tvarios miesto rekreacinès sistemos formavimas sietinas ne tik su gamtinių rekreacinių išteklių saugojimu, gyvenimo kokybės gerinimu kuriant patrauklią rekreacinę miesto aplinką, gerinant pasiekiamumo galimybes, bet ir su tinkamu tos sistemos koordinavimu“. Autorès manymu, naujausios miestų gaivinimų programos remiasi kraštovaizdžio strategjų principu rekreacines funkcijas naudoti kuriant naujai formuojamų ar regeneruojamų teritorijų turinį. Kraštovaizdžio tvarkymo principais grịstos rekreacinès teritorijos veikia sinergiškai, sukurdamos traukos ryšius ir aktyvuodamos plètojamas teritorijas. Šis metodas sékmingai taikomas devastuotoms teritorijoms gaivinti tiek miesto vidinejje struktūroje, tiek ir užmiesčio sąvartynų, kasyklų ir kitos didelès apimties pramonès teritorijoms (Urbonaitė 2013).

Miesto ekologijos klausimus gana plačiai nagrinèja Mindaugas Staniūnas savo technologijos mokslų daktaro disertacijoje „Ekologijos aspekto vertinimas miestų bendruosiuose planuose“". Ekologija, būdama darnaus vystymosi koncepcijos dalis, yra sulaukusi didelio specialistų dèmesio ir ateityje jai skiriamas dèmesys turètų didèti, nes šiuo metu ji vis dar atsilieka nuo ekonominio ir socialinio darnaus vystymosi koncepcijos komponentų (Staniūnas 2013). M. Staniūno disertacijos ịžvalgos ir konkretūs siūlymai dèl kiekybinių ekologinio kompensavimo rodiklių, gali pasitarnauti tiriant kraštovaizdžio architektūros ir urbanistinių veiklų bei sprendinių sąveikos galimybes. Pavyzdžiui, viena iš populiariausių kompensavimo priemonių, susijusių su klimato atšilimu, yra medžių sodinimas (Staniūnas 2013). Miesto želdynų ir želdinių urboekologinę funkciją nagrinèjo ir apibendrino K. Jakovlevas-Mateckis savo monografijos „Miesto kraštovaizdžio architektūra“ I tome (Jakovlevas-Mateckis 2008). Kaip urboekologinès funkcijos siejasi su technine apsaugine bei architektūrine socialine funkcija, pateikiama 1.1 lentelèje. 
1.1 lentelè. Svarbiausios kraštovaizdžio architektūros objektų funkcijos. Šaltinis: Jakovlevas-Mateckis, 2008

Table 1.1. The most important functions of landscape architecture objects. Source: Jakovlevas-Mateckis, 2008

\begin{tabular}{|c|c|c|}
\hline \multicolumn{3}{|c|}{ Urboekologinė funkcija } \\
\hline Oro sudèties reguliavimas & Mikroklimato gerinimas & $\begin{array}{l}\text { Oro užterštumo mažini- } \\
\text { mas }\end{array}$ \\
\hline Oro sudèties gerinimas & $\begin{array}{l}\text { Oro temperatūros regulia- } \\
\text { vimas, vertikaliujų srovių } \\
\text { sudarymas }\end{array}$ & $\begin{array}{l}\text { Oro užterštumo dujomis } \\
\text { mažinimas }\end{array}$ \\
\hline $\begin{array}{l}\text { Mikrobu ir bakterijų nai- } \\
\text { kinimas }\end{array}$ & $\begin{array}{l}\text { Oro drègnumo reguliavi- } \\
\text { mas }\end{array}$ & $\begin{array}{l}\text { Oro užterštumo aerozoliu } \\
\text { mažinimas }\end{array}$ \\
\hline Oro jonizavimas & $\begin{array}{l}\text { Vèjo greičio mažinimas, } \\
\text { rūkų išsklaidymas }\end{array}$ & $\begin{array}{l}\text { Oro užterštumo dulkèmis } \\
\text { mažinimas }\end{array}$ \\
\hline \multicolumn{3}{|c|}{ Techninė apsauginè } \\
\hline Triukšmo mažinimas & $\begin{array}{l}\text { Apsauginè intarpų arba } \\
\text { užtvarų funkcija }\end{array}$ & $\begin{array}{l}\text { Apsauga nuo dirvos erozi- } \\
\text { jos ir rekultivacija }\end{array}$ \\
\hline \multicolumn{3}{|c|}{ Architektūrinè socialinè funkcija } \\
\hline $\begin{array}{l}\text { Svarbus elementas kuriant } \\
\text { miesto plano struktūrą, } \\
\text { atskiras jo erdves, formuo- } \\
\text { jant miesto savitumą. }\end{array}$ & $\begin{array}{l}\text { Miesto teritorijų ir jos } \\
\text { dalių ryšys su gamtiniu } \\
\text { karkasu ir užmiesčio kraš- } \\
\text { tovaizdžiu. }\end{array}$ & $\begin{array}{l}\text { Gyventojų rekreacinių } \\
\text { poreikių tenkinimas. }\end{array}$ \\
\hline
\end{tabular}

Kaip teigia Joan Iverson Nassauer, daugiau galvojant apie kraštovaizdị ir norint mokytis iš kraštovaizdžio ekologijos, mes galime rasti tokị urbanistinio ekologinio dizaino požiūrị, kuris skatina vaizduotę ir naujoves tuo pačiu metu, nes tai dažniausiai yra pagrịsta moksliniais tyrimais. Tik kraštovaizdis apima daugybę biogeocheminių ir ekologinių procesų ir yra daugelio rūšių, ịskaitant žmones, buveinė (Nassauer 2012). Tik nauja ekologine morale ir etiška atsakomybe išlaikyti biologinę ir kultūrinę ịvairovę grịsta intervencija gali sukurti socialiai ir ekologiškai tvarius kraštovaizdžius (Batista, Matos 2013). Aplinkos etikos (angl. Environmental ethics) ir ekologinès etikos (angl. Ecological ethics) aspektai miesto planavime ir kraštovaizdžio architektūroje vis plačiau nagrinèjami Hicham-Stéphane Afeissa (2010), Anne Sgard (2010), Ian Thompson (2012), Desidério Batista ir Rute Sousa Matos (2013) ir kitų mokslininkų tyrimuose ir moksliniuose straipsniuose. Lietuvoje ekologinès etikos temą nagrinejja Česlovas Kalenda (1998, 2003) Remigijus Čiegis ir Algirdas Gavenauskas (2005), Jūratė Mackevičiūtė (2007), Indrè Gražulevičiūtè-Vileniškè (2012). 
Miesto ir gamtos santykio tyrimų problematika yra neatskiriama nuo kraštovaizdžių tyrimų problematikos apskritai, susijusios su tokiais šių dienų kraštovaizdžių bruožais, kaip spartūs pokyčiai ir didelis jų mastas, didejjantis kraštovaizdžių sudètingumas, fragmentiškumas tiek fizine, vizualine, ekologine prasme, tiek ir dèl besikertančių ne visada matomų socialinių, kultūrinių, ekonominių ir kitų interesų (Gražulevičiūtè-Vileniškè 2016). XXI a. mokslas ieško kelių, kaip integruoti ịvairių mokslo sričių metodus ir išvadas ypač koncentruojantis ị kraštovaizdị ir jo valdymą, kaip alternatyvų būdą ir požiūrị sprendžiant tvaraus miesto klausimus, atsižvelgiant ị kraštovaizdžio teikiamų paslaugų gausą ir integralumą. Tik integraliu tyrimu ir vertinimu galima įveikti dichotominę kraštovaizdžio architektūros prigimtị. Viena vertus, kraštovaizdžio architektūros objektas visada yra (ir liks) socialiai tarnaujantis gamtinès prigimties objektas. Kita vertus, daugelis tokių objektų yra meno kūriniai.

Kraštovaizdžio architektas - tai vietovès estetinès aplinkos formavimo profesionalas, kuris kurdamas architektūrines erdves integruoja žmonijos šimtmečių patirtį aplinkos planavimo ir projektavimo srityje, pateikia sprendimus, kaip išsaugoti istoriškumą, suderinti įvairias veiklas, suformuoti žmonių rekreacijai tinkamą aplinką, užtikrinti darnų (tvarų) teritorijos vystymąsi. Kraštovaizdžio architektūros tyrimai kaip ir pati kraštovaizdžio architektūra (kraštovaizdžio projektavimas) yra sisteminè veikla, savyje integruojanti socialinius, kultūrinius, ekologinius, meninius, urbanistinius, architektūrinius, technologinius, psichologinius, politinius, ir kt. komponentus. Kraštovaizdžio architektūros tyrimų kompleksiškumas ir integralumas yra būtina gerų ateities sprendinių sąlyga ir prielaida.

Urbanizuoto kraštovaizdžio ir jo komponentų estetinio, sociokultūinio, socioekonominio ir ekologinio potencialo tyrimų srityje dirba Kauno technologijos universiteto mokslininkai Kęstutis Zaleckis (2011; 2014), Irina Matijošaitienė (2012; 2013), Jūratė Kamičaitytė-Virbašienė (2011; 2014; 2015), Indrè Gražulevičiūtè-Vileniškè $(2010 ; 2012 ; 2014 ; 2016 ; 2017)$ ir kiti. Kaip teigia I. Gražulevičiūtė-Vileniškè, ,šiuo metu tokio pobūdžio miesto aplinkos ir kraštovaizdžio tyrimai - stebejjimas ir subjektyvi miesto aplinkos interpretacija, hermeneutinis socialinès miesto aplinkos aiškinimas, miesto, kaip teksto, analizè - užima reikšmingą vietą greta kitu kokybinių ir kiekybinių miesto aplinkos tyrimų metodų“. Neįmanoma tyrinèti socialinio reiškinio be subjektyvaus požiūrio ir interpretacijos, kurie būdingi pačiai žmogaus prigimčiai (Gražulevičiūtè-Vileniškè 2014). Kraštovaizdžio estetikos ir ekologijos dermès klausimus analizavo J. I. Nassauer (1992, 1995), latvių mokslininkès M. Jankevica (2012), M. Veinberga ir D. Zigmunde (2016). Tačiau dauguma mokslinių tyrimų yra nukreipti ị kraštovaizdị bendraja prasme ir kraštovaizdị nagrinėja nesiedami jo su kraštovaizdžio architektūra. 
Socialinis aspektas dažniausiai liečiamas tiriant viešujų erdvių problematiką. Tiesa, estetikos, ekologijos ir socialinio aspektų suderinamumo klausimą kèlè I. Thomson (2000), tai traktuodamas daugiau kaip etinę problemą ir palikdamas atvirą klausimą dėl šių trijų aspektų suderinamumo galimybių (Thomson 2000). Išsamus miesto kraštovaizdžio kokybès vertinimo komponentinis (integralus) modelis, kaip jau minèta, pritaikytas Irano sostinèje Teherane vertinant miesto gamtines viešąsias erdves (Valenjako ir kitų upių slėnius) sociokultūrinio ir ekologinio tvarumo ir darnumo požiūriu ( Barghjelveh; Sayad 2011).

Kraštovaizdị, kaip žmogaus aplinkos suvokimo išraišką nagrinèjantys mokslininkai akcentuoja ịvairius sąveikos aspektus. Tyrèjai ir praktikai, kurie dalijasi šia problema, teigia, kad estetika yra pagrindinis žmonių ir kraštovaizdžio sąveikos aspektas (pvz., Kaplan ir Kaplan 1989). Arizonos (JAV) universiteto mokslininkas Terry C. Daniel teigia, kad vaizdo kokybès samprata kyla iš kraštovaizdžio fizinių požymių sąveikos su stebètojo suvokimu (Daniel 2001). Šis mokslininkas kraštovaizdžio analizès metodus siūlè dalinti ị ekspertų ir stebėtojo suvokimo metodus, pažymėdamas, kad kraštovaizdžio estetinė kokybė kyla dèl jo biofizinių savybių ir stebėtojo suvokimo proceso sąveikos, tačiau skirtumas yra kiekvieno komponento santykinè svarba.

Ekologinès etikos paradigmoje formuojasi ekologinè estetika, kurios dèka žmogus kraštovaizdị patiria kaip aktyvus dalyvis, o ne kaip pasyvus nuotraukos ar kito meno objekto stebetojas. Ekologinè savimonė formuoja estetinę patirtí, kurioje žmogus save susieja su gyvu kraštovaizdžiu. Būtent dèl šios sąveikos mes vystome dialogą su savimi ir su kraštovaizdžiu, kuris mums padeda pažinti save ir savo vietą pasaulyje (Daniel 2001).

\subsubsection{Miesto aplinkos tyrimų metodai}

V. Jurkšto manymu, architektūros kokybei ịvertinti nereikia protingų mašinų: pakanka protingai parengtos, logiškos metodikos, paremtos objektyviu ir subjektyviu architektūros supratimu. Subjektyvumo čia nereikia bijoti, nes neįmanoma vertinti grožio be paties žmogaus požiūrio ị jị, o ir pats grožis yra neišardoma objektyvumo ir subjektyvumo vienovè. Vertinimas visuomet yra pasirinkimo sprendimo aktas, kuris negalimas be subjekto (Jurkštas 1994).

Kraštovaizdžio architektūros tyrimus apibendrino ir atskiru metodiniu leidiniu - Urbanizuoto kraštovaizdžio analizès ir vertinimo metodika - išleido Klaipédos universiteto (KU) mokslininkų kolektyvas (Grecevičius et al. 2013). Tai bene išsamiausiai ịvairius architektūrinès aplinkos tyrimų metodinius pagrindus pristatantis leidinys lietuvių kalba. Lietuvos urbanistikos ir kraštovaizdžio architektūros projektavimo samprata ir mokslo darbai vis dažniau remiasi Jungtinès Karalystės architektų ir urbanistų mokymu ir patirtimi (Gražulevičiūtė-Vileniškè 2010, 2013; Urbonas 2013; Grecevičius et al. 2013; Kamičaitytė-Virbašienè ir Vitkuvienė 2015). Britų tradicijoje (Start with the park... 2005) išskiriamos aš- 
tuonios kokybinès projektuojamos viešosios erdvės charakteristikos: darnumas; charakteris ir išskirtinumas; aiškios ribos; ryšiai ir pasiekiamumas; skaitomumas (arba suvokiamumas); adaptyvumas (gebejjimas prisitaikyti); lankytojų įtraukties kriterijus; biologinès ịvairovès kriterijus. Šiais kriterijais vadovaujantis turètų būti analizuojama viešojo želdyno - parko, skvero, parkinio tako, miško parko ir pan. - kokybè, viešojo intereso tenkinimo laipsnis. Parkų tyrimo metodikos aspektai aptarti ir KU metodiniame leidinyje (Grecevičius et al. 2013). Aptariant metodiką daugiau akcentuojami dendrologiniai (dendrofloros rūšinès sudèties) tyrimai ir parkų būklès îvertinimas. Iliustracijose pateikiami parko funkcinių galimybių tyrimo ir veiklos modeliavimo organogramų pavyzdžiai. Planinès ir erdvinès struktūros tyrimai apibūdinami labai glaustai: parko planinė erdvinè struktūra vertinama vizualiniu būdu, atliekant tyrimus objektuose (želdyno apžiūrèjimas, fotofiksacija) ir kameralinius tyrimus - analizuojama aerofotografinè medžiaga, literatūros šaltiniai (Grecevičius et al. 2013). Apie kraštovaizdžio tyrimų kompleksiškumą išsamiai pasisako lietuvių mokslininkai, teigdami, kad kraštovaizdis yra daugelio mokslų ir profesijų interesų sritis. Kraštovaizdžio vertinimo ir suvokimo problemas sprendžia filosofija, sociologija, aplinkos psichologija, geografija, ekologija ir t. t. Kiekviena mokslo sritis kraštovaizdžio tyrimus praturtina savo požiūriu ir metodais (Zaleskiené et al. 2013).

Kraštovaizdžio architektūros tyrimams apibūdinti ir vykdyti tinka bendrieji visuotiniai tyrimo metodai: analizè, abstrahavimas, apibendrinimas, palyginimas, analogija, indukcija, dedukcija, modeliavimas, klasifikavimas. Pagal informacijos apdorojimo pobūdị ir principus visus tyrimo metodus galima skirti $\underset{i}{ }$ matematinius, statistinius, geografinius. Svarbiausias ir esminis geografinių tyrimų grupés metodas yra kartografinis metodas. Surinkti informaciją ir duomenis žemėlapiui galima ịvairiais būdais, todèl iš esmès kartografinis metodas aprépia kelis tyrimo būdus ar etapus, būtent: ekspedicinị (tyrimų vietose) ir kamerinị. Kraštovaizdžio architektūros objektų erdvinè struktūra gali būti sèkmingai tiriama, modeliuojama šiuolaikinių ir istorinių ikonografinių vaizdų analizès būdu. Diagonalinès (trimatès) arba tiesiosios (ortofoto) projekcijos vaizdai, skaitmeninès nuotraukos (fotofiksacija) teikia daug informacijos. Kraštovaizdžio vizualinès kokybès (poveikio) tyrimų technologijos, jungiančios savyje geografinius ir kitus vaizdų analizès metodus, žengia tvirtus žingsnius moksle ir praktikoje (Kamičaitytė-Virbašienè et al. 2015; Abromas 2015 ir kt.). Analogijos, vaizdų palyginimas, susiejimas su konkrečia topografija yra puikus kraštovaizdžio architektūrinès aplinkos tyrimo būdas ir integralumo pavyzdys.

Kraštovaizdžio estetinio poveikio ir jo vertinimo klausimus nagrinèjo ir visą eilę metodų bei kriterijų pasiūlè mokslininkai S. Kaplan $(1982,1989)$ A. Stamps III (2004); A. Ode, M. S. Tveit ir G. Fry (2008); A. Berleant (2010; 2016); D. J. Stobbelaar ir B. Pedroli (2011); A. Brink ir D. Bruns (2012); R. van Etteger, I. H. Thompson ir V. Vicenzotti (2016) ir kt.. Percepinès kraštovaizdžio 
analizės metodus išvystė S. Kaplan $(1982,1989)$ ir A. Stamps III (2004). Kaip teigia JAV mokslininkas James Palmer, geriausiai žinomus kraštovaizdžio suvokimo tyrimus atliko mokslininkai Kaplanai (1989) ir jų studentai, pasiūlydami aplinkos suvokimo modelį, susietą su žmogaus evoliucija. Jų manymu, žmonėms reikia žinoti ir suprasti supantị pasauli (Palmer 2003). Christof Alexander (1977) pasiūlytas daugiasluoksnis miesto pažinimo A pattern language metodas iš esmès yra labai artimas kraštovaizdžio architektūros principams.

K. Lynch $(1960 ; 1982 ; 1984)$ sukurti miesto suvokimo analizès metodai pritaikomi kraštovaizdžio architektūroje. Kaip teigia J. Dūdėnas, K. Lynch miesto vaizdinio teorija bei B. Hillier erdvès sintaksès praktika pirmiausia remiasi kognityvinèmis, o ne utilitariomis architektūros savybėmis. Architektūros formų ir funkcijų suprantamumas arba ,perskaitomumas“ taip pat yra savarankiška funkcija, be kurios architektūra nesuteikia galimybiu ja naudotis. Urbanistikoje analogiškai veikia gebejjimas išskirti konkrečios erdvès identitetą, kuris tampa svarbia navigacine, o paskui ir kultūrine bei ekonomine funkcija.

Kadangi urbanistiniai sprendiniai neišvengiamai susiję su nagrinejjamos teritorijos gamtiniu pagrindu ir kraštovaizdžio formavimu, akivaizdu, kad urbanistinei analizei ir sprendiniams gali būti naudingi kraštovaizdžio architektūros principai, metodai ir priemonès. Prioritetą miesto tvarkymo procese kraštovaizdžiui ir kraštovaizdžio architektūros principams skiria prancūzų mokslininkai C. Stefulesco (1993); A. Masboungi (2001); A. Romain (2010); M. Collot, (2011); P. Donadieu (2012); belgas L. Kroll (2012). Kraštovaizdžio architektūros vaidmuo tvariuose urbanistiniuose procesuose išsamiai nagrinètas prancūzų mokslininkų H. Soulier (2006); C. Abaut-de Chastene (2011); N. Bchir Jaber (2013); F. A. Leger-Smith (2014) daktaro disertacijose. Kraštovaizdžio architektūros metodų taikymą architektūroje savo disertacijoje Architecture with landscape methods nagrinejo D. Jauslin (2010).

Vadovaujantis kraštovaizdžio architektūros metodais sukuriamas procesas laike ir erdvejje, įsisavinami visi paviršiai, pasiūlomos veiklos ir darbo metodai bei sutelkiama vaizduote (Corner 2006). Kraštovaizdžio architektūroje komplesiškai taikomi šie pagrindiniai metodai - anamnezès, proceso, erdvinio sekvenavimo ir konteksto (Marot 1995). Kraštovaizdžio architektūros metodų esminis skirtumas nuo kitų tradicinių urbanistikoje taikomų metodų yra tas, kad jie integruoja gamtinius, socialinius bei kultūrinius aplinkos procesus ir identifikuoja naudingas jų sinergijas. Kiekvienas iš išvardintų kraštovaizdžio architektūros metodų yra kompleksinio pobūdžio ir savyje telkia kitus svarbius analizės ir tyrimo metodus.

Mokslinio tyrimo struktūroje informacija interpretuojama kaip tam tikra visuma vienareikšmiškai suvokiama kalba išreikštų signalų, kurie yra mokslinès analizės objektas. Vaizdų informacija gali būti fiksuojama brěžinių (planų), piešinių (eskizų) ar fotonuotraukų pavidalu. XX a. pabaigoje labai paplito duomenų 
rinkimas distanciniais (nuotoliniais) metodais. Tai ir kosminès, ir aeronuotraukos, ortofoto žemėlapiai; vandenyje, ore, grunte ịrengtų daviklių duomenų gavimas ir perdavimas ryšio priemonèmis. Geografinių informacinių sistemų (GIS) technologijų taikymas randa kelią ir kraštovaizdžio architektūroje. JAV miestų modeliavimo ir virtualia realybe grindžiamos aplikacijos sėkmingai taikomos tiek projektavimo, tiek architektūrinès aplinkos tyrimuose. Naudojant geografines informacijos sistemas techniškai tampa įmanoma didelių duomenų kiekių, surinktų iš skirtingų šaltinių, integracija. Tai daro jas ypač tinkamas naudoti teritorijų planavimui ir valdymui. GIS taip pat leidžia planuotojams operuoti turima informacija visais būdais (Zagorskas 2007). Kamerinių tyrimų grupei priskirtini topografiniai ir kartografiniai tyrimai (GIS), ikonografiniai tyrimai, istoriniai tyrimai, dokumentinių fotografijų analizè, sociologiniai tyrimai. Lauko ekspediciniai tyrimai apréptų archeologinius tyrimus, architektūrinius tyrimus, vandenų (hidrografinius, hidrologinius ir hidrotechninius) tyrimus, grunto ir inžinerinès geologijos (hidrogeologijos) tyrimus, dendrologinius, botaninius, dirvožemio ir kitus fizinius ir gamtamokslius tyrimus. Empiriniai metodai (stebejjimas, aprašymas, matavimai, eksperimentas) ir teoriniai metodai (formalizavimas matematiniais modeliais, aksiomizavimas, hipotetinè dedukcija), sèkmingai taikomi ịvairiose mokslo šakose, gali būti taikomi ir kraštovaizdžio architektūros tyrimuose.

Morfologinès analizès metodas yra dažnai praktikuojamas tiek kraštovaizdžio, tiek urbanistiniuose tyrimuose. Kraštovaizdžio morfologiniais vienetais dažniausiai vadinami pagal abiogeninių, biogeninių ir sociogeninių komponentų bei jų kompleksų erdvinio pobūdžio bendrumą išskirti tipologiniai kraštovaizdžio arealai. Šioje srityje nemažai darbavosi P. Kavaliauskas ir kiti geografijos mokslininkai. Miesto morfologines struktūras išsamiai nagrinèjo I. Alistratovaitè-Kurtinaitienè, D. Dijokienè (2013). Kaip teigia prancūzų urbanistas R. Allain, miesto morfologija yra fizinès miesto formos, jo palaipsniui augančio struktūros audinio ir jo atskirų elementų, apibrěžiančių tam tikrus derinius, santykių ir kombinacijų tyrimas. Ši sudetinga realybè analizuojama įvairiais masteliais ir požiūriais, peržengia vienos disciplinos sriț. Savo teoriniais aspektais miesto morfologinis tyrimas susijęs su miesto geografija, istorija ir architektūra. Morfologinis tyrimas yra pagrindas suprasti miestų kraštovaizdį. Nors kraštovaizdžio ir urbanistinès morfologijos metodai skiriasi, tačiau daug tyrëjų ar praktikų nebeatskiria šiu dviejų sričių, kurių sąveika ir vienas kito papildymas yra akivaizdūs (Allain 2004). KTU darbuose vis plačiau taikomi fraktalinès analizès metodai. Urbanistinés struktūros ar jų dalys, kaip ir fraktalas, kad ir kiek tankètų, negali visiškai užpildyti jam skirtos erdvès (porètumo požymis) - mieste lieka tam tikrų gamtinio pobūdžio teritorijų, tarp pastatų - erdvių ir pan. Dèl minètų analogiškų esminių savybių miesto struktūra yra vis dažniau modeliuojama kaip fraktalas (Batty 1994; Salingaros 2005; Zaleckis 2011). Tai perspektyvi 
miestovaizdžio formavimo vertinimo metodika, padedanti atskleisti ir apibendrinti želdyno ar kitos viešosios erdvès, kaip nuolat besikeičiančios sistemos, atsinaujinimo ir evoliucionavimo potencialą, ịvertinti jo posistemių - substruktūrų gyvybingumą ir tikslingumą (Kamičaitytė-Virbašienè ir Vitkuvienė 2015).

Kraštovaizdžio tyrimuose nuo seno yra naudojamas gardelès metodas, siekiant nagrinejjamą teritoriją padengti vienodo dydžio ir formos ploto vienetais. Tokio pobūdžio tinklas leidžia orientuotis atstumuose, lengvai suvokti tam tikrų struktūrinių elementų užimamus plotus konkrečioje gardelèje ir juos palyginti. Pavyzdžiui Australijos mokslininkai Mendel ir Kirkpatrick (1999) $10 \times 10 \mathrm{~km}$ gardelès principą naudojo Tasmanijos (Australija) vaizdingo reljefo, vandens telkinių formų, augalijos įvairovès, vandens krioklių bei urvų ir kitų gamtinių išteklių estetiniam vertinimui ir reprezentavimui. Gardelès metodas leido gamtos išteklių kiekybinius pokyčius vertinti laiko distancijoje, analizuojant padèti 1937, 1970 ir 1992 metais (Mendel 1999; Ward 2009; Mirkarimi 2017). Šiuolaikinių technologijų eroje gardelès metodas tapo sudètine įvairių informacinių sistemų dalimi. Kaip teigia G. Vaitkus ${ }^{6}$, vienas iš kertinių Europos erdvinių duomenų infrastruktūros komponentų yra vieningos europinès statistinių informacinių gardelių sistemos sukūrimas naudojant vieningą projekcinę koordinačių sistemą (Vaitkus 2006). Gardelès dydžio pasirinkimas priklauso nuo konkretaus uždavinio, t. y. nuo atliekamo tyrimo mastelio (Vaitkus 2006). Geografijos mokslininkų ${ }^{7}$ teigimu, $1 \times 1 \mathrm{~km}$ dydžio etaloninès gardelès metodas yra taikomas Europos kraštovaizdžio monitoringo sistemose ir Lietuvai specialistai rekomenduoja pereiti prie vieningos kraštovaizdžio monitoringo sistemos (Veteikis et al. 2015). Gardelès principu grịstos CORINE žemès dangos monitoringo ir tyrimų informacinès sistemos yra rekomenduojamos naudoti teritorijų planavime. Ši koncepcija ypač propaguojama Didžiojoje Britanijoje ir Airijoje, kur, projektuojant naujas urbanizuotas teritorijas, praktiškai visada atliekami specifiniai kraštovaizdžio vertinimo tyrimai ir net kuriami sudètingi kompiuteriniai erdviniai kraštovaizdžio modeliai, kurie leidžia optimaliai suprojektuoti gyvenamuosius kvartalus, komunikacijas ir želdinių plotus taip, kad būtų užtikrinta maksimali žmonių gyvenimo kokybė (Vaitkus 2006).

Daugiakriterinès analizès metodas yra svarbus nustatant kriterijų reikšmes ir reikšmingumus, lyginant variantų prioritetus, naudingumo laipsnị ir pan. Kokybinių kriterijų reikšmès dažniausiai nustatomos remiantis ekspertiniais metodais (Zavadskas et al. 1998). Vienas iš daugiakriterinès analizès metodų Analitinès hierarchijos proceso - AHP (angl. analytic hierarchy process) metodas, sukurtas

\footnotetext{
${ }^{6}$ Lietuvos CORINE žemės dangos GIS duomenų bazès taikomojo panaudojimo aplinkosaugos srityje studija (2006).

${ }^{7}$ Kraštovaizdžio struktūros pokyčių probleminiuose arealuose vertinimo vietiniu lygmeniu ataskaita (2015).
} 
1980 m. Pitsburgo universiteto profesoriaus Thomas L. Saaty (1926-2017). AHP jau buvo pritaikyta daugybėje sričiu, kaip pramonės kontrolè, inžinerija, ekonomika, medicina, kalnakasyba ir pan. Šis metodas taip pat populiarus ir sèkmingai naudojamas planavime, aplinkosaugoje, sprendžiant klimato kaitos problemas ir kitus klausimus, kai reikia apsispręsti dẻl daugelio kriterijų prioritetų (Saaty 1980; Lifang 2008; Desai, Bhaghat 2017). Naujausiuose mokslininkų straipsniuose pastebima, kad daugiakriterinès analizès metodas palyginus mažai taikomas architektūroje. Čia pat pripažistama, kad daugiakriterinès analizès metodai (MCDM), nors ir negausiai taikyti tvarumo problemoms inžinerijoje ir kitose srityse tirti, parodè, kad jie yra labai tinkami vertinant kriteriju grupes ir derinant su kitais tvarumo tyrimo metodais (Mahdiraji et al. 2018).

Sociologinio aspekto reikšmès suvokimas ir integravimas projektuojant bei kuriant aplinką gali būti traktuojamas ir kaip gilias istorines šaknis turintis, ir kaip gana naujas reiškinys. JAV urbaniste Jane Jacobs gana anksti (1961) suvokè ir nagrinejo miesto sociologinius aspektus, formulavo miesto sociologinị modelį (Jacobs 1992). Lietuvoje tai buvo architektūros mokslininkai J. Vanagas (1996), V. Jurkštas (1994). Urbanizuoto kraštovaizdžio analizės ir vertinimo metodologai (Grecevičius et al. 2014; Gražulevičiūtè-Vileniškè 2014) pritaria, kad sociologiniai tyrimai - stebejimas ir interpretacija, nestruktūruotos ir struktūruotos apklausos, interviu, atvejo analizè, grupès diskusija - gali būti taikomi urbanizuotų teritorijų, miesto teritorijų funkcionavimo ir naudojimo tyrimams. Miesto aplinkos tyrimams gali būti taikomi įvairūs informacijos rinkimo būdai.

Apklausa yra populiariausias pirminès sociologinès informacijos rinkimo metodas. Anketinè apklausa - tai susistemintas informacijos iš respondentų rinkimas pateikus anketą. Interviu naudojamas tyrimo informacijai rinkti klausejui tiesiogiai ir kryptingai bendraujant su respondentu. Tiek anketinè apklausa, tiek interviu gali būti labai struktūruoti, kai pateikiami galimi atsakymo variantai, ir mažai struktūruoti, kai pateikiami atvirieji klausimai ar numatomos tik pagrindinès pokalbio temos. Diskusija, pokalbis grupeje taip pat gali būti traktuojami kaip interviu atmainos (Gražulevičiūtè-Vileniškè 2014).

Siekiant konsensuso tarp ekspertų nuomonių tam tikrais klausimais yra taikomas ekspertu apklausos Delphi metodas (angl. Delphi method), kurio principas - kartotinè skirtingų sričių ekspertų grupių apklausa tyrimui rūpimais klausimais, prieš tai juos supažindinant su ankstesnès apklausos rezultatais. Šis metodas sėkmingai yra taikomas ir kraštovaizdžio architektūros srityje ir yra plačiau pristatytas moksliniame kraštovaizdžio architektūros tyrimų metodikos leidinyje Research in landscape architecture: methods and methodology (Brink et al. 2017).

Daugelio urbanistinės aplinkos tyrimų, susijusių su verčių nustatymu, pagrindas yra kriterijai. Kaip teigia Justinas Dūdènas, žmogaus siekiamos vertès jungiasi $\mathfrak{i}$ verčiu grandines arba grupes, kurios toliau gali būti skaidomos pagal 
konkrečias programas. Šios stambiujų tikslų grupès skirtingais būdais nustatinèjamos bent keliomis sociologinėmis metodikomis. Viena žinomiausių - Abraham Maslow (1943) žmogaus poreikių piramidè. A. Maslow (1908-1970) pasiūle žmogaus poreikių grupavimą ir šių grupių hierarchiją, pagal kurią žmogus pirma stengiasi patenkinti savo fiziologinius ir saugumo poreikius, tik tuomet rūpinasi bendravimu, pagarba ir savęs realizavimu. Ši poreikių hierarchija nesunkiai pritaikoma architektūros programoms ir jos vertèms klasifikuoti. (Dūdènas 2015). Pavyzdžiui, JAV mokslininkai diskusijai pateikia architektūros ir dizaino sisteminimo, orientuoto ị A. Maslow žmogaus poreikių hierarchiją, tyrimo rezultatus. Jų teigimu, naudojant A. Maslow poreikių hierarchiją kaip paradigmą, jie savo tyrimais siūlo struktūrinị aiškios sistemos (angl. elegant system) apibrežimą, kuris grindžiamas esamais ir galimais žmonių poreikiais, o ne atsitiktinėmis savybėmis (Salado 2013). JAV mokslininkas James Palmer teigia, kad A. Maslow poreikių hierarchija sustiprina kraštovaizdžio suvokimo tyrimų svarbą. Tyrimai rodo, kad, prie pagrindinių poreikių kraštovaizdžiui žmonės priskiria savo sveikatos klausimus. Socialiniu lygmeniu poreikiai susiję su kraštovaizdžio dėka besiformuojančiais žmoniu santykiais. Aukščiausi hierarchijos lygiai susiję su savirealizacija ir transcendentiniu impulsu, kuris kraštovaizdžio prasme gali būti siejamas su ekologine arba Gajos estetika (Palmer 2003). Didèjantis dèmesys architektūros kokybei reikštų tam tikrą visuomenès ,palypèjimą“ A. Maslow piramidès laipteliais (Bakšienè 2015).

\subsection{Pirmojo skyriaus išvados ir disertacijos uždavinių formulavimas}

1. Darbe atskleista kraštovaizdžio architektūros sampratos raida ir veiklos apžvalga suteikia naujos informacijos apie profesijos vardo kilmę, fiksuojama nauja jo vartojimo pradžios data. Šiuo metu Lietuvoje oficialiai vartojamas kraštovaizdžio architektūros apibrèžimas, ịtvirtintas Lietuvos Respublikos kraštovaizdžio politikos apraše ir atitinkantis tarptautinę termino „kraštovaizdžio architektūra" (angl. landscape architecture) sampratą, yra priimtinas ir vartotinas moksle bei praktikoje. Šis apibrèžimas yra lakoniškas ir talpus, pakankamai gerai ir glaustai atspindintis kraštovaizdžio architektūros misiją miesto planavime ir projektavime. Atsižvelgiant ị tai, kad kraštovaizdžio architektūra yra auganti ir savo kompetencijas plečianti profesija, aktualiau yra aptarinèti ne pati pavadinimą, o būtent su šia profesija susijusių veiklų ir kompetencijų klausimus.

2. Mokslinė literatūros analizė atskleide, kad kraštovaizdžio architekto profesija, kito nuo miesto pagražinimo funkcijų iki strateginių bei miesto planavimo klausimų sprendimo, tapo urbanistinio projektavimo dalyve ir, daugeliu atveju, vieningų kompleksinių sprendimų iniciatore. Mokslinès literatūros analizė ir 
praktiniai miestų vystymo pavyzdžiai rodo, kad kraštovaizdžio architektūra yra išskirtinè disciplina, kuri generuoja projektuotojų kompetencijas, leidžiančias imtis uždavinių racionaliai ir kūrybiškai sujungti gamtinius ir urbanistinius procesus tiek miesto strategijų kūrimo, tiek planavimo ir projektavimo stadijose. Todèl yra tikètina, kad taikant kraštovaizdžio architektūros principus, metodus ir priemones tvarkant miestą pasiekiama racionalių gamtinių ir urbanistinių struktūrų sąveikos rezultatų.

3. Kraštovaizdžio architektūros profesinès raidos analizès rezultatai patvirtino hipotezę, kad kraštovaizdžio architektūra yra neatskiriama miesto vystymo ir urbanistinio projektavimo proceso dalis, o jai priskiriamų uždavinių pobūdis ir apimtys priklauso nuo tvarkomos teritorijos planavimo ir projektavimo lygmens, prioritetų ir programos. Kraštovaizdžio architektūros profesinès veiklos lauko uždaviniai vystėsi kartu su urbanistinių idèjų kaita. Sisteminiai miesto žaliujų struktūrų pagrindai buvo padèti dar XIX a. pabaigoje - XX a. pradžioje. Dabar daugelyje šalių ,žaliasis tinklas" (angl. green network; pranc. trame verte) arba želdynų sistema pirmiausia suprantama kaip miestų plètotès struktūrinè priemonè. Miesto atžvilgiu želdynų sistema tarnauja socialiniams tikslams: suteikia kokybišką kasdieninị kraštovaizdị ir visame mieste tolygiai išdėstytas, gyventojams tarnaujančias gamtines rekreacines erdves.

4. XX a. pabaigoje atsiranda naujos urbanistinès kryptys, miesto planavimo ir projektavimo procesuose pirmenybę teikiančios ekologijos ir kraštovaizdžio klausimams. Viena iš jų - kraštovaizdžio urbanistika (angl. landscape urbanism) - yra urbanistine ideologija, kuria vadovaujantis miestas gali būti ịsivaizduojamas ir projektuotas kaip vientisas kraštovaizdis. Gamtinès ir urbanistinès struktūros sudaro vientisą miesto audinį, o jų sąveika priklauso nuo urbanistinio proceso dalyvių - privataus asmens, visuomenès, valdžios institucijų, verslo imonių bei profesionalų projektuotojų etinių nuostatų, jų savitarpio supratimo ir bendradarbiavimo. Šiuolaikinio pasaulio iššūkių fone gamtinių ir urbanistinių struktūrų sąveika yra sąlygojama tvaraus miesto koncepcijos, kuri pasiekiama vadovaujantis ekologine etika. XXI a. vis labiau ịsigali socialinès dimensijos akcentavimas architektūrinès aplinkos formavimo ir pertvarkymo, ypač urbanistikos, tuo pačiu ir kraštovaizdžio architektūros, srityje.

5. Mokslinių tyrimų analizė parodè, kad kraštovaizdžio architektūros ir urbanistikos sričių tyrimų laukas Lietuvoje ir užsienyje gerokai skiriasi. Užsienio mokslininkai tirdami šiuos abu fenomenus juos labiau susieja. Kraštovaizdžio architektūra nagrinejama kaip neatskiriama urbanistinių tyrimų dalis arba miestas analizuojamas kaip kraštovaizdis. Lietuvoje panašios tematikos moksliniai tyrimai pasiskirsto tarp kraštovaizdžio tyrimų ir urbanistinių tyrimų. Lietuvos urbanistiniams tyrimams yra būdinga tai, kad net nagrinejjant atviras miesto erdves, praktiškai neužsimenama apie kraštovaizdžio architektūros fenomeną ir uždavinius. 
6. Mokslinès literatūros analizè atskleidè, kad kraštovaizdžio architektūros ir urbanistikos sprendinių sąveikos problematikai nagrinèti efektyviausi yra kompleksiniai metodai. Kraštovaizdžio tyrimuose gali būti naudojamas gardelès metodas, siekiant nagrinejjamą teritoriją padengti vienodo dydžio ir formos ploto vienetais. Daugiakriterinès analizès metodas yra tinkamas vertinant kriterijų grupes, nustatant kriterijų vertes ir reikšmingumus, lyginant variantų prioritetus, naudingumo laipsnį. Ekspertų apklausa, taikant Delphi metodą, suteikia galimybę išgryninti atitinkamuose procesuose dalyvaujančiujų specialistų nuomones mokslo tyrimams aktualiais klausimais. A. Maslow (1943) žmogaus poreikių hierarchijos piramidè yra veiksmingas analizès metodas tiriant kraštovaizdžio architektūros ir urbanistikos sprendinių sąveiką visuomenès poreikių tenkinimo aspektu.

7. Kadangi urbanistiniai sprendiniai neišvengiamai susiję su nagrinèjamos teritorijos gamtiniu pagrindu ir kraštovaizdžio formavimu, akivaizdu, kad urbanistinei analizei ir sprendiniams yra naudingi kraštovaizdžio architektūros principai, metodai ir priemonès. Kraštovaizdžio architektūros metodų esminis skirtumas nuo tradiciškai taikomų urbanistinių yra tas, kad jie integruoja gamtinius, socialinius bei kultūrinius aplinkos procesus. Praktiškai bet kuri planuojama ar projektuojama teritorija, kuriai pradedami taikyti kraštovaizdžio architektūros principai, metodai ir priemonès, tampa kraštovaizdžio architektūros objektu. 



\section{2}

\section{Kraštovaizdžio architektūros ir urbanistikos sąveikos tyrimo metmenys}

Atliktų teorinių tyrimų rezultatų analizė ir pagrindinis darbo tikslas suponuoja tolimesnius kraštovaizdžio architektūros ir urbanistikos sąveikos tyrimo aspektus: (1) miesto planavimo lygmuo, kuriame dedami šios sąveikos „pamatai“; (2) miesto kūrimo procesuose dalyvaujančių specialistų mintys apie sąveikos galimybes; (3) tyrimas kvartalo lygmenyje, kuriame geriausiai matomas minètos sąveikos potencialas. Šiame skyriuje yra pristatomi trys tyrimai, kurių rezultatų pagrindu kuriamas kraštovaizdžio architektūros ir urbanistikos sprendinių sąveikos optimizavimo metodinis modelis. Pirmuoju tyrimu nagrinejjama kraštovaizdžio architektūros ir urbanistikos sprendinių potenciali sąveika miesto planavimo lygmeniu. Siekiama Lietuvos mastu atskleisti kraštovaizdžio architektūros kūrybinio lauko potencialą, programuojamą bendrujų planų sprendiniuose. Antruoju tyrimu siekiama sužinoti kraštovaizdžio architektūros ir urbanistikos ekspertų nuomones dèl šių profesinių laukų sąveikos ypatumų. Tyrime taikytas sociologinis ekspertų apklausos Delphi metodas. Šis tyrimas atskleidžia abiejų profesinių veiklų kūrybinių laukų sąsajas ir bendrumą, o tuo pačiu ir sprendinių sąveikos optimizavimo poreikį. Trečiasis tyrimas atliekamas taikant teorinio kraštovaizdžio architektūros ir urbanistikos sąveikos raidos analizės, bendrujų planų tyrimo ir ekspertų apklausos rezultatų pagrindu sudarytą optimalios sąvei- 
kos tyrimo kriterijų sistemą. Tiriama gamtinių ir urbanistinių struktūrų sąveika, pastarają traktuojant kaip svarbų miesto raiškos bei kraštovaizdžio architektūros kūrybinio lauko ir sąveikos su urbanistiniais sprendiniais potencialą. Šio skyriaus medžiaga paskelbta dviejose autorès publikacijose recenzuojamuose mokslo žurnaluose (Deveikienè 2016; 2018).

\subsection{Kraštovaizdžio architektūros ir urbanistikos sprendinių sąveika teritorijų planavime}

Kaip minėta pirmojo skyriaus išvadoje, kraštovaizdžio architektūros profesinès raidos ir raiškos urbanistiniuose procesuose analizès rezultatai patvirtino hipotezę, kad kraštovaizdžio architektūra yra neatskiriama miesto vystymo ir urbanistinio projektavimo proceso dalis, o jai priskiriamų uždavinių pobūdis ir apimtys priklauso nuo tvarkomos teritorijos planavimo ir projektavimo lygmens, prioritetų ir programos. Esminiams sisteminiams miesto žaliụų struktūrų klausimams pagrindai buvo padèti dar XIX a. pabaigoje - XX a. pradžioje. Želdynų sistemos idèja XX a. viduryje persikèlè ị urbanistikos lauką. Tiek žaliosios infrastruktūros, tiek naujosios urbanistikos postulatuose labai aiškiai iškeliami pasiekiamumo, judejjimo pésčiomis ir dviračiais tinklo, daugiafunkciškumo, efektyvaus išteklių naudojimo, darnumo ir gyvenimo kokybès kriterijai. Siekiant užtikrinti šių kriterijų ịgyvendinimo veiksmingumą daugelis klausimų turètų būti sprendžiami bendrojo plano lygmeniu. Šio tyrimo rezultatai paskelbti autorès publikacijoje „Kraštovaizdžio architektūros objekto ir urbanistinio konteksto sąveikos problema igyvendinant miestų bendrųjų planų sprendinius“" (Deveikienė 2016).

\subsubsection{Miestụ bendrujụ planų sprendiniai gamtinio karkaso ir želdynų sistemos vystymo aspektu}

Miesto gamtinio karkaso sistemoje ekologiniu aspektu svarbu ne tiek teritorijos (žemės sklypų) paskirties ir nuosavybės dalykai, bet tos teritorijos tvarkymo pobūdis, projektuojant ir išsaugant jos savybes, lemiančias ekologinio kompensavimo pajègumą. Ekologiniai tinklai ir gamtinis karkasas yra skirti ekosistemoms ir biologinei ịvairovei palaikyti. Formuojant želdynų sistemas yra svarbiau jų tinkamumas rekreacijai, kultūros poreikiai, žmogaus aplinkos higieninè kokybė. Ekologiniai tinklai ar gamtinis (ekologinis) karkasas gali sutapti su želdynų sistemos komponentais, nors šiaip dauguma želdynų nėra vien gamtinės teritorijos. Kaip pabrěžè dr. G. Daniulaitis (1999), miesto gamtinio karkaso planavimas skiriasi nuo užmiesčio gamtinio karkaso planavimo ne tik jo elementų fiziniais dydžiais, bet ir karkasui priskiriamomis funkcijomis ir jų prioritetais. Išskirtini trys gamtinio karkaso modelių (projektavimo principu aprašų) tipai: 1) ekologinis kompensacinis; 2) socialinis funkcinis; 3) architektūrinis kompozicinis. Integ- 
ruotas minètų trijų modelių taikymas yra visų požiūrių ì gamtinių sąlygų ir želdynų reikšmę mieste sintezė planuojant, statant ir tvarkant miestą. Miesto gamtinis karkasas yra neatskirtinai susijęs su urbanistiniu karkasu ir jo plètojimu. Jis yra ir loginis modelis, suteikiantis hierarchizuotą struktūrą bei funkcijas miesto gamtinèms teritorijoms, ir projektuojamas darinys, kartu su kitais miesto elementais formuojantis bendrają miesto planinę ir erdvinę tūrinę miesto struktūrą su želdynu sistema (Daniulaitis 1999). Siekiant integralumo miesto teritorijas siūloma nagrinèti aprėpiant gamtinių ir urbanistinių struktūrų sandus, kurių sąveika analizuojama atsižvelgiant pagal išskirtus tris gamtinio karkaso prioritetus.

Ekologinio kompensavimo prioritetas - nustatoma šių teritorijų ir jungčių sistemos paskirtis, kuri yra užtikrinti gyvosios ir negyvosios gamtos komponentų migraciją bei išskaidyti antropogenini poveikị didesnèje, jị kompensuoti galinčioje teritorijoje. Mieste šias funkcijas sunkiau igyvendinti, nes efektyvumas pasiekiamas didelèse teritorijose, todèl labai svarbu išsaugoti vientisas vertingiausias ekologinio tinklo - želdynų ir miškų, natūralių pievų - teritorijas. Svarbiausia jų funkcija yra ekologinis stabilumas. Tokio pobūdžio žaliesiems plotams ir jungtims nebūtinas didelis tinkamumas rekreacijai. Jie planuojami tokios formos ir lokalizuojami taip, kad ekologiniai reikalavimai būtų kuo geriau ịvykdomi. Pagal BP tai atitinka numatytas ekstensyvaus želdynų naudojimo teritorijas. Rekreacinis žaliosios struktūros prioritetu siekiama sudaryti sąlygas miesto gyventojams aktyviai ir kokybiškai ilsètis, atkurti fizines ir dvasines jëgas, laisvai judèti žaliosiomis teritorijomis tarp rekreacijos zonų ir gyvenamujų vietų, kitų žmonių srautus akumuliuojančių vietų. Žaliosios jungtys turètų skatinti naudotis ekologiškesnèmis transporto priemonèmis - dviračiais. Šio tipo teritorijų ịrengimas ir lokalizacija gali labai ịvairuoti, nes rekreacinius poreikius galima užtikrinti ịvairiais būdais: teritorija gali būti net labai artima gamtinei arba natūralių gamtinių elementų gali būti labai nedaug. Architektūrinis kompozicinis prioriteto teritorijoms ir jungtims keliami estetiniai reikalavimai. Svarbiausia jų funkcija yra miesto ịvaizdžio formavimas. Šio tipo teritorijos planuojamos siekiant pagerinti miesto vaizdą, suskaidyti žalumos intarpais urbanizuotus masyvus, padidinti teritorijų išraiškingumą, pagerinti miesto apžvelgiamumo sąlygas, formuoti miesto siluetą ir panoramas. Ypač aktualios šiuo požiūriu yra gamtinès jungtys upių pakrantėmis, viršutine šlaitu briauna. Kalvoto reljefo sąlygomis ypatingą svarbą igyja kalvų viršus.

Bendrasis miesto teritorijos planas yra kompleksinis miesto plètros krypčių (planuojamos raidos) ir prioritetų dokumentas, numatantis miesto raidos ir tvarkybos principus ir sprendinius ne trumpesniu nei 10-15 metų laikotarpiu. Urbanistinis (technogeninis) ir gamtinis (žaliosios infrastruktūros) prioritetai bendrajame plane (toliau - BP) turi būti subalansuoti. Kaip teigiama Europos Komisijos informaciniame leidinyje, praktiškai vienas veiksmingiausių žaliosios infrastruktūros kūrimo būdų yra labiau integruota žemètvarka (arba, kitaip ta- 
riant, konsoliduotų sklypų perplanavimas), kurią geriausia pasiekti strateginiame bei teritorijų planavimo lygmenyje, t. y. ištiriant ịvairios paskirties žemès erdvines sąveikas didelèje geografinèje teritorijoje (pvz., regione arba savivaldybejje). Be to, strateginis planavimas priverčia bendradarbiauti ịvairius sektorius ir kartu skaidriai bei kompleksiškai spręsti prioritetinio žemès panaudojimo klausimus vietos lygmeniu. Taikant teritorijų erdvini planavimą, infrastruktūra gali būti nukreipiama nuo jautrių vietovių, taip sumažinant tolesnès gamtinių buveinių fragmentacijos pavojų. Nustatomi būdai, kaip erdviškai vèl sujungti likusius natūralius gamtos plotus, pavyzdžiui, remiant buveinių atkūrimo projektus strategiškai svarbiose vietose arba integruojant ekologinių jungčiu elementus, pavyzdžiui, natūralias jungtis, ị naujas plètros sistemas (Europos Komisija 2010).

Bendruosiuose planuose numatytų žaliujų erdvių sąveika su kitomis planuojamomis teritorijomis detalizuojant ir igyvendinant sprendinius yra labai sąlyginè. Sąveikos problema ypač išryškejja pereinant i žemesnius planavimo ar projektavimo lygmenis, kada planavimo procese dalyvauja konkrečių žemės sklypų savininkai, tenka derinti visuomeninius, privačius interesus ir rasti racionalius sprendimus. Kaip buvo pastebèta Vilniaus miesto bendrojo plano monitoringo ataskaitoje, nemažèja BP keitimų pasiūlymų dèl statybų neužstatomose (tarp jų ir želdynų) teritorijose ir nèra teisinio mechanizmo suformuoti ir ịrengti vietinius želdynus naujos plètros teritorijose privačioje žemejje (Vilniaus miesto savivaldybės... 2015). Kai kurie autoriai teigia, kad miesto gamtiniam karkasui pagal jo sampratą, ịtvirtintą LR teisès aktuose, trūksta diskretiškumo - gamtinio karkaso teritorijų ribų aiškumo ir pagrịstumo bei sistemai būdingų jungčių. Ilgą laiką žaliosios jungties samprata urbanistikos teorijoje bei planavimo praktikoje, kartu gamtinio karkaso sampratoje nebuvo apibrèžta (Daniulaitis, Dimindavičiūtè 1999).

\subsubsection{Bendrieji planai - kraštovaizdžio architektūros ir urbanistikos sprendinių sąveikos optimizavimo priemonè}

Atsižvelgiant $\mathfrak{i}$ integralaus planavimo poreikius, tiriama, kaip Lietuvos miestų bendrojo planavimo dokumentuose atspindima žaliosios infrastruktūros ${ }^{8}$ sąveika su kitais urbanistiniais sprendiniais. Kadangi gamtinio karkaso lokalizavimo, želdynų sistemos kūrimo ir kraštovaizdžio formavimo darbai išskirtinai sudaro kraštovaizdžio architektūros veiklos lauką, šiuo tyrimu siekiama išsiaiškinti,

\footnotetext{
8 Žalioji infrastruktūra - sąlyginis pavadinimas, apimantis gamtinio karkaso, miškų ir želdynų sistemas. Europos komisijos komunikate taikoma tokia apibrèžtis : žalioji infrastruktūra - strategiškai suplanuotas gamtinių ir pusiau gamtinių zonų tinklas, kuriame kiti aplinkos objektai suprojektuoti ir tvarkomi siekiant sudaryti sąlygas įvairioms ekosistemų funkcijoms (Europos... 2013).
} 
kiek potencialios kraštovaizdžio architektūros ir urbanistikos sprendinių sąveikos ,programuoja“ bendrieji planai.

Tyrimui pasirinkti šie teritorinio planavimo dokumentai: Vilniaus miesto savivaldybės teritorijos bendrasis planas (rengejjas SI „Vilniaus planas, 2018); Kauno miesto savivaldybės teritorijos bendrasis planas (rengejai SI „Kauno planas“; UAB „Lyderio grupé“; UAB „Urbanistika“, 2013), Klaipėdos miesto bendrojo plano keitimas. Esama būklè (rengejjai UAB „Urbanistika“, UAB „Sweco“, 2016), Šiaulių miesto bendrasis planas (rengejjas UAB „Urbanistika, 2008), Utenos miesto teritorijos bendrasis planas (rengejas UAB „Urbanistika, 2008); Biržų miesto bendrasis planas (rengèjas UAB „Urbanistika, 2014).Tyrimui pasirinkti miestai, atsižvelgiant i skirtingas jų vystymo problemas, įdirbį, nagrinejjant želdynų ir viešųjų erdvių klausimus. Vilniaus miestas (plotas $401 \mathrm{kv}$. km; 536692 gyv.) pasirinktas dèl probleminių klausimų koncentracijos ir uždavinių sudètingumo.

Šio mokslinio darbo sudètyje bendrujų planų analizè buvo pradèta $2016 \mathrm{~m}$., tačiau $2018 \mathrm{~m}$. Vilniaus miestui pasirengus naujus bendrojo plano sprendinius, bendrujų planų tyrimas buvo atnaujintas, analizuojant tiek galiojančius Vilniaus BP sprendinius, tiek naujus siūlymus. Kaunas (plotas 157 kv. km; 288466 gyv.) ir Klaipėda (plotas 98 kv. km; 149015 gyv.) pasirinkti kaip antras ir trečias pagal dydị miestai, kurie tyrimui yra ịdomūs dèl labai skirtingos geografinès padèties ir urbanistinès raidos ypatumų. Klaipèdos miesto atveju nagrinejjama naujausia bendrojo plano keitimo medžiaga, nes ji atspindi dabartines aktualijas. Šiauliai pasirinkti kaip ketvirtas pagal dydi Lietuvos miestas (plotas 81 kv. m.; 100618 gyv.), turintis vidinio augimo potencialo. Utena - vidutinio dydžio miestas (plotas 15,32 kv. km; 34500 gyv. ) tyrimui ịdomus tuo, kad jame vykdoma nuosekli želdynų planavimo ir projektavimo bei igyvendinimo politika. Biržai (plotas 16,35 kv. km; 14999 gyv.) pasirinkti kaip nedidelis miestas, kuriame sąlyginai neseniai (2014-2015 m.) vykdyti želdynų ir kitų viešųjų erdvių tvarkymo, socializacijos ir urbanistinès integracijos tyrimai, kurių metu buvo išgrynintos miesto žaliujų viešųjų erdvių sąveikos su urbanistiniu konteksto problemos ir siūlyti naujos sinergijos sprendiniai.

Tyrimo metu nagrinejjami pasirinktų miestų bendrujų planų aiškinamieji raštai. Siekiama nustatyti, ar tekstinèje bendrojo plano dalyje yra numatytos žaliosios infrastruktūros ir kraštovaizdžio formavimo klausimų įvairiapusès sąsajos su kitomis miesto gyvenimą lemiančiomis strateginèmis temomis. Tyrimo metu kreipiamas dèmesys, ar bendrojo plano teiginiais siekiama užtikrinti žaliosios infrastruktūros veiksmingumą, sistemiškumą, pasiekiamumą ir nepertraukiamumą. Tyrimo rezultatai turi atsakyti į klausimus: (1) ar žaliosios infrastruktūros kūrimo ir kraštovaizdžio formavimo klausimai patenka ị miesto strateginius tikslus, uždavinius, vizijas; (2) ar atskiros bendrojo plano temos susietos su žaliosios infrastruktūros ir kraštovaizdžio formavimo klausimais; (3) ar tam tikrų proble- 
mų sprendimui yra rekomenduojami kraštovaizdžio architektūros metodai, principai ir priemonès; (4) ar pateikiamos rekomendacijos dèl bendrajame plane numatytų sprendinių, susijusių su žaliosios infrastruktūros kūrimu ir kraštovaizdžio formavimu, igyvendinimo. Tyrimo rezultatų analizè pateikiama B priedo B1 lentelëje.

Vilniaus miesto savivaldybės teritorijos bendrajame plane vadovaujamasi svarbiausiais trimis miesto erdvinès struktūros tobulinimo tikslais, iš kurių du glaudžiai susiję su potencialiais kraštovaizdžio architektūros veiklos lauko klausimais. Pirmame iš jų teigiama, kad būtina išsaugoti Vilniaus miesto savitumą, kuris neatsiejamas nuo kultūros paveldo (Senamiestis, istoriniai priemiesčiai) ir unikalios gamtinès aplinkos (upių šlaitai, parkai, draustiniai). Antrame - kad būtina pirmenybę teikti kompaktiško miesto sukūrimui centrinejje ir vidurinejje zonose, panaudojant vidinès plètros rezervus (antrinis teritorijų panaudojimas, modernizavimas, nebaigtų formuoti kvartalų užstatymas), plètojant viešają socialinę, susisiekimo infrastruktūrą bei želdynų sistemą (Vilniaus... 2018).

Kauno miestas bent šešis iš 13 bendrojo plano uždavinių sieja su kraštovaizdžio formavimu ir želdynų sistemos plètote. Su gyvenimo ir aplinkos kokybės gerinimo priemonėmis siejami uždaviniai, ipareigojantys suformuoti rekreacinių teritorijų, bendrojo naudojimo, apsauginių, rekreacinių ir kitų želdynų sistemą bei plètoti miesto viešujų erdvių struktūrą. Viena iš ateities Kauno vizijų - miestas su optimaliai išplètota želdynų sistema - miškais, parkais, šlaitais, žaliosiomis jungtimis, gerinančiomis aplinkos būklę ir pritaikytomis poilsiui bei rekreacijai (Kauno... 2013). Visi šie teiginiai verčia manyti, kad Kaunas renkasi šiuolaikišką miesto suvokimą per kraštovaizdị ir jị formuojančius elementus.

Klaipėdos miesto erdvinio vystymo vizijos vienas iš šešių punktų kalba apie tai, kad miesto želdynų sistema plètojama sujungiant rekreacijos, sporto ir laisvalaikio erdves bei objektus, kartu sudarant sąlygas neužstatytų teritoriju panaudojimui, jautrių gamtinių teritorijų apsaugai, tvarkymui ir pažinimui. Keturi iš dvylikos bendrojo plano tikslų apima želdynų sistemos kūrimo ir kraštovaizdžio formavimo klausimus. Tiksluose ir uždaviniuose atspindimas ryžtas formuoti rišlų miesto atvirų viešųų erdvių (aikščių, krantinių), bendrojo naudojimo želdynų (skverų, parkų), rekreacinių ir gyventojų poilsiui tinkamų gamtinių teritorijų (mieste ir užmiestyje) tinklą, numatant reikalavimus jų įrengimui, bei tobulinti esamus ir formuoti naujus miesto urbanistinès struktūros ryšius su vandens telkiniais (Klaipėdos... 2016). Aptariant Šiaulių miesto urbanistinę struktūrą teigiama, kad miestas yra stambių geosistemų sandūroje, todèl, siekiant surasti tinkamą (optimalią) pusiausvyrą tarp urbanizacinio teritorijos potencialo ir gamtinio kraštovaizdžio, siūlomas ,žaliosios kompozicinès ašies principas“ (Šiaulių... 2008). Utenos miesto erdvinę struktūrą siekiama vystyti sudarant optimalų balansą tarp urbanizuotų ir laisvų erdvių, saugant vertingą kraštovaizdị. Miesto viešosios erdvès turi būti saugios, komfortiškos ir kokybiškos. Numato- 
mas mieste esamų ežerų pakrančių sutvarkymas ir pilnavertis integravimas ị miesto struktūrą, planuojamų ir esamų miesto parkų kokybinis gerinimas, sukuriant privalomą rekreacinę infrastruktūrą. Naujai užstatomose teritorijose planuojama želdynų sistema (Utenos... 2008). Iš trijų Biržų miesto bendrojo plano uždavinių dviejuose yra integruoti želdynų sistemos, gamtinio karkaso ir kraštovaizdžio formavimo klausimai. - numatoma tobulinti istoriškai susiklosčiusią miesto urbanistinę struktūrą bei tūrinę erdvinę kompoziciją; numatyti teritorijų gyvenimo ir aplinkos kokybę gerinančias priemones, formuoti bendrojo naudojimo želdynų sistemą; numatyti priemones, užtikrinančias gamtos išteklių racionalų naudojimą, kraštovaizdžio tvarkymą, ekologinę pusiausvyrą, gamtinio karkaso formavimą, gamtos ir kultūros paveldo objektų išsaugojimą. Apibendrinant galima teigti, kad visų nagrinètų bendrujų planų tiksluose, uždaviniuose, vizijose ar principuose yra atspindimi žaliosios infrastruktūros kūrimo ir kraštovaizdžio formavimo klausimai (2.1 pav.).

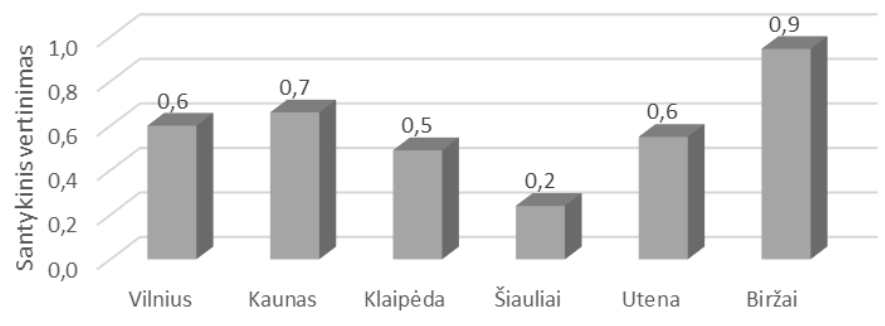

2.1 pav. Potencialių kraštovaizdžio architektūros kūrybinès veiklos klausimų atspindëjimo miesto tiksluose, uždaviniuose ar vizijose santykinio vertinimo grafinè išraiška. Šaltinis: V. Deveikienè, 2018

Fig. 2.1. The graphical expression of the potential of landscape architecture issues in the goals, tasks or visions of the city. Source: V. Deveikiené, 2018

Bendrujų planų programuojami uždaviniai dèl kraštovaizdžio tvarkymo turi dvejopą prigimtị. Iš vienos pusès tai formalūs teiginiai, besikartojantys kiekviename bendrajame plane, pavyzdžiui, ,numatyti gyvenimo ir aplinkos kokybę gerinančias priemones, formuoti bendrojo naudojimo želdynų sistemą“. Iš kitos pusès - specifiniai, labiau su konkrečiu miestu susiję siekiai. Tiek formalios tiek specifinès nuostatos yra vertingos dèl jų integralaus pobūdžio, sujungiant $\mathfrak{i}$ bendrą miesto tikslų ir uždavinių sistemą. Tyrimas parodè, kad žaliosios infrastruktūros kūrimo ir kraštovaizdžio formavimo klausimai Gamtinès aplinkos arba Kraštovaizdžio apsaugos temose geriausiai siejami su kitais urbanistiniais klausimais. Silpniausios sąsajos yra susisiekimo infrastruktūros ir inžinerinės infrastruktūros temose (2.2 pav.). 


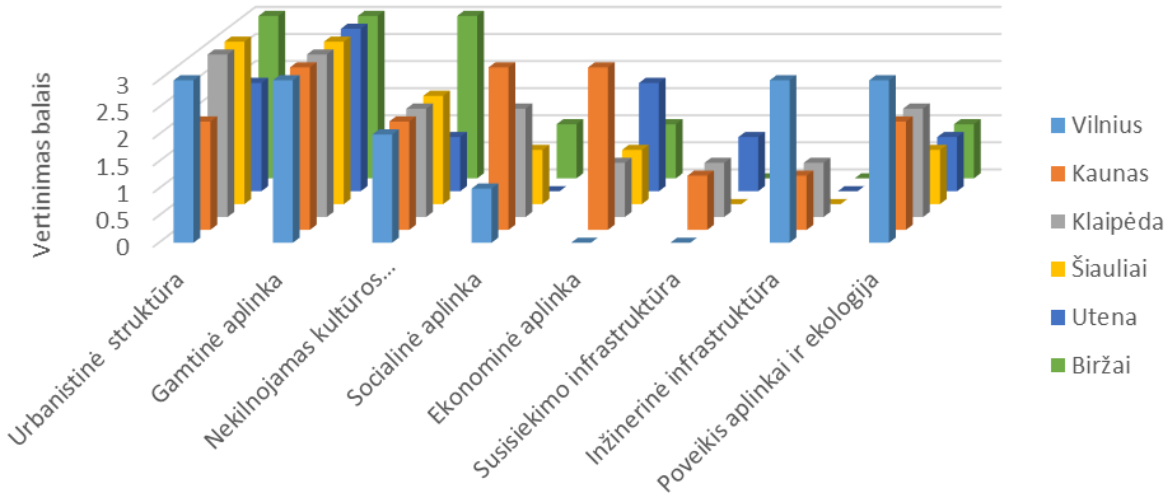

2.2 pav. Žaliosios infrastruktūros kūrimo ir kraštovaizdžio formavimo klausimu atspindejjimo kitose bendrojo plano temose grafinè išraiška. Šaltinis:V. Deveikienè, 2018

Fig. 2.2. The graphical expression of the reflexion of the issues of green infrastructure development and landscape formation in other themes of master plan of the cities. Source: V. Deveikienè, 2018

Naujai parengtame ir visuomenès svarstymui pateiktame Vilniaus miesto bendrajame plane (Vilniaus... 2018) žaliosios infrastruktūros ir kraštovaizdžio formavimo temos nagrinejjamos daug integraliau, nei iki šiol buvo ankstesniuose bendruosiuose planuose. Tekstiniuose reglamentuose, priskirtuose konkrečioms pagrindiniame brěžinyje indeksu pažymètoms funkcinėms zonoms, nustatoma, kad Savivaldybė siekia užtikrinti šių teritorijų (želdynų) viešą naudojimą. Perduodant savivaldybei dali sklypo želdynų teritorijoms formuoti, užtikrinamas želdynų sistemos rišlumas. Viešojo želdyno sklype turi būti suplanuota visa reikalinga rekreacinè infrastruktūra, atitinkanti jo lygmenị (rajoninị ar vietinị); turi būti išlaikyti BP nustatyti želdyno pasiekiamumo ir apsirūpinimo rodikliai. Nauja statyba kvartale galima tik vystytojui prisidedant prie kompleksinès kvartalo renovacijos tikslais plètojamos infrastruktūros - investuotojo léšomis rekonstruojant ir plètojant viešają infrastruktūrą (privažiavimų sistemą, želdynus, sporto ir rekreacinius aikštynus). Statant didesnius nei $20000 \mathrm{kv} . \mathrm{m}$ bendrojo ploto mažmeninès prekybos objektų pastatus, vidinèje pastatų komplekso struktūroje būtina ịrengti viešujų erdvių sistemą. Pramonès ir sandèliavimo objektams numatomose teritorijose reikia formuoti apsauginès ir ekologinès paskirties želdynus (Vilniaus... 2018). Naujasis Vilniaus miesto bendrasis planas iš esmès peržiūri ir sukonkretina numatomas želdynų normas vienam gyventojui, siekiant užtikrinti realų minimumą maždaug 200 metrų spinduliu. Nagrinëjamos atskiros situacijos, pagal užstatymo tipą ir intensyvumą. Pavyzdžiui, siūloma esamų ta- 
rybinių laikų kvartalų laisvo planavimo principą (2.3 a pav.) modifikuoti, siekiant atskirti viešąsias ir privačias (gatvių ir kiemų) erdves. Ten pat nurodoma, kad savivaldybė užtikrina viešujų erdvių ir vietinių želdynų tinklo, jungiamo pėsčiujų ir dviračių takais, kūrimą. Vieši želdynai ar viešosios erdvès privalo būti pasiekiami $200 \mathrm{~m}$ nuo būsto atstumu. Konkrečiu atveju siūloma minimali želdynų norma $-3 \mathrm{kv} . \mathrm{m} /$ gyventojui. Gatvių ir pėsčiųjų promenadų erdvėse kuriamos želdynu juostos. Naujai planuojamuose daugiabučių namų kvartaluose (2.3 b pav.) rekomenduojama užstatymo struktūrą formuoti atskiriant viešas ir privačias erdves.

a)

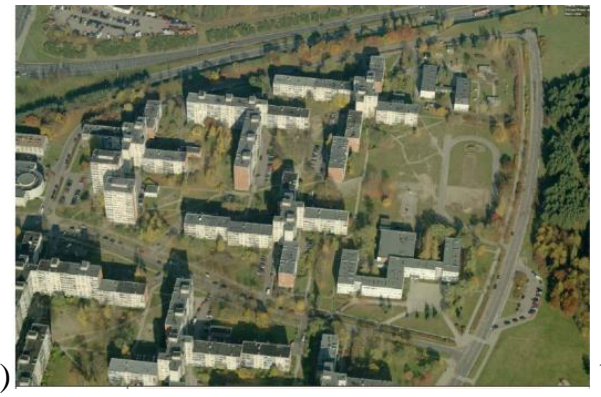

b)

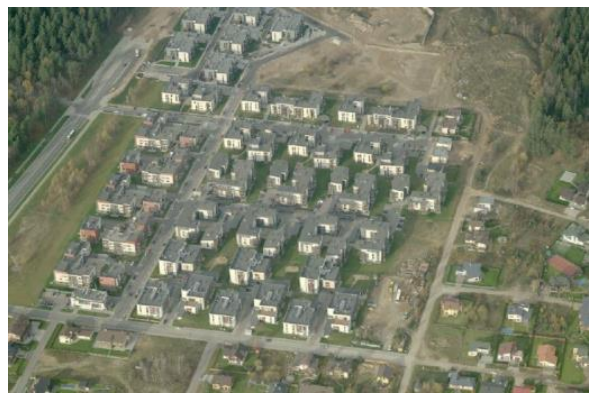

2.3 pav. Vilniaus miesto užstatymo tipų pavyzdžiai: a) laisvo planavimo užstatymas;

b) naujai planuojami daugiabučių namų kvartalai. Šaltinis: Vilniaus miesto savivaldybès teritorijos bendrasis planas, 2018

Fig. 2.3. Two examples of types of building areas in Vilnius city a) the building of free planning; b) Newly-planned blocks of flats. Source: Master Plan of the Vilnius City Municipality, 2018

Pažymima, kad prioritetinès plètros teritorijose savivaldybė užtikrina viešųjų erdvių ir vietinių želdynų kūrimą. Neprioritetinès plètros teritorijose viešąsias erdves ir vietinius želdynus įrengia nekilnojamojo turto vystytojai. Vieši vietiniai želdynai ar viešosios erdvès privalo būti pasiekiami 200 m nuo būsto atstumu; jų minimali norma - 3-4 kv. m/gyventojui. Gatvių ir pėsčiųu promenadų erdvèse kuriamos želdynų juostos. Šios nuostatos kuria gana aktyvios sąveikos tarp savivaldybės, vystytojų, projektuotojų ir būsimų vartotojų poreikị. Tuo pačiu kuriamas poreikis savalaikiams kraštovaizdžio architektūros sprendiniams tiek planavimo, tiek urbanistinio projektavimo stadijose.

Nauja yra ir tai, kad Vilniaus bendrajame plane yra aptariamos esminès hidrogeologinès sąlygos, lemiančios statybų perspektyvumą, intensyvumą ir jų sprendinius. Tekste teigiama, kad upių slèniuose labai svarbūs tarpterasiniai šlaitai-pakopos. Nustatomas I-mų viršsalpinių terasų tvarkymo reglamentas. Jame teigiama, kad urbanizuotose I-ose terasose, vykdant rekonstrukciją, konversiją ar statant naujus pastatus, būtina hidrogeologinè ekspertizè. Nustatomas vizualinę 
pakrančių miestovaizdžio apsaugą užtikrinantis užstatymo intensyvumo ir aukštingumo reguliavimas. Kaip ir salpose - I-osiose terasose, prie pakrančiu įtvirtinamas viešojo naudojimo prioritetas - įrengiami takai-jungtys. Ten, kur yra naudojimo potencialas, didžiausias palankumas teikiamas želdynams su intensyvia poilsio ir sporto infrastruktūra, miesto daržininkystei (angl. urban agriculture). Planuojant laikomasi principinès nuostatos: ,gamtinių elementų - tiek, kiek galima, dirbtinių - tiek, kiek būtina“" (Vilniaus... 2018).

Inžinerinès infrastruktūros dalyje pateikiamas alternatyvus siūlymas lietaus vandeniui tvarkyti. Autoriai teigia, kad, mieste daugèjant kietų dangų, vandens sutekèjimai intensyvėja, tačiau Vilniaus miesto paviršinių nuotekų sistema visiškai neturi rezervo. Skatintinas supratimas, kad dali sklypo paskiriant žaliam plotui, užtikrinamas ne tik vandens kaupimas, bet ir gerinama ekologine bei rekreaciné aplinka. Vilniaus bendrajame plane pateikiama nauja integrali gamtinio karkaso stiprinimo priemoné - nelaidžių dangų (ND) kontrolès modelis, kuriuo siekiama reguliuoti miesto teritorijos paviršių laidumą (2.4 a pav.).

a)

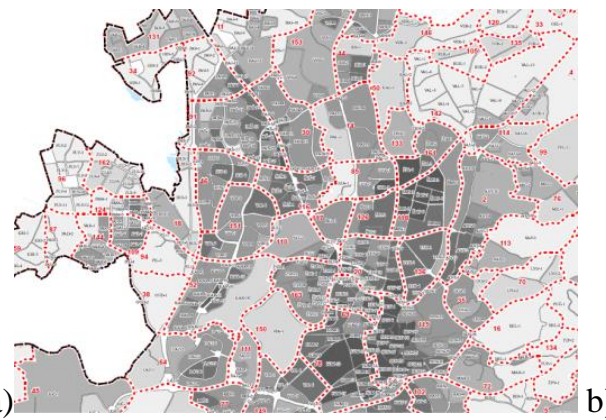

b)

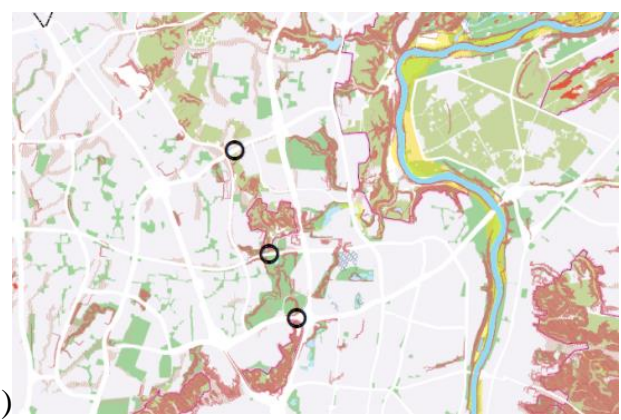

2.4 pav. Vilniaus miesto bendrasis planas: a) Vilnius m. dangų laidumo vandeniui žemėlapio ištrauka; b) gatvėmis perkirsto gamtinio karkaso taškai Vilniaus mieste. Šaltinis: Vilniaus miesto savivaldybès teritorijos bendrasis planas, 2018

Fig. 2.4. Master plan of Vilnius city: a) Extract of the map on the permeability of surfaces for rainwater; b) The points where the natural network of citiy is broken by streets. Source: Master plan of the territory of Vilnius municipality, 2018

Vilniaus bendrajame plane pripažistama taisyklè, kad privalomas visų kategorijų susisiekimo koridorių, kaip viešujų erdvių, apželdinimas, suteikiant jiems ekologinę (kartais - ir rekreacinę) pridètinę vertę. Teigiama, kad susisiekimo koridorių plètra mieste atkreipia dèmesị i tinklų - žaliojo ir urbanistinio - sąveiką. Žaliaji tinklą formuoja tiek svarbiausi gamtinio karkaso elementai, tiek žmogaus sukurti ar papildyti dariniai - urbanizuotu masyvų žaliosios jungtysperskyros. Žaliajji tinklą paprastai perkloja urbanistinis ir jị sudalina $\mathfrak{i}$ atskiras dalis (2.4 b pav.) Žaliujų jungčių-perskyrų fragmentacija sumenkina jų ekologinị 
ir rekreacinį-komunikacinị potencialą. Nežiūrint siekiamybės labiau susieti gamtinị ir urbanistinị karkasus, naujame bendrajame plane atsisakoma ankstesniuose planuose numatytų kai kurių žaliųu jungčių. Šis sprendimas motyvuojamas faktinèmis urbanistinès plètros paveiktomis teritorijų transformacijomis, patvirtintais teritorijų detaliujų planų sprendiniais, prarastu gamtiniu potencialu ir kt. Taip atsisakoma žaliujų jungčių-perskyrų: būsimos Šiaurinès gatvės; jungties nuo Bajorų-Visorių miško (per Ukmergès g. ir Vakarinio aplinkkelio sankryžą ir Pavilionis) iki Sudervès upelio slènio (Vilnius... 2018). Šis apsisprendimas liudija planuotojų bejègiškumą teisinių ir etinių prieštarų akivaizdoje, prioritetų vienpusiškumą, kritinio mąstymo ir alternatyvių sprendimų trūkumą. Kita vertus tai iliustruoja integralių sprendinių bendrojo plano lygmenyje būtinybę, nes minètos žaliosios jungties sprendinys nefigūravo transporto ir kitose plètros temose, išskyrus želdynų dalį. Formuojant sklypus ir rengiant detaliuosius planus nebuvo kreipiamas dèmesys ị žaliosios jungties siūlymą, nes šis sprendinys nebuvo susietas ir tinkamai reglamentuotas santykyje su kitais urbanistiniais sprendiniais.

Kauno miesto bendrasis planas pasižymi ir išsiskiria iš kitų nagrinètų miestų bendrujų planų integraliu požiūriu, žaliosios infrastruktūros kūrimo ir kraštovaizdžio klausimus priskirdamas socialinei ir ekonominei aplinkai. Pavyzdžiui, kalbėdami apie stambiaplokščių namų kvartalų renovaciją autoriai teigia, kad kartu su daugiabučių namų renovacija kompleksiškai turi būti vykdoma parengta daugiabučiu namų kiemų infrastruktūros bei želdynų gerinimo programa. Tokiuose kompleksiniuose teritorijų planavimo dokumentuose turi būti numatyti kvartalo perplanavimo (ịskaitant ir galimą pastatų perstatymą) sprendiniai, gyvenamosios aplinkos gerinimo sprendiniai (priklausomujų želdynų sutvarkymo, kiemų infrastruktūros sutvarkymo, inžinerinès infrastruktūros (tinklų) atnaujinimo, kvartalo viešųų erdvių ir objektų įrengimo, privatizavimų sutvarkymo ar irengimo ir pan.). Svarbi Kauno bendrojo plano nuostata, kad Valstybès ir savivaldybès poreikiams naudojamomis teritorijomis pripažịstamos ne tik miesto gatvès, visuomeninès teritorijos ar krašto apsaugai naudojamos teritorijos, bet ir rekreaciniai atskirieji želdynai, kapinès, miesto miškai, valstybinis vandenų fondas (B priedas B1 pav.). Šios teritorijos parodytos rezervuojamų valstybės poreikiams teritorijų brěžinyje (M 1:25 000), nurodant, kad konkretūs sprendimai dèl valstybès ir savivaldybès poreikiams rezervuojamų teritorijų turi būti priimti rengiant žemesnio lygmens teritorijų planavimo dokumentus ir techninius projektus (Kauno... 2013).

Vienintelis iš visų nagrinètų bendrujų planų Kauno bendrasis planas želdynų ir miškų bei vandens temas nagrinejja rekreacijos problematikos kontekste ekonomikos aplinkoje. Mišraus užstatymo teritorijose esančių gamybinių teritorijų, išsidèsčiusių šalia upių (Petrašiūnuose, Vilijampolejje, Fredoje), konversijos atveju rekomenduojama numatyti priejjimus prie upès, skirtus viešam naudojimui. Ekonomikos temoje analizuojami viešieji rekreaciniai ir viešieji su rekrea- 
cija susiję objektai: želdynai, rekreaciniai miškai, vandens telkinių pakrantès, viešieji sporto kompleksai, viešosios laisvalaikio ir aktyvaus poilsio infrastruktūros teritorijos. Šioje dalyje taip pat pateikiama informacija tik apie tuos dviračių ir pėsčiujų takų sprendinius, kurie yra reikalingi išskirtų rekreacinių zonų vidiniams ryšiams užtikrinti. Ryšiai - dviračiu takai, vandens transporto trasos ir infrastruktūra (įskaitant prieplaukas) - yra analizuojami BP susisiekimo sistemos dalyje. Ekonomikos temoje taip pat pabrèžiama, kad Kaune vandens telkiniai nèra pakankamai pritaikyti rekreacijai, miestą kertančios upès neišnaudojamos laivybai ir vandens turizmui. Naujai formuojamose (tvarkomose) vandens telkinių pakrančių teritorijose, ten, kur leidžia esamas užstatymas ir suformuoti sklypai, prie vandens telkinių formuojamos ne mažesnès kaip po $10 \mathrm{~m}$ pločio viešo priejjimo prie vandens telkinių zonos, jose suformuojant želdynus su pėsčiujų ir (arba) dviračių takais. Tokiose naujai formuojamose teritorijose, o taip pat konversijos atveju šalia pakrančiu esančiose konvertuojamose teritorijose gatvès, akligatviai, vedantys link vandens telkinių pakrančių, negali būti uždaromi sklypais, jie turi būti sujungti su vandens telkinių pakrančių takais (Kauno... 2013). Galima teigti, kad vandens telkinių rekreacinis panaudojimas yra tiesiogiai susiję su pakrančių tvarkymu, t. y. su kraštovaizdžio architektūros uždaviniais.

Klaipėdos miesto bendrajame plane želdynų sistema ir kraštovaizdžio formavimas traktuojami kaip sudètinè urbanistinès struktūros dalis. Ypatingas dèmesys skiriamas miesto siluetui, panoramoms ir prieigoms prie vandens. Pripažistama, kad viešujų erdvių ir želdynų sistema yra svarbus miesto urbanistinès struktūros komponentas, palaikantis ekologinị stabilumą, gerinantis žmonių gyvenamosios ir darbo aplinkos sąlygas. Tačiau čia pat pastebima, kad esama gamtinẻ struktūra stokoja sistemingumo, tarp atskirų viešųjų erdvių, želdynų trūksta žaliụjų jungčių. Šiaurinè ir pietinè miesto dalys nesudaro bendros sistemos, o šiaurinèje miesto dalyje, gyvenamuosiuose rajonuose visiškai nèra įrengtų atskirujų želdynų. Nepaisant to, esama Klaipėdos viešųjų erdvių sistema turi itin didelị potencialą plètotis, dèl neišnaudotų gamtinių resursų gausos. Pavyzdžiui, kaip teigia autoriai, ypač trūksta Danès upès, Smeltalès upelio integracijos i bendrą miesto želdynų sistemą, šių teritorijų plètojimo ir infrastruktūros kūrimo. Gamtinius rekreacinius išteklius Klaipėdos miestas traktuoja, kaip vieną iš svarbiausių turizmo ir rekreacijos organizavimui reikalingų išteklių grupę, kurią sudaro gamtiniai kraštovaizdžio elementai ir jų dariniai: vandens telkiniai (jūra, marios, ežerai, tvenkiniai, upès ir upeliai), želdiniai (miškai, miško parkai, parkai), saugomos bei kitos gamtinès teritorijos ir vertybès bei vaizdingas (aukšto estetinio potencialo) kraštovaizdis. Pastebima, kad dèl intensyvios chaotiškos urbanizacijos sklaidos bei didelès architektūrinių sprendinių įvairovès nukenčia ir estetinis kraštovaizdžio potencialas, siūloma problemas spręsti statinių architektūrinių sprendimų reglamentavimu. Inžinerinès infrastruktūros dalyje teigiama, kad požiūris i paviršinio vandens surinkimą ir transportavimą i paviršinio 
vandens telkinius turètų būti iš esmès keičiamas. Siūloma urbanizuotuose ir planuojamose urbanizuoti teritorijose ịrengti lietaus vandens valyklas ir kaupyklas, jas numatant teritorijų planavimo dokumentuose.

Šiaulių miesto bendrajame plane ryškiausiai išsiskiria miesto urbanistinès struktūros koncepcija, kur akcentuojami miesto istorinis struktūrinis branduolys senamiestis ir kompozicinè miesto žalioji ašis (B priedas, B2 pav.). Fiksuojama miesto vizualinio identiteto zona, kuri padeda identifikuoti pačius vertingiausius vaizdus ir vaizdo elementus, kuriuos būtina saugoti. Šiaulių miesto teritoriją sīuloma nagrinèti kaip urbanizuotų ir neurbanizuotų teritorijų visumą. Sąvokos „urbanizuotos teritorijos“ ir „neurbanizuotos teritorijos“ miesto kontekste turbūt atitiktų užstatytos ir neužstatytos teritorijos sąvokas. Tendencija ,ieškoti visumos" yra labai pažangi. Tačiau čia pat iškeliama tik urbanistinès struktūros architektūrinio-estetinio aspekto svarba. Apsiribojama tik architektūrineurbanistine miesto kompozicijos analize (Šiaulių... 2008). Turint galvoje siūlomą kertinę miesto žaliosios ašies idejją, iš esmès yra pasirenkamas miesto formavimo per kraštovaizdi kelias, kurị nuosekliai iggyvendinant reikètų papildyti urbanistinès struktūros analizès aspektų sąrašą šalia architektūrinio-estetinio lygiagrečiai taikant ekologinị bei socialinị aspektus. Tada būtų galima nuosekliai rinktis kraštovaizdžio architektūros metodus ir priemones, kurie padètų igyvendinti ir darnaus miesto tikslus ir uždavinius. Šiaulių bendrojo plano Inžinerinès infrastruktūros temoje teigiama, kad lietaus vandens surinkimo ir valymo sistema yra mažiausiai išplètota miesto inžinerinès infrastruktūros sritis, o reljefo nelygumai kelia didelius reikalavimus lietaus vandens surinkimui (Šiaulių... 2008). Tačiau paviršinio lietaus vandens tvarkymo koncepcijos nesiūloma. Vertinant sprendinių integralumo požiūriu, „mažai išplètota lietaus vandens surinkimo sistema" kaip tik sudaro prielaidas ieškoti alternatyvių lietaus vandens tvarkymo priemonių. Žalioji ašis ir želdynų sistema galètų pasitarnauti ne tik estetinei-ekologinei urbanistinei kompozicijai, bet ir tuo pačiu būti lietaus vandens tvarkymo karkasine struktūra. Bendrajame plane kaip tik galètų būti priimtas kertinis sprendimas sujungti ir koordinuoti ivairių sričių urbanistinius veiksmus, juos nukreipiant ị žaliosios ašies visapusišką vystymą.

Utenos miesto želdynų sistemos vystymas buvo pradètas nuo logiškos ir aiškios miesto želdynų schemos (aut. R. Pilkauskas ir A. Žickis, 1999) parengimo. Ši schema vẻliau sẻkmingai ir nuosekliai buvo ịtraukta ị bendrojo planavimo procesą ir dokumentus - Utenos BP (Utenos miesto... 2008). Utenos miesto BP gali būti pavyzdžiu dèl miesto gamtinio karkaso pagrindinių dalių - išorinių ekologinio stabilizavimo arealų, migracijos koridorių ir vidinių ekologinio stabilizavimo arealų sukonkretinimo įvardinant ir lokalizuojant kraštovaizdžio objektus. Pabrèžtinas racionalus sprendimas kiekvienoje iš paminètų miesto gamtinio karkaso dalių numatyti teoriškai galimus penkis skirtingus tvarkymo tipus, kurie surikiuoti tvarkymo priemonių masto bei intensyvumo mažejimo linkme: naujo 
želdyno ịrengimas; esamos želdyno sistemos ịrengimo lygio ir būklès gerinimas; esamos želdyno sistemos ịrengimo lygio ir būklès palaikymas; natūralaus kraštovaizdžio pobūdžio atkūrimas; natūralus kraštovaizdžio pobūdžio palaikymas ir saugojimas (Utenos miesto... 2008). Bendra žaliosios infrastruktūros sistemos Utenoje tvarkymo nuostata - žaliujų plotų sistema yra nepaprastai svarbi ir neatskiriama miesto urbanistinès struktūros dalis, kuri yra formuojama siekiant išsaugoti visuomeniškai ir ekologiškai vertingo gamtinio kraštovaizdžio plotus, jų visumą tvarkyti kaip teritorinę sistemą, siekiant gerinti ekologines bei rekreacines gyvenamosios aplinkos sąlygas, kuriant patrauklaus miesto įvaizdị. Tokie siekiai yra ịvertinti ne tik Lietuvos, bet ir Europos mastu - Utenos miestas yra pelnęs specialujji Europos Tarybos Europos kraštovaizdžio konvencijos 20122013 metų žymenį už kraštovaizdžio išteklių saugojimą ir gausinimą.

Biržų miesto bendrojo plano sprendiniai yra siejami su gamtos paveldo apsaugos reikalavimais ir atitinka aplinkos tvarkymo tikslus, nustatytus Lietuvos ratifikuotoje Europos kraštovaizdžio konvencijoje (2002): (1) įteisinti kraštovaizdị kaip svarbią žmones supančios aplinkos sudedamają dalị, jų bendro kultūros ir gamtos paveldo apraišką bei jų savasties pagrindą; (2) integruoti kraštovaizdį kaip reiškini i c savo teritorijų ir miestų planavimo politiką bei savo kultūros, aplinkos, žemès ūkio, socialinę ir ekonominę politiką, taip pat ị kiekvieną kitą politikos srití, galinčią turèti poveikị kraštovaizdžiui; (3) nustatytus kraštovaizdžius ịvertinti, atsižvelgiant ị suinteresuotų dalyvių ir atitinkamos gyventojų grupés jiems priskiriamą ypatingą vertę. Būtent, atsižvelgus ị visuomenès dalyvavimo svarbą, jos nuomonę, išreikštą pradiniuose visiems rūpimų klausimų sprendimo etapuose, ir buvo organizuotos (2015 m. ruduo) kūrybinès dirbtuvès „Biržų viešujų erdvių vizija“ (B priedas, B3 pav.).

Apibendrinant atliktą tyrimą galima teigti, kad teritorijų planavimo procese dedami urbanistinių sprendinių ir kraštovaizdžio architektūros sąveikos pagrindai ir programuojama tolesnè bendradarbiavimo seka ir prioritetai. Urboekologiniu ir urbanistiniu požiūriu pagrịstos miesto žaliosios infrastruktūros, želdynų sistemos bei miesto urbanistinès struktūros formavimą lemia vietos gamtinès sąlygos. Gamtinio karkaso lokalizavimas mieste yra labai svarbus etapas, nes taip sukuriama vientisa ekologinio kompensavimo sistema. Siekiant integralumo miesto teritorijose, gamtinio karkaso lokalizavimo ir projektavimo procesas turi aprèpti gamtinių ir urbanistinių struktūrų sandus, kurių sąveika analizuotina pagal išskirtus tris gamtinio karkaso mieste prioritetus: ekologinio kompensavimo, socialiai orientuotos rekreacinès paskirties ir architektūrinio kompozicinio (estetinio poveikio) vaidmens. Šiuolaikiniam miestui reikalinga urbanistinio karkaso ir gamtinio karkaso tausojanti sąveika. Tyrimas parode, kad visuose nagrinètuose bendruosiuose planuose daugiau ar mažiau yra numatomos priemonès ir pateikiamos rekomendacijos tolimesniam sprendinių, susijusių su žaliosios infrastruktūros kūrimu ir kraštovaizdžio formavimu, igyvendinimui. Šios priemonès 
dažniausiai yra susijusios su ịpareigojimu rengti žemesnio lygio teritorijų planavimo dokumentus, programas ir pan. Lietuvos miestų bendrujų planų rengejjai turi visas teisines priemones (pvz., kompleksinio teritorijų planavimo dokumentų rengimo taisyklès 2014) ir galimybes atlikti ekologinio tinklo arba žaliosios infrastruktūros ir želdynų sistemos integralų planavimą, abipusiai sprendinius siejant su kitomis bendrojo plano temomis ir taip programuojant urbanistinių ir kraštovaizdžio architektūros sprendinių sąveikos ir abiejų sričių profesionalų kūrybinio bendradarbiavimo pagrindus žemesnio lygmens planavimo ar projektavimo procesuose.

Tyrimas atskleidè, kad visuose analizuotuose bendruosiuose planuose yra numatyta uždavinių dèl gamtinio karkaso lokalizavimo, želdynų sistemos vystymo, kraštovaizdžio formavimo, kurie iš esmès yra susiję su kraštovaizdžio architektūros profesine veikla ir kompetencijomis. Tačiau nẻ vienas išnagrinètas bendrasis planas nekalba apie galimybę ar poreikị taikyti kraštovaizdžio architektūros principus ir priemones konkretiems uždaviniams spręsti. Vieninteliame Vilniaus miesto bendrajame plane vienoje vietoje yra paminèta kraštovaizdžio architektūra, nurodant, kad pagrindinejje miesto dalyje parkų ir skverų irengimo bei pertvarkymo projektai turètų būti pasirenkami kraštovaizdžio architektūros konkursų būdu. Tyrimo autorès nuomone, siekiant tvaraus miesto tikslų būtina optimizuoti kraštovaizdžio architektūros ir urbanistikos sprendinių sąveiką, iš anksto numatant miesto vystymo uždavinius, kuriems spręsti reikès kraštovaizdžio architektūros kompetencijų, metodų ir priemonių. Bendrųu planų tyrimas išryškino kraštovaizdžio architektūros ir urbanistinių spendinių sąveikos optimizavimo kriterijus miesto lygmenyje - teritorijų ekologinio pajègumo, žaliujų erdvių vientisumo, sistemiškumo kriterijus, socialiniu aspektu - pasiekiamumo, integracijos, funkcijų sinergijos, estetiniu aspektu - esminių miesto vertybių apsaugą, metodinius estetinių poreikių kodavimus. Tik bendrojo plano sprendiniais galima iš anksto nustatyti esminius prioritetus ir užtikrinti ekologinių, socialinių ir estetinių kriterijų integralaus sinerginio veikimo pagrindus.

\subsection{Ekspertų nuomonių tyrimas apie kraštovaizdžio architektūros vaidmenị miesto kūrimo procese}

Kraštovaizdžio architektūros ir urbanistikos sąveikos procese svarbų vaidmenị atlieka miesto planavime, projektavime ir tvarkyme dalyvaujantys specialistai. Kaip parodè mokslinès literatūros analizè ir pasirinktų Lietuvos miestų bendrụjų planų aiškinamujų raštų ir sprendinių tyrimas, miesto aplinkos kokybės klausimus lemia kraštovaizdžio architektų, urbanistų ir pastatų architektų nuoseklus ir kūrybiškas bendradarbiavimas. Todèl tolimesniame tyrimo etape norèta sužinoti šių sričių patyrusių specialistų, savo dalyko ekspertų nuomonę tam tikrais tyri- 
mui svarbiais miesto kraštovaizdžio formavimo klausimais. Buvo pasirinktas sociologinių tyrimų grupès metodas -pusiau struktūruota apklausa-ekspertinis interviu. Šiame tyrime taip pat buvo taikytas ekspertinès apklausos Delphi metodas (angl. Delphi method), kurio principas - kartotinè skirtingų sričių ekspertų grupių apklausa tyrimui rūpimais klausimais, prieš tai juos supažindinant su ankstesnès apklausos rezultatais. Tyrimas susideda iš trijų etapų ekspertinių apklausų. Ekspertų nuomonès tyrimas vyko paraleliai kitiems šiame moksliniame darbe vykdomiems tyrimams, todèl abipusiai turèjo ịtakos pereinant iš vieno tyrimo etapo i kitą - taip pat ir papildant ar pakoreguojant klausimus ekspertams. Kiekviename iš ekspertinès apklausos etapų įvairioms profesinèms grupèms buvo pateikiami tie patys klausimai. Apdorojant ir analizuojant duomenis buvo naudojama Excel programine įranga. Analizuojant ir apibendrinant rezultatus buvo išlaikomas profesinių grupių aspektas. Taikant palyginamosios analizės principus išnagrinètos ir palygintos skirtingu profesijų ir veiklos atstovų nuomonès. Temos aktualumą pagrindžia vis labiau įsigalintis socialinès dimensijos akcentavimas aplinkos formavimo ir tvarkymo, urbanistikos ir architektūros srityse. Pirmojo ekspertuc apklausos tyrimo etapo rezultatai pristatyti autorès publikacijoje „Kraštovaizdžio meno raiškos mieste svarba pagal tikslinès apklausos rezultatus" (Deveikienè 2018).

Pirmasis tyrimo etapas atliktas 2016 m. rugpjūčio 19 d. Rietave vykusio profesinio seminaro „Istorinio parko ir miesto sąveika - gerosios praktikos eskizas“ dalyvių apklausos pagrindu. Šiame etape buvo paruoštos popierinès anketos ir išdalintos seminaro metu. Pačiame seminare gvildenti klausimai tik iš dalies siejosi su klausimynu, tačiau bendraja prasme kraštovaizdžio architektūros ir urbanistikos sprendinių sąveikos problematika buvo nagrinejjama. I anketos klausimus atsake 25 seminaro dalyviai, iš kurių 6 architektai, 7 kraštovaizdžio architektūros specialistai. Visos kitos profesijos (12) - dailès pedagogas, fotografas, paveldosaugininkas, ekonomistas, kompiuterių specialistas, finansininkas, studentas, hidrotechnikas, viešojo administravimo ir projektų vadybos specialistas - turèjo po vieną arba du atstovus. Iš esmès respondentai pasiskirstė beveik per pusę - keturiolika žmonių vienaip ar kitaip tiesiogiai dalyvaujančių miesto kraštovaizdžio formavime ir vienuolika respondentų, kuriuos laikytume vartotojais. Šis pasiskirstymas ịdomus rezultatų analizès prasme, nes atspindi skirtingą santykį su kraštovaizdžiu turinčių žmonių nuomonę. Apklausos anketos klausimai buvo formuluojami pradedant nuo miesto, gatvès ir kvartalo raišką ar erdvinị vaizdą lemiančių kompozicinių formantų. Buvo pateikta po šešis atsakymo variantus ir paprašyta juos sureitinguoti nuo vieno iki šešių arba septynių, jeigu bus pasiūlytas ir pačių respondentų variantas. Toliau buvo klausiama, kas, respondentų nuomone, yra kraštovaizdžio architektūros kūrybos objektas, pateikiant keletą variantų ir paprašant tinkamus pažymèti, taip pat pasiūlyti savo. Šis klausimas iškeltas dèl to, kad net ir tarp profesionalų vis dar labai nevienodai 
suprantamas kraštovaizdžio architekto veiklos laukas, todèl rūpejjo išgirsti profesiškai margos auditorijos nuomonę. Tokios pat struktūros klausimas pateiktas ir norint išgirsti nuomonę dèl kraštovaizdžio architektūros objekto vaidmens urbanistinejje aplinkoje bei ịtakos visuomenès ekonominiam ir socialiniam gyvenimui. Paskutiniai du klausimai buvo atviri - buvo prašoma pateikti pozityvaus kraštovaizdžio architektūros objekto poveikio pavyzdžių ir pateikti keleto objektų, esančių artimiausioje respondentų aplinkoje, pavadinimų.

I klausimą, kas lemia miesto raišką, reitingavimui pateikti šie kompoziciniai elementai: pastatai, reljefas, gatvès, miško masyvai, inžineriniai statiniai ir vandens telkiniai (2.5 pav.).

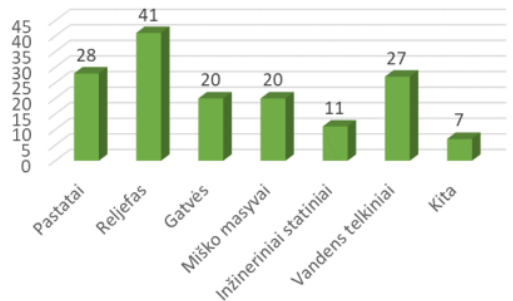

a)

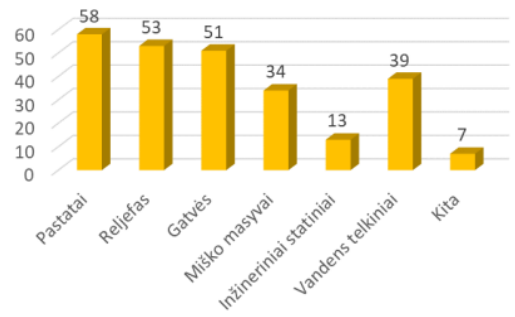

c)

2.5 pav. Atsakymų i klausimą, kokie elementai lemia miesto raišką, diagramos pagal respondentų grupes: a) kraštovaizdžio architektai ir inžinieriai; b) architektai; c) kitų profesijų atstovai; d) bendri rezultatai. Šaltinis: V. Deveikienè

Fig. 2.5. The answers to the question about the elements that determine city's expresion, graphs by respondent groups: a) landscape architects and engineers; b) architects; c) other professions; d) overall results. Source: V. Deveikienè

Klausimo dèl miesto raišką lemiančių elementų atsakymų analizès išvada, kad reljefas, pastatai ir vandens telkiniai yra labiausiai žmonèms suvokiami ir pastebimi miesto raišką formuojantys elementai, todèl jų sąveika turètų būti stiprinama ir harmonizuojama, ypač naudojant kraštovaizdžio architektūros priemones ir principus. Miško ar želdinių masyvai turètų būti geriau integruojami ị miesto erdvinę struktūrą, ieškant kompozicinès sąveikos su kitais miesto struktūriniais elementais. 
Antruoju klausimu norèta sužinoti, kam prioritetas teikiamas formuojant gatvès erdvinị vaizdą. Reitingavimui buvo pateikti šie gatvèje dažniausiai matomi objektai: pastatai, medžiai, reklama, gèlynai, meno kūriniai, baldai ir ịrenginiai. Visos respondentų grupès pirmą vietą skiria pastatams, antrą - medžiams, trečią - gèlynams. Atsakymai rodo sinergijos tarp pastatų ir gatvès nevažiuojamosios dalies, kuri iš esmès kuriama kraštovaizdžio architektūros priemonėmis, svarbą. Anketoje apie gatvès erdvinị vaizdą pateiktame klausime sąmoningai nebuvo įvardintos gatvès kategorijos, nuo kurių, be abejo, priklauso gatvès parametrai. Toks abstraktus klausimas leido gauti pirminị intuityvų atsakymą, kaip žmonès supranta gatvę, o jų nuomonè praktiškai atitinka humaniško miesto gatvès sampratą, kurią išsako garsūs gyvenimo mieste tyrinètojai J. Jacobs (1992), J. Ghel (2010), R. Allain (2004) ir kt.

Klausiant kas kuria kvartalo ịvaizdị, reitinguoti buvo pateikti šie reiškiniai pastatų architektūra, privažiavimai, viešosios erdvès, želdiniai, vidiniai kiemai, inovatyvi inžinerija. Pirmąsias tris vietas visos respondentų grupès skyrẻ beveik vieningai - pirma vieta pastatų architektūrai, antra ir trečia vietomis dalijasi viešosios erdvès ir želdiniai. Visi respondentai viešajai erdvei suteikè didesnę svarbą negu kiemams, matyt, ir dèl to, kad buvo klausiama apie kvartalo ịvaizdị. Faktas, kad viešosios erdvès reikšmè ịvertinta mažiau negu pastatų, interpretuotinas tuo, kad viešosios erdvès architektūrinę išraišką, priklausomai nuo situacijos, formuoja ją supančių pastatų fasadai, želdiniai, ịvairūs ịrenginiai, meniniai akcentai ir kt. Nežiūrint daugybès kompozicinių elementų, viešosios erdvès sẻkmé slypi ne atskirose detalèse, o jų bendroje kompozicijoje ir jos sąryšyje su supančiais vaizdais. Aplinkinių vaizdų integravimas ị bendrą kompoziciją yra vienas svarbiausių kraštovaizdžio architektūros principų, kurio taikymo sẻkmé pagrịsta pasirinktų kompozicijos elementų kokybinès sąveikos su supančia aplinka paieška.

Atsakymų i pirmosios grupès klausimus analizès ir interpretacijos išvada yra ta, kad miesto erdviniam charakteriui didžiausią reikšmę turi reljefas, vandens telkiniai ir pastatai, o jų sąveikos subtilybès lemia urbanistinio kraštovaizdžio kokybę. Miesto struktūrinio elemento gatvès erdviniam vaizdui lemtingos įtakos turi pastatai ir medžiai ir, be abejo, reljefas. Atsakymų i anketos klausimus suvestinè pagal respondentų grupes pateikiama B priedo B2 lentelèje.

Visos respondentų grupès kraštovaizdžio architektūros objektui vienareikšmiškai priskiria želdynų sistemą. O tai reikštų, kad kraštovaizdžio architektūros profesijos kompetencijos yra reikalingos pradedant strateginiu ir miesto planavimo lygmenimis, kur želdynų sistema užgimsta, toliau - urbanistiniame projektavime, kur želdynų sistema konkrečiais sprendiniais yra integruojama ị kvartalus, jai yra suteikiamas koncepcinis pavidalas, nustatomi funkciniai prioritetai, ribos ir pan. Projektuojant konkrečius objektus želdynų sistema kuriama atski- 
romis dalimis. Iš esmès šią eigą paliudija kiti respondentų prioritetiniai atsakymai, kraštovaizdžio architektūros objektui priskiriant parkus ir viešąsias erdves.

Klausiant, kaip kraštovaizdžio architektūros objektas gerina urbanistinę aplinką, pasiūlyti keli plačiajai visuomenei suprantami teigiamos sąveikos variantai: sukuria foną pastatams; harmonizuoja pastato ryši su aplinka; kuria kvartalo erdvinę išraišką; kuria meniškus vaizdus; estetizuoja inžinerinius sprendinius; integruoja gamtinius elementus; kuria gatvès erdvinę struktūrą. Apibendrinant respondentų nuomonę, kraštovaizdžio architektūros objekto svarbiausia reikšmé yra ta, kad jis harmonizuoja aplinką su pastatais. Harmonija yra viena iš svarbiausių žmogaus dvasinio ir materialinio gyvenimo kokybės kategorijų. Miesto kontekste harmonizavimas yra siejamas su aplinkos turtinimu (Jurkštas 1994). Šis pasirinkimas rodo, kad kraštovaizdžio architektūra formuojant miestą atlieka labai svarbų gyvenimo kokybès gerinimo vaidmenį.

Didžioji dalis respondentų ị klausimą, ar kraštovaizdžio architektūros objekto kuriama urbanistinès aplinkos kokybė turi įtakos ekonominiam ir socialiniam visuomenès gyvenimui, atsakè „taip“. Respondentai taip pat pateikẻ keletą kraštovaizdžio architektūros pozityvaus poveikio aplinkai pavyzdžių. Apibendrinant respondentų nurodytus kraštovaizdžio architektūros objekto pozityvaus socialinio poveikio patvirtinimus, buvo nustatytos tam tikros nuomonių tendencijos. Profesionalai linkę ịžiūrèti didaktinị (auklèjamajị) vaidmenị visuomenei, o patys atsakymai turi hipotetini pobūdį. Tuo tarpu kitų profesijų respondentai pateikia daugiau asmeninio išgyvenimo atsakymų, kurie yra patikrinimo nereikalaujantys teiginiai. Visų respondentų atsakymus būtų galima klasifikuoti pagal pagrindines žmogaus poreikių grupes - fiziologinius, socializacijos ir dvasinius poreikius. Tačiau platesnei analizei reikètų daugiau i žmonių poreikius orientuoto klausimyno, kuris nebuvo šio tyrimo pagrindinis tikslas. Respondentų pateikti atsakymai patvirtina, kad kraštovaizdžio architektūros objekto vaidmuo yra svarbus trimis pagrindiniais aspektais. Pirma, jis suburia bendruomenès narius; antra dèl ekonominès naudos tikimybės; trečia - dèl dvasinès rekreacijos galimybių. Kaip respondentų atsakymai pasiskirsto pagal visuomenès poreikių grupes, pateikiama B priedo B3 lentelëje.

Antrasis apklausos etapas vyko $2016 \mathrm{~m}$. rugsèjo pirmosiomis dienomis. Klausimai buvo tikslingai pateikti tyrimo specifikai aktualioms profesinems ekspertų grupèms: architektams/urbanistams ir kraštovaizdžio architektams. Palankiai susiklosčius aplinkybėms tas pats klausimynas buvo pateiktas kraštovaizdžio architektūros srityje dirbantiems užsienio specialistams. Iš viso buvo apklaustas 31 ekspertas iš Lietuvos ir užsienio šalių. Taikant Delphi metodą, ekspertų atsakymai buvo suskirstyti ị tris skirtingas grupes ir analizuojami palyginamuoju principu. Lietuvos architektų ir urbanistų ekspertų grupę sudaré 9 respondentai, dažniausiai besidarbuojantys abiejose srityse. Profesinės veiklos prasme vienodai dominuoja projektavimo ir pedagoginè sritys. Iš devynių archi- 
tektų ir urbanistų grupès respondentų septyni turi didesnę nei 20 metų darbo patirtị. Iš dešimties Lietuvos kraštovaizdžio architektūros ekspertų dalis užsiima ir architekto ar urbanisto veikla. Vienas respondentas turi miškininko profesiją. Daugiausia šios grupès respondentų dirba projektavimo srityje. Iš dešimties kraštovaizdžio architektų grupès respondentų pusè turi didesnę nei 20 metų darbo patirtị, trys respondentai - 10-15 metų, du - 5-10 metų darbo patirtị. Tarp 12 užsienio ekspertų iš Estijos, Latvijos, Rusijos, Švedijos, Suomijos ir Ispanijos dominuoja kraštovaizdžio architektai. Daugelis iš jų dirba pedagoginèje veikloje, pusè vykdo mokslinę veikla, penki dirba ir projektavimo srityje. Tarp kitų veiklų yra ir doktorantūros studijos. Iš 12 užsienio ekspertų grupès pusè turi didesnę nei 20 metų, trys - 10-15 metų darbo patirti. Klausimynas, lyginant su pirmojo etapo anketa, buvo šiek tiek modifikuotas, atsižvelgiant ị pirmuoju atveju iškilusius teiginių netikslumus ir atsižvelgiant ị bendro tyrimo poreikius. Šis klausimynas buvo skirtas tik profesionaliai auditorijai. Kai kurie respondentai buvo tie patys, tačiau didžiają dali sudarė nauji žmonès. Klausimai buvo pateikti ir atsakymai gauti elektroniniu būdu.

Pirmas klausimas buvo apie tai, kokie miesto struktūros elementai lemia jo estetinę raišką, vaizdingumą (B priedas, B4 pav.). Lietuvos architektai ir kraštovaizdžio architektai išskiria tą pati pirmajji trejetuką, kuriame vienodai pirmają vietą užima reljefas, antrają - erdvès, trečiąją - pastatai. İdomu tai, kad visų kitų elementų reikšmè įvardijama beveik vienodai. Tik architektai želdinių masyvus vertina vienu balu aukščiau negu vandens telkinius. Užsienio ekspertai pirmajame trejetuke pirmiausia mato želdinių masyvus, o vẻliau - pastatus ir erdves. Lietuvos kraštovaizdžio architektai ir užsienio ekspertai vandens telkiniams skiria ketvirtą vietą. Visi vienodai mažiausiai vertina gatvių ir inžinerinių statinių įtaką miesto raiškai. Interpretuojant visų respondentų atsakymus, reikètų pabrèžti, kad Lietuvos ekspertų nuomonès yra pakankamai vieningos, ypač iškeliant reljefo reikšmingumą, matyt dẻl susiformavusių miesto suvokimo nuostatų, bendros profesinès praktikos, susiklosčiusios aplinkos. Atkreiptinas dèmesys, kad užsienio ekspertų požiūriu, reljefui suteikiamas tik labai vidutinis reikšmingumas. Tiesa, atskirų užsienio ekspertų nuomonė apie reljefo reikšmę varijavo nuo pirmos iki žemiausios vietos. Ši skirtinga Lietuvos ir užsienio ekspertų nuomonè dèl reljefo reikšmès aiškintina per profesinę savivoką. Užsienio kraštovaizdžio architektai dalyvauja dideliuose miesto pertvarkymo projektuose, kuriuose svarbią reikšmę turi jų projektuojamos želdinių kompozicijos, turinčios poveikị miesto estetinei raiškai, todèl jie ir skyrè pirmą vietą želdinių masyvams, reljefą traktuodami, kaip natūralų elementą.

Abiejuose apklausos etapuose visos Lietuvos ekspertu grupès svarbiausiu miesto struktūros elementu pasirinko reljefą. II etapo klausimas buvo papildytas reitinguojama samprata „erdvès“. Bendras prioritetinis miesto struktūros raišką lemiančių elementų sąrašas: reljefas; erdvès; pastatai; vandens telkiniai ir želdi- 
nių masyvai. Klausimas siekiant sužinoti ekspertų nuomonę, kokie elementai kuria gatvès estetini vaizdą, yra analogiškas pateiktam pirmajame apklausos etape. Visi respondentai pirmą vietą skiria pastatams, o antrą medžiams. Lietuvos architektai ir kraštovaizdžio architektai trečią vietą skiria meno kūriniams, o užsienio ekspertai - baldams ir ịrenginiams. Architektai ketvirtą vietą skiria gèlynams, o kraštovaizdžio architektai - baldams ir įrenginiams (B priedas, B5 pav.).

Tiek Lietuvos, tiek užsienio kraštovaizdžio architektai gėlynams skiria tiktai penktą vietą. Beveik visi vienodai žemai vertina reklamos vaidmeni gatvès estetikai. Ekspertai šia tema pateikè keletą savo komentaru, teikdami kad reklama dažniausiai daro neigiamą ịtaką estetiniam gatvès vaizdui, o gèlynai vaizdą įtakoja teigiamai tik sezono metu. Kraštovaizdžio architektūros ekspertẻ teigia, kad medžių ar gèlynų poveikio stiprumas priklausys jų parametrų santykio su gatvès ir pastatų parametrais. Urbanistikos ekspertè pabrèžia, kad medžio vaidmuo gatvèje priklauso nuo gatvès tipo, nes ,medis yra gan stambus elementas ir ne kiekvienai gatvei jis tinkamas, pvz., siaurose senamiesčių gatvelèse atsiradę medžiai tiesiog sunaikintų tą humanišką ir mažo mastelio erdvę“".

Lyginant su pirmuoju etapu, nuomonès dèl pastatų ir medžių svarbos kuriant gatvès erdvinị estetinị vaizdą visiškai sutampa. Pirmajame etape buvo geriau ịvertinta gèlynų svarba, kurią antrame etape pakeitè nuomonè dèl meno kūrinių svarbos. Bet kokiu atveju pagrindiniais struktūiniais elementais laikomi pastatai ir medžiai. Bendras pirmas gatvès estetinị vaizdą kuriančių elementų ketvertukas: pastatai; medžiai; meno kūriniai; gèlynai.

Antrojo etapo klausimyne buvo pateiktas aktualus kiekybini santyki aptariantis klausimas, kokie kiekybiniai kraštovaizdžio architektūros objekto parametrai yra svarbūs jo poveikiui (B priedas, B6 pav.). Reitingavimui buvo pateikta keletas pozicijų, kurios yra reglamentuojamos ịstatymuose, pavyzdžiui želdyno plotas, tenkantis vienam gyventojui, arba atstumai nuo želdyno. Visi ekspertai pripažįsta, kad svarbiausias yra gamtinių kompozicinių elementų skaičius kraštovaizdžio architektūros objekte. Pripažistama, kad aplinkos kokybė priklauso nuo profesionalaus jos sukomponavimo. Pagal architektus ir užsienio ekspertus kraštovaizdžio architektūros objekto užimamas ploto santykis su užstatytos teritorijos plotu yra tiek pat svarbus, o kraštovaizdžio architektai skiria jam antrą vietą. Šis adekvataus dydžio parametras yra susijęs ne tik su kiekybiniu vertinimu, nuo jo priklauso ir proporcijos klausimai, erdvinio santykio harmonija ir pan. Ekspertai trečioje vietoje pagal svarbą mato atstumo klausimą. İdomu tai, kad, visų respondentų manymu, mažiausiai svarbus yra kraštovaizdžio architektūros objekto plotas, tenkantis vienam kvartalo gyventojui. Vienas iš urbanistikos ekspertų papildomai pastebi, kad kiekybinis parametras „kraštovaizdžio architektūros objekto užimamas plotas santykyje su užstatytos teritorijos plotu“, nėra labai aiškus, nes ,vienaip gal atrodytų tas pats santykis, kai kalbame apie kvartalą, kitaip - kai kalbame apie miestą". Jis taip pat atkreipia 
dėmesị, kad teiginys ,gamtinių kompozicinių elementų skaičius kraštovaizdžio architektūros objekte" nèra labai aiškus. Interpretuojant nuomones galima teigti, kad svarbiausia yra tai, kad aplinka būtų formuojama ịvairiomis gamtinèmis ir kompozicinèmis priemonèmis ir kad žaliosios erdvès santykyje su pastatais būtų harmoningo ir adekvataus dydžio. Matyt, igyvendinus pirmuosius principus, atstumas ir plotas vienam gyventojui atrodo nebe toks reikšmingas.

Apklausoje buvo pateiktas klausimas, kuriuose miesto kompozicijos komponentuose kraštovaizdžio architektūros elementai yra svarbesni nei urbanistiniai (B priedas, B7 pav.). Šiuo klausimu siekta išprovokuoti respondentus tam tikrai diskusijai su pačiu savimi, permąstant galimas miesto komponavimo alternatyvas, prioritetą suteikiant kraštovaizdžio principams. Architektai ir kraštovaizdžio architektai ị pirmą trejetuką išskiria šiuos miesto kompozicijos komponentus - panoramas, daugiaplanes perspektyvas ir miesto siluetą. Lietuvos kraštovaizdžio architektai visiškai nemato savo profesinio vaidmens sprendžiant užstatymo išklotinių ir užstatymo dominančių klausimus. Architektai kraštovaizdžio architektūros elementų reikšmingumą užstatymo išklotinèse mato pagal svarbą ketvirtoje vietoje. Architektai mato palyginus mažą kraštovaizdžio architektūros elementų vaidmenị kuriant erdves. Užsienio ekspertai, priešingai, pirmą vietą skyrẻ atviroms erdvėms, o antroje vietoje pagal svarbą išskyrė daugiaplanes perspektyvas. Bendras prioritetinis ketvertukas: daugiaplanès perspektyvos; panoramos; miesto siluetas; atviros erdvès.

Reaguodami ị pateiktą klausimą urbanistikos ekspertai išsake ir vertų aptarimo pastebejjimų. Vienas ir iš jų teigia, kad klausimas, kuriuose miesto kompozicijos komponentuose kraštovaizdžio architektūros elementai svarbesni nei urbanistiniai, yra nekorektiškas. Taip pat gauta pasiūlymų dẻl pačios klausimo struktūros - siūloma klausti, kurie yra vienodai svarbūs, ir pateikti poromis: panoramos - svarbus reljefas ir užstatymas, miesto siluetas - svarbūs gamtiniai elementai ir užstatymas, daugiaplanès perspektyvos - svarbūs gamtiniai elementai ir užstatymas. Taip pat išreikšta nuomonè, kad ,pats gyvų gamtos darinių buvimas aplinkoje kuria emocini efektą ir kad svarbi kompozicinè priemonė yra „statinių ir gamtinių elementų mastelio harmonija“.

Klausimu, kokie kraštovaizdžio architektūros objekto ir urbanistinio konteksto sąveikos faktoriai kuria emocinį efektą, norèta sužinoti, kokios emocinio poveikio galimybès atsiranda naudojant kraštovaizdžio architektūros priemones ir principus (B priedas, B8 pav.). Šis aspektas yra svarbus dẻl to, kad emocinio poveikio rezultatas rodo kraštovaizdžio architektūros ir urbanistikos sąveikos estetini potencialą. Visi ekspertai i pirmą trejetuką ịtraukè du vienodus faktorius - „kontrastas tarp gyvosios gamtos ir statinių“ ir ",atvirų ir uždarų erdvių kaita“", suteikdami jiems pirmą, antrą arba trečią vietas. Architektai ir kraštovaizdžio architektai i pirmą trejetuką išskyrè ir vaizdų kaitos dinamiką. Užsienio ekspertai antrą vietą skyrė garsams ir kvapams. Lietuvos kraštovaizdžio archi- 
tektai labai žemai vertina spalvų bei šviesos ir šešèlių emocinị poveikị, tuo tarpu užsienio ekspertai tiems patiems faktoriams skiria vidurinę vietą. Kraštovaizdžio eksperte iš Švedijos pastebi, kad kraštovaizdžiui yra labai svarbus pastatų aukščio ir atstumo tarp jų santykis. Ji atkreipia dèmesį, kad emocinị efektą kuria ne tik atspindžiai vandenyje, bet ir „,vandens garsai“. Toje pačioje temoje ji priduria, kad svarbu yra atviros vietos arba, kitaip tariant, erdvès tiek mieste tiek parke įveiklinimas. Lietuvos urbanistikos eksperte pabrēžia dermès tarp gamtinių ir antropogeninių elementų svarbą. Bendras pirmasis emocinio efekto faktorių trejetukas: kontrastas tarp gyvosios gamtos ir statinių; atvirų ir uždarų erdvių kaita; vaizdų kaitos dinamika.

Harmonijos siekị suprantant kaip vieną iš svarbiausių mieste vykstančių procesų sąveikos tikslų, buvo norima sužinoti ekspertų nuomonę, kokios kompozicinès priemonès kuria harmoniją tarp kraštovaizdžio architektūros objekto ir urbanistinio konteksto (B priedas, B9 pav.). Visi ekspertai pirmajame trejetuke mato kompozicijos darną. Architektai ir kraštovaizdžio architektai pirmą vietą skiria funkciniam ir estetiniam susietumui, užsienio ekspertai - proporcijoms. Kraštovaizdžio architektai proporcijoms skiria antrą vietą. Lietuvos urbanistikos ekspertė papildo, kad harmoniją lemia „sprendinio integralumas“. Beje, faktorius ,sprendinių integralumas“ yra ir svarbus sąveikos tvarumo rodiklis. Bendras pirmasis harmonijos kompozicinių priemonių ketvertukas: kompozicijos darna; funkcinis ir estetinis susietumas; proporcijos; stiliaus vientisumas.

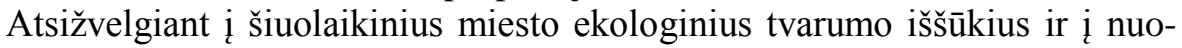
monę, kad kraštovaizdžio architektūra gali būti tarpininke sprendžiant ekologines ir miesto vystymo problemas, ekspertams buvo pateiktas klausimas, kokie kraštovaizdžio architektūros objekto ir urbanistinio konteksto sąveikos bruožai laikytini tvariais (B priedas, B10 pav.). Lietuvos ir užsienio kraštovaizdžio architektai pirmą vietą skiria tvariems vandentvarkos sprendiniams. Tuo tarpu architektai tvariems vandentvarkos sprendiniams, kaip ir racionalumui, skiria tik trečią vietą pagal svarbą. Architektai pirmą vietą duoda regionalumui ir vietinių augalų ir natūralių medžiagų panaudojimui. Visi likę ekspertai taip pat išskiria vietinių augalų ir natūralių medžiagų panaudojimą, suteikdami jiems antrą vietą. Abiejų grupių Lietuvos ekspertai antrą vietą skiria kompleksiškumui, o užsienio ekspertai tam skiria mažiausiai dèmesio. Šis skirtumas galètų būti aiškinamas to paties žodžio „kompleksiškumas“ ir angliško atitikmens complexity skirtingu turinio suvokimu. Mūsų suvokimu, ,kompleksiškumas“ daugeliu atvejų suprantamas kaip sprendinių ar funkcijų tarpusavio derinimas, artimas sąvokai ,integralumas". Anglakalbeje visuomeneje complexity daugiau suprantamas kaip sudètingumas - sprendinių ar funkcijų ịvairovè. Upsalos (Śvedija) universiteto doktorantė papildo tvarios sąveikos rodiklių sąrašą - „,̌monių dalyvavimas“ (angl. human involvement); „miesto ekosistemu atnaujinimas“ (angl. restoration of urban ecosystem). Tartu (Estija) universiteto atstovas siūlo sąveikos tvarumo 
rodiklị - „atsparumas“ (angl. robustness). Sociologè iš Švedijos, atsakydama ị klausimą, kokia sąveika būtų laikoma tvaria, ji papildo dar keliais veiksniais: „tvarus atliekų tvarkymas"; ,lanksti ir tvari miesto planavimo ideologija“; ,tvarios medžiagos pastatuose ir kituose miesto i̇renginiuose". Galiausiai švedų atstové pastebi, kad anketos tema labai įdomi, bet ị kai kuriuos klausimus sunkoka atsakyti. Bendras pirmasis tvarumo bruožų ketvertukas: vietinių augalų ir natūralių medžiagų panaudojimas; tvarūs vandentvarkos sprendiniai; regionalumas; kompleksiškumas.

Trečias ekspertų apklausos etapas vyko 2018 m. vasario mėn. ir apėmė kraštovaizdžio architektūros bei urbanistikos ir architektūros ekspertus iš Lietuvos. Ekspertams Delphi metodo principu buvo suformuluoti tyrimui reikalingi klausimai. I kausimus atsake 9 kraštovaizdžio architektūros srities ekspertai ir 6 architektai arba urbanistai. Tiek vienos, tiek kitos grupès narių profesinė veikla apima projektavimą, viešaji administravimą, mokslinę ir pedagoginę veiklą. Tarp kraštovaizdžio architektų grupès respondentų daugiausia dirbančių projektavimo srityje, o tarp apklausoje dalyvavusių architektų ir urbanistų - daugiausia mokslinejje ir pedagoginèje srityje. Anketoje, be bendrujų klausimų, buvo pateikti 8 struktūruoti profesiniai klausimai.

Pirmųjų dviejų apklausos etapų rezultatai parodè, kad respondentai miesto raišką (tiek miesto mastu, tiek kvartalo ir gatvės požiūriu) lemiantiems fizinès struktūros elementams pirmiausia priskiria reljefą, pastatus, erdves, vandens telkinius ir želdinius (atitinkamai pavienius medžius arba jų masyvus). Šie rezultatai paskatino trečiajame etape formuluoti klausimus sugretinant poromis gamtinių ir urbanistinių struktūrų elementus, kurie ankstesnèse apklausose buvo išskirti kaip svarbūs miesto raiškos, o tuo pačiu ir kraštovaizdžio, formantai.

Kryžminių klausimų esmè - sužinoti ekspertų nuomonę dẻl pirmiau išvardintų miesto struktūrinių elementų sąveikos ilgaamžiškumo, trapumo bei reikšmingumo kuriant miestą (B priedas, B11 pav.). İ klausimą, kurių kraštovaizdžio formantų sąveika atrodo stabiliausia laiko tékmèje, daugiausia balų abiejose ekspertų grupèse surinko reljefo ir vandens bei reljefo ir erdvès sąveika. Mažiausiai - pastatų ir želdinių bei želdinių ir gatvių sąveikos.

Kitu klausimu buvo norèta sužinoti ekspertų nuomonę, kurių kraštovaizdžio elementų sąveika yra jautriausia (greičiausiai kintanti) urbanistiniuose procesuose (B priedas, B12 pav.). Kraštovaizdžio architektų manymu, jautriausia sąveika yra tarp želdinių ir gatvès bei želdinių ir erdvés, o mažiausiai jautri tarp pastatų ir reljefo bei pastatu ir gatvès. Architektai ir urbanistai mano, kad jautriausia sąveika yra tarp pastatų ir reljefo, o mažiausiai jautri - tarp reljefo ir vandens telkinių bei erdvių ir vandens telkinių. Kaip matome, kardinaliai išsiskiria nuomonès dèl pastatų ir reljefo sąveikos jautrumo.

Apibendrinant pirmụjų dviejų klausimų atsakymų rezultatus išryškëja, kad stabiliausia laikoma sąveika tarp reljefo ir vandens telkinių bei tarp reljefo ir 
erdvès. Tai atliepia pirmais etapais gautus atsakymus, kuriuose reljefas ir vandens telkiniai bei erdvès laikomi vienais iš svarbiausių miesto raiškos formantų. Šios sąveikos stabilumas lemia miesto identiteto stabilumą, todèl bet kokie veiksmai, iš esmès griaunantys nusistovejjusią sąveiką tarp minètų elementų, turètų būti eliminuojami. Kita vertus, tam tikrais atvejais šios sąveikos galima siekti kuriant laiko tẻkmèje ilgai išliekančias reljefo, vandens telkinių ir erdvių kompozicijas. Nors ekspertų nuomonès dèl jautriausios sąveikos išsiskyrè, galima pastebėti, kad želdinių pozicija urbanistiniuose procesuose yra gana trapi, nes, kaip rodo praktika, jie poreikiui esant yra pašalinami. Sąveika tarp želdinių ir kitų objektų kinta želdiniams augant, keičiantis tarpusavio santykiui ir proporcijoms. Architektų nuomonė dẻl sąveikos tarp pastatų ir reljefo jautrumo tikriausiai yra pagrissta profesine praktika, kai statybų metu yra stipriai keičiamas reljefas arba atsirandantys nauji pastatai keičia nusistovejusi vizualini santyki tarp pastatų ir reljefo. Tam tikrų elementų sąveikos jautrumas interpretuotinas dvejopai. Pirma - kaip neišvengiamybè, kai nustatant prioritetus dèl teritorijos vertybių išsaugojimo arba kūrybiniame procese numatomi ir koordinuojami sąveikos pokyčiai. Antra - kai suvokiant sąveikos trapumą siekiama maksimaliai ją išsaugoti.

Atsižvelgiant $\mathfrak{i}$ tai, kad pradedant kurti kvartalą reikalinga nusistatyti kriterijus ir pasirinkti prioritetus, ekspertams buvo pateiktas klausimas, kurių kompozicinių elementų sąveikos aspektai jiems atrodytų svarbiausi pradedant kurti kvartalą (B priedas, B13 pav.). Architektai ir urbanistai, ị pirmą vietą iškeldami miesto kvartalo struktūrai esminius reljefo, vandens ir erdvių sąveikos aspektus, demonstruoja miesto suvokimo per kraštovaizdį principus. Apibendrinti šio klausimo rezultatai pateikiami 2.1 lentelèje.

2.1 lentelė. Miesto gamtinių ir antropogeninių struktūrinių elementų sąveikos ekspertinio vertinimo rezultatai. Šaltinis: V. Deveikienè, 2018

Table 2.1. The results of an expert assessment of the interaction of natural and anthropogenic structural elements of the city. Source: V. Deveikiené, 2018

\begin{tabular}{|l|l|l|}
\hline Stabiliausia sąveika laike & $\begin{array}{c}\text { Jautriausia sąveika urba- } \\
\text { nistiniame procese }\end{array}$ & $\begin{array}{l}\text { Svarbiausi sąveikos aspek- } \\
\text { tai pradedant kurti kvartalą }\end{array}$ \\
\hline $\begin{array}{l}\text { Reljefas - vandens telki- } \\
\text { niai }\end{array}$ & Želdiniai - gatvès & Reljefas - erdvès \\
Reljefas - erdvės & Želdiniai - erdvès & Reljefas - vandens telki- \\
Pastatai - reljefas & Pastatai - reljefas & niai \\
Erdvès - vandens telkiniai & Erdvès - pastatai & Erdvès - vandens telkiniai \\
& Reljefas - erdvès & Erdvès - pastatai \\
\hline
\end{tabular}

Ekspertų apklausos rezultatai parodè, kad miesto raišką lemiantys, o tuo pačiu ir aktyviausi sąveikos komponentai yra reljefas, vandens telkiniai, erdvès, 
pastatai, želdiniai ir gatvės. Šių gamtinių ir antropogeninių komponentų tarpusavio sąveikos vertinimas atskleidè jos stabilumo, jautrumo ir prioritetų aspektus. Būtent šie gamtiniai ir antropogeniniai miesto struktūriniai elementai buvo pasirenkami tolimesniam eksperimentinio tyrimo etapui.

Atsižvelgiant ị tvaraus miesto pagrindinius vertinimo aspektus, norèta sužinoti ekspertų nuomonę dèl ekologinio, socialinio ir estetinio prioritetų suderinimo svarbos (B priedas, B14 pav.). Abi respondentų grupés mano, kad projektuojant kvartalą svarbiausia yra suderinti visus tris - ekologinį, estetini ir sociofunkcinį aspektus. Architektai ir urbanistai gerokai mažiau balų skiria estetinio ir sociofunkcinio aspektų sąveikai, ją palikdami pagal svarbą paskutinèje vietoje. Respondentų vieningas atsakymas patvirtina svarbą teritorijas integraliai ir kompleksiškai nagrinèti visais trimis aspektais ir siekti, kad jų sąveikos būtų siekiama tvarkant miesto teritorijas. Buvo aktualu sužinoti ekspertų nuomonę, kokias estetinio poveikio kompozicines priemones jie priskirtų kraštovaizdžio architektūros kūrybos priemonèms (B priedas, B15 pav.). Kraštovaizdžio architektai lygiaverčiai prioritetinėms kraštovaizdžio architektūros priemonėms priskiria šviesos, spalvų ir formų kaitą laike bei atvirų ir uždarų erdvių kaitą. Kaip svarbiausias derètų išskirti keturias pagrindines priemones - šviesos, spalvų ir formų kaita laike; atvirų ir uždarų erdvių kaita; daugiaplanės perspektyvos; horizonto linijos ir jos kaitos efektų sukūrimas.Ekspertai taip pat buvo klausiami, kurie teritorijos analizès ir projektavimo principai yra specifiniai kraštovaizdžio architektūros sričiai (B priedas, B16 pav.).

Apibendrinant ekspertų nuomones, pagrindiniai, kraštovaizdžio architektūros sričiai priskiriami teritorijos analizės ir projektavimo principai yra: daugiasluoksnè sisteminé teritorijos analizé; gamtinių ir antropogeninių procesų analizé ir kūrimas; atvirų erdvių nuoseklios sekos nustatymas ir kūrimas. Siekiant sužinoti, kaip kraštovaizdžio architektūros vaidmenị ekspertai vertina tvaraus miesto problematikos kontekste, buvo klausiama, kuriuose tvaraus miesto procesuose kraštovaizdžio architektūros kūrybinès priemonès ir principai yra svarbiausi (B priedas, B17 pav.). Ekspertų nuomone, kraštovaizdžio architektūros kūrybinés priemonès ir principai svarbiausi yra šiuose tvaraus miesto procesuose: gamtinių išteklių taupymas ir panaudojimas; prioritetų nustatymas vertinant esamą situaciją; degradavusių teritorijų atkūrimas; tvari vandentvarka. Šie atsakymai sutampa su II apklausos etape tuo pačiu aspektu išsakyta ekspertų nuomone.

Siekiant sužinoti ekspertų nuomonę dèl kraštovaizdžio architektūros vaidmens sprendžiant socialinès reikšmès miesto tvarkymo problemas, buvo klausiama, kuriems aplinkos kokybès iššūkiams ir problemoms spręsti labiausiai tinka kraštovaizdžio architektūros kūrybos principai ir priemonès (B priedas, B18 pav.). Apibendrinant ekspertų vertinimus, kraštovaizdžio architektūros principų ir priemonių vaidmuo svarbiausias šioje aplinkos kokybės gerinimo problematikoje: sąlygos fizinei ir dvasinei rekreacijai; sveika aplinka; vietos 
identitetas; aplinkos humanizavimas. II ir III etapu apklausos buvo nukreiptos i kraštovaizdžio architektūros ir urbanistikos sprendinių kokybinès sąveikos analizę, siekiant išsiaiškinti, kokius būdingus šios sąveikos bruožus mato ekspertai ir koki vaidmeni šioje sąveikoje jie priskiria kraštovaizdžio architektūros principams ir priemonèms. Apibendrinti ekspertų nuomonių rezultatai pateikiami 2.2 lentelèje.

2.2 lentelè. Kraštovaizdžio architektūros ir urbanistikos sprendinių sąveikos bruožų ir ekspertinio vertinimo rezultatai. Šaltinis: V. Deveikienè, 2018

Table 2.2. The features of interaction between landscape architecture and urban solutions and the results of expert assessment. Source: V. Deveikienè, 2018

\begin{tabular}{|l|l|l|l|}
\hline \multicolumn{4}{|c|}{ Kraštovaizdžio architektūros ir urbanistinių sprendinių sąveikos bruožai } \\
(I-II apklausos etapas)
\end{tabular}

Tyrimas parodè, kad ekspertų išskirti prioritetiniai kraštovaizdžio architektūros principai ir priemonès yra adekvatūs išskirtiems svarbiausiems kraštovaizdžio architektūros ir urbanistikos sprendinių sąveikos bruožams. Iš to darytina išvada, kad kraštovaizdžio architektūros priemonès galètų būti aktyviau taiko- 
mos gamtinių ir antropogeninių miesto struktūros elementų sąveikos optimizavimo procese. Kraštovaizdžio architektūros objektui visos respondentų grupės vienareikšmiškai priskiria želdynų sistemą, kas rodo kraštovaizdžio architektūros svarbą ịvairiuose miesto kūrimo lygmenyse. Visų respondentų nuomone, svarbiausia kraštovaizdžio architektūros objekto reikšmè yra ta, kad jis harmonizuoja aplinką su pastatais, o tai glaudžiai susiję su gyvenimo kokybe.

Ekspertu apklausos rezultatai rodo, kad tokie teritorijos analizès ir projektavimo principai, kaip daugiasluoksnè sisteminè teritorijos analizé, gamtinių ir antropogeninių procesų analizė ir kūrimas, atvirų erdvių nuoseklios sekos nustatymas ir kūrimas, yra priskiriami kraštovaizdžio architektūros sričiai. Respondentų pateikti kraštovaizdžio architektūros socialinio vaidmens aprašymai atskleidžia, kad jis yra svarbus trim pagrindiniais aspektais: suburia bendruomenès narius; kuria ekonominę naudą; teikia dvasinès rekreacijos naudą. Kraštovaizdžio architektūros principai ir kūrybinès priemonès visų respondentų pripažįstami svarbiausiais šiuose tvaraus miesto procesuose: gamtinių išteklių taupymas ir panaudojimas; prioritetų nustatymas vertinant esamą situaciją; degradavusių teritorijų atkūrimas; tvari vandentvarka. Bendri apklausos rezultatai patvirtino prielaidą, kad kraštovaizdžio architektūros ir urbanistikos sprendinių sąveika turètų būti nagrinejjama tvarumo paradigmos šviesoje, derinant tarpusavyje ekologinius, socialinius ir estetinius prioritetus ir kriterijus.

Atliekant trijų (arba daugiau) etapų apklausos rezultatų palyginamają analizę, tikètina, kad jos metu išgryninama pakankamai objektyvi ekspertų nuomonè. Šiame kraštovaizdžio architektūros raiškos mieste tyrime pasiteisino pasirinktas tikslinių grupių apklausos variantas, nes buvo galimybè palyginti ịvairių miesto kūrimo proceso dalyvių nuomones, kurių sutapimai ir skirtumai išprovokavo gilesnes įžvalgas ir platesnius apibendrinimus. Kraštovaizdžio architektų ir urbanistų atsakymai sugula logiška klausimyno užduota seka ir praktiškai nepateikia jokių alogizmų. Abiejų profesijų ekspertų nuomonès daugiausiai sutampa, o tai liudija teiginiu patikimumą, bendrą požiūrị ị miesto planavimo ir projektavimo prioritetus bei perspektyvas tolimesniam bendradarbiavimui.

\subsection{Kraštovaizdžio architektūros ir urbanistikos sprendinių sąveikos tyrimo modelio sudarymas}

\subsubsection{Gamtinių ir antropogeninių struktūrų sąveikos aktualizavimas}

Visi urbanistiniai procesai vyksta kraštovaizdžio kontekste ir yra neišvengiamai susiję su gamtiniu pagrindu. Kiekvienas igyvendintas urbanistinis sprendinys keičia kraštovaizdyje nusistovejusius gamtinius bei socialinius procesus. Todèl 
miesto gaivinimo ir vystymo klausimai turi būti analizuojami ir sprendžiami per kraštovaizdžio prizmę bei gamtinių ir antropogeninių procesų sąveiką. Miesto raišką lemia esamos gamtinès ir žmogaus sukurtos urbanistinès struktūros. Kraštovaizdžio architektūra pagal savo kompetencijas sprendžia miesto, kvartalo ar objekto dermès su gamtine aplinka klausimus, todèl kiekvienas urbanistinis ar architektūrinis reiškinys, susijęs su gamtiniu pagrindu ar atskirais gamtiniais elementais, yra potencialus kraštovaizdžio architektūros kūrybinès veiklos objektas.

Rekreacinių kompleksų kūrimo gamtinèje aplinkoje nuostatas yra apžvelgę E. Staniūnas ir G. Stauskis (2011) išskiria pagrindinius natūralaus kraštovaizdžio sistemos elementus - žemès paviršiaus reljefą, augmeniją, vandens telkinius. Reljefo šlaitų savybè atverti tolimus vaizdus turi būti pastebima ir eksploatuojama ịrengiant regyklas, apžvalgos taškus. Želdinių išorinès ir bioekologinès savybès yra svarbios tiek estetiniu emociniu, tiek socialiu, tiek ekologiniu aspektu. Urbanistiniu požiūriu želdiniai atlieka labai svarbų vietovès ekologinio stabilizatoriaus vaidmenį. Keturi žemès paviršiaus formos elementai laikytini svarbiausiais kraštovaizdžio architektūroje ir urbanistikoje, tai: 1) vandens telkinio kranto linija, 2) slènio briauna, 3) plynaukšte (arba terasos plokštuma), 4) vandenskyros linija, t. y. linija, jungianti aukščiausius vietovès taškus (Staniūnas ir Stauskis 2011). Nuo šių elementų priklauso estetinè vietovės interpretacija ir urbanistinių bei architektūrinių sprendinių galimybès. P. Grecevičius teigia, kad kraštovaizdžio architektas erdves kuria taip pat kaip ir architektas ar urbanistas, tačiau prioritetiškai naudoja sudetingesnius struktūrinius erdvių komponentus: teritorijos (vietos) reljefą, augalus, vandenį ir kitus gamtinius elementus (Grecevičius et al. 2013).

Kaip parodė ekspertų apklausos daugiapakopė analizè, svarbiu miesto raiškos pagrindu visi ekspertai pripažista pagrindinius gamtinius elementus - reljefą, vandens telkinius ir želdinius. Ekspertų nuomone, šių gamtinių miesto struktūros elementų sąveika su antropogeninès kilmès miesto elementais - pastatais, erdvėmis ir gatvėmis - lemia aplinkos kokybę. Šie trys pagrindiniai gamtiniai elementai ir buvo analizuojami santykyje su urbanistinèmis struktūromis. Sąveikos analizei buvo adaptuoti miesto struktūros suvokimo elementai - takai (angl. paths), mazgai (angl. nodes), ribos (angl. edges), vietoženkliai (angl. landmarks), kvartalai (angl. districts), kurie vis dažniau pritaikomi kraštovaizdžio architektūros tyrimuose (Bchir Jaber 2013). Šie miesto suvokimo elementai pasirinkti tyrimui dèl to, kad jie gerai atspindi charakteringas gamtinių ir antropogeninių struktūrų sąveikos apraiškos vietas, leidžia sistemingai ir integraliai pažvelgti ị analizuojamos teritorijos urbanistinị audinị.

Žmogus erdvę suvokia ir pažịsta įvairiais pojūčiais ir potyriais. Teigiama, kad erdvès suvokimas yra ịgimtas, o nustatyti padètị erdvèje ir erdvę pažinti išmokstama. Erdvès suvokimui turi įtakos religiniai, politiniai, kultūriniai kiek- 
vienos epochos ir bendruomenès kriterijai (Araucho 1982; Grecevičius et al. 2013). Architektūrinès erdvès formos ịvaldymo procesas yra sudètingas ir daugianaris, susiejantis judejjimo ir patogaus buvimo architektūrinèje erdvejje funkcijas. Erdvès gyvybinę schemą charakterizuoja trys pagrindiniai kriterijai: a) traukos zonos arba taškai; b) erdvès centras; c) konfliktiniai mazgai (nemalonios vietos). Visa tai nusako erdvès kokybę, kurios vertinimas iš esmès yra subjektyvus (Grecevičius et al. 2013). Miesto struktūros analitikas K. Lynch padaré išvadą, kad „svarbus miesto planavimo uždavinys - normuoti informaciją erdvèje ir laike" (Lynch 1960) - tai aktualu ir kraštovaizdžio architektūroje. Tiesi linija - tai vienas žvilgsnis, iškart suvokta perspektyva, viena informacija, o kreiva trasa (gatvė, parko takas ir pan.) - tai ištisas procesas su daugybe perspektyvų ir scenų (Grecevičius et al. 2013). Pasak mokslininkų, tyrinejjančių urbanistinio kraštovaizdžio problemas, fenomenologinis principas parodè, kad žmogus susidaro menamą miesto vaizdą, susidedantị iš tam tikrų ryškiausių jo požymių, ịsimenančių atmintyje ir leidžiančių identifikuoti patị objektą ar tam tikras jo dalis, ir todèl galima teigti, kad toks formuluojamo vaizdinio turinys kartu apibūdina ir tam tikrus miesto savitumus (Dringelis et al. 2015). P. Kavaliauskas teigia, kad kadaise K. Lynch išgryninti pateikti elementai gali būti panaudoti sociotopo fizinès struktūros modelyje, tačiau pabrežtina, jog šie elementai pirmiausiai tinkami urbanizuotos aplinkos semantinei analizei (Kavaliauskas 2014). Latvių mokslininkè Maija Jankevica teritoriją vertindama estetiniu ir ekologiniu aspektais bandė taikyti K. Lynch percepcinị miesto analizès metodą išskirdama penkis kompozicinius elementus. Bet vėliau šio metodo buvo atsisakyta, nes, mokslininkès manymu, jis yra netinkamas vertinant ekologiniu aspektu ir naudotinas tik žmogaus sukurtoje aplinkoje (Jankevica 2012).

Gamtinių ir urbanistinių struktūrų sąveiką nagrinëjant kraštovaizdžio architektūros požiūriu visi penki elementai (takai, mazgai, ribos, vietoženkliai ir kvartalai) yra svarbūs, bet ypač išskirti reikètu ribas, takus ir mazgus. Ribos yra linijiniai elementai, stebejjimo takų nesudarančios, tačiau skirtingo pobūdžio arealus skiriančios linijos (Kavaliauskas 2014). Tai gali būti ịvairaus tipo ir kilmès besitęsiantys linijiniai lūžiai - krantai, geležinkelio atkarpos, užstatymo ribos, sienos, miško pakraščiai ir t. t. Šios ribos gali būti barjerai, daugiau ar mažiau praeinami, uždarantys vieną teritoriją nuo kitos, arba jos gali būti „,siūlès“, išilgai kurios skirtingos teritorijos siejasi ir jungiasi viena su kita. Riba daugeliui žmonių yra svarbus organizuojančių savybių turintis kompozicinis elementas, atliekantis prieigų, laukimo ir susitikimo vietos identifikavimo vaidmeni. Ribą gali sudaryti tiek pastatytos, tiek gamtinès struktūros. Vandens telkiniai, šlaitai urbanizuotoje teritorijoje sudaro svarbius miesto vaizdo elementus - ribas (Lynch 1960; Dringelis 2015). Miško ar kitų želdinių masyvai sukuria ryškias gamtinio pobūdžio ribas, kurių išraišką lemia žaliujų masyvų sudètis, reljefas ir žmogaus sukurta kompozicija. Jeigu teritorijos riba labai monotoniška verta, paịvairinti 
abi ribos puses, kad stebėtojas būtų suorientuotas vidus-išorè kryptimis. Tai gali būti padaryta naudojant kontrastuojančias medžiagas arba želdinius. Norint padidinti ribos raiškumą rekomenduojama didinti prieinamumą ir panaudojimą. Pavyzdžiui, vandens pakrantes atverti judejjimui ir rekreacijai (Lynch 1960). Kraštovaizdžio architektūros požiūriu labai svarbu yra tai, kad ribos iš esmès formuoja erdvių kontūrus, suteikia joms planinę ir erdvinę formą.

Kitas svarbus tiek miesto gyvenimą, tiek kraštovaizdžio pažinimo kompozicinis elementas yra takai - jungtys arba judejjimo trajektorijos. Pasak K. Lynch, ,jungtys yra ilgi judejjimo kanalai, išilgai kurių stebètojai nuolat atsitiktinai ar potencialiai juda" (Lynch 1960). Tai gali būti gatvės, pėsčiujų takai, tranzitiniai keliai, vandens kanalai, geležinkeliai. Daugelio žmonių vaizduotèje tai yra vyraujantis (svarbiausias) elementas. Žmonès jais judėdami stebi miestą ir išilgai jungties išsidèsčiusius ir sąveikaujančius ịvairius aplinkos elementus. Stebètojams daro įspūdị, ypač išlieka atmintyje akivaizdžios „kinestatinės“ kelio (jungties) kokybinès savybės ir emocijos, kurios buvo patirtos judant ta trajektorija: posūkis, kilimas aukštyn, leidimasis žemyn. Šių kelio savybių pamatas yra vietovès topografija, bréžiamo kelio ir reljefo sąveika. Išilgai kelio esantys akcentai, erdvių kaita, įspūdžių dinamika gali būti suorganizuota kaip melodija, suvokta ir įsivaizduota per tam tikrą laiko intervalą (Lynch 1960).

Mazgai gali būti tiesiog žmonių srautų koncentracijos vietos, kurios įgauna svarbos dèl prisotinto (kondensuoto) fizinio panaudojimo pobūdžio, kaip gatvės kampą užbaigiantis skveras. Kai kurie koncentruoti mazgai yra centras ir pavyzdinè kvartalo arba rajono vieta, iš kurios sklinda jų ịtaka, jie yra vietovès simboliai. Tokie mazgai gali būti vadinami branduoliais. Mazgo idèja susijusi su jungties idëja. Keliaujančiojo įspūdžiai sustiprinami jungčiu sankirtose, kurios gali būti išvystytos iki savarankiškų mazgų. Tokiu principu yra formuojami miestų skverai, kraštovaizdžio architektūros ar kitų meninių priemonių pagalba stiprinant emocinị krūvị, paịvairinant keliautojo ịspūdžius. Mieste didesnès želdynų teritorijos gali sudaryti urbanistinès struktūros rajonus su ryškiomis tarpusavio ribomis, mažesnès - mazgais (Lynch 1960; Dringelis et al. 2015).

Gamtinių ir urbanistinių struktūros elementų sąveikos analizè pasirinkta kaip kraštovaizdžio architektūros ir urbanistikos sprendinių raiškos laukas. Teritorijoje esančių gamtinių ir antropogeninių elementų sąveika tiriama analizuojant sąveiką tarp kiekvieno iš elementų atskirai - reljefas, vanduo ir augalija analizuojami santykyje su ribomis, takais, mazgais, vietoženkliais ir kvartalo struktūromis (2.6 pav.). 


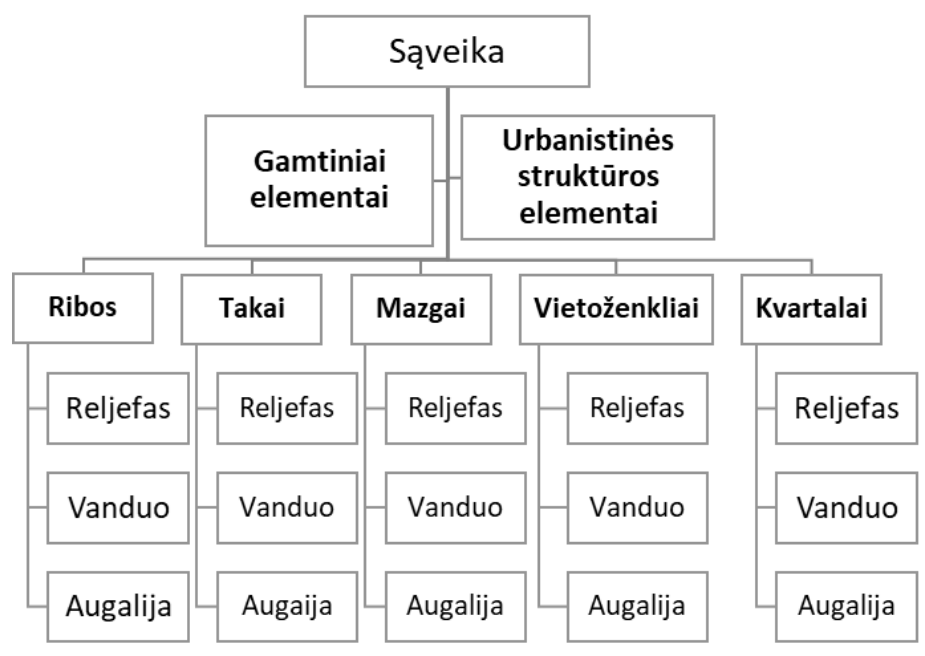

2.6 pav. Gamtinių ir urbanistinių struktūrų elementų sąveikos analizès schema.

Šltinis: V. Deveikienè, 2018

Fig. 2.6. The schema of the analysis of interaction between the elements of natural and urban structures. Source: V. Deveikienè, 2018

Bet kokie miesto planavimo ar projektavimo sprendiniai turi teorini sąlyti su gamta, o juos iggyvendinant šis sąlytis iggauna fizinę išraišką, kurios kokybe priklauso nuo projektinių (teorinių) sprendinių. Gamtinių procesų sąveika vyksta ne žmogaus reguliavimo sferoje ir gali daryti poveikị antropogeniniams procesams. Analogiškai, žmogaus kuriami procesai (taip pat ir urbanistiniai) daro poveikị gamtos procesams. Akivaizdus poveikio bet ne sąveikos pavyzdys būtų aktyvi urbanizacija, kai gamtiniai procesai yra pažeidžiami žmogaus veiksmų, jie sparčiai kinta, igauna kitas formas, nebūtinai palankias žmogui. Ir atvirkščiai - kai daugiau ar mažiau urbanizuota teritorija yra apleidžiama žmogaus, joje pradeda dominuoti nauji gamtiniai procesai, pakankamai sparčiai užgoždami urbanizacijos ženklus. Iš esmès gamtinių ir urbanistinių struktūrų sąveika yra lemiama žmogaus veiksmų ir nuo jų priklauso tos sąveikos rezultatai. Todèl yra labai svarbu, kad strateguojant, planuojant ir projektuojant urbanistinius procesus, būtų integraliai mąstoma apie gamtinius procesus ir jų sinergiją su urbanistiniais.

\subsubsection{Pagrindiniai optimalios sąveikos principai ir nuostatos}

Sąveika (angl. interaction) literatūroje yra aiškinama pasitelkiant ịvairias mokslo sritis - matematiką, fiziką, biologiją, sociologiją ir t. t. Tiriant sąveiką tarp kraštovaizdžio architektūros ir urbanistikos sprendinių aktualiausias būtų socialinių mokslų srities termino "sąveika“" aiškinimas, nes nagrinèjami objektai yra žmogaus veiklos rezultatai. Šių rezultatų naudojimas, pažinimas ir suvokimas yra 
žmonių, visuomenès interesų laukas. Pasak Prancūzijos mokslininkų psichologų Edmond Marc ir Dominique Picard, sąveika neturi vienintelio apibrēžimo, priešingai, ši sąvoka turi tam tikrą prasminę (semantinę) sklaidą: kartais ji apibrezžia procesus, kartais objektus, kartais požiūrį, kad suprastume santykių fenomeną (Marc, Picard 2006). Sąveika gali būti pozityvi (bendradarbiavimas, dalyvavimas, prisitaikymas, integracija, sveika konkurencija); negatyvi (konfliktas, kova, lenktyniavimas (varžymasis), segregacija (atsiskyrimas), diskriminacija, įžeidimas), prieštaringa (varžybos, konkurencija).

Šio darbo autorei taip pat priimtinas pasirodè prancūzų sociologo ir filosofo Edgar Morin samprotavimas apie sąveikos svarbą, raišką ir ypatumus. Jis savo filosofiniuose darbuose tiriamus dalykus analizuoja derindamas keturias glaudžioje dinamiškoje sinergijoje veikiančias sąveikos savybes - konfrontaciją, papildymą, konkurenciją, bendradarbiavimą. Sąveika yra suprantama kaip bet kurios sistemos pagrindas, nes jos metu vyksta apsikeitimas informacija, emocijomis arba energija tarp dviejų veikiančiųju vienoje sistemoje (Morin 1980). Galima išskirti du veikimo (sąveikos) tipus. Vienas provokuoja judejjimą, kaitą ir kuria dinaminị efektą. Kitas tipas provokuoja ne judejjimą, bet tik tam tikrus pokyčius (deformacijas), kurie turi statišką efektą. Kraštovaizdžio architektūros ir urbanistikos sprendinių sąveikos tyrime nagrinejjama dinaminio pobūdžio sąveika, kurios rezultatai gali būti tiek fiziniai, tiek psichologiniai ar emociniai. Ši sąveika aprèpia natūralius ir žmogaus kuriamus procesus ir nagrinètina per urboekologinių ir socialinių poreikių bei paslaugų prizmę. Tyrime būtent ir yra orientuojamasi ị žmogaus veiksmų provokuojamą ir kuriamą sąveiką, kuri lemia tolimesnius procesus ir sąveikas.

Kraštovaizdžio architektūros ir urbanistikos veiklos laukas miesto teritorijoje yra praktiškai bendras, tačiau profesijos turi savo takoskyras ir sprendžiamus savo kompetencijos uždavinius. Sąveika dažniausiai išreiškiama ir suvokiama per konkrečius sprendinius, kurių pagrindinis tikslas - tenkinti žmonių poreikius. Ši sąveika gali būti nagrinèjama atskirais aspektais arba kompleksiškai ${ }^{9}$. „Optimizavimas“ žodynuose apibrezžiamas kaip „klausimo ar uždavinio geriausio sprendimo būdo radimas pagal iš anksto nusistatytą kriterijų“. Tyrime optimali sąveika suprantama kaip žmonių veiklos rezultatas, ieškant geriausio sprendimo būdo pagal iš anksto nusistatytus kriterijus. Optimaliai sąveikai būdingas semantikos išsaugojimas, racionalus resursų naudojimas ir perteklinių funkcijų pasikartojimo eliminavimas. Šioje vietoje iškyla pats esmingiausias klausimas - kokių vertybių pagrindu nustatomi optimalumo kriterijai? Kraštovaizdžio architektūrai yra labai artima aplinkos arba ekologinè etika, kurioje

\footnotetext{
${ }^{9}$ Kraštovaizdžio architektūros ir urbanistikos sprendinių saveikos analizės būdai pateikiami B priedo B1 ir B2 lentelëje.
} 
randamos tos pačios vertybès, kaip atmintis (pranc. mémoire), paveldas (pranc. patrimoine), kraštovaizdžio identitetas (pranc. l'identité de paysage), bioịvairovè (pranc. biodiversité), solidarumas (pranc. solidarité), laisvė ir taika (pranc. liberté et paix), geresnè būtis ir geresnis gyvenimas (pranc. mieux-être et mieuxvivre) (Donadieu 2012).

Kraštovaizdžio architektūros ir urbanistikos sprendinių sąveikos optimalumo kriterijams formuotis turi įtakos vietovès geografija, gamtinis kontekstas ir socialinis, ideologinis, kultūrinis kontekstas, kuriuos suderinus tarpusavyje galima tikètis optimalios sąveikos. Tačiau, tikètina, kad kintant „kontekstams“ optimalios sąveikos samprata taip pat kinta, nes miestas, kaip gyvas organizmas nuolat atsinaujina pagal visuomenès raidą ir jos poreikius. Ši raida per sudètingą priežasčių ir pasekmių grandinę keičia materialią miesto struktūrą ir kartu estetinių vertybių skalę (Jurkštas 1994).

Ekologinè etika taip pat apibrèžia tikslingumo ir optimalumo principus: turimų gamtinių ir antropogeninių resursų apsauga bei taupus ir kūrybiškas panaudojimas; konteksto paisymas ir kūrybiškas pritaikymas; socialinių paslaugų sinergija, jų adekvatumas ir vienas kito papildymas; ekologinių, estetinių ir sociofunkcinių klausimų sujungimas į vieningus sprendinius.

Kaip teigia Arnold Berleant, reikia pripažinti, kad nors ir skirtingos, tiek ekologinès, tiek etinès, tiek estetinès vertės žmogaus aplinkoje yra savaip svarbios. Būtų idealu, jei šios vertès viena kitą papildytų. Kita vertus, reikia pripažinti šių verčių skirtumus ir jų nekeičiant jas suderinti ekologinès estetikos ir/arba ekloginès etikos požiūriu. Netgi nebūtina šias vertes harmonizuoti, nes jų tarpusavio „konfliktas“" gali pasitarnauti nustatant, atpažįstant ir vertinant svarbius etinius aspektus, kaupiat ekologinę patirtị ir kitas mokslo žinias, kurios padeda suprasti estetines aplinkos savybes (Berleant 2016).

Optimalumo logika sako, kad prieš priimant bet kokius sprendimus dėl teritorijos vystymo, pirmiausia turime ịsitikinti, kuo ji yra ypatinga, ką joje reikia saugoti, kuo papildyti. O tai reiškia, kad pirmiausia reikia ịsivertinti pasirinktą teritoriją, nustatyti jos stipriąsias ir silpnąsias puses ir, atsižvelgiant ị vertinimo rezultatus, siūlyti optimaliausius tolesnio tvarkymo variantus. Urbanistiniuose procesuose paprastai dalyvauja trys pagrindinès žmonių grupės, kurios vienaip ar kitaip suponuoja sąveikos procesus. Tai - užsakovas (gali būti privatus arba viešas), kūrejas (projektuotojas) ir visuomenè (vartotojas). Bet kuris iš šių trijų veikejjų, gali pirmas pajudinti procesą naujos sąveikos link. Idealu, kai visos trys grupès panašiai supranta ir vertina situaciją, kurioje užgimsta nauja sąveika, ir galima tikètis, kad bus priimti optimalūs sprendimai (2.7 a ir b pav.). 


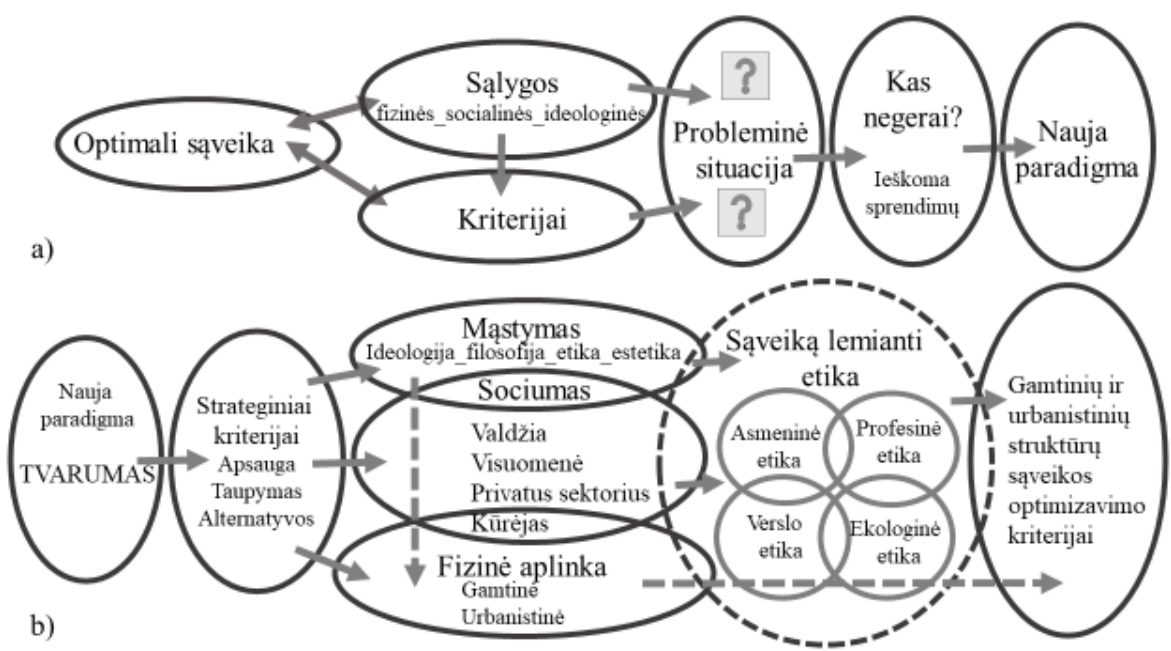

2.7 pav. Sąveikos schema: a) Optimalios sąveikos priklausomybė ir kaita; b) Sąveikos optimizavimo kriterijų formavimas. Šaltinis: V. Deveikienè, 2018

Fig. 2.7. The diagram of interaction: a) dependence and change of interaction optimality; b) formation of interaction optimization criteria.

Source: V. Deveikienè, 2018

Vartojimo problemas nagrinėjantys sociologai pastebi, kad vartojimą vienu atveju galima suprasti kaip neribotų norų, kitu - kaip būtinų poreikių išraišką. Pirmas atvejis - moderniosios visuomenès problema. Besaikis noras eikvoti gamtos gèrybes neretai perauga į norą dominuoti gamtai, valdyti ją. Ir nors, filosofo A. Maceinos tvirtinimu, gamtos apvaldymas nenutraukia žmogaus santykių su gamta, o tik dar labiau juos suriša, tačiau jei šiame ryšyje nebelieka dorinio momento, jis tampa žalingas tiek gamtai, tiek žmogui (Stonkuvienė 2004).

Norėdami užtikrinti optimalius sprendimus turime: (1) labai gerai pažinti nagrinejjamos teritorijos stiprybes ir trūkumus; (2) išnagrinèti konteksto teikiamas galimybes ir sisteminius ryšius; (3) poreikius analizuoti pagal situacijos ir konteksto teikiamas galimybes ir grèsmes; (4) per sinerginius ryšius ieškoti naujų situaciją praturtinančių sprendimų; (5) numatyti galimus gamtinius ir socialinius procesus erdvejje ir laike, taip pat ịsitikinti, ar nesukuriame trukdžių jiems sklandžiai vykti; (6) nusistatyti prioritetus, kuriais vadovaujantis būtų parenkami teritorijos tvarkymo principai ir priemonès. Kraštovaizdžiui ir gyvenamajai aplinkai nagrinèti darbe adaptuota A. Maslow (1908-1970) žmogaus poreikių ir motyvacijos piramide, pagal kurios poreikių skalę interpretuojami kraštovaizdžio tvarkymo lygmenys (2.3 lentelè). 
2.3 lentelė. Kraštovaizdžio tvarkymo lygmenų skalė pagal žmogaus poreikių piramidę (Maslow 1943). Šaltinis: V. Deveikienè, 2018

Table 2.3. The scale of landscape management levels according to the pyramid of human needs (Maslow 1943). Source: V. Deveikienè, 2018

\begin{tabular}{|c|c|}
\hline Žmogaus poreikiai & Aplinka kraštovaizdžio architektūros požiūriu \\
\hline $\begin{array}{l}\text { SAVIREALIZA'CIJOS } \\
\text { POREIKIAI: } 1, \\
\text { dvasingumas, tobùlèjimas, savęs } \\
\text { iprasminimas, Iasmeninių tikslų } \\
\text { iškèlimas ir jụ realizacija }\end{array}$ & $\begin{array}{l}\text { Užtikrinamas aplinkos dvasingumas: vietos } \\
\text { dvasios išsaugojimas ir atskleidimas; kultūrinio } \\
\text { kraštovaizdžio saugojimas ir puoselèjimas; } \\
\text { edukacinių sąlygų sukūrimas; bendruomenès } \\
\text { saviraiškos galimybès; meninès raiškos galimybès, } \\
\text { estetiniai išgyvenimai. }\end{array}$ \\
\hline 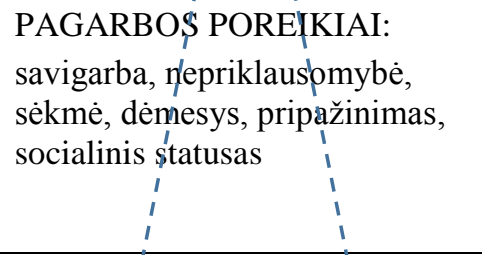 & $\begin{array}{l}\text { Užtikrinama aplinkos kokybė: tvarkinga, patogi } \\
\text { ori aplinka; kompozicinių sprendinių îvairovė, } \\
\text { teikianti pasirinkimo laisvę; visuomenės dalyva- } \\
\text { vimas, pagarba jos nuomonei; optimalūs ir } \\
\text { ekonomiškai pagrįsti sprendiniai; taupus ir } \\
\text { kūrybingas gamtinių resursų naudojimas. }\end{array}$ \\
\hline $\begin{array}{l}\text { SOCIALINIAI POREIKIAI: } \\
\text { bendravimo, draugijos, pasiro- } \\
\text { dymo, stebejjimo, bendradarbia- } \\
\text { vimo, riaudingumo }\end{array}$ & $\begin{array}{l}\text { Užtikrinami socializacijos veiksniai: teritorijų pri- } \\
\text { taikymas įvairioms amžiaus grupems ir įvairiems } \\
\text { poreikiams; neigaliujų integracija; rekreacinių teri- } \\
\text { torijų prieinamumas ir pasiekiamumas; susibūrimo } \\
\text { ir atsitraukimo į nuošalę užtikrinimas. }\end{array}$ \\
\hline $\begin{array}{l}\text { SAUGUMO IR GEROVES } \\
\text { POREIKIAI: } \\
\text { fizinis, emocinis ir materialinis } \\
\text { saugumas, grèsmės vengimas, } \\
\text { svelikata, vaikų saugumas ir là- } \\
\text { vinimas, sportas, grūdinimasis }\end{array}$ & $\begin{array}{l}\text { Užtikrinami saugumą garantuojantys veiksniai: } \\
\text { fizinis aplinkos saugumas; švari sveika aplinka; } \\
\text { sveikatinimo galimybės; pakankamas rekreacinės } \\
\text { teritorijos dydis; gamtinių resursų apsauga; viešo } \\
\text { ir privataus intereso suderinamumas. }\end{array}$ \\
\hline $\begin{array}{l}\text { FlZIOLOGINIAI POREIKIAI! } \\
\text { qras, maistas, fizinis komfortas, } \\
\text { miegas, higiena, mityba, pasto- } \\
\text { gé; judejjimas }\end{array}$ & $\begin{array}{l}\text { Užtikrinamas fiziologinių poreikių tenkinimas: } \\
\text { gryno oro srautai; šviesa/šešèlis; pakankamai } \\
\text { drègmès; apsauga nuo triukšmo; maitinimosi ir } \\
\text { šalinimo poreikių tenkinimas; poilsio ir aktyvumo } \\
\text { poreikių tenkinimas. }\end{array}$ \\
\hline
\end{tabular}

Praktiškai, nagrinėjant bet kurią teritoriją, galima pasidomėti, kokiame žmogaus poreikių skalès lygmenyje yra aplinka. Svarbu ịsisąmoninti šios skalès nuoseklumą - kol nebus sukurtas pagrindas pamatiniams poreikiams, pastangos dél aukštesnès pakopos neturi prasmès. Tačiau kraštovaizdžio architektūros principai leidžia vienu metu aprépti ir sujungti visus poreikių etapus bei numatyti nuoseklų aplinkos kokybės augimą. 


\subsubsection{Trinarès tyrimo kriterijų sistemos sudarymas}

Vadovaujantis tvarumo paradigma, ekologine etika ir optimalumo logika, formuojama trinarè vertinimo kriterijų sistema, susidedanti iš ekologinių, socialinių ir estetinių kriterijų grupių. Tyrimas turi atsakyti i tris pagrindinius klausimus: (1) kokius resursus turime ir kaip juos naudosime; (2) kokius poreikius geriausiai tenkina turimi resursai ir kokių paslaugų mums dar trūksta; (3) ką gali pasiūlyti kraštovaizdžio architektūros principai ir priemonès įsisavinant ir tvarkant teritoriją (2.8 pav.).

\begin{tabular}{|c|c|c|c|c|c|}
\hline \multicolumn{2}{|c|}{$\begin{array}{l}\text { Ekologinis } \\
\text { aspektas }\end{array}$} & \multicolumn{2}{|c|}{$\begin{array}{l}\text { Socialinis } \\
\text { aspektas }\end{array}$} & \multicolumn{2}{|c|}{$\begin{array}{l}\text { Estetinis } \\
\text { aspektas }\end{array}$} \\
\hline & & \multicolumn{2}{|c|}{\ulcorner} & 1 & \\
\hline Ištekliai & $\begin{array}{c}\text { Tvarus } \\
\text { naudojimas }\end{array}$ & $\begin{array}{l}\text { Žmonių } \\
\text { poreikiai }\end{array}$ & $\begin{array}{l}\text { Kokybiškos } \\
\text { paslaugos }\end{array}$ & $\begin{array}{l}\text { Kompozicinès } \\
\text { priemonès }\end{array}$ & $\begin{array}{c}\text { Emocinis } \\
\text { efektas }\end{array}$ \\
\hline \multirow{2}{*}{\multicolumn{2}{|c|}{$\begin{array}{l}\text { Kokius išteklius turime? } \\
\text { Kaip juos naudosime? }\end{array}$}} & \multirow{2}{*}{\multicolumn{2}{|c|}{$\begin{array}{l}\text { Kokius poreikius jie tenkina? } \\
\text { Kokių paslaugų mums reikia? }\end{array}$}} & \multirow{2}{*}{\multicolumn{2}{|c|}{$\begin{array}{l}\text { Ką siūlo kraštovaizdžio } \\
\text { architektūros principai? }\end{array}$}} \\
\hline & & & & & \\
\hline \multicolumn{6}{|c|}{ Ekologinė etika } \\
\hline \multicolumn{2}{|c|}{ Ekologiniai kriterijai: } & \multicolumn{2}{|c|}{ Socialiniai kriterijai: } & \multicolumn{2}{|c|}{ Estetiniai kriterijai: } \\
\hline \multicolumn{2}{|c|}{ Natūralumas } & \multirow{2}{*}{\multicolumn{2}{|c|}{$\begin{array}{c}\text { Pasiekiamumas } \\
\text { |trauktis }\end{array}$}} & \multirow{2}{*}{\multicolumn{2}{|c|}{$\begin{array}{l}\text { Nuoseklumas } \\
\text { Skaitomumas }\end{array}$}} \\
\hline & irovè & & & & \\
\hline \multicolumn{2}{|c|}{ Sukurtos ekosistemos } & \multirow{2}{*}{\multicolumn{2}{|c|}{$\begin{array}{c}\text { Saugumas } \\
\text { Pasidalytos funkcijos }\end{array}$}} & \multirow{2}{*}{\multicolumn{2}{|c|}{$\begin{array}{l}\text { Sudètingumas } \\
\text { Paslaptingumas }\end{array}$}} \\
\hline Ekologin & ajègumas & & & & \\
\hline
\end{tabular}

2.8 pav. Tvarumo ir ekologinės etikos principais sudarytos trinarès vertinimo kriteriju sistemos schema. Šaltinis: V. Deveikienè, 2018

Fig. 2.8. Three-member system of assessment criteria based on the principles of sustainable ecological ethics. Source: V. Deveikienè, 2018

Trys kriterijų grupės sudaromos taip, kad vertinimo rezultatai atskiru aspektu teiktų informaciją arba keltų klausimą kitam aspektui. Pavyzdžiui, aukšti ekologinio vertinimo rezultatai gali pasufleruoti sociofunkcinius prioritetus ir orientuoti i specialias kompozicines priemones estetiniam poveikiui sukurti. Šio vertinimo tikslas išryškinti teritorijos ypatybes - stipriąsias ir silpnąsias puses, kad galètume priimti sprendimus, kaip stiprinti silpnąsias pozicijas, nesilpninant stipriujų. Kiekvieno vertinimo pagrindinis uždavinys ir sëkmès garantas - teisingai ir universaliai parinkti kriterijai.

Vertinant ekologiniu aspektu svarbu išsiaiškinti, ar teritorijoje yra natūralių gamtiniu struktūrų, kurios traktuojamos kaip labai vertinga ir saugotina teritorijos savybė. Antra, yra svarbu susivokti, kokio lygio bioịvairovė mus supa, kad jos nenaikintume neatsakingais veiksmais, o kūrybingai ịtrauktume ị savo terito- 
rijos vystymo planus. Trečia, svarbu įsivertinti, ar teritorijoje egzistuoja sukurtos (arba susikūrusios) ekosistemos, kurios jau gyvena savarankišką gyvenimą ir verta jas išlaikyti, puoselèti arba tobulinti. Ketvirta, reikia išsiaiškinti tiek natūralių, tiek sukurtų gamtinių struktūrų (kitaip tariant, žaliosios infrastruktūros) pajėgumus, esamų urbanistinių sąlygų atžvilgiu. Šiame tyrime taikomi ekologinio aspekto kriterijai: natūralumas (angl. naturalness, wildness), bioịvairovè (angl. biodiversity), sukurtos ekosistemos (angl. built ecosystem), ekologinis pajègumas (angl. ecological carrying capacity). Natūralumas - tai maksimaliai išsaugotos gamtinių struktūrų prigimtinès formos. Pavyzdžiui, gamtinès žemès paviršiaus formos, natūraliai augantys medžiai, krūmai ir žolinè augalija, natūraliai susiformavę vandens telkiniai. Natūralus reljefas tyrime suprantamas kaip gamtos procesų suformuotas žemès paviršius, kuris nèra esmingai pakeistas antropogeninių procesų. Vertinant vandens telkinio natūralumą labai svarbi yra jo prigimtis - upelis, šaltinis, upé, ežeras, jūra ir t. t. Bioįvairove - šiame tyrime vertinama visų rūšių augalijos bioịvairovè, vabzdžiai, paukščiai, žuvys ir kiti gyviai, nuspejami pagal simbiozès principus - jų tikimybè atitinka buveinès dydị. Reljefas vertinamas pagal tai, kaip jis yra pritaikytas atsiskleisti bioịvairovei. Vandens telkinio bioịvairovè vertinama pagal tai, kiek jị supanti augalija sukuria galimybes plėstis bioịvairovei. Suteikiamo balo dydị lemia bioịvairove pasižyminčios teritorijos dydis santykyje su nagrinejjama teritorija. Sukurtos ekosistemos - žalioji infrastruktūra, pagrịsta inovatyviais tvariais inžineriniais sprendiniais. Reljefas vertinamas pagal tai, kaip jo tvarkymo sprendiniai dalyvauja lietaus vandens atviro tvarkymo sistemoje; stogų, terasų, perdangų apželdinime; triukšmo ir oro taršos sulaikymo priemonèse. Vertinant vandenį žiūrimam ar sprendiniuose yra numatytas ar igyvendintas lietaus vandens atviras tvarkymas; apželdinti stogai, kaip lietaus vandens tvarkymo priemoné; sukurta vandens ekosistema; sukauptas vanduo - laistymo priemonè. Taip pat balas suteikiamas teritorijai, kurioje vandeniui laidžios dangos santykis su kietomis dangomis yra 3/2. Ekologinis pajègumas - vertinama, ar natūralios ir sukurtos gamtinès struktūros veikia kaip sistema, ar jos jungiasi tarpusavyje. Žiūrima, kiek stabilios yra gamtinès struktūros, t. y. kiek jos atsparios taršai ar kitam fiziniam poveikiui. Vertinamas gamtinių struktūrų vientisumo ir perforacijos lygis - kuo struktūra yra vientisesnè, tuo jos ekologiniai pajègumai yra didesni. Vertinamos gamtinių išteklių (žemè, oras, vanduo, gyvūnija, augalija) atsinaujinimo galimybès. Svarbus rodiklis taip pat yra užstatytų ir gamtiškų plotų santykis teritorijoje.

Vertinant socialiniu aspektu siekiama išsiaiškinti, kokias socialines funkcijas suponuoja teritorijos vertybės, ị kokias paslaugas protingiausia orientuoti teritorijos vystymo planus, kad būtų geriausiai panaudoti turimi gamtiniai ir antropogeniniai ištekliai ir jų nemažinant kuriamos maksimaliai toje situacijoje pritaikytos paslaugos. Vertinimui socialiniu aspektu formuluojama žmogaus poreikių skalę atitinkanti kriterijų seka - pasiekiamumas (angl. accessibility); 
saugumas (angl. safety); socialinè ịtrauktis (angl. social integration, participation); funkcijų pasidalijimas (angl. shared function). Pasiekiamumas yra susijęs su bazinių poreikių tenkinimu užtikrinant pagrindinius fiziologinius poreikius gryno oro srautus; šviesos ir šešèlio poreikį; žmogui reikalingą ir komfortišką pakankamą drègmès balansą; apsaugą nuo triukšmo ir pan. Vertinant teritoriją svarbu ịsitikinti, ar yra sudaromos bent minimalios rekreacinès sąlygos, ar neužkertami keliai ir patekimai prie rekreacinių resursų; ar garantuojamas poilsio ir aktyvumo poreikių tenkinimas. Vertinama, ar judejimo trajektorijos pritaikytos prie reljefo, ar užtikrintas patekimas ị aukščiausius apžvalgos taškus. Taip pat vertinama, ar užtikrintas priējimas (patekimas) prie vandens telkinio, judejjimas jo pakrante, vizualinis kontaktas. Pasiekiamumas taip pat vertinamas ir teritorijos pritaikymo neịgaliesiems požiūriu. Saugumo kriterijus pirmiausia susijęs su teritorijos priežiūros lygiu. Vertinamas tiek fizinis, tiek socialinis aplinkos saugumas ir faktoriai, kurie gali sukelti saugumo problemų. Nesaugiomis laikomos apleistos, netvarkingos teritorijos, kuriose yra asocialios veiklos požymių. Nesaugiomis taip pat laikomos tiek cheminèmis medžiagomis užterštos, tiek oro tarša ir dideliu triukšmu pasižyminčios teritorijos. Jeigu teritorijoje yra apleistų statinių, ji taip pat laikytina potencialiai nesaugia. Saugumo parametrus mažina aklini fasadai ir tvoros, sunkiai prieinami užkaboriai, duobės ir t. t. Tapti nesaugia teritorija riziką didina didelis automobilių judejjimas, ribojantis pėsčiujų srautus ir komplikuojantis saugų judëjimą. Socialinès ịtraukties kriterijus pirmiausia turi atsakyti, ar bendruomenè suinteresuota savo aplinka, ar yra požymių, kad žmonès linkę bendrai rūpintis aplinka. Socialinès ịtraukties samprata teigia, kad viešosios erdvès turi būti pritaikytos skirtingoms naudojimo paskirtims. Vertinant teritoriją svarbus įvairių suinteresuotų visuomenės grupių dalyvavimas, talkos, bendras ūkininkavimas ir t. t. Vertindami aplinką turètume atsakyti, ar yra sąlygos bendruomenès saviraiškai, ar atskleistas vietos identitetas, sukurti orientyrai ir traukos mazgai. Funkciju pasidalijimo kriterijus nusako, kiek greta esančios funkcijos dera tarpusavyje, kiek jos yra adekvačios ir kiek gali papildyti viena kitą. Žiūrima, ar teikiamos paslaugos turi sinerginį ryši, viena kitos nenuneigia ir nedubliuoja. Vienas iš funkcijų suderinamumo požymių yra integralūs inžineriniai ir kompoziciniai sprendiniai. Suderintomis funkcijomis laikytina kraštovaizdžio architektūros objekto atžvilgiu tinkamai suorientuoti pastatų fasadai ir patekimai, kurie leidžia maitinimo, kultūrines ar rekreacines paslaugas sklandžiai plètoti ir parko ar kitokio želdyno teritorijoje.

Estetinio aspekto kriterijai moksliniuose tyrimuose dažnai nagrinèjami kartu su ekologiniais socialiniais kriterijais neišskiriant jų atskira grupe. Vokietijos urbanistinès kompozicijos tyrejjai G. Franz, M. von der Heyde ir H. H. Bülthoff viename iš mokslinių straipsnių pateikia tokius urbanistinès kompozicijos kokybės kriterijus - erdvumas (angl. spaciousness); atvirumas (angl. openness); sudètingumas (angl. complexity); tvarka (angl. order) (Franz et al. 2003). Jungtinès 
Karalystės Architektūros ir urbanizuotos aplinkos komisijos rekomendacijų viešosioms erdvėms dokumente Start with park (2005) išskiriamos aštuonios kokybinès erdvès charakteristikos - darnumas, charakteris ir išskirtinumas, aiškios ribos, ryšiai ir pasiekiamumas, skaitomumas, adaptyvumas, itrauktis ir biologiné įvairove. Europos komisijos tarptautinio projekto Žalioji infrastruktūra ir urbanistinis planavimas (angl. Green Structure and Urban Planning, general outcomes of COST C11) pagrindineje ataskaitoje Delfto (Nyderlandai) technologijos universiteto profesorius S. Tjallingii išskiria žmogaus visapusiškai sveikatai svarbius žaliujjų erdvių kokybinius kriterijus: psichologinès kokybės požiūriu natūralumas, sodrumas, ramumas, iliuziškumas, bendrumas, vaizdingumas, šventiškumas, esmiškumas; projekto kokybès požiūriu - įskaitomumas, nuoseklumas, sudètingumas, paslaptingumas (Tjallingii 2005). Viena iš plačiausiai žinomų aplinkos psichologijos teorijų - mokslininkų Rachel ir Stephen Kaplan (Kaplan\&Kaplan 1989; Stamps III 2004) tyrimo modelis - paslaptingumas (angl. mystery); sudètingumas (angl. complexity); įskaitomumas (angl. legibility); darna (angl. coherence) (2.4 lentelè).

2.4 lentelè. Estetinio suvokimo kriterijai. Sudaryta pagal R. ir S. Kaplan, 1989

Table 2.4. The criteria of aesthetic perception. According to R\&S Kaplan, 1989

\begin{tabular}{|l|l|l|}
\hline \multicolumn{1}{|c|}{ Kriterijus } & Suvokimo tipas & \multicolumn{1}{c|}{ Vertinimo klausimas } \\
\hline $\begin{array}{l}\text { Darna } \\
\text { (coherence) }\end{array}$ & $\begin{array}{l}\text { Tiesioginis } \\
\text { supratimas }\end{array}$ & $\begin{array}{l}\text { Ar vaizdai dera tarpusavyje? Ar lengvai suvo- } \\
\text { kiama aplinkos struktūra ir kompozicija? }\end{array}$ \\
\hline $\begin{array}{l}\text { Sudėtingumas } \\
\text { (complexity) }\end{array}$ & $\begin{array}{l}\text { Tiesioginis } \\
\text { tyrinejjimas }\end{array}$ & $\begin{array}{l}\text { Ar ịdomu stebèti aplinką? Ar gausi vaizdụ ịvai- } \\
\text { rovè? }\end{array}$ \\
\hline $\begin{array}{l}\text { Iskaitomumas } \\
\text { (legibility) }\end{array}$ & $\begin{array}{l}\text { Nuspejjimas } \\
\text { supratimas }\end{array}$ & $\begin{array}{l}\text { Ar lengva ịsivaizduoti tolimesnị kelią einant } \\
\text { pirmyn ir atgal? Ar paprasta orientuotis aplin- } \\
\text { koje? }\end{array}$ \\
\hline $\begin{array}{l}\text { Paslaptingumas } \\
\text { (mystery) }\end{array}$ & $\begin{array}{l}\text { Nuspėjamas } \\
\text { tyrinejjimas }\end{array}$ & $\begin{array}{l}\text { Kiek daug žada matomas kraštovaizdis, jei būtų } \\
\text { einama toliau? Ar kelia susidomèjimą dar ne- } \\
\text { matomi vaizdai? }\end{array}$ \\
\hline
\end{tabular}

Ši teorija grịsta dviem pagrindiniais žmogaus poreikiais aplinkai - ją suprasti (angl. to understand) ir tyrinèti (angl. to explore). Vadovaujantis šiuo principu ir buvo išskirti keturi pagrindiniai aplinkos emocinio išgyvenimo arba estetinio pajautimo kriterijai, kuriuos mokslininkai grupuoja ị tiesioginio supra- 
timo (angl. immediate understanding) bei tiesioginio tyrinejjimo (angl. immediate exploration) ir nuspejamo supratimo (angl. inferred understanding) ir nuspèjamo tyrinejjimo (angl. inferred exploration) grupes. Atsižvelgiant $\mathfrak{i}$ tai, kad miesto erdvių ir kraštovaizdžio formavimui naudojamos labai įvairios kompozicinès priemonès turi tikslą sukelti vienokią ar kitokią žmonių reakciją arba emociją, pasirinkta gamtinių ir urbanistinių struktūrų sąveiką vertinti aukščiau aptartais estetinio poveikio kriterijais.

\subsubsection{Eksperimentinis teritorijos tyrimas taikant erdvinių gardelių tinklo metodą}

Tyrimui pasirinkti kvartalai, esantys šiaurinèje Vilniaus dalyje, kurių pagrindinis urbanistinis karkasas suformuotas apie 1980-1990 metus, tačiau gana intensyviai plètojamas ir dabartiniu metu. Tiriama teritorija apima Pašilaičių, Fabijoniškių, Šeškinès, Viršuliškių ir kitus tankiai gyvenamus mikrorajonus. Tyrime koncentruojamasi i kvartalo lygmens problematiką. Tyrimo metu nagrinejjama teritorijos gamtinių ir urbanistinių struktūrų sąveika, pastarają traktuojant kaip svarbų kraštovaizdžio architektūros kūrybinès veiklos lauką. Siekiant aprèpti kuo daugiau potencialios kraštovaizdžio architektūros raiškos situacijų, pasirinkta tirti ne konkrečius objektus, bet nagrinèti ištisinę probleminę miesto teritoriją, ją vientisai padengiant erdvine gardele. Tyrimo pagrindui naudojama ortofoto nuotrauka ir kiti GIS duomenys bei fotografijos. Teritorija vientisai padengiama $1 \mathrm{kv}$. km dydžio erdvine gardele, kuri atitinka kvartalo lygmens skaidymą. (2.9 a pav.). Tokio dydžio etaloninès gardelès metodas yra taikomas Europos kraštovaizdžio monitoringo sistemose ir Lietuvoje specialistams rekomenduojama pereiti prie vieningos kraštovaizdžio monitoringo sistemos (Veteikis et al. 2015). Nagrinèjamos 25 gardelès, kurios iš viso padengia $25 \mathrm{kv}$. km teritoriją. Pasak J. Zagorsko, egzistuoja tam tikri „lūžio taškai“, kai keliaujantis asmuo priklausomai nuo atstumo renkasi judejimo būdą. Yra žinoma, kad, turèdami atlikti 10 minučių kelionę pésčiomis, didžioji dauguma žmonių nesvarstydami ir rinksis kelionę pėsčiomis. 10 minučiu kelionè pėsčiomis atitinka 500-600 m atstumą. Taigi objektai, esantys šiuo atstumu, turès itin stiprią tarpusavio trauką (Zagorskas 2007).

Analizuojant 1 kv. km gardeles pastebèta, kad vienoje tokio dydžio gardelèje galima aptikti gana ịvairias urbanistinių ir gamtinių struktūrų sąveikos formas, tačiau jos yra apibendrintos, atspindinčios sisteminius sąveikos bruožus. Nuspręsta, kad teritorinius tyrimo vienetus reikia skaidyti iki dar mažesnio vieneto $500 \times 500$ m dydžio subgardelès (2.9 b pav.), kurioje geriausiai išryškejja būdingi vienalyčiai urbanistinių ir gamtinių elementų fizinès sąveikos bruožai. Be to, tokio dydžio teritorija yra suvokiama pėsčiojo. 
a)
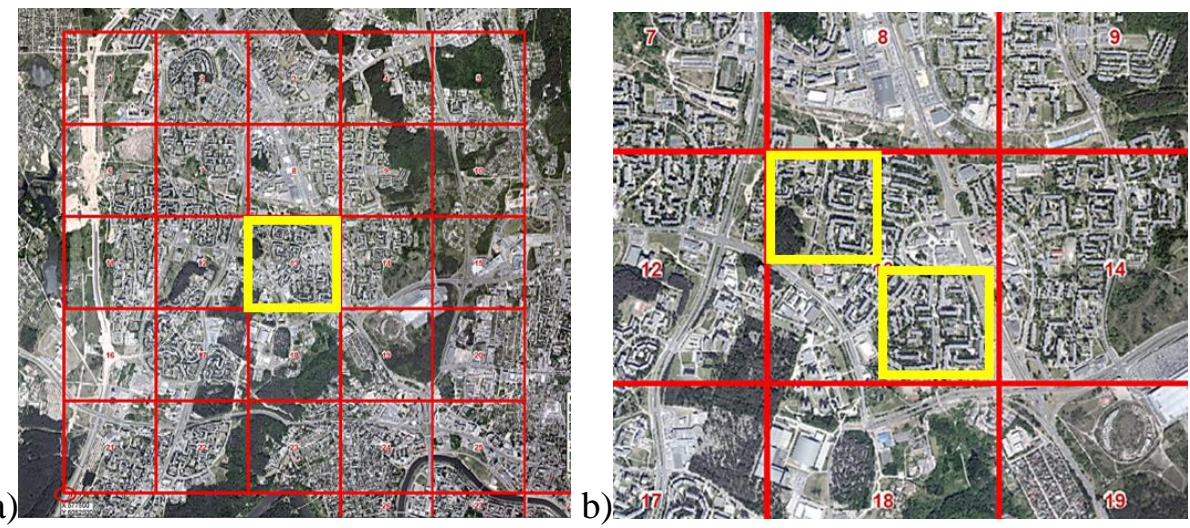

2.9 pav. Tyrimo teritorija: a) šiaurinè Vilniaus miesto teritorija, vientisai padengta $1 \mathrm{kv}$. km dydžio erdvine gardele; b) skaidymo iki subgardelès $(500 \times 500 \mathrm{~m})$ pavyzdys. Šaltinis: V. Deveikienè, 2018

Fig. 2.9. The area of research: a) northern territory of the city of Vilnius as covered with 1 square. $\mathrm{km}$ spatial grid; b) example of division to sub-grids $(500 \times 500 \mathrm{~m})$.

Source: V. Deveikienè, 2018

Tyrimui buvo parengta 100 tiriamų teritorinių vienetų. Jų pirminès analizès metu pastebèta, kad atskirose gardelèse gamtinių ir urbanistinių struktūrų sąveikos bruožai turi bendrumų, kuriuos galima sugrupuoti išskiriant tam tikrus fizinès sąveikos tipus. Konkretaus tyrimo dabartiniame etape išsami urbanistinio kraštovaizdžio morfologinè analizè nèra atliekama, tačiau iš esmès jai artimas skirstymas pagal būdingus gamtinių ir urbanistinių struktūrų fizinès sąveikos bruožus leistų tolimesniuose etapuose tyrimo rezultatus vystyti ir interpretuoti taip pat ir morfologiniu požiūriu. Pateikiamas nagrinèjamos šiaurinès Vilniaus miesto teritorijos subgardelių $(500 \times 500 \mathrm{~m})$ skirstymas pagal dominuojančius fizinès sąveikos bruožus . Skirstymo pagal atskirose gardelèse dominuojančius gamtinių ir urbanistinių struktūrų fizinės sąveikos bruožus variantas pateikiamas B priedo B19 paveiksle.

Aktualus tyrimas, vertinant gamtinių ir urbanistinių struktūrų sąveikos ypatumus, atliekamas atskirose gardelèse $(500 \times 500 \mathrm{~m})$. Siekiant objektyvumo, tyrimui gardelès pasirenkamos atsitiktinai, biopsijos principu, nes atsitiktinis stebėsenos etalonų išdèstymas daugelyje mokslo darbų pripažintas kaip korektiškiausias (Veteikis et al. 2015).

Pateikiamas gardelès 13.4 pavyzdys. Nagrinèjama teritorija yra Šeškinès mikrorajone, pastatytame apie $1980 \mathrm{~m}$. Čia dominuoja laisvo planavimo daugiabučiai gyvenamieji 5-9 aukštų gelžbetonio blokų konstrukcijos namai, kurie pasižymi ilgomis fasadų kraštinėmis, pastatus komponuojant L raide ir sukuriant pusiau uždaras kiemų erdves. Nagrinëjamoje erdvinejje gardelèje yra dvi ikimo- 
kyklinio ugdymo ịstaigos su pakankamai erdviomis atitvertomis teritorijomis. Pastatai veidrodiškai išsidèstę abipus pėsčiųų tako, einančio šiaurès pietų kryptimi. Reljefas mažai išraiškingas, turi bendrą nuolydį šiaurès pietų kryptimi. Pagal gamtinių ir urbanistinių struktūrų fizinès sąveikos dominuojančius bruožus nagrinejjama gardelè priskiriama tipui „Daugiabučių gyvenamųų namų vidinės atviros erdvès" (2.10 pav.).
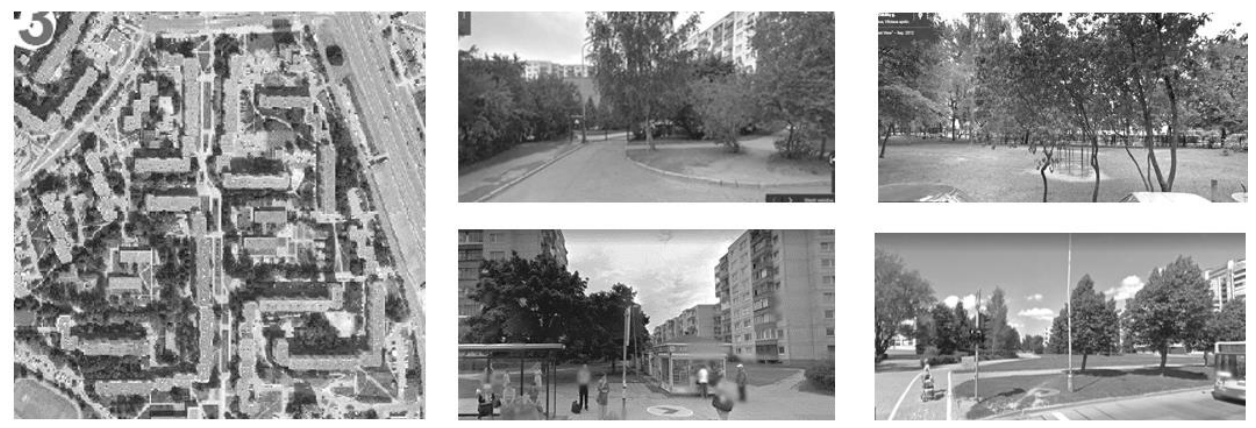

2.10 pav. Tyrimui naudojama teritorinè erdvinè $500 \times 500 \mathrm{~m}$ gardelè (13.4) ir šiai teritorijai būdingi vaizdai. Šaltinis: V. Deveikienè, 2018

Fig. 2.10. The spatial grid (13.4) of $500 \times 500 \mathrm{~m}$ was used for the research and and the pictures typical of this area. Source: V. Deveikiene, 2018

Taikant subjektyvaus ekspertinio vertinimo metodą gamtinių ir urbanistinių struktūrų sąveika vertinama atskiruose trinarès kriterijų sistemos klasteriuose, skiriant balus nuo 1 iki 5, kur 1 balas - labai silpnai išreikšta; 2 - silpnai išreikšta; 3 - vidutiniškai išreikšta; 4 - stipriai išreikšta; 5 - labai stipriai išreikšta sąveika. Jei kurio nors gamtinès struktūros elemento nèra - rašomas nulis.

Kaip matoma 2.5 lentelèje, vieno iš aspektų kriterijų grupejje gaunama 60 vertinimo duomenų - trijų gamtinių elementų sąveika su penkiais urbanistinès struktūros elementais vertinama keturių kriterijų atžvilgiu. Iš 2.5 lentelèje pateiktų rezultatų matyti, kad vertinant ekologiniu požiūriu sąlyginai aktyviausiai gamtinių ir urbanistinių elementų sąveika išreikšta ribose (20 balų), o mažiausiai - vietoženkliuose (12 balų). Augalijos raiška (43 balai) yra didesnė už reljefo raišką (33 balai), o vandens teritorijoje praktiškai nèra ( 2.5 lentelè).

Atitinkamai vertinimas atliekamas ir kitose socialinio bei estetinio aspektu kriterijų grupèse (2.6 lentelè). 
2.5 lentelè. Gamtinių ir urbanistinių struktūrų sąveikos vertinimas balais ekologiniais kriterijais (13.4 gardelès vertinimo duomenys). Šaltinis: V. Deveikienè, 2018

Table 2.5. Example assessment of interaction between natural and urban structures in ecological criteria cluster (evaluation data of the grid 13.4). Source: V. Deveikienè, 2018

\begin{tabular}{|c|c|c|c|c|c|c|c|c|c|c|c|c|c|c|c|c|c|c|c|c|c|}
\hline \multirow[b]{2}{*}{13.4} & \multicolumn{4}{|c|}{ Jungtys } & \multicolumn{4}{|c|}{ Ribos } & \multicolumn{4}{|c|}{ Mazgai } & \multicolumn{4}{|c|}{$\begin{array}{l}\text { Vietoženk- } \\
\text { lija }\end{array}$} & \multicolumn{3}{|c|}{ Kvartalai } & \multirow{2}{*}{\multicolumn{2}{|c|}{ 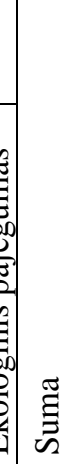 }} \\
\hline & 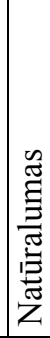 & 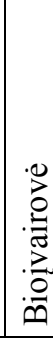 & 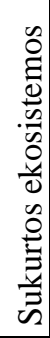 & 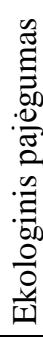 & 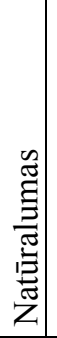 & $\begin{array}{l} \\
\\
0 \\
0 \\
0 \\
0 \\
0 \\
0 \\
0 \\
0 \\
0 \\
0\end{array}$ & 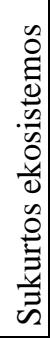 & 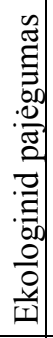 & 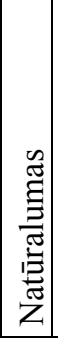 & $\begin{array}{l}.0 \\
0 \\
.0 \\
.0 \\
.0 \\
.0 \\
.0 \\
\end{array}$ & 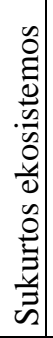 & 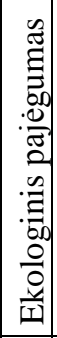 & 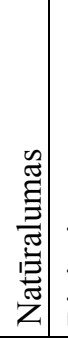 & $\begin{array}{l} \\
0 \\
0 \\
0 \\
0 \\
0 \\
0 \\
0 \\
0 \\
0\end{array}$ & 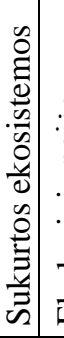 & 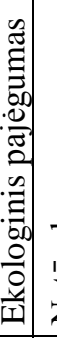 & 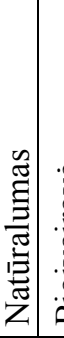 & : & 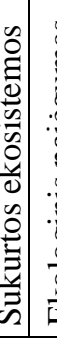 & & \\
\hline Žemè & 2 & 2 & 1 & 1 & 3 & 3 & 2 & 1 & 2 & 2 & 1 & 1 & 2 & 2 & 1 & 2 & 2 & 1 & 1 & 3 & 3 \\
\hline Vanduo & 0 & 0 & 0 & 0 & 0 & 0 & 0 & 0 & 0 & 0 & 0 & 0 & 0 & 0 & 0 & 0 & 0 & 1 & 0 & ) & \\
\hline Augalai & 3 & 3 & 2 & 1 & 3 & 3 & 3 & 2 & 3 & 2 & 2 & 1 & 2 & 2 & 1 & 3 & 3 & 2 & 1 & 4. & 3 \\
\hline \multirow{2}{*}{ Suma } & 5 & 5 & 3 & 2 & 6 & 6 & 5 & 3 & 5 & 4 & 3 & 2 & 4 & 4 & 2 & 5 & 5 & 4 & 2 & \multirow{2}{*}{\multicolumn{2}{|c|}{77}} \\
\hline & \multicolumn{4}{|c|}{15} & \multicolumn{4}{|c|}{20} & \multicolumn{4}{|c|}{14} & \multicolumn{4}{|c|}{1} & \multicolumn{3}{|c|}{15} & & \\
\hline
\end{tabular}

2.6 lentelè. Apibendrinti gamtinių ir urbanistinių struktūrų sąveikos vertinimo rezultatai (13.4 gardelès vertinimo duomenys). V. Deveikienè, 2018.

Table 2.6. Summarised results of evaluation of the interaction of natural and urban structures in grid 13.4. By V. Deveikienè, 2018

\begin{tabular}{|c|c|c|c|c|c|c|c|c|c|c|c|c|c|}
\hline $\begin{array}{l}\text { Kriteriju } \\
\text { klasteriai }\end{array}$ & \multicolumn{4}{|c|}{$\begin{array}{l}\text { Ekologinis } \\
\text { aspektas }\end{array}$} & \multicolumn{4}{|c|}{$\begin{array}{l}\text { Socialinis } \\
\text { aspektas }\end{array}$} & \multicolumn{4}{|c|}{$\begin{array}{l}\text { Estetinis } \\
\text { aspektas }\end{array}$} & \multirow{2}{*}{$\begin{array}{l}\text { Bendra } \\
\text { suma }\end{array}$} \\
\hline $\begin{array}{l}\text { Sąveikos } \\
\text { objektai }\end{array}$ & 苞 & 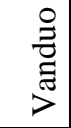 & $\begin{array}{l}\cdot \bar{\pi} \\
\frac{\pi}{\pi} \\
\frac{00}{2}\end{array}$ & 音 & 咆 & 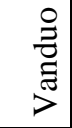 & $\begin{array}{l}\cdot \pi \\
\frac{\pi}{7} \\
0 \\
\bar{\alpha} \\
\end{array}$ & $\stackrel{\widetilde{g}}{\Xi}$ & 恕 & $\begin{array}{l}\stackrel{0}{\Xi} \\
\bar{\Xi} \\
\stackrel{\Xi}{>}\end{array}$ & 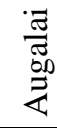 & $\begin{array}{c}\tilde{a} \\
\stackrel{\Xi}{\Xi}\end{array}$ & \\
\hline Jungtys & 6 & 0 & 9 & 15 & 8 & 0 & 8 & 16 & 6 & 0 & 9 & 15 & 46 \\
\hline Ribos & 9 & 0 & 11 & 20 & 7 & 0 & 9 & 16 & 9 & 0 & 11 & 20 & 56 \\
\hline Mazgai & 6 & 0 & 8 & 14 & 7 & 0 & 8 & 15 & 6 & 0 & 8 & 14 & 43 \\
\hline $\begin{array}{l}\text { Vieto- } \\
\text { ženkliai }\end{array}$ & 6 & 0 & 6 & 12 & 6 & 0 & 6 & 12 & 6 & 0 & 6 & 12 & 36 \\
\hline Kvartalai & 6 & 1 & 9 & 16 & 6 & 0 & 9 & 15 & 6 & 0 & 9 & 15 & 46 \\
\hline Suma & 33 & 1 & 43 & 77 & 34 & 0 & 40 & 74 & 33 & 0 & 43 & 76 & 227 \\
\hline
\end{tabular}


Pasirinktas vertinimo būdas leidžia situaciją nagrinèti daugybe pjūvių, pagal poreikį grupuojant ar sumuojant duomenis. Bendras 13.4. gardelès vertinimo ekologiniu aspektu ịvertinimas yra 77 balai. Gauti teritorijos gamtinių ir urbanistinių struktūrų sąveikos vertinimai ekologinio, socialinio ir estetinio aspektų kriterijais yra gana panašūs tarpusavyje - atitinkamai 77, 74, 76 balai. Tai rodo, kad teritorija neturi labai išskirtinių sąveikos savybių, o pats sąveikos lygis yra gana žemas - kiekvienos iš pozicijų gautas vertinimas nesiekia $30 \%$ galimos balų sumos (maksimali galima suma yra 300 balų). Kaip teigia E. K. Zavadskas, kriterijų reikšmingumai ir kokybinių kriterijų reikšmès dažniausiai apskaičiuojamos remiantis ekspertiniais metodais. Atsižvelgiant ị tai, kad atskirai vertinimo balai neatspindi vertinimo rezultato santykio maksimaliai įmanomu balu, vertinimo rezultatų išraiška perskaičiuojama taikant kokybinių kriterijų reikšmingumo skaičiavimo formulę (Zavadskas et al. 1999). Pateikiama nagrinėjamos 13.4 gardelès vertinimo metu gautų verčiu ir maksimalios vertès santykio grafinè išraiška (2.11 pav.).

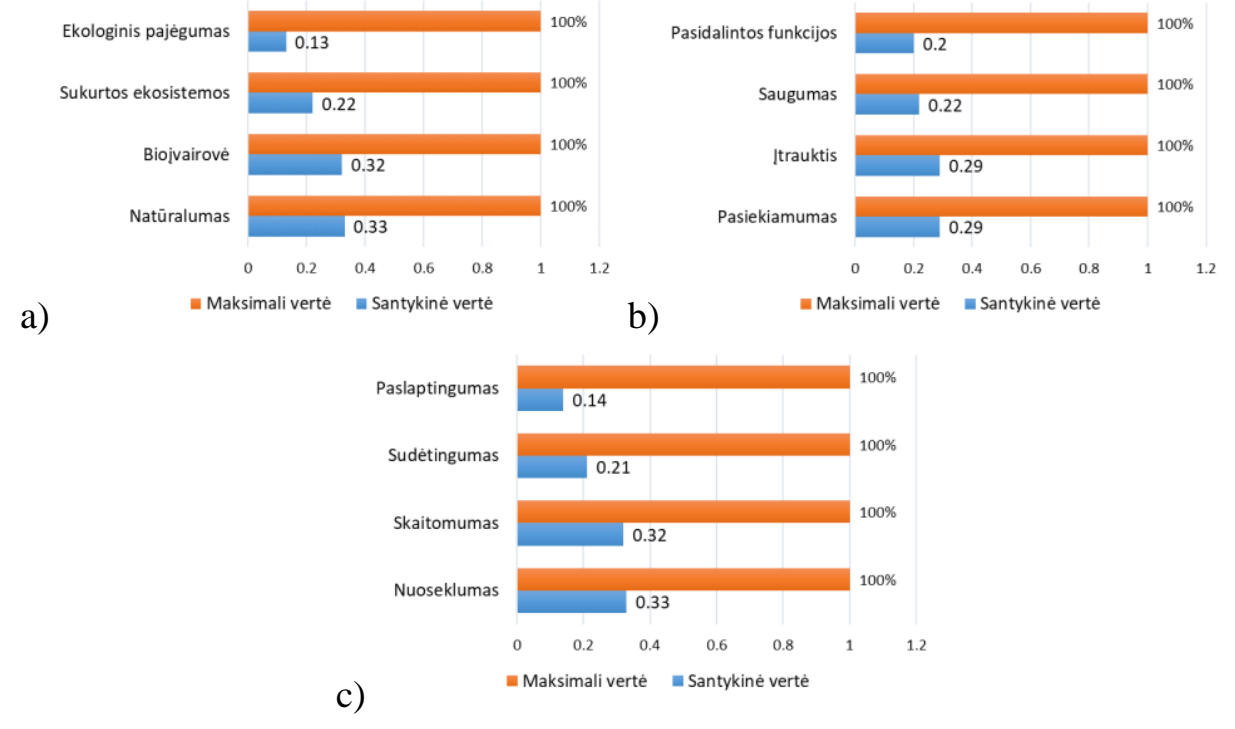

2.11pav. Gamtinių ir urbanistinių struktūrų sąveikos santykinès vertè grafinè išraiška.

13.4 gardelè: a) ekologinis aspektas b) socialinis aspektas, c) estetinis aspektas Šaltinis: V. Deveikienè, 2018.

Fig. 2.11. The relative values of interaction between natural and urban structures Grid 13.4.: a) ecological aspect, b) social aspect, c) aesthetic aspect.

Source: V. Deveikienè, 2018. 
Vertinimo rezultatu analizès metu nustatomos teritorijos stipriosios ir silpnosios pusès yra santykinès - jos išskiriamos lyginant duomenis tarpusavyje. Pavyzdžiui, visose trijose kriterijų grupèse augalai (40-43 balai) yra aktyvesnèje sąveikoje su urbanistinèmis struktūromis negu reljefas (30-34 balai). Tiek augalų, tiek reljefo raiška yra stipriausia ribose, vertinant ekologiniu ir estetiniu aspektu. Mažiausiai gamtinių ir urbanistinių elementų sąveika išreikšta formuojant vietoženklius. Sąveikos vertinimo rezultatai detaliau analizuojami kriterijų grupèse arba klasteriuose, kur pagal kiekvieną iš subkriterijų įmanomas maksimalus 75 balų vertinimas. Daugiausia balų suteikta ,natūralumui“ (25) vertinant ekologiniu aspektu ir „darnai“ (25) vertinant estetinio poveikio aspektu. Atitinkamai antroje vietoje atsiduria vertinimai pagal subkriterijus „,bioịvairove“" ir „skaitomumas“ (po 24 balus). Mažiausiais balais ịvertinti teritorijos „ekologinis pajègumas“ (11) ir „paslaptingumas“ (11). Vertinimai tarp socialinio aspekto klasterio subkriterijų pasiskirsto tolygiau, šiek tiek aukštesnị balą - santykinai didžiausią balą - suteikiant pagal subkriterijus, „itrauktis“ ir „pasiekiamumas“.

Sąlyginai aukštesni natūralumo bioịvairovès balai aiškintini tuo, kad teritorijoje augantys želdiniai daugiausia yra vietinių rūšių, todèl prisideda prie natūralios aplinkos formavimo, o taip pat prie tam tikro lygio bioịvairovès, kuri yra šiek tiek atsitiktiné, besikurianti dèl kuklios mechaninès ir cheminės želdinių priežiūros, taip nevalingai sudarant sąlygas plètotis nors ir nedidelèms gamtinèms bendrijoms. Tiek ekologiniu, tiek socialiniu požiūriu želdiniai geriausiai atsiskleidžia sąveikoje su ribomis - daugiausia daugiabučių namų kiemuose, ties takais ir ikimokyklinio ugdymo įstaigų aptverimu. Jie taip pat yra ryškūs jungtyse (paths), tai paaiškina sąlyginai išsiskiriantị ,,pasiekiamumo“ balą, kuris suteikiamas vertinant gyventojų galimybes lengvai prieiti prie gamtinių struktūrų ir naudotis jų teikiamomis paslaugomis. Estetiniu požiūriu ryškiausia želdinių sąveika yra ribose, ypač vertinant darnos kriterijumi, nes vieningai suplanuotose urbanistinèse erdvėse želdinių, reljefo ir statinių santykis yra aiškiai suvokiamas ties pėsčiujų takais.

Vertinant gamtinių ir urbanistinių struktūrų sąveiką, kiekvienoje gardelëje atskiru aspektu gaunama po 60 vertinimo pozicijų. Apimant visas tris kriterijų grupes vertinimo duomenis ir rezultatus sudaro 180 punktų, kuriuos galima nagrinèti ịvairiais pjūviais. Šių vertinimo rezultatų interpretacija gali būti naudinga tiek vertinimo, tiek prioritetu nustatymo, tiek projektavimo etapuose. Subjektyvaus ekspertinio tyrimo metodu, pagal sudarytą trinarę kriterijų sistemą atlikto vertinimo rezultatų interpretacija išryškina teritorijoje vykstančios gamtinių ir urbanistinių struktūrų bruožus - sąlyginai stipresnes ir silpnesnes tos sąveikos puses. Pavyzdžiu pateikiame 13.4 gardelès vertnimo apibūdinimą. Stipriosios teritorijos savybės: (1) pakankamai natūralūs želdiniai ir galimybė formuotis bioịvairovès apraiškoms; (2) aiški pagrindinè teritorijos urbanistinė struktūra, kuri lemia, kad stebint aplinką išgyvenamas tam tikras estetinis darnos pojūtis, 
vaizdai ir judejjimo trajektorijos yra ịskaitomi; (3) gamtinių struktūrų pasiekiamumas, išreikštas per reljefo, želdinių ir jungčių (kelių) sąveiką; (4) pusiau atvirų kiemų struktūros ir ikimokyklinio ugdymo ịstaigų žaliosios erdvės kuriančios sąlygas bendruomenès saviraiškai. Silpnosios teritorijos savybės: (1) mažas ekologinis pajègumas ir naujų eko-sistemų stoka; (2) nẻra nei natūralių, nei dirbtinių vandens telkinių; (3) priežiūros trūkumas ir neorganizuotas automobilių statymas sukuria nesaugios aplinkos įspūdį; (4) Teritorijai trūkta vietoženklių ir aiškiai suformuotų mazgų, kuriuose svarbų vaidmeni galètų atlikti reljefas, želdiniai ir vanduo; (5) trūksta patrauklių vaizdų ir intriguojančio paslaptingumo, dèl to yra silpnai išreikštas vietos identitetas, erdvès ir vaizdai neskatina jose ilgiau užsibūti.

Nežiūrint to, kad vertinimo rezultatai yra interpretuojami išskiriant stipriąsias ir silpnąsias gamtinių ir urbanistinių struktūrų sąveikos puses, išlieka objektyvizuotų prioritetų nustatymo problema, kuri sprendžiama naudojant daugiakriterinès analizės metodą ir keliant klausimą, kuris atskiro kriterijų klasterio subkriterijus yra svarbesnis konkrečioje teritorijoje. Pateikiame pavyzdį, kaip, taikant analitinès hierarchijos proceso (AHP) metodą, kriterijų prioritetai nustatomi vertinant juos poromis pagal jų svarbą konkrečioje 13.4 gardelès teritorijoje. Kriterijų svarba vienas kito atžvilgiu vertinama suteikiant balus nuo 1 iki 9. Skaičiavimas buvo atliekamas naudojant laisvos internetinès prieigos prioritetų skaičiuoklę AHP-OS (https://bpmsg.com/academic/ahp.php). Prioritetu nustatymo procesas iliustruojamas 2.12 paveiksle.
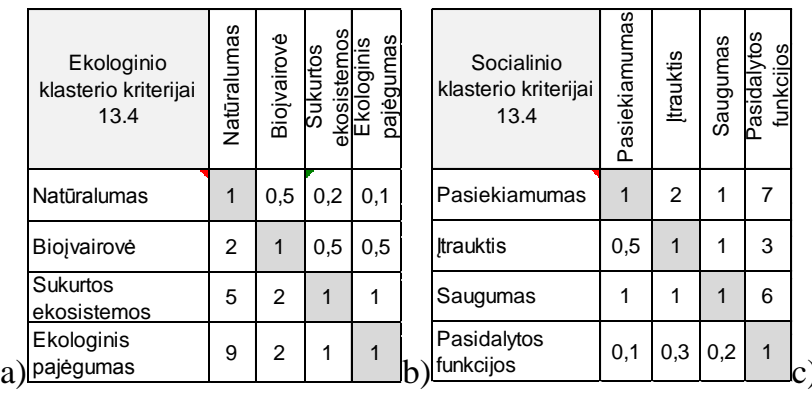

\begin{tabular}{|c|c|c|c|c|}
\hline $\begin{array}{c}\text { Estetinio klasterio } \\
\text { kriterijai } \\
13.4\end{array}$ & 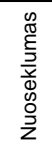 & 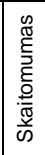 & 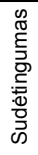 & 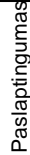 \\
\hline Nuoseklumas & 1 & 1 & 8 & 4 \\
\hline Skaitomumas & 1 & 1 & 5 & 5 \\
\hline Sudètingumas & 0,12 & 0,2 & 1 & 1 \\
\hline Paslaptingumas & 0,25 & 0,2 & 1 & 1 \\
\hline
\end{tabular}

2.12 pav. Prioritetų nustatymo procesas taikant laisvos internetinès prieigos skaičiuoklę AHP-OS: a) ekologinis aspektas; b) socialinis aspektas; c) estetinis aspektas Šltinis: V. Deveikienè, 2018

Fig. 2.12. The prioritization process using the AHP-OS free internet access spreadsheet: a) ecological aspect; b) social aspect; c) aesthetic aspect. Source: V. Deveikienė, 2018

Taikant daugiakriterinės analizės metodą, atskiruose kriterijų klasteriuose nustatomas subkriterijų prioritetinis eiliškumas. Ekologinių kriterijų klasteryje ị pirmą vietą iškyla ekologinio pajègumo ir sukurtų ekosistemų svarba, socialiniu 
požiūriu svarbios išlieka trys pozicijos, atitinkamai - pasiekiamumas, saugumas ir ịtrauktis. Estetiniu požiūriu ryškus prioritetas teikiamas darnos ir skaitomumo subkriterijams. Lyginant esamos situacijos vertinimo balais rezultatus ir daugiakriterinès analizès būdu nustatytus pageidaujamus prioritetus, atskiruose kriteriju klasteriuose išryškejja specifiniai probleminiai gamtinių ir urbanistinių struktūrų sąveikos klausimai. Ekologiniu aspektu vertinamos teritorijos stiprioji pusė natūralumas - pagal prioritetų skalę yra mažiausiai reikšmingas, o silpnoji pusè ekologinis pajegumas - yra vienas svarbiausių pageidaujamų prioritetų. Socialinių kriterijų klasteryje stiprioji pusė yra pasiekiamumas ir šis kriterijus išlieka svarbiausias nustatant prioritetus. Antru pagal svarbą iškeliamas saugumo prioritetas, tačiau pagal jị vertinant esamą padètị buvo suteiktas mažiausias balas. Estetinio aspekto kriterijų klasteryje prioritetiniais kriterijais išskirti darna ir skaitomumas, pagal kuriuos ekspertinio situacijos vertinimo metu gamtinių ir urbanistinių struktūrų sąveika ịvertinta taip pat santykinai aukštais balais. Tyrimo rezultatų interpretacijos požiūriu įdomiausios ir aktualiausios yra didžiausių nesutapimų tarp esamos situacijos vertinimo ir poreikių prioritetu vietos, kurios iš esmès parodo prioritetinių veiklų kryptị (2.13 pav.).

a)
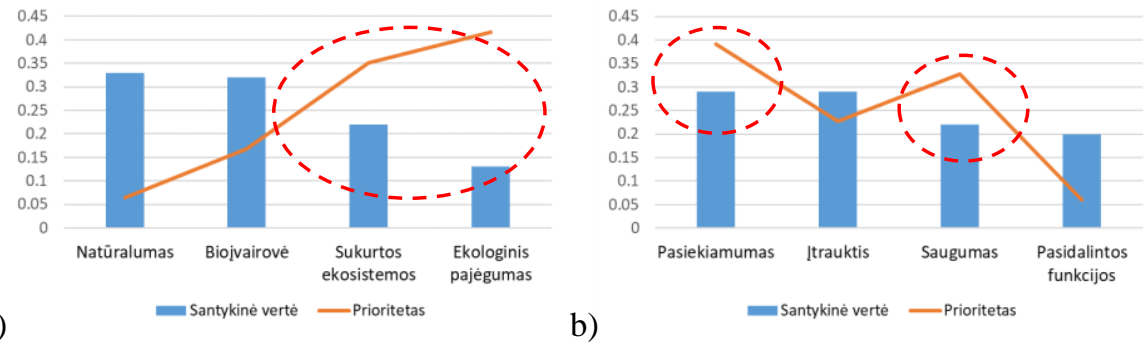

b)

Santykinè vertè —Prioritetas

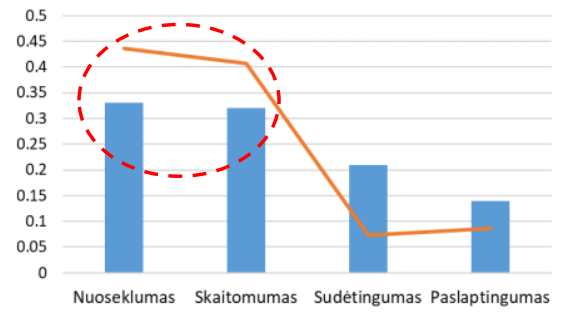

c)

- Santykinè vertè —Prioritetas

2.13 pav. Ekspertinio vertinimo metu nustatytų verčių ir daugiakriterinès analizės būdu išskirtų prioritetu santykio grafinè išraiška. 13.4 gardelè: a) ekologinis aspektas

b) socialinis aspektas, c) estetinis aspektas. Šaltinis: V. Deveikienè, 2018

Fig. 2.13. The graphical expression of the relationship between the values set by the expert evaluation and the priority ratios distinguished by multi-criteria analysis.

Grid 13.4.: a) ecological aspect, b) social aspect, c) aesthetic aspect.

Source: V. Deveikienè, 2018 
Tarkime, 13.4 gardelès atveju, nagrinèjant ekologinio aspekto klausimą matyti, kad didžiausiu prioritetu laikomas ekologinis pajègumas, tačiau dabartinejje situacijoje jis yra mažiausias lyginant su kitais rodikliais. Tai reikštų, kad kraštovaizdžio architektūros ir urbanistikos sprendinių sąveikos tikslai turètų būti orientuoti ị ekologinio pajègumo didinimą, kuris, akivaizdu, galètų būti susijęs su sukurtų ekosistemu vystymu, kurios yra laikomos antruoju svarbiu prioritetu. Sąveikos sprendinių optimizavimo principas reikalauja lygiavertiškai analizuoti ekologinị, socialinị ir estetinị aspektus ir sprendimų ieškoti šiuos aspektus derinant tarpusavyje. Todèl, pavyzdžiui, konkrečioje 13.4 gardelëje socialinio aspekto problematika - pasiekiamumas ir saugumas - turètų būti analizuojama ir sprendžiama siejant su ekologinio bei estetinio aspekto probleminiais klausimais.

\subsection{Antrojo skyriaus išvados}

1. Tyrimo metu nustatyta, kad teritorijų planavimo procese kuriami urbanistinių ir kraštovaizdžio architektūros sprendinių sąveikos pagrindai ir programuojama tolesne bendradarbiavimo seka ir prioritetai. Siekiant integralumo miesto teritorijose gamtinio karkaso lokalizavimo ir projektavimo procesas turi aprèpti gamtinių ir urbanistinių struktūrų sandus, kurių sąveika analizuotina pagal išskirtus tris gamtinio karkaso mieste prioritetus: ekologinio kompensavimo, socialiai orientuotos rekreacinès paskirties ir architektūrinio kompozicinio (estetinio poveikio) vaidmens. Tyrimas rodo, kad Lietuvos miestų bendrųjų planų rengejjai turi visas teisines priemones ir galimybes žaliają infrastruktūrą ir želdynų sistemą planuoti, abipusiai sprendinius siejant su kitomis bendrojo plano temomis ir taip numatant urbanistinių ir kraštovaizdžio architektūros sprendinių sąveikos ir abiejų sričių profesionalų kūrybinio bendradarbiavimo galimybes kituose planavimo ar projektavimo lygmenyse.

2. Tyrimas atskleide, kad visuose analizuotuose miestų bendruosiuose planuose yra numatyta uždavinių susijusių su kraštovaizdžio architektūros profesine veikla ir kompetencijomis. Tačiau nė viename bendrajame plane neužsimenama apie galimybę ar poreikị taikyti kraštovaizdžio architektūros principus ir priemones konkretiems uždaviniams spręsti. Siekiant tvaraus miesto tikslų būtina iš anksto numatyti miesto vystymo uždavinius, kuriems spręsti reikès kraštovaizdžio architektūros kompetencijų, metodų ir priemonių. Bendrųjų planų tyrimas išryškino kraštovaizdžio architektūros ir urbanistikos sprendinių optimalios sąveikos kriterijus miesto lygmenyje - teritorijų ekologinio pajėgumo, žaliujų erdvių vientisumo, sistemiškumo kriterijus, socialiniu aspektu - pasiekiamumo, integracijos, funkcijų sinergijos, estetiniu aspektu - esminių miesto vertybių apsaugą, metodinius estetinių poreikių kodavimus. Tik bendrojo plano sprendiniais 
galima nustatyti miesto plètros prioritetus ir užtikrinti ekologinių, socialinių ir estetinių kriterijų integralaus sinerginio veikimo pagrindus.

3. Ekspertų apklausos tyrimo rezultatai parodè, kad kraštovaizdžio architektūros objektui visos respondentų grupès vienareikšmiškai priskiria želdynų sistemą, o tai atskleidžia kraštovaizdžio architektūros svarbą ịvairiuose miesto kūrimo etapuose: pradedant miesto planavimu, kur želdynų sistema „užgimsta““ konceptualiai, toliau - urbanistiniame projektavime, kur želdynų sistema konkrečiais urbanistiniais sprendiniais yra integruojama $\mathfrak{i}$ kvartalus, jai suteikiamas konkretus pavidalas, nustatomi funkciniai prioritetai, ribos ir pan. Ekspertai pripažista kraštovaizdžio architektūros principų ir kūrybinių priemonių reikšmingumą tvaraus miesto procesuose: gamtinių išteklių taupyme ir panaudojime; prioritetų nustatyme vertinant esamą situaciją; degradavusių teritorijų atkūrime; tvarioje vandentvarkoje. Bendri apklausos rezultatai patvirtino prielaidą, kad kraštovaizdžio architektūros ir urbanistikos sprendinių sąveika turètų būti nagrinejjama tvarumo paradigmos šviesoje, derinant tarpusavyje ekologinius, socialinius ir estetinius prioritetus ir kriterijus.

4. Visi miesto vystymo procesai vyksta kraštovaizdžio kontekste. Kiekvienas urbanistinis sprendinys keičia kraštovaizdį ir turi neišvengiamą sąlytį su gamtiniu pagrindu, kuris dažnai lemia miesto ar jo dalies charakterį. Miesto raiškai daugiausia reikšmès turi reljefas, vandens telkiniai ir želdiniai. Gamtinių ir urbanistinių struktūrų dermès paieškos yra kraštovaizdžio architektūros veiklos laukas ir terpe kraštovaizdžio architektūros ir urbanistikos sprendinių sąveikai vykti. Sąveikos analizei pritaikyti miesto struktūros suvokimo elementai takai, mazgai, ribos, vietoženkliai, kvartalai - pasiteisino, nes jie gerai atspindi charakteringas gamtinių ir antropogeninių struktūrų sąveikos apraiškos vietas, leidžia sistemingai ir integraliai pažvelgti i analizuojamos teritorijos urbanistini audinị.

5. Vadovaujantis tvarumo paradigma, ekologine etika ir optimalumo logika, sukurta trinarė kraštovaizdžio architektūros ir urbanistikos sprendinių ir sąveikos vertinimo kriterijų sistema, susidedanti iš ekologinių, socialinių ir estetinių kriterijų grupių. Ekologinė kriterijų grupe aprejpia gamtinius išteklius ir tvarų jų panaudojimą, socialiniai kriterijai apima žmonių poreikius ir kokybiškų paslaugų kūrimą, estetiniai kriterijai padeda apsispręsti dèl kompozicinių priemonių atitinkamam emociniam poveikiui sukurti. Ta pati kriterijų sistema naudojama teritorijos vertinimui, prioritetų nustatymui ir kraštovaizdžio tvarkymo programų kūrimui. Atliekamo vertinimo tikslas yra išryškinti teritorijos ypatybes - stipriąsias ir silpnąsias puses, kad būtų galima priimti sprendimus, kaip stiprinti silpnąsias pozicijas, nesilpninant stipriųų.

6. Taikant erdvinių gardelių tinklo metodą buvo patikrintas kraštovaizdžio architektūros ir urbanistikos sprendinių sąveikos tyrimo modelis. Erdvinès gardelès metodas suponuoja kontekstualų požiūrị i n nagrinèjamą teritoriją. Suskai- 
dant teritoriją ị apibrèžtus teritorinius vienetus išryškèja būdingi gamtinių ir urbanistinių struktūrų fizinès bei socialinès sąveikos bruožai. Tyrimo rezultatai parodo didelius verčių skirtumus tarp visiškai šalia esančių teritorijų. Vadovaujantis kriterijų sistema, gardelei būdinga sąveikos specifika gali būti lyginama su gretimos gardelès ypatumais, ieškoma reikalingų ekologinių, socialinių ir estetinių sąsajų.

7. Taikant daugiakriterinès analizès analitinès hierarchijos proceso (AHP) metodą nustatoma optimali prioritetinių kriterijų eilè. Rezultatai palyginami su teritorijos esamos būklès ekspertinio vertinimo rezultatais. Tyrimo rezultatų interpretacijos požiūriu įdomiausios ir aktualiausios yra didžiausių nesutapimų tarp esamos situacijos vertinimo ir poreikių prioritetu vietos, kurios iš esmés parodo prioritetinių veiklų kryptị. Tyrimo metodiniame modelyje sąveikos sprendinių optimizavimo principas reikalauja lygiavertiškai analizuoti ekologini, socialinị ir estetinị prioritetus ir sprendimų ieškoti šiuos aspektus derinant tarpusavyje. 



\section{Kraštovaizdžio architektūros ir urbanistikos sprendinių sąveikos optimizavimo metodinis modelis}

Šiame skyriuje pateikiama atliktų tyrimų rezultatų interpretacija ir sintezè. Jie konceptualizuojami taikant kraštovaizdžio architektūros metodus, principus ir priemones. Aptariamas kraštovaizdžio architektūros ir urbanistikos sprendinių sąveikos optimizavizamo metodinio modelio taikymas įvairiuose teritoriniuose lygmenyse bei jo taikymo sąlygos moksle ir praktikoje. Šio skyriaus medžiaga paskelbta vienoje autorès publikacijoje (Deveikienė 2018).

\subsection{Kraštovaizdžio architektūros principai sąveikos tyrimo rezultatams konceptualizuoti}

Tyrimas atskleidè, kad visuose analizuotuose bendruosiuose planuose yra numatyta uždavinių dèl gamtinio karkaso lokalizavimo, želdynų sistemos vystymo, kraštovaizdžio formavimo, kurie iš esmès yra susiję su kraštovaizdžio architektūros profesine veikla ir kompetencijomis. Tačiau nè vienas išnagrinètas bendrasis planas nekalba apie galimybę ar poreikį taikyti kraštovaizdžio architektūros principus ir priemones konkretiems uždaviniams spręsti. Bendrujų planų tyrimas 
išryškino kraštovaizdžio architektūros ir urbanistikos sąveikos optimizavimo kriterijus miesto lygmenyje - teritorijų ekologinio pajègumo, žaliujų erdvių vientisumo, sistemiškumo kriterijus, socialiniu aspektu - pasiekiamumo, integracijos, funkcijų sinergijos, estetiniu aspektu - esminių miesto vertybių apsaugą, metodinius estetiniu poreikių kodavimus. Tik bendrojo plano sprendiniais galima nustatyti miesto miesto raidos prioritetus ir užtikrinti ekologinių, socialinių ir estetinių kriterijų integralaus sinerginio veikimo pagrindus. Mokslinès literatūros analizė ir ekspertų apklausos rezultatai parodè, kad didžiajai daliai gamtinių ir urbanistinių struktūrų sąveikos optimizavimui, sistemingam gyvenamos aplinkos kokybės užtikrinimui labai tinkami yra kraštovaizdžio architektūros principai ir priemonès. Visi urbanistiniai procesai vyksta kraštovaizdžio kontekste ir yra neišvengiamai susiję su gamtiniu pagrindu. Kiekvienas urbanistinis sprendinys keičia kraštovaizdi ir nusistovèjusius gamtinius bei socialinius procesus, todèl miesto raidos ir vystymo klausimai turètų būti analizuojami ir sprendžiami per kraštovaizdžio prizmę bei gamtinių ir antropogeninių procesų sąsajas. Kraštovaizdžio architektūra pagal savo kompetencijas sprendžia miesto, kvartalo ar objekto dermès su gamta klausimus, todèl kiekvienas urbanistinis ar architektūrinis reiškinys, susijęs su gamtiniu pagrindu ar atskirais gamtiniais elementais yra potencialus kraštovaizdžio architektūros kūrybinès veiklos objektas. Taikant kraštovaizdžio architektūros metodus ir principus miesto tvarkyme pasiekiami optimalūs gamtinių ir urbanistinių struktūrų sąveikos rezultatai.

Miesto mastu kraštovaizdžio architektūros principai ir priemonès reikšmingi kuriant daugiaplanes perspektyvas, panoramas, formuojant miesto siluetą ir atviras erdves. Kraštovaizdžio architektūros ir urbanistikos sprendinių sąveikos harmonija pasiekiama kompozicijos darna; funkciniu ir estetiniu susietumu; proporcijomis ir stiliaus vientisumu. Kraštovaizdžio architektūros kūrybos objektų socialinė reikšmė yra ta, kad jų pagalba gerinamos sąlygos fizinei ir dvasinei rekreacijai; kuriama sveika ir humaniška aplinka; išryškinamas ir formuojamas vietos identitetas, sudaromos sąlygos bendruomenès saviraiškai. Pagrindiniais kraštovaizdžio architektūros principais atliktos apklausos ekspertai pripažino šias analitines ir kūrybines veiklas: sisteminè teritorijos analizé; gamtinių ir antropogeninių procesų analizė ir kūrimas; atvirų erdvių nuoseklios sekos nustatymas ir kūrimas.

Aplinkos emocinis efektas ir estetinis poveikis pasiekiamas šiomis penkiomis svarbiausiomis kraštovaizdžio architektūros priemonėmis: kontrasto tarp gyvosios gamtos ir statinių principu; atvirų ir uždarų erdvių kaita; vaizdų kaitos dinamika; šviesos, spalvų ir formų kaita laike; horizonto linijos ir jos kaitos efektų kūrimu. Kraštovaizdžio architektūros ir urbanistikos sąveika reikšminga šiuose tvaraus miesto aspektuose - vietinių augalų ir natūralių medžiagų panaudojimas; tvarūs vandentvarkos sprendiniai; regionalumas; kompleksiškumas. Kuriant tvarų miestą, kraštovaizdžio architektūros principai ir priemonès svar- 
biausiais pripažįstami šiose veiklose: gamtinių išteklių taupymas ir panaudojimas; prioritetų nustatymas vertinant esamą situaciją; degradavusių teritorijų atkūrimas; tvari vandentvarka. Vadovaujantis šiais kūrybiniais principais ir priemonėmis kuriamas rezultatas, stiprinantis kraštovaizdžio architektūros ir urbanistikos sprendinių sąveiką pagal išsikeltus tvarumo kriterijus, jungiant tarpusavyje ekologinị, socialinị ir estetinị pradą (3.1 lentelè).

3.1 lentelè. Tyrime taikomų kriterijų ir kraštovaizdžio architektūros principų bei priemonių dermès analizè. V. Deveikienè, 2018

Table 3.1. Analysis of the consistency of the criteria used in the study and the principles and measures of landscape architecture. By V. Deveikiené, 2018

\begin{tabular}{|c|c|c|c|}
\hline & Estetiniai & Ekologiniai & Socialiniai \\
\hline $\begin{array}{l}\text { Tyrimui } \\
\text { pasirinkti } \\
\text { kriterijai }\end{array}$ & $\begin{array}{l}\text { Nuoseklumas } \\
\text { Skaitomumas } \\
\text { Sudėtingumas } \\
\text { Paslaptingumas }\end{array}$ & $\begin{array}{l}\text { Natūralumas } \\
\text { Bioįvairovė } \\
\text { Ekologinis pajėgumas } \\
\text { Sukurtos ekosistemos }\end{array}$ & $\begin{array}{l}\text { Pasiekiamumas } \\
\text { Saugumas } \\
\text { Socialinè } \\
\text { itrauktis } \\
\text { Funkcijų pasida- } \\
\text { lijimas }\end{array}$ \\
\hline \multicolumn{4}{|c|}{ Kraštovaizdžio architektūros principų ir priemonių raiška mieste } \\
\hline Principai & $\begin{array}{l}\text { Estetinis-emocinis } \\
\text { efektas }\end{array}$ & $\begin{array}{l}\text { Tvaraus miesto } \\
\text { kūrimas }\end{array}$ & $\begin{array}{l}\text { Socialinis } \\
\text { efektas }\end{array}$ \\
\hline $\begin{array}{l}\text { Sisteminè teri- } \\
\text { torijos analizė }\end{array}$ & $\begin{array}{l}\text { Daugiaplanės per- } \\
\text { spektyvos; miesto } \\
\text { siluetas; panoramos }\end{array}$ & $\begin{array}{l}\text { Regionalumas; } \\
\text { kompleksiškumas }\end{array}$ & Vietos identitetas \\
\hline \multirow{2}{*}{$\begin{array}{l}\text { Gamtinių ir } \\
\text { antropogeninių } \\
\text { procesų anali- } \\
\text { zè ir kūrimas }\end{array}$} & $\begin{array}{l}\text { Kontrastas tarp gy- } \\
\text { vosios gamtos ir } \\
\text { statinių }\end{array}$ & $\begin{array}{l}\text { Vietinių augalų ir natū- } \\
\text { ralių medžiagų panau- } \\
\text { dojimas }\end{array}$ & $\begin{array}{l}\text { Fizinė ir dvasinè } \\
\text { rekreacija }\end{array}$ \\
\hline & $\begin{array}{l}\text { Šviesos, spalvų ir } \\
\text { formų kaita laike }\end{array}$ & $\begin{array}{l}\text { Gamtinių išteklių tau- } \\
\text { pymas ir panaudojimas }\end{array}$ & Sveika aplinka \\
\hline \multirow{3}{*}{$\begin{array}{l}\text { Atvirų erdvių } \\
\text { nuoseklios } \\
\text { sekos nusta- } \\
\text { tymas ir kūri- } \\
\text { mas }\end{array}$} & $\begin{array}{l}\text { Horizonto linija ir } \\
\text { jos kaitos efektai }\end{array}$ & $\begin{array}{l}\text { Degradavusių teritorijų } \\
\text { atkūrimas }\end{array}$ & $\begin{array}{l}\text { Humaniška ap- } \\
\text { linka }\end{array}$ \\
\hline & $\begin{array}{l}\text { Atvirų ir uždarų } \\
\text { erdvių kaita }\end{array}$ & \multirow[t]{2}{*}{ Tvari vandentvarka } & \multirow[t]{2}{*}{$\begin{array}{l}\text { Bendruomenès } \\
\text { saviraiška }\end{array}$} \\
\hline & $\begin{array}{l}\text { Vaizdų kaitos di- } \\
\text { namika }\end{array}$ & & \\
\hline
\end{tabular}


Kraštovaizdžio architektūra yra išskirtinė akademinė disciplina ir praktinė veikla, kuri telkia projektuotojų kompetencijas, leidžiančias imtis uždavinių racionaliai ir kūrybiškai sujungti gamtinius ir urbanistinius procesus įvairiose planavimo ir projektavimo stadijose. Taikant kraštovaizdžio architektūros tyrimo ir kūrybos metodus, principus ir priemones miesto ekologiniai, estetiniai ir socialiniai poreikiai optimaliai suderinami ir sprendžiami sujungiant juos ị vieningą tvarią sistemą, veikiančią laike, generuojančią nuolatinius gamtinius bei socialinius procesus, užtikrinančią optimalią sąveiką tarp kraštovaizdžio architektūros ir urbanistikos sprendinių bei veiksmų. Kaip teigia J. Corner (2006), kraštovaizdžio architektūros principai yra svarbūs tuo, kad jais vadovaujantis:

1. Sukuriamas procesas laike (angl. processes over time). Tai laike besitęsiantys, tarpusavyje susiję biotiniai ir abiotiniai procesai, sujungiantys gamtos galią ir socialinius bei kultūrinius veiksmus. Dèl pritaikytų kraštovaizdžio architektūros principų gamtiniai procesai tampa kultūros ir identiteto dalimi. Tai liudija gamtos ir kultūros paveldo objektai - dvarų ir pilių ansambliai su įstabiais parkais ir supančiais kraštovaizdžiais.

2. Issisavinami paviršiai (angl. the staging of surfaces). Kūrybiškai sutvarkomi, išeksponuojami ir ,idarbinami“ visi teritorijos paviršiai. Nuosekliai taikant kraštovaizdžio architektūros principus ir priemones ị vieningai veikiančią sistemą sujungiami žemés plotai, apželdinti stogai, terasos, netgi pastatų sienos ir kitos konstrukcijos.

3. Pasiūlomi veiklos ar darbo metodai (angl. the operational or working method). Iveiklinama tiek pati teritorija, tiek sukuriama veikla sąveikos proceso subjektams. Kraštovaizdžiai ,idarbinami“ - gerinama gyvenimo aplinka, valomas oras, vanduo, gruntas. Suteikiama sveika aplinka ir pozityvi energija žmogui. Kraštovaizdis kuria pridètinę vertę nekilnojamajam turtui. Generuojamos žmonių veiklos - sportas, bendravimas, bendras sodininkavimas.

4. Vaizduotès (angl. the imaginary) pagalba sukuriama emociškai patraukli aplinka. Didinamas susidomejimas ir pasididžiavimas savo aplinka. Vaizduotès pagalba kuriami techniniai ir ekologiniai sprendiniai igauna estetini pavidalą, tampa meno kūrinio dalimi. Tuo pačiu yra patraukliai ir iškalbingai perteikiami tvarumo vertybiniai aspektai. Vaizduote padeda sukurti įspūdingas kompozicijas panaudojant turimus gamtinius ir žmogaus kūrybos išteklius.

Prancūzų mokslininkas S. Marot (1995), yra išgryninęs keturis kraštovaizdžio architektūros principus, dar kitaip vadinamus metodus (Marot 1995; Jauslin 2010). Konceptualizuojant rezultatus, šie principai yra naudingi tuo, kad jie sudaro galimybes visus prioritetinius uždavinius spręsti vienu metu, sąveikos tyrimo sprendinius sujungiant ị vieną visumą:

1. Anamnezè - tai skirtingų laikmečių informacijos kaupimas ir analizé, ateinant prie dabartinio kraštovaizdžio būklès, kai tiriant esamo kraštovaizdžio situaciją integruojami istoriškai susiklostę veiksniai - nuo natūralios iki sukurtos 
gamtos, apimant visuomenès dvasinị ir simbolių lygmenị. Visų tipų kraštovaizdžiai matomi kaip įvairiasluoksnis palimpsestas - gamtinis, kultūrinis, infrastruktūros ar užstatytas.

2. Procesas - šiuo principu pagrindžiama natūralių ir paskatintų kraštovaizdžio pokyčių dinamika. Vietos plètojimo kuria nors kryptimi procesą lemia gamtos ir laiko efektas, o taip pat ir projektavimo strategija. Kūrybinis procesas apima stebejjimą, apsaugą ir socialinių bei ekologinių sistemų valdymą. Kraštovaizdžio architektas struktūrizuoja potencialų kraštovaizdį, puikiai žinodamas, kad jo darbas niekada nebus baigtas kaip statinys.

3. Erdvinis sekvenavimas - taikant ši principą yra nustatoma erdvių seka, kai viena erdvė papildo kitą, paruošia naujiems ǐspūdžiams kitoje erdvèje. Erdvinis nuoseklumas yra labai svarbus kraštovaizdžio projektavimo metodas. Kraštovaizdžio erdvinès savybès yra labai dinamiškos ir iš esmès skiriasi nuo pastatų architektūrai būdingų statiškų erdvinių savybių. Tokios sritys, kaip topografija (reljefas), judejimas ir horizontas, bei vaizdingumas yra susiję su erdviniu sekvenavimu.

4. Kontekstas - tai svarbus ir išskirtinai kraštovaizdžio architektūrai būdingas principas. Kraštovaizdžio projektas kuria kontekstą, o ne tik reaguoja i jị. Konteksto kūryba susideda iš intensyvių funkcijos, vaizdo ir erdvès santykių ir jų įvairiapusių kombinacijų, atskirus elementus sujungiant ị bendrą kompoziciją. Kraštovaizdžio architektūrai būdinga ypatybe iš kraštovaizdžio formos ir konteksto kurti programą. Konteksto principas ịpareigoja žvelgti toliau projektui arba analizei apibrèžtų ribų.

Harvardo universiteto (JAV) mokslininkė J. Desimini (2013) apibendrindama kraštovaizdžio privalumus, teigia, kad kraštovaizdis yra neišvengiamas (angl. Landscapes are inevitable) - netgi nieko nedarant, kraštovaizdis atsikuria net labiausiai užstatytose teritorijose. Tai liudija daugybè nuosekliai ,augančių“ kraštovaizdžiu visuose miestuose. Kraštovaizdis yra nebrangus (angl. Landscapes are cheap) - ypač palyginti su pilkaja infrastruktūra ar kitomis miestų plètros formomis. Kraštovaizdis sugeba prisitaikyti ir keistis esant skirtingoms sąlygoms - siekiant jo tvarumo nustatomi lankstūs reikalavimai jo priežiūros intensyvumui. Kraštovaizdị formuojančios teritorijos gali būti tvarkomos ịvairiais būdais, todèl bendruomenè, vietiniai sodininkai ir miškininkai gali tapti viešosios erdvès prižiūrètojais ir globejjais. Kraštovaizdis yra produktyvus ir daugiafunkcinis (angl. Landscapes are productive and multi-functional). Jie valo orą, vandenị ir dirvožemị, jie daro miesto aplinką sveikesnę, jie teikia išteklius maistui, energijai, prekybai ir buveinèms. Taip jie ugdo naujus miesto kraštovaizdžius, naujas miestiečių patirtis ir tampa pagrindu daugybei socialinių veiklų ir santykių. Kraštovaizdžiai padeda kurti bendruomenes, jie gali būti mokymosi ir darbo vieta, o taip jie gali būti ekonomiškai našūs. Kraštovaizdis yra veiksmingas tyrimo ir eksperimentavimo pagrindas (angl. Landscapes are effective 
grounds for research and experimentation). Tai vietos, kuriose gali būti saugiai ir veiksmingai išbandomos naujos idèjos, kad vèliau būtų galima naudoti visame mieste ir kituose miestuose. Pavyzdžiui, plataus masto užteršto miesto dirvožemio sluoksnių išvalymo naujo būdo patikrinimas. Kraštovaizdis yra ,žalias“" (angl. Landscapes are green). Tinkamai ịrengti, kraštovaizdžiai sumažina miesto išlaidas - pavyzdžiui, lietaus vandenị infiltruojantys sodai, vietoj kietų dangų, vamzdynų ir valymo ịrenginių. Jie taip pat sukuria sodrų, turtingą miesto ịvaizdị ir formuoja jo identitetą, ko norètųsi kiekvieno miesto konkurencingumui. Kraštovaizdžio sistemos efektyviausios dideliuose masteliuose (angl. Landscape systems work most effectively across large scales) - ypač regionuose. Kraštovaizdžiai sugeba sujungti ir suderinti iš pažiūros visiškai nesusijusius objektus.. Tokie kraštovaizdžiai turi galios kurti miestus ir regionus. Kraštovaizdis praturtina (angl. Landscapes are enriching) - jis kuria sveiką aplinką žmonèms, kurie juo naudojasi, daro pozityvų kognityvinị ir vizualini poveikị. Kraštovaizdis taupo laiką (angl. Landscapes buy time) - jis keičiasi ir vystosi savarankiškai. Tačiau jis taip pat gali būti naudojamas laikiniems poreikiams, kol bus priimti kiti sprendimai dèl vietovès ar kaimynijos ateities.

Vilniaus miesto teritorijų tyrimo metu nustyta, kad dideli tarpusavio kriterijų grupių skirtumai pasireiškia išskirtinai gardelèje dominuojant gamtiniams arba urbanistiniams elementams (3.2 lentelè).

3.2 lentelè. Ryškiausius verčių skirtumus turinčios gardelès. V. Deveikienè, 2018 Table 3.2. The example of grids with the bigest marge of values. V. Deveikiene, 2018

\begin{tabular}{|c|c|c|c|c|c|}
\hline \multicolumn{3}{|c|}{ Vertinimo kriterijų aspektai } & \multicolumn{3}{|c|}{ Vertinimo kriterijų aspektai } \\
\hline Ekologinis & Socialinis & Estetinis & Ekologinis & Socialinis & Estetinis \\
\hline \multicolumn{3}{|c|}{ Vertinimas balais ir santykinè vertè } & \multicolumn{3}{|c|}{ Vertinimas balais ir santykinè vertè } \\
\hline 161 & 78 & 77 & 49 & 211 & 198 \\
\hline 0,53 & 0,26 & 0,25 & 0,16 & 0,70 & 0,66 \\
\hline a & & & & & 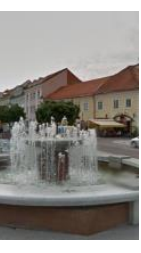 \\
\hline
\end{tabular}

Metodiniame tyrimo modelyje, nors ir skatinama siekti visų trijų tvarumo aspektu sinergijos, bet taip pat laikomasi principo atskleisti esamas teritorijos ypatybes. Tai yra - ryškinti būdingus vertingiausius bruožus, palaipsniui ịveikiant ir stiprinant silpnąsias sąveikos puses. Désningumas yra tas, kad ten, kur 
yra daugiau gamtinių elementų, dažniausiai fiksuojama ne tik aukštesnè ekologinè sąveikos vertè, bet ir atitinkamai kitos vertès. Tarkim, aukšta ekologinio aspekto sąveikos verte turi pozityvios įtakos ir estetinèms bei socialinėmis vertèms. Pozityvios įtakos visoms trims verčiu grupėms turi atitinkamu laikotarpiu tikslingai kurtas kraštovaizdis - sodinti želdiniai, formuotas reljefas, nutiesti takai, sukurtos funkcinès ir vizualinès sąsajos. Atvirkštinis rezultatas pastebimas, ten, kur nebuvo dèta pastangų kurti gyvybingą aplinką. Išnagrinèjus tyrimo metu gautų verčių dėsningumus, apsispręsta ieškoti sąsajų tarp nustatytų gamtinių ir urbanistinių elementų sąveikos verčių ir kraštovaizdžio architektūros ir urbanistikos sprendinių sąveikos aktyvumo laipsnio. Sudarytos keturios sąveikos aktyvumo grupès (3.3 lentelè).

3.3 lentelè. Sąveikos aktyvumo išraiška tyrimo metu nustatytų verčiu pagrindu ir sąveikos aktyvumo rodikliai. Šaltinis: V. Deveikienè, 2018

Table 3.3. The expression of the activity of the interaction based on the values defined in the study and the indicators of interaction activity. Source: V. Deveikiené, 2018

\begin{tabular}{|c|c|c|c|c|}
\hline \multirow{6}{*}{ 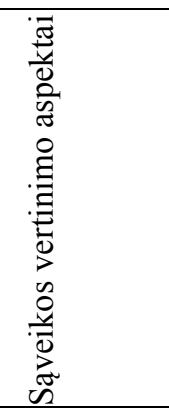 } & \multicolumn{4}{|c|}{ Sąveikos aktyvumo forma } \\
\hline & $\begin{array}{l}\text { Aktyvi } \\
\text { sąveika }\end{array}$ & $\begin{array}{l}\text { Nuosaiki } \\
\text { sąveika }\end{array}$ & $\begin{array}{l}\text { Pasyvi } \\
\text { sąveika }\end{array}$ & $\begin{array}{l}\text { Destruktyvi } \\
\text { sąveika }\end{array}$ \\
\hline & \multicolumn{4}{|c|}{ Sąveikos vertinimas balais kriterijų grupèje } \\
\hline & $300-150$ & $149-75$ & $74-42$ & $41-1$ \\
\hline & \multicolumn{4}{|c|}{ Santykinè sąveikos vertè } \\
\hline & $1-0,5$ & $0,49-0,25$ & $0,24-0,14$ & $0,13-0$ \\
\hline \multicolumn{5}{|c|}{ Kriterijų grupès } \\
\hline $\begin{array}{l}\text { Ekologinis } \\
\text { aspektas }\end{array}$ & $\begin{array}{l}\text { Sistemiškas } \\
\text { saugojimas ir } \\
\text { kūrimas }\end{array}$ & $\begin{array}{l}\text { Fragmentiškas } \\
\text { kūrimas }\end{array}$ & Ignoravimas & $\begin{array}{l}\text { Naikinantys } \\
\text { arba ardantys } \\
\text { veiksmai }\end{array}$ \\
\hline $\begin{array}{l}\text { Socialinis } \\
\text { aspektas }\end{array}$ & $\begin{array}{l}\text { Visų proceso } \\
\text { dalyviu ben- } \\
\text { dradarbiavimas }\end{array}$ & $\begin{array}{l}\text { Atskirų suinte- } \\
\text { resuotu grupių } \\
\text { veiksmai }\end{array}$ & $\begin{array}{l}\text { Vienpusiški } \\
\text { veiksmai }\end{array}$ & $\begin{array}{l}\text { Visuomenės } \\
\text { interesų apribo- } \\
\text { jimai }\end{array}$ \\
\hline $\begin{array}{l}\text { Estetinis } \\
\text { aspektas }\end{array}$ & $\begin{array}{l}\text { Nuoseklus ir } \\
\text { aktyvus KA } \\
\text { dalyvavimas }\end{array}$ & $\begin{array}{l}\text { Epizodiškas } \\
\text { KA dalyvavi- } \\
\text { mas }\end{array}$ & $\begin{array}{l}\text { KA kompeten- } \\
\text { cijų ignoravi- } \\
\text { mas }\end{array}$ & $\begin{array}{l}\text { KA principu } \\
\text { blokavimas }\end{array}$ \\
\hline
\end{tabular}


Šis sąveikos aktyvumo grupių nustatymas yra grindžiamas tirtų teritorijų erdvinès raiškos pokyčių laiko tèkmèje dèsningumais. Sąveikos aktyvumo grupès nustatomos vadovaujantis prielaida, kad teritorijose, gavusiose aukštesnị gamtinių ir urbanistinių struktūrų sąveikos vertinimą, vyksta arba potencialiai galima atitinkamai aktyvesnè kraštovaizdžio architektūros ir urbanistikos sprendinių sąveika.

Nustatyti aktyvumo rodikliai leidžia apibendrinti teritorijos būklę sąveikos aktyvumo požiūriu ir pagal poreikị planuoti tolimesnius veiksmus - vadovaujantis kriterijų sistema ieškoti efektyviausių ir optimaliausių teritorijos tvarkymo būdų, taikant kraštovaizdžio architektūros principus ir priemones. Atsižvelgiant ị tai, kad vienas iš kraštovaizdžio architektūros principu yra proceso laike kūrimas (Marot 1995; Corner 2006; Jauslin 2010), buvo apsispręsta ịvesti laiko dimensiją. Tai leistų apytikriai orientuotis, per koki laikotarpi gali būti optimaliai pasiektas aplinkos gerinimo uždavinys. Atsižvelgiant ị kraštovaizdžio architektūros kūrinių nuolatinès kaitos savybę, daroma prielaida, kad dalis ekologinio, socialinio ir estetinio efekto yra pasiekiama nieko nedarant, t. y. teisingai ir laiku suformavus gyvenamają aplinką, toliau kraštovaizdi , ,augina“" laikas.

Kraštovaizdžio architektūros ir urbanistikos sprendinių sąveikos aktyvumo laipsnio ir vertės augimo laike santykis nagrinètas gyvenamųu rajonų (šiaurinè Vilniaus miesto teritorija), statytų apie 1980-1990 metus vertinimo rezultatų analizès pagrindu. Gyvenamasis mikrorajonas buvo statomas buvusiose agrarinėse teritorijose, išsaugant tik reikšmingesnius miško plotus ir su jais susijusị reljefą. Didžioji dalis mikrorajono statyta vadinamojoje tuščioje vietoje - visa tai, ką turime, daugiausia yra sukurta maždaug prieš 25-30 metų.

Gamtinių struktūrų, ypač želdinių, ekologinès, o kartu ir estetinès savybès ryškèja laikui bėgant. Tyrimas rodo, kad prieš 30 metų statytose ir apželdintose teritorijose estetinę vertę kuria tinkamai susodintų ir prižiūrètų želdinių kompozicijos. Vaizdai yra stipresni ten, kur tinkamai panaudotas ar išraiškingai suformuotas reljefas. Tiek nekilnojamojo turto ekspertai, tiek kiti specialistai, nagrinèjantys gyvenamosios aplinkos kokybę, pripažista, kad senujų, arba vadinamujų tarybinių, mikrorajonų privalumas yra erdvios ir žalios teritorijos prie pat namų. Želdinių raidai, o tuo pačiu ir visos ekosistemos formavimuisi yra būdingas periodiškumas, kai ji pereina iš vienos stadijos i kitą. Pirmieji trejipenkeri metai yra želdinių žemutinio ardo (daugiamečių žolinių augalų ir krūmų) ịsitvirtinimo laikotarpis, kurio metu jau užgimsta nesudètinga ekosistema. Penktais-dešimtais metais aukštesnio ir žemesnio ardo (medžių ir krūmų) želdiniai igauna jų santykiui būdingas proporcijas. Dešimtais-penkioliktais metais medžiai jau pajègūs formuoti erdvę, ị aukštesnę pakopą pereina ekosistema. Pavieniai medžiai ar jų grupès urbanistinejje aplinkoje erdvinio formanto pozicijas igauna tik dvidešimtais-dvidešimt penktais metais po jų pasodinimo. Tokie medžiai jau pajègūs atlikti urboekologines funkcijas. 
Kraštovaizdžio, kaip savarankiškai laike besivystančio gyvo organizmo, samprata yra labai svarbi kraštovaizdžio architektūros ir urbanistikos sprendinių optimizavimo postulatams. Pirmiausia, tai patvirtina, kad naudinga maksimaliai išsaugoti gamtinius elementus, nes naujai suformuoto kraštovaizdžio ekologinis, socialinis ir estetinis efektas bus pasiektas tik po 20-30 metų. Kraštovaizdžio architektūros ir urbanistikos sprendinių sąveikos aktyvumo augimo preliminaraus apskaičiavimo idejja, iškelta šiame moksliniame darbe, yra tik prielaida tolimesniems moksliniams tarpdisciplininiams tyrimams, apimantiems tiek ekonomikos, tiek ekologijos, kraštovaizdžio architektūros ir urbanistikos mokslus. Vadovaujantis gamtinių elementų ir ekosistemų cikliškumo principais, kraštovaizdžio architektūros ir urbanistikos sprendinių sąveikos aktyvumo augimo laiko bėgyje skalè suskirstyta ị penkerių metų laikotarpius.

Nuoseklaus kraštovaizdžio architektūros ir urbanistikos sprendinių sąveikos verčių augimo grafinè išraiška pateikiama $\mathrm{C}$ priedo $\mathrm{C} 1$ paveiksle. Vadovaujantis kraštovaizdžio architektūros principu kurti procesus laike, pateikiama schema, kaip daugiakriterinès analizès būdu nustatytos teritorijos tvarkymo prioritetiniai kriterijai evoliucionuoja laike ir palaipsniui augina likusių kriterijų vertes (3.1 pav.).

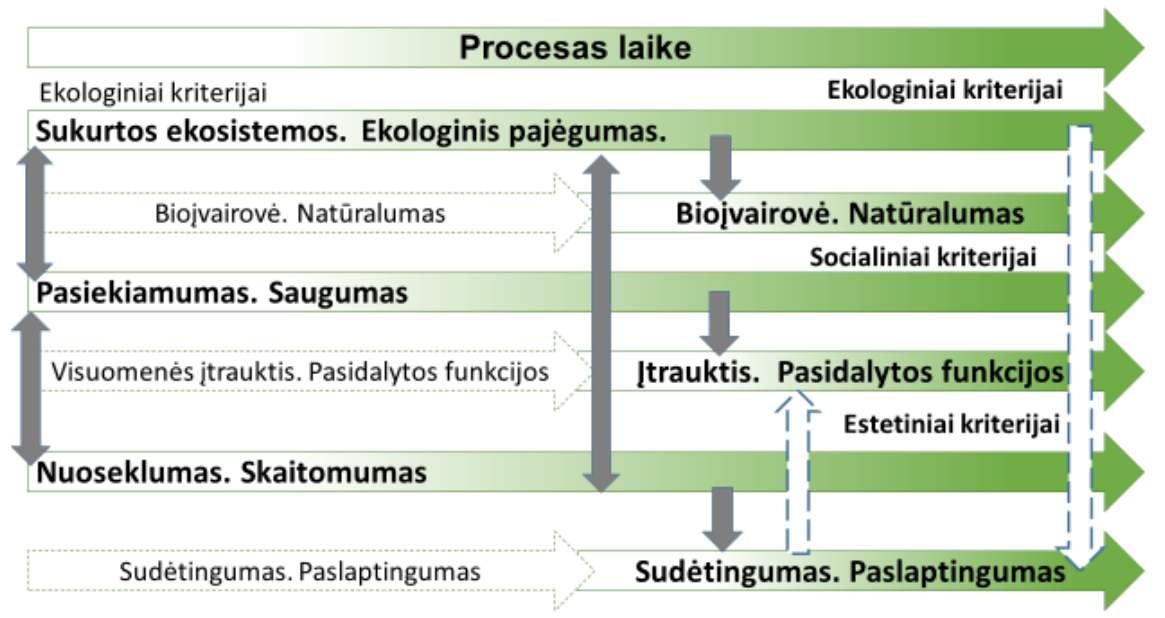

3.1 pav. Nuoseklaus kraštovaizdžio architektūros ir urbanistikos sprendinių sąveikos verčių, išreikštu per kriterijus, augimo laike grafinè išraiška.

Saltinis: V. Deveikienè, 2018

Fig. 3.1. The graphic expression of consistant development in time of values of the interaction between landscape architecture and urban solutions in terms of criteria.

Source: V. Deveikienè, 2018 
Daroma prielaida, kad tinkamai sukurta gamtinè aplinka bėgant laikui nuosekliai iggauna didesnę ekologinę vertę ir tuo pačiu kuria erdvès estetinę vertę. Šios abi vertès suponuoja socialines vertes ir yra tiesiogiai priklausomos nuo socialinio gyvenimo dalyvių nusiteikimo šias vertes kurti ir palaikyti. Tikètina, kad, tinkamai įvykdžius prioritetiniais kriterijais išsikeltus uždavinius, bėgant laikui naujas vertes pasieks ir antrinių kriterijų uždaviniai. Tarkim, prioritetiniais kriterijais atitinkamoje teritorijoje buvo nustatyta, kad ekologiniu aspektu svarbiausia yra sukurti ekosistemas ir didinti ekologini pajègumą, o bioịvairovè ir natūralumas laikomi antraeiliais uždaviniais.

3.1 paveiksle pateiktoje schemoje aptariamu atveju besivystančios sukurtos ekosistemos pasieks aukštą bioịvairovès laipsnị, o nuolat palaikant jų pajègumą ekosistemos adaptuosis aplinkoje kaip natūralios. Socialine prasme, užtikrinant sukurtu gamtinių teritorijų pasiekiamumą ir saugumą, palaipsniui didès visuomenès susidomejimas bei dalyvavimas ir funkcijų pasidalijimas. Estetine prasme, taikant kraštovaizdžio architektūros erdvių sekvenavimo principą, pirmiausia užtikrinamas nuoseklus erdvių tvarkymas, sukuriama aiškiai suvokiama erdvinė ir funkcinių ryšių kompozicija, kuriamoms ekosistemoms suteikiamas estetinis pavidalas. Laiko tėkmëje, besiformuojant ekosistemoms ir erdvinį charakteri igaunant augalų kompozicijoms, tikètina, kad teritorijoje nuolat gausės sudètingesnių ir išraiškingesnių vaizdų, kraštovaizdis įgaus paslaptingumo ir kitų emocinių savybių.

Panaši schema gali būti taikoma ir nagrinèjama ịvairiais prioritetinių kriterijų pasiskirstymo variantais. Verčių pagal kriterijus augimą laike lemia suinteresuotų veikejjų apsisprendimas dèl kraštovaizdžio architektūros ir urbanistikos sprendinių sąveikos aktyvumo laipsnio pasirinkimo ir palaikymo. Kiekvienam sąveikos aktyvumo laipsniui priskiriami indikatoriai pagal vertinimo kriterijus (C priedas, C3 lentelè).

J. Desimini savo moksliniame tyrime yra išgryninusi ir pateikusi penkis miesto kraštovaizdžio tvarkymo tipus (Desimini 2013), kurie kuria aktyvią sąveiką su urbanistiniu kontekstu. Tai yra:

a) bendruomenès atviros erdvès (angl. community open space);

b) ekologiniai kraštovaizdžiai (angl. ecological landscapes);

c) mèlynoji-žalioji infrastruktūra (angl. blue-green infrastructure);

d) produktyvūs kraštovaizdžiai (angl. productive landscapes);

e) laikini kraštovaizdžiai (angl. transitional landscapes).

Šie kraštovaizdžio tvarkymo tipai yra interpretuojami ir taikomi moksliniame darbe, siekiant sukurti universalią kraštovaizdžio tvarkymo tipologijos sistemą, susietą su kitais sąveikos optimizavimo tyrimo modelyje taikomais metodais ir principais (3.4 lentelè). 
3.4 lentelè. Metodinè kraštovaizdžio tvarkymo tipų interpretacija.

Šaltinis: V. Deveikienè, 2018

Table 3.4. The methodological interpretation of landscape management categories.

Source: V. Deveikienè, 2018

\begin{tabular}{|c|c|c|c|c|}
\hline $\begin{array}{l}\text { Bendruome- } \\
\text { nès atviros } \\
\text { erdvès }\end{array}$ & $\begin{array}{l}\text { Ekologinis } \\
\text { kraštovaizdis }\end{array}$ & $\begin{array}{l}\text { Mèlynoji- } \\
\text { žalioji } \\
\text { infrastruktūra }\end{array}$ & $\begin{array}{l}\text { Produktyvus } \\
\text { kraštovaizdis }\end{array}$ & $\begin{array}{l}\text { Pereinamasis } \\
\text { kraštovaizdis }\end{array}$ \\
\hline \multicolumn{5}{|c|}{ Kraštovaizdžio tvarkymo tipams būdingos funkcijos } \\
\hline $\begin{array}{l}\text { Rekreacija; } \\
\text { socialinis gy- } \\
\text { venimas; ne- } \\
\text { didelès apim- } \\
\text { ties maisto } \\
\text { auginimas }\end{array}$ & $\begin{array}{l}\text { Pievos ir miš- } \\
\text { kai, kuriantys } \\
\text { buveines ir } \\
\text { kitas vertybes }\end{array}$ & $\begin{array}{l}\text { Tvarios van- } \\
\text { dentvarkos ir } \\
\text { oro valymo } \\
\text { kraštovaizdis }\end{array}$ & $\begin{array}{l}\text { Generuoja } \\
\text { naujoves; } \\
\text { teikia energiją } \\
\text { bei maistą; } \\
\text { kurian naują } \\
\text { miesto patirti }\end{array}$ & $\begin{array}{l}\text { Valo gruntą; } \\
\text { kuria naujas } \\
\text { socialinės } \\
\text { raiškos formas } \\
\text { ir iniciatyvas }\end{array}$ \\
\hline \multicolumn{5}{|c|}{ Kraštovaizdžio tvarkymo tipams būdingi objektai } \\
\hline $\begin{array}{l}\text { Žaidimų aikš- } \\
\text { telè; sporto } \\
\text { aikštynai; } \\
\text { parkai; } \\
\text { aikštés; rek- } \\
\text { reaciniai cent- } \\
\text { rai; žaliosios } \\
\text { jungtys; mies- } \\
\text { to sodai; ūki- } \\
\text { ninkų turgūs; } \\
\text { kapinès }\end{array}$ & $\begin{array}{l}\text { Gamtiniai } \\
\text { parkai; } \\
\text { sukurti ekolo- } \\
\text { giniai } \\
\text { parkai; } \\
\text { miškai; } \\
\text { gamtiniai } \\
\text { keliai; upiu } \\
\text { pakrantès }\end{array}$ & $\begin{array}{l}\text { Ežerai; tven- } \\
\text { kinių siste- } \\
\text { mos; infiltra- } \\
\text { ciniai parkai; } \\
\text { apsauginès } \\
\text { želdinių juos- } \\
\text { tos; } \\
\text { apsauginiai } \\
\text { miškai }\end{array}$ & $\begin{array}{l}\text { Tyrimų lau- } \\
\text { kai; miesto } \\
\text { ūkiai; akva- } \\
\text { kultūros bioe- } \\
\text { nergijos ga- } \\
\text { vybos laukai, } \\
\text { sodybos; sto- } \\
\text { vyklavietès }\end{array}$ & $\begin{array}{l}\text { Renginių } \\
\text { kraštovaiz- } \\
\text { džiai; } \\
\text { rekultivaci- } \\
\text { niai, laukai ir } \\
\text { miškai; } \\
\text { žemės menas; } \\
\text { miesto pievos }\end{array}$ \\
\hline \multicolumn{5}{|c|}{ Kraštovaizdžio architektūros ir urbanistikos sprendinių sąveikos kriterijai } \\
\hline $\begin{array}{l}\text { Visuomenės } \\
\text { ittrauktis; sis- } \\
\text { temiškumas; } \\
\text { funkcijų pasi- } \\
\text { dalijimas; } \\
\text { erdviu nuo- } \\
\text { seklumas; } \\
\text { ekologinis } \\
\text { pajegumas; } \\
\text { kompleksiš- } \\
\text { kumas; } \\
\text { saugumas }\end{array}$ & $\begin{array}{l}\text { Natūralumo } \\
\text { išsaugojimas; } \\
\text { bioịvairové; } \\
\text { pasiekiamu- } \\
\text { mas; } \\
\text { paslaptingu- } \\
\text { mas; } \\
\text { visuomenès } \\
\text { itrauktis }\end{array}$ & $\begin{array}{l}\text { Sukurtos eko- } \\
\text { sistemos; } \\
\text { bioịvairovė; } \\
\text { visuomenės } \\
\text { ịtrauktis; } \\
\text { kompleksiš- } \\
\text { kumas; } \\
\text { integralumas; } \\
\text { paslaptingu- } \\
\text { mas } \\
\text { sudètingumas }\end{array}$ & $\begin{array}{l}\text { Sukurtos eko- } \\
\text { sistemos; } \\
\text { funkcijų pasi- } \\
\text { dalijimas; } \\
\text { skaitomumas }\end{array}$ & $\begin{array}{l}\text { Sukurtos eko- } \\
\text { sistemos; } \\
\text { visuomenès } \\
\text { ịtrauktis; } \\
\text { funkcijų pasi- } \\
\text { dalijimas; } \\
\text { skaitomumas }\end{array}$ \\
\hline
\end{tabular}


Prioritetinių uždavinių sprendimas reikalauja kompleksinio požiūrio ir sinerginio ryšio tarp įvairių gamtinių ir urbanistinių struktūrų sąveikos optimizavimo proceso dalyvių, kurie pagal veikimo pobūdị gali būti skirstomi ị penkias grupes - privatūs asmenys, visuomenè (bendruomenè), įvairaus lygmens valdžios institucijos, verslo įmonès ir jų atstovai bei profesionalai projektuotojai. Jų bendras veikimas yra sąlygojamas vieningo požiūrio į žmogaus santykị su gamta, savo veiksmus vertinant gèrio ir blogio požiūriu ir pagal šias kategorijas formuluojant savo elgesio principus (Kalenda 2005).

Kaip pastebi ekologinius, estetinius ir socialinius klausimus kraštovaizdžio architektūroje nagrinèjantis I. Thomson, aplinkos tvarkymo sprendimai yra glaudžiai susiję su žemès naudojimu ir jos nuosavybe, su privilegijuotu gyvenimo stiliumi ir noru arba nenoru ji keisti (Thompson 2000). Aplinkos arba ekologinè etika gali padèti rasti bendrą kalbą nustatant pagrindinius teritorijos tvarkymo principus. Gamtinių ir urbanistinių struktūrų sąveiką lemianti etinè visuma formuojama kiekvieno iš proceso dalyvių etikos - asmeninès etikos, verslo etikos, profesinès etikos ir ekologinès etikos. Nuo kiekvieno iš proceso dalyvių priklauso, ar bus savalaikiškai ir visavertiškai pasitelkti kraštovaizdžio architektūros principai ir metodai teritorijos prioritetiniams uždaviniams spręsti. Kaip taikant keturis pagrindinius kraštovaizdžio architektūros principus ir igyvendinant prioritetinius uždavinius dalyvauja gamtinių ir urbanistinių struktūrų sąveikos proceso dalyviai, pateikiama $\mathrm{C}$ priedo $\mathrm{C} 4$ lentelèje.

Kuriamame kraštovaizdžio architektūros ir urbanistikos sprendinių sąveikos optimizavimo metodiniame modelyje numatomi trys pagrindiniai veiksmų etapai. Jie apima tris pagrindinius teritorijos tyrimo ir analizès etapus - vertinimą, prioritetų nustatymą ir tolimesnių veiksmų programos sukūrimą.

Vertinimo etapu atskleidžiamos teritorijos stipriosios ir probleminès pusès ekologinių, socialinių ir estetinių kriterijų atžvilgiu. Prioritetų nustatymo etapu formuojamas veiksmų vertybinis pagrindas, susitariama dèl veiklų pobūdžio ir krypčių, apsisprendžiama dẻl uždaviniams spręsti reikalingų kompetencijų. Veiksmų programos kūrimo etape pasirenkamas kraštovaizdžio tvarkymo tipas, kuris sąlygoja kraštovaizdžio architektūros ir urbanistikos sprendinių sąveikos pobūdi, proceso dalyvius, reikalingus atlikti integralius veiksmus.

Vertinimo, prioritetų ir programos kūrimo etapai yra aktualūs visuose miesto kūrimo lygmenyse, ypač ruošiant miesto vystymo programas ir darbų užduotis atskirų miesto teritorijų kompleksiniam tvarkymui, ieškant racionalių sprendimų naujai struktūrai kurti ar pertvarkyti, sprendžiant viešojo ir privataus sektorių bendradarbiavimo klausimus. Sukurtas metodinis modelis yra priemoné tarpdiscipliniškumui užtikrinti. Jis leidžia nustatyti kraštovaizdžio architektūros ir urbanistikos sprendinių optimalios sąveikos gaires, numatyti socialinių funkcijų sinergiją su kuriamu kraštovaizdžiu. Tyrimui pasirinktą kriterijų sistemą dèl jos universalumo, galima taikyti įvairiuose teritoriniuose lygmenyse, nes kriteri- 
jai apima ir sisteminius, ir lokalius vertinimo aspektus. Metodiniu modeliu diegiami principai, skatinantys taupiai ir kūrybiškai naudoti gamtinius ir antropogeninius teritorijos išteklius, sudarantys prielaidas bendruomenei dalyvauti miesto vystymo procesuose.

\subsection{Sąveikos tyrimo metodinio modelio taikymas ivairiuose teritoriniuose lygmenyse}

Tyrimo autorès nuomone, siekiant tvaraus miesto tikslų būtina optimizuoti kraštovaizdžio architektūros ir urbanistikos sprendinių sąveiką bendruosiuose planuose, iš anksto numatant miesto vystymo uždavinius, kuriems spręsti reikès kraštovaizdžio architektūros kompetencijų, metodų ir priemonių. Vadovaujantis šiuolaikinèmis miestų planavimo sampratomis ir tendencijomis, svarbu, kad gamtinio karkaso teoriniai sprendiniai būtų integruoti ị žaliosios infrastruktūros diegimo sprendinius, kurie apima daugelị kitų urbanistinio planavimo aspektų. Europos Komisijos komunikate žalioji infrastruktūra apibrèžiama kaip strategiškai suplanuotas gamtinių ir pusiau gamtinių zonų tinklas, kuriame kiti aplinkos objektai suprojektuoti ir tvarkomi siekiant sudaryti sąlygas ịvairioms ekosistemų funkcijoms. Ji apima žaliąsias zonas (arba mèlynąsias, jei tai jūrinès ekosistemos) ir kitus fizinius sausumos (ịskaitant pakrantes) ir jūrinius objektus. Sausumos žaliosios infrastruktūros gali būti tiek kaimuose, tiek miestuose (Europos Komisija 2013). Miesto gamtinis karkasas planuotinas dviem etapais. Pirmuoju etapu turètų būti išskiriami svarbiausi gamtiniai komponentai ir želdynų sistemos elementai, kurie negali būti keičiami ir kurie lemia visus kitus miesto plano sprendinius - urbanistinę struktūrą, plètros kryptis. Tokie gamtiniai teritoriniai komponentai ir elementai išskiriami miesto bendrajame plane (ir (arba) jo prieduose). Antruoju - detaliojo planavimo - etapu planuojamos gamtinės (želdynų) teritorijos, ịeinančios ị urbanistinius kompleksus, tai miesto rajonų (kvartalų) apsauginiai ir rekreaciniai želdynai, žaliosios jungtys, priklausomieji želdynai ir želdiniai. Urbanistinejje struktūroje būtina formuoti integralų miesto želdynų tinklą, susiejantị gyvenamąsias ir miesto gyventojų veiklos (urbanistinio karkaso) teritorijas ir gamtinio karkaso teritorijas. Labai svarbu yra išsaugoti arba sukurti urbanizuotų teritorijų apsauginių želdinių sistemas - urbanizuotų masyvų žaliąsias perskyras arba žaliąsias jungtis. Planuojant gamtinio karkaso bei žaliosios infrastruktūros ir urbanistinès aplinkos sąveiką, rekomenduotina vadovautis gamtinio karkaso prioretizavimo kriterijais, išskiriant dvi pagrindines metodines kryptis - pirmiausia nustatomas gamtinio karkaso, kaip duotybės, pagrindinis vaidmuo miestui - ivertinamas jo potencialas ir priskiriamas prioritetas, paskui sprendžiama, ar veiksmingai su juo sąveikaus planuojamos funkcinès prioritetų zonos. Jeigu planuojamoje teritorijoje nèra fiksuoto gamtinio karkaso, tada 
sprendžiama, koks būtų tinkamiausias žaliosios infrastruktūros modelis planuojamoms funkcinio prioriteto zonoms. Vadovaudamiesi tvarumo principais planuotojai miesto teritoriją turètų nagrinèti bent jau pagrindiniais - ekonominiu, ekologiniu, socialiniu, estetiniu - aspektais. Planuojamos teritorijos kokybiniais rodikliais turètų tapti socialinès infrastruktūros užtikrinimas, rekreacinès galimybès, saugumo ir bendruomeniškumo užtikrinimo prielaidos. Tenkinant šiuos kriterijus žaliujų plotų, gamtinio karkaso ir planuojamo urbanistinio konteksto sąveika tampa ypač reikšminga. Būtent kompleksinio planavimo etape turètų būti sprendžiama, kur ir kokio pobūdžio bei dydžio rekreacinè želdyno, miesto parko erdvė geriausiai tenkins gyventojų interesus. Iškilusi problema, kaip žemesnio lygmens kompleksinio planavimo ar projektavimo metu optimaliai perkelti bendrojo plano sprendinius, nepažeidžiant miesto urbanistinės ekologinès sistemos, racionaliai lokalizuoti gamtinio karkaso ir kitų žaliųjų plotų struktūras, sukurti kokybišką socialiai pagrịstą, tvarią žaliają infrastruktūrą, sudarančią gyvenimo kokybės prielaidas ir užtikrinančią rekreacijos galimybes bei ekologinio kompensavimo funkcijas, turi būti sprendžiama papildant Kompleksinio teritorijų planavimo dokumentų rengimo taisykles (2015) arba parengiant kitas metodines nuostatas. Minètos taisyklès palieka erdvès interpretacijoms ir neteikia aiškių sąsajų tarp atskirų sprendinių skyrių, t. y. nenustato sprendinių integralumo reikalavimu.

Tyrimo metu nagrinèti visuomenei pateikto svarstyti Vilniaus miesto bendrojo plano sprendiniai atskleidžia gamtinių ir urbanistinių struktūrų sąveikos problematiką (3.2 a ir b pav.).

a)

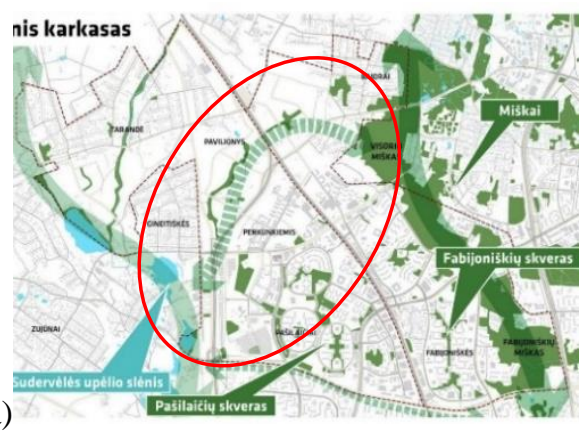

b)

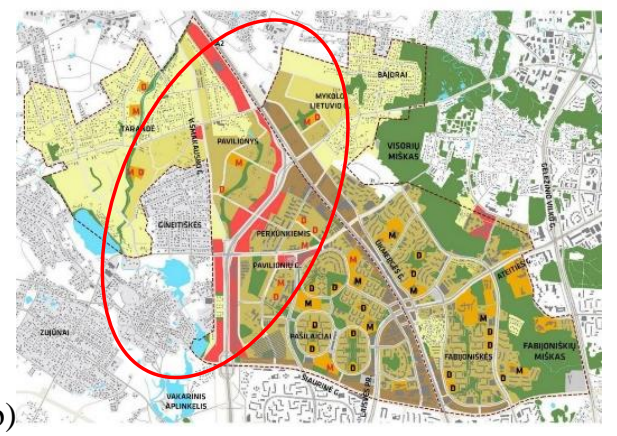

3.2 pav. Vilniaus miesto bendrojo plano sprendiniu pristatymas visuomenei. a) želdynų sistemos ir gamtinio karkaso problematika; b) pagrindinio sprendinių brèžinio ištrauka.

Šaltinis: St Vilniaus planas, 2018

Fig. 3.2. The presentation of Master plan of Vilnius city to the public.

a) The problematic of green areas and natural network; b) An extract from master plan.

Source: Vilniaus planas. 2018 
Želdynų ir gamtinio karkaso brèžinyje (3.2 a pav.) teoriškai pateikiamos pageidaujamos svarbios sisteminès žaliosios jungtys, tačiau sprendinių brěžinyje (3.2 b pav.) toje pačioje vietoje jau matome gatvę ir siūlomą intensyvų užstatymą. Akivaizdu, kad šie bendrojo plano iššūkiai turètų būti aptarti jame pačiame, numatant žaliosios jungties, gatvès ir užstatymo sinergijos principus ir priemones, sudarančias prielaidas tolesniuose etapuose imtis integralių uždavinių sprendimo. Toliau pateikiamas perẻjimo iš vieno planavimo lygmens ị kitą probleminis pavyzdys iš erdvinès gardelès principu tirtos teritorijos (3.3 a pav.). Nagrinėjama teritorija yra tankiai gyvenama, dar numatyta intensyvi jos plètra, o suplanuoti želdynai yra fragmentiški, dèl gatvių ir užstatymo pakankamai komplikuotas jų sistemos kūrimas (3.3 b ir c pav.).

a)

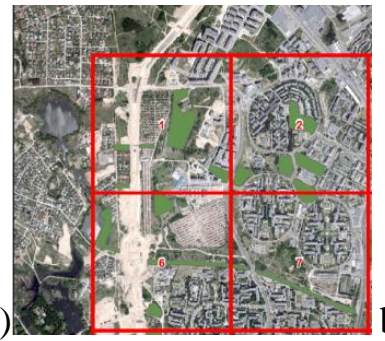

b)

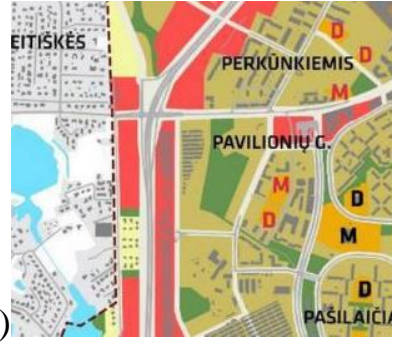

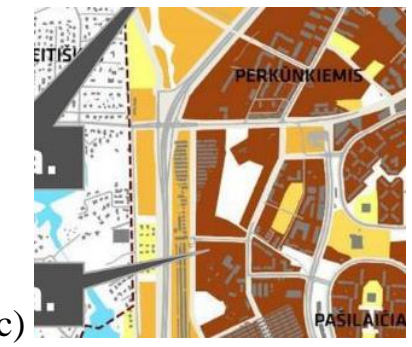

3.3 pav. Kraštovaizdžio architektūros ir urbanistikos sprendinių sąveikos problematika ir potencialas Perkūnkiemio ir Pašilaičių mikrorajone, Vilniuje. a) ištrauka iš tyrimui naudotos GIS medžiagos; b) Vilniaus miesto bendrojo plano sprendinių brěžinio ištrauka; c) Vilniaus miesto bendrojo plano ištrauka iš pristatymo visuomenei užstatymo intensyvumo brězinys. Šaltinis: St Vilniaus planas, 2018

Fig. 3.3. The problems and potential of interaction between landscape architecture and urban solutions in Perkūnkiemis and Pašilaičiai districts, Vilnius. a) an extract from the GIS material used for the study; b) an extract from Vilnius Master Plan; c) an extract from the general plan of Vilnius - the plan of the intensity of the building.

Source: Vilniaus planas, 2018

Šioje teritorijoje, siekiant aukštesnès kokybės gyvenamosios aplinkos, būtina rinktis aktyvios kraštovaizdžio architektūros ir urbanistikos sprendinių sąveikos būdus. Teritorijoje siūloma derinti mèlynosios-žaliosios infrastruktūros kraštovaizdžio tvarkymo tipą ji derinant su bendruomenès atvirų erdvių kraštovaizdžio tvarkymo tipu. Toks veikimo principas reikalauja didelès urbanistinių sprendinių koordinacijos - pirmiausia, sprendimas atviru būdu tvarkyti lietaus vandenị parką supančiame kvartale, jo kaupimo telkinius numatant parko teritorijoje. Pavyzdžiui, šiuo metu Vilniaus miesto savivaldybės užsakymu rengiami Pašilaičių parko projektiniai pasiūlymai sprendinius formuojant tik konkrečiame parko sklype, kadangi taip numatyta užduotyje, nes neturèta programos, numa- 
tančios teritorijos kraštovaizdžio tvarkymo tipą bei kraštovaizdžio architektūros ir urbanistikos sprendinių sąveikos būdus (C priedas, C2 pav.).

Prièmus sprendimą dèl mėlynosios-žaliosios infrastruktūros kūrimo, reikètų koordinuoti veiksmus su visais aplinkiniais ir toliau esančių sklypų savininkais, siūlant lietaus vandenị tvarkyti pažangiu atviru būdu, o ne nuleidžiant ị lietaus kanalizaciją. Kraštovaizdis turètų būti formuojamas tikslingai siekiant lietaus vandens atviro tvarkymo ekologiniu ir estetinių sprendinių sinergijos. Integralių estetiškai ir socialiai patrauklių sprendinių dẻka gretimų teritorijų vystytojai būtų paskatinti prisijungti prie bendros ekosistemos, kuri apimtų ir želdintus stogus. Kardinali ekologinè kraštovaizdžio tvarkymo idejja būtų puiki reklama kvartalui, kuris igautų ryškų identitetą. Atskiri bendrojo planavimo dokumentai parodė kraštovaizdžio architektūros ir urbanistinio konteksto sąveikos išraiškos galimybes ir dabar galiojančioje teisinejje teritoriju planavimo dokumentų rengimo bazejje. Kauno pavyzdys rodo, kad žaliają infrastruktūrą galima nagrinèti kaip socialinị ir ekonominį reiškinị. Šiauliu pavyzdys rodo, kad žalioji infrastruktūra galètų būti miesto vystymo ašimi. Vilniaus pavyzdys, nors ir nedrąsiai, bet jau bando sieti žaliają infrastruktūrą su inžinerine, ypač su alternatyviu lietaus vandens tvarkymu. Tačiau dar nė viename plane nèra pademonstruota ryžtingu integralių ir kompleksinių sprendinių. Šiuo atveju tiktų vienas iš naujausių visuomenès atstovų pastebejjimų apie svarstymui pateiktą Vilniaus miesto bendraji planą - advokatas Evaldas Klimas interviu „Verslo žinioms“ teigia, kad kol kas nèra aišku, koks naujojo BP vertybinis pamatas. Šia tema jis svarsto: „Gal tai paveldo apsauga ir žalias miestas? Ne, nes net suplanuotas senamiesčio skverų užstatymas. Gal tai transporto inovacijų, pavyzdžiui, elektromobilių ar judrumo skatinimas? Ne, nes nei dviračių takų, nei alternatyvaus transporto plètros galimybių nenumatyta. Priešingai - numatant urbanizaciją i pakraščius, tik toliau skatinama naudotis automobiliais“ (Zubrutè 2018).

Tyrimo rezultatai rodo, kad vertinant teritoriją visais aspektais būtina nagrinèti ne tik konkretų sklypą ar apibrezžtą teritoriją, bet ir analizuoti padètį aplinkinèse teritorijose, domèn imant ne mažesnius plotus negu nagrinèjama teritorija (3.4 a pav.). Pavyzdžiui, šiame tyrime yra pasirinkta sąlyginè $500 \times 500 \mathrm{~m}$ gardelè, todèl šios gardelès vertinimo tikslumui pasiekti, būtina nagrinèti tokio pat dydžio gardeles aplinkui - konkrečiu atveju susidaro $1500 \times 1500 \mathrm{~m}$ teritorija. Kompleksiškai ir kontekstualiai analizuojami teritorijos vertinimo rezultatų duomenys (3.4 b pav.) praplečia kraštovaizdžio architektūros ir urbanistikos sprendinių sąveikos lauką ir galimybes, teikia kontekstualią informaciją. Naujai adaptuojamas erdvinès gardelès metodas suponuoja kontekstualų požiūrị i nagrinejjimą teritoriją. Suskaidant teritoriją i apibrěžtus teritorinius vienetus išryškèja būdingi gamtinių ir urbanistinių struktūrų fizinès bei socialinès sąveikos bruožai. 


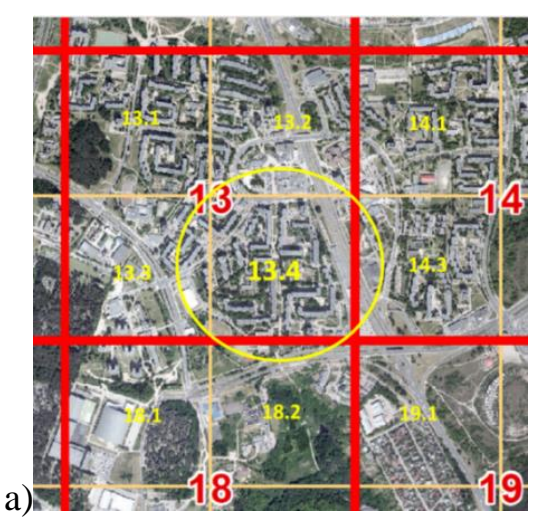

\begin{tabular}{|c|c|c|}
\hline $\begin{array}{c}\text { Ekologinis aspektas } \\
\text { VB=92 SV=0,3 } \\
\text { Socialinis aspektas } \\
\text { VB=76 } \mathrm{SV}=\mathbf{0 , 2 5} \\
\text { Estetinis aspektas } \\
\text { VB=131 } \mathrm{SV}=\mathbf{0 , 4 3}\end{array}$ & $\begin{array}{c}\text { Ekologinis aspektas } \\
\text { VB=34 SV=0,11 } \\
\text { Socialinis aspektas } \\
\text { VB }=\mathbf{7 3} \text { SV=0,24 } \\
\text { Estetinis aspektas } \\
\text { VB=79 } \text { SV=0,26 }\end{array}$ & $\begin{array}{c}\text { Ekologinis aspektas } \\
\text { VB=56 SV }=0,18 \\
\text { Socialinis aspektas } \\
\text { VB }=62 \text { SV }=0,2 \\
\text { Estetinis aspektas } \\
\text { VB=78 SV =0,26 }\end{array}$ \\
\hline $\begin{array}{c}\text { Ekologinis aspektas } \\
\text { VB=31 } \mathbf{S V = 0 , 1} \\
\text { Socialinis aspektas } \\
\text { VB=78 } \mathbf{S V = 0 , 2 6} \\
\text { Estetinis aspektas } \\
\text { VB=123 SV=0,41 }\end{array}$ & $\begin{array}{c}\text { Ekologinis aspektas } \\
\text { VB=77 SV=0,26 } \\
\text { Socialinis aspektas } \\
\text { VB }=\mathbf{7 4} \text { SV=0,24 } \\
\text { Estetinis aspektas } \\
\text { VB=76 SV=0.25 }\end{array}$ & $\begin{array}{c}\text { Ekologinis aspektas } \\
\text { VB=53 SV=0,17 } \\
\text { Socialinis aspektas } \\
\text { VB=54 SV =0,18 } \\
\text { Estetinis aspektas } \\
\text { AS }=\mathbf{7 5} \text { SV =0,25 }\end{array}$ \\
\hline $\begin{array}{c}\text { Ekologinis aspektas } \\
\text { VB=106 SV=0,35 } \\
\text { Socialinis aspektas } \\
\text { VB=125 SV=0,41 } \\
\text { Estetinis aspektas } \\
\text { VB=111 } \mathbf{S V = 0 , 3 7}\end{array}$ & $\begin{array}{c}\text { Ekologinis aspektas } \\
\text { VB=174 SV=0,58 } \\
\text { Socialinis aspektas } \\
\text { VB=111 SV=0,37 } \\
\text { Estetinis aspektas } \\
\text { VB=78 SV=0,26 }\end{array}$ & $\begin{array}{c}\text { Ekologinis aspektas } \\
\text { VB=35 SV=0,12 } \\
\text { Socialinis aspektas } \\
\text { VB=54 SV =0,18 } \\
\text { Estetinis aspektas } \\
\text { VB=75 SV =0,25 }\end{array}$ \\
\hline
\end{tabular}

3.4 pav. Teritorijos analizè: a) teritorijos analizès lauko metodinio išplètimo pavyzdys b) 13.4 gardelès ir jos gretimybių vertinimo duomenys. Šaltinis: V. Deveikienė, 2018 Fig. 3.4. The area analysis: a) the example of methodological extension of analysis field; b) The data of the cell 13.4 and the contextual cells. Source: V. Deveikienè, 2018

Vertinimas pagal parengtą kriterijų sistemą atliktas šimte gardelès $(500 \times 500 \mathrm{~m})$ metodu suskaidytų Vilniaus miesto teritorinių vienetų. Rezultatai parodè esminius sąveikos skirtumus tarp teritorijų šiaurinejje miesto dalyje, kur dominuoja laisvo planavimo užstatymo kvartalai ir pietinès dalies senamiesčio ir naujamiesčio teritorijų. Konkrečiai gardelei būdinga sąveikos specifika lyginama su gretimos gardelès ypatumais, ieškoma reikalingų ekologinių, socialinių ir estetinių sąsajų. Gardelès metodas atspindi projektavimo principą - nuo visumos prie detalès, nuo detalès prie visumos. Šis metodas skatina teritoriją nagrinèti per kraštovaizdžio prizmę, išeinant iš sklypo ribų. Gamtinių ir urbanistinių struktūrų sąveikos problematiką ir teritorijos tvarkymo sprendinius rekomenduojama sieti su gretimybėmis, išsidèsčiusiomis aplink esančiose tokio paties dydžio gardelèse. Adekvačiai plèsti analizès lauką yra naudinga dèl to, kad tiek gamtiniai, tiek socialiniai procesai neapsiriboja juridinėmis ar sąlyginèmis ribomis. Erdvinès gardelès principas leidžia sistemingai pereiti iš mažesnio teritorinio lygmens ị aukštesni ir atvirkščiai. Pavyzdžiui, nagrinejjamoje teritorijoje nèra natūralių gamtinių struktūrų (miško, vandens ar pan.), tačiau gretimoje teritorijoje (arba gardeleje) yra. Taigi, kuriant savo teritorijos ekosistemas galima (o gal ir privaloma) prisijungti prie egzistuojančių didžiujų ekosistemų. Socialine prasme taip būtų užtikrinamas teritorijos gyventojų ryšys su bendra želdynų sistema, o estetiniu požiūriu gretimų teritorijų vaizdai būtų integruoti ị kuriamą kraštovaizdị. Miesto arba dalies lygmenyje siūloma taikyti $1 \times 1 \mathrm{~km}$ gardelès dydžio tinklą, kvartalo $-500 \times 500 \mathrm{~m}$, objekto lygmenyje galètų būti taikomas $250 \times 250 \mathrm{~m}$ gardelių dydžio tinklas (C priedas C3 pav.). Vieno kvadratinio kilometro gardelès 
teritorijoje gerai matomos jungtys, gamtinio karkaso ir želdynų sistemos, taip pat probleminès pertrūkių ar fragmentacijos vietos. Tokiame lygmenyje galima pasitikrinti smulkesnių sprendinių integralumo galimybes. Kaip teigia J. Dessimini, kraštovaizdžio sistemos efektyviausios didelio masto teritorijose (Dessimini 2013). Tyrimas rodo, kad kraštovaizdžio architektūros ir urbanistikos sprendinių optimalios sąveikos uždavinius geriausia spęsti problemą nagrinėjant kvartalo lygmeniu. Todèl teritorijos analizei optimaliausiu laikytume $500 \times 500 \mathrm{~m}$ gardelès tinklą. Kontekstualiai nagrinèjant teritoriją kraštovaizdžio architektūros principai ir metodai suteikia naujų galimybių urbanistinei analizei. Taikant anamnezès principą integruojami istoriškai susiklostę kraštovaizdžio formavimo veiksniai - nuo natūralios iki sukurtos gamtos, apimant visuomenès dvasini ir simbolių lygmenį. Taikant proceso laike metodą sukuriama natūralių ir paskatintų kraštovaizdžio pokyčių dinamika. Erdvinio sekvenavimo principu yra nustatoma erdvių seka, kai viena erdvė papildo kitą, paruošia naujiems įspūdžiams kitoje erdvejje. Jungiant kraštovaizdžio architektūros ir urbanistinès analizès erdvinès kaitos principus pasiekiama gamtinių ir antropogeninių struktūrų bei procesų sinergija. Taikant kraštovaizdžio architektūrai būdingą konteksto principą kūrybiniame procese reaguojama ị aplinką - funkcijos, vaizdo ir erdvès santykiai ir jų ịvairiapusès kombinacijos bei atskiri elementai sujungiami ị bendrą kompoziciją. Konteksto principas ịpareigoja žvelgti toliau projektui arba analizei apibrežtų ribų 3.5 pav.) Paveiksle raudonai pažymètas tinklelis atitinka 13.4 gardelès ir jos aplinkos teritoriją, kurią konkrečiu atveju galime analizuoti gamtinio karkaso atžvilgiu (3.5 a pav.); miesto raidos atžvilgiu (3.5 b pav.); miesto želdynų sistemos atžvilgiu ( $3.5 \mathrm{c}$ pav.).

a)

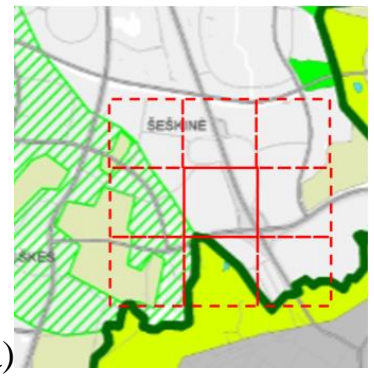

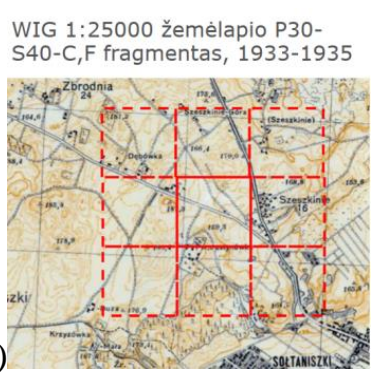

3.5 pav. Daugiasluoksnès išplèstinès analizès, taikant gardelès metodą, variantai:

a) gamtinio karkaso atžvilgiu; b) miesto raidos atžvilgiu; c) žaliosios infrastruktūros atžvilgiu. Šaltinis: V. Deveikienè, 2018

Fig. 3.5. The variants of multilayer extended analysis using the grid method: a) in relation to the natural network; b) in relation to urban evolution; c) in relation to green infrastructure. Source: V. Deveikienè, 2018 
Tokiu pat principu analizė gali būti tęsiama teritorijos kraštovaizdžio architektūros ir urbanistikos sprendinių potencialą nagrinèjant miesto morfologijos, transporto ir inžinerinès infrastuktūros, socialinių, kultūrinių, komercinių paslaugų atžvilgiu ir kitais aspektais.

Taikant erdvinès gardelès metodą teritoriją ir jos gretimybes siūloma analizuoti teritoriniais pjūviais, orientaciniu pagrindu pasirenkant pasaulio šalių kryptis. Rekomenduojama nagrinèti devynis vienetus gardelëmis suskaidytų teritorijų, kurių viduryje yra pagrindinè nagrinèjama gardelè. Glaudžiausios sąsajos yra šiaurès $(\check{S})$ - pietų $(\mathrm{P})$ ir rytu $(\mathrm{R})$ - vakaru $(\mathrm{V})$ kryptimis, nes teritorijos liečiasi ilgosiomis kraštinèmis. Realioje situacijoje ši riba gali būti visiškai formali ir sąlyginè. Vadovaujantis konteksto analizès principu, rekomenduojama teritoriją nagrinèti ir kampais susiliečiančiose gardelèse, t. y. šiaurès rytų ( $\mathrm{S} R)$ - pietvakarių (PV) ir šiaurès vakarų (ŠV) - pietryčiu (PR) kryptimis (3.6 a pav.).

Aprèpti visas kryptis yra svarbu dèl to, kad būtų užfiksuoti visi susiklostę gamtiniai ir antropogeniniai ryšiai, traukos taškai, erdvinès struktūros, tolimieji ir artimieji kraštovaizdžiai, horizonto linija, siluetas ir pan. $3.6 \mathrm{~b}$, c ir d paveiksluose pateikta 13.4 gardelès ir jos gretimybių kokybinių savybių analizès grafinè išraiška.

a)
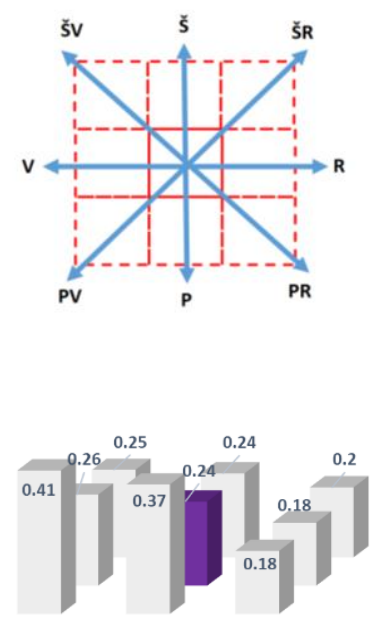

c) b)

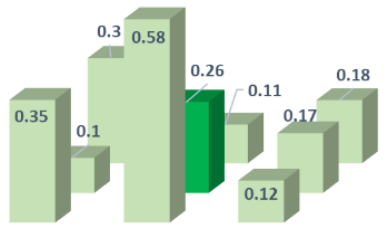

d)

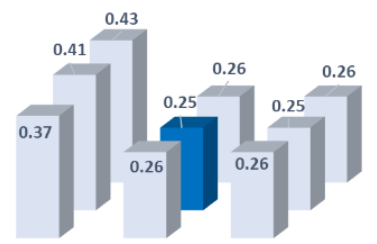

3.6 pav. Teritorijos analizès resultati: a) teritorijos išplèstinės analizès principinè schema. Gardelès (13.4) ir jos konteksto analizès grafinè išraiška: b) ekologinis aspektas;

c) socialinis aspektas; d) estetinis aspektas. Šaltinis : V. Deveikienè, 2018

Fig. 3.6. The results of territory analysis: a) the scheme of extended analysis of territory. Graphical expression of analysis of the grid 13.4. and its context : b) ecological aspect; c) social aspect; d) aesthetic aspect. Source: V. Deveikiené, 2018 
Analizuojant erdvinès gardelès metodu suskaidytą teritoriją atskleidžiami gretimybių skirtumai ir panašumai, silpnosios ir stipriosios teritorijos savybès. Teritorijos ir jos konteksto savybès interpretuojamos pasitelkiant trinarę kriterijų sistemą ir kraštovaizdžio architektūros principus. Kraštovaizdžio architektūros ir urbanistikos sprendinių sąveikos optimalumo principas teigia, kad veiksmai turi būti nukreipti ị vertybinių savybių išsaugojimą ir probleminių situacijų eliminavimą nemažinant nusistovejjusių verčiu ir orientuojantis ị aplinkos kokybinius parametrus. Nagrinėjama centrinè gardele yra atskaitos taškas ir jos kokybiniai pokyčiai yra orientuojami ị šalia esančių aukštesnès vertes turinčių gardelių savybes. Centrinès gardelès kokybinè orientacija lieka sąlyginai neutrali tų pačių ar panašių verčių teritorijų atžvilgiu, bet šios teritorijos gali būti ịdomios ieškant konkrečių verčių tendencijų ir priežastingumo. Žemesnių verčių teritorijų analizè reikalinga siekiant išvengti rizikos, kad jų prasta kokybinè būklè arba sutinkama destruktyvi sąveika gali turèti neigiamos įtakos centrinès gardelès kokybiniams procesams. (3.7 a, b, c pav.).
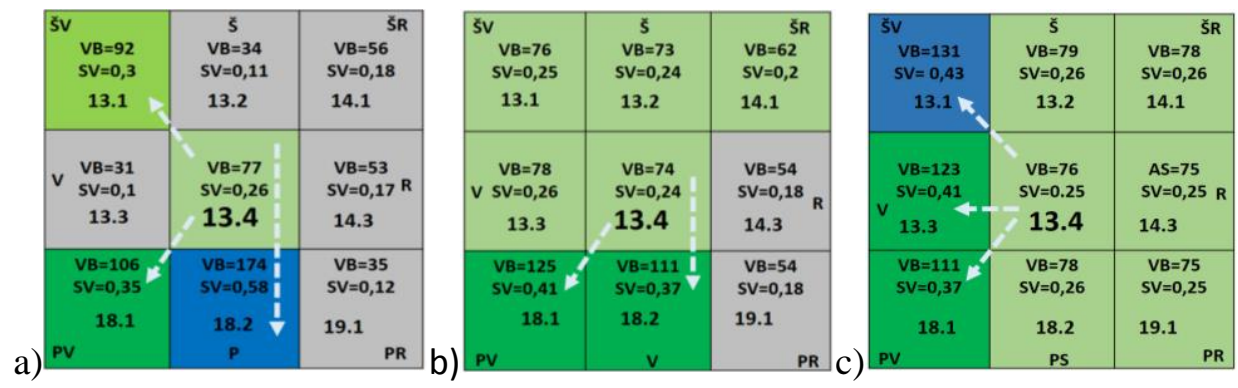

3.7 pav. Teritorijos kokybinès orientacijos schema: a) ekologinis aspektas; b) socialinis aspektas; c) estetinis aspektas. Sutrumpinimų reikšmès: VB - vertinimo balas; SV santykinis vertinimas. Šaltinis: V. Deveikienè, 2018

Fig. 3.7. The scheme of territory qualitative orientation : a) the ecological aspect; b) the social aspect; c) the aesthetic aspect. Abbreviations: VB - score; SV - relative assessment. Source: V. Deveikienè, 2018

3.5 lenteleje parodyti 13.4 gardelès kokybinès orientacijos analizès rezultatai. Jie pateikiami pasaulio šalių kryptimis. 1 - krypties pradžioje esanti gardelè, 2 - centrinè gardelè (atskaitos taškas), 3 - krypties gale esanti gardelè. Atskaitos taškas ir tokios pačios ar panašios vertès žymimos „, "; minuso ženklu žymimos mažesnès negu centrinè vertès gardelès, pliuso ženklu žymimos didesnès vertės gardelès. Du ir daugiau pliusų reiškia didesnị kokybinį skirtumą, palyginti su centrinès gardelès verte. 
3.5 lentelè. Sąveikos sprendinių 13.4 gardelejje kokybinès orientacijos metodinè analizè. Šaltinis: V. Deveikienè, 2018

Table 3.5. The methodological analysis of qualitative orientation for interaction solutions in grid 13.4. Source: V. Deveikienè, 2018

\begin{tabular}{|c|c|c|c|c|c|c|c|c|c|c|c|}
\hline \multicolumn{4}{|c|}{ Ekologinis aspektas } & \multicolumn{4}{|c|}{ Socialinis aspektas } & \multicolumn{4}{|c|}{ Estetinis aspektas } \\
\hline$\rightarrow$ & 1 & 2 & 3 & $\rightarrow$ & 1 & 2 & 3 & $\rightarrow$ & 1 & 2 & 3 \\
\hline Š-P & - & $\mathrm{O}$ & +++ & Š-P & 0 & 0 & ++ & Š-P & +++ & o & o \\
\hline V-R & - & $\mathrm{O}$ & - & V-R & $\mathrm{O}$ & $\mathrm{O}$ & - & V-R & ++ & o & o \\
\hline ŠV-PE & + & $\mathrm{O}$ & - & ŠV-PE & $\mathrm{O}$ & 0 & - & ŠV-PE & +++ & o & o \\
\hline ŠR-PV & - & $\mathrm{O}$ & ++ & ŠR-PV & $\mathrm{O}$ & $\mathrm{O}$ & ++ & ŠR-PV & o & o & ++ \\
\hline
\end{tabular}

Kaip rodo analizè, centrinès gardelès vertès tiek ekologiniu, ties socialiniu, tiek estetiniu aspektais yra labai panašios. Jos nesiekia 30 proc. maksimaliai galimos vertès, o kraštovaizdžio architektūros ir urbanistikos sprendinių sąveika balansuoja ant nuosaikios ir pasyvios sąveikos ribos. Žiūrint visais aspektais gardelèse dominuoja nuosaiki sąveikos forma, o tai reikštų kad ekologiniai klausimai sprendžiami fragmentiškai, socialiniu požiūriu trūksta bendradarbiavimo tarp atskirų dalyvių, veikiama tik tam tikrose suinteresuotose grupèse, estetinè aplinkos kokybė nukenčia dèl to, kad kraštovaizdžio architektūros sprendiniai yra epizodiški, nekuriantys visumos. Nagrinejjant ekologiniu aspektu matyti, kad šiaurès pietų kryptimi gamtinių ir urbanistinių struktūrų sąveikos laipsnis nuosekliai stiprèja, o pietinè gardèlè turi išskirtinai didelị ekologinès vertès balą. Šiuo požiūriu aktyvi sąveika reiškia, kad ekologinès vertybès yra sistemiškai saugomos. Ekologinè vertè taip pat stiprejja šiaurès rytų-pietvakarių kryptimi. Tos pačios teritorijos turi aukštesni vertinimą ir socialiniu aspektu. Estetiniu aspektu stipriausios kokybinès savybės išryškėja šiaurès vakarų pusèje, vakarų ir pietvakarių pusèje. Centrinejje (13.4) gardelèje socialiniu aspektu nustatyta pasyvi sąveikos forma - tai reiškia, kad yra mažas socialinis aktyvumas, atliekami vienpusiški neintegralūs veiksmai. Gretimose gardelèse nustatyta destruktyvi sąveikos forma ekologiniu aspektu - tai reiškia, kad šiose teritorijose yra veiksmų, ardančių ekologinị potencialą arba neleidžiančių jam susikurti. Analizès ir interpretacijos požiūriu įdomiausi ryškių verčių skirtumų priežastingumai. Daugeliu atveju verčių perkričiai sutampa su konkrečiomis teritorijų perskyromis, ypač gatvėmis. Kalbant urbanistinès aplinkos suvokimo terminais tai būtų ribos. Teritorijos savybių interpretacijos leidžia pradèti formuoti programinius uždavinius teritorijų aplinkos kokybei gerinti.

Po teritorijos vertinimo metodiniame modelyje yra rekomenduojamas prioritetų nustatymo etapas. Pageidautina, kad prioritetai būtų nustatomi ne tik centrinèje gardelëje, bet ir jos gretimybėms. Žinant gretimybių prioritetus galima optimaliau planuoti veiksmus centrinèje gardelejje, ypač tais atvejais, kai sprendiniai gali arba privalo sietis su gretimų teritorijų sprendiniais. Pavyzdyje patei- 
kiamoje 13.4 gardelëje ir jos aplinkoje esančiose atitinkamo dydžio gardelèse nustatyti kraštovaizdžio architektūros ir urbanistikos sprendinių sąveikos prioritetiniai kriterijai. Konkrečiu atveju centrinejje gardelejje pirmumo tvarka reikia spręsti ekologinio pajėgumo ir sukurtų ekosistemų klausimus. Socialiniu aspektu pirmiausia būtina spręsti saugumo ir pasiekiamumo klausimus. Estetinio aspekto prioritetu laikoma kraštovaizdžio skaitomumas ir nuoseklumas. Atsižvelgiant i tai, kad šioje teritorijoje nustatyta pasyvi sąveika socialiniu aspektu, ypatingas pirminis sąveikos stiprinimas turètų vykti prioritetiniais saugumo ir pasiekiamumo klausimais. Beveik visose gardelèse sukurtų ekosistemų prioritetas yra pirmo būtinumo uždavinys, nes pagal esamos situacijos vertinimo balus teritorijose yra labai mažai šio kriterijaus požymių. Atitinkamai svarbūs socialinio aspekto uždaviniai turi būti sprendžiami paraleliai su ekologiniais ir estetiniais klausimais. Gardelèje, kurioje buvo nustatyta aktyvi sąveika ekologiniu aspektu, pagrindinis prioritetinis uždavinys yra estetinių kriterijų kategorija - paslaptingumo didinimas. Programos kūrimo etape nustatomi kraštovaizdžio tvarkymo tipai ir (arba) rekomendacijos dèl kraštovaizdžio architektūros ir urbanistikos sprendinių bei profesinių veiksmų sąveikos optimizavimo.

Rekomendacijos teikiamos atsižvelgiant ị sąveikos esamos situacijos vertinimo rezultatus, sąveikos aktyvumo lygi ir prioritetinius kriterijus. Nustatytos kraštovaizdžio architektūros priemonès taikomos atitinkamai pagal kriterijus. Priemonių arsenalas leidžia numatyti teritorijos tvarkymo uždavinius ir išgryninti kraštovaizdžio architektūros ir urbanistikos sprendinių galimos sąveikos poreikị. Savalaikis uždavinių nustatymas yra viena iš svarbiausių sąveikos optimizavimo sąlygų ir priemonių. Kraštovaizdžio architektūros priemonès apima ekologinių, socialinių ir estetinių kriterijų grupes. Kiekvieną kriterijų grupę sudaro kriterijai, kurie buvo naudoti ir vertinant esamą situaciją, ir nustatant prioritetus, ir parenkant kraštovaizdžio tvarkymo priemones. Kriterijai atspindi sisteminius ir struktūrinius aspektus. Kiekvienam iš kriterijų atitinkamai parenkama po keturias kraštovaizdžio architektūros priemones. Kiekvienam iš kriterijų aspektui siūloma po 16 tvarkymo priemonių. Iš viso kraštovaizdžio architektūros priemonių arsenalą sudaro 48 priemonės. Metodiniame modelyje išgrynintos kraštovaizdžio architektūros priemonès yra organizacinio pobūdžio - jos nusako, kuria kryptimi rekomenduojama tvarkyti kraštovaizdi ir lemia sąveikos su urbanistikos sprendiniais galimybes. Jos taip pat parodo, kokių kompetencijų reikès igyvendinant išsikeltus uždavinius. Parinktas priemonių spektras leidžia jas lengvai derinti tarpusavyje siekiant integraliai igyvendinti ekologinius, socialinius ir estetinius uždavinius. Sprendinių integralumas yra viena iš svarbiausių sąveikos optimizavimo sąlygų. Kiekvienam iš kriterijų parenkama po vieną arba dvi priemones (atskirais atvejais gali būti ir daugiau), nes kai kurios iš jų yra pakankamai individualios, tinkančios tik konkrečiai situacijai ir nebūtinai visos taikomos vienu metu (3.6 lentelè). 
3.6 lentelè. Kraštovaizdžio architektūros priemonės uždaviniams pagal kriterijus igyvendinti. Šaltinis: V. Deveikienè, 2018

Table 3.6. The landscape architectural measures to fulfill the tasks according to the criteria. Source: V. Deveikiené, 2018

\begin{tabular}{|c|c|c|c|}
\hline \multicolumn{4}{|c|}{ Ekologiniai kriterijai } \\
\hline Natūralumas & Bioịvairovė & $\begin{array}{l}\text { Sukurtos ekosis- } \\
\text { temos }\end{array}$ & Ekologinis pajègumas \\
\hline $\begin{array}{l}\text { Apsauga ir ribo- } \\
\text { jimas }\end{array}$ & $\begin{array}{l}\text { Vietinių rūšių } \\
\text { augalų naudoji- } \\
\text { mas }\end{array}$ & $\begin{array}{l}\text { Tvari vandentvar- } \\
\text { ka, integralūs } \\
\text { sprendiniai }\end{array}$ & $\begin{array}{l}\text { Gamtinių išteklių tau- } \\
\text { pymas ir apsauga }\end{array}$ \\
\hline $\begin{array}{l}\text { Apsauga ir eks- } \\
\text { ponavimas bei } \\
\text { pritaikymas }\end{array}$ & $\begin{array}{l}\text { Savaiminių auga- } \\
\text { lų apsauga ir in- } \\
\text { tegravimas }\end{array}$ & $\begin{array}{l}\text { Apželdinti pavir- } \\
\text { šiai: žemé, stogai, } \\
\text { terasos, sienos }\end{array}$ & Vientisumas ir jungtys \\
\hline Rekultivacija & $\begin{array}{l}\text { Tikslinès simbio- } \\
\text { zès kūrimas }\end{array}$ & $\begin{array}{l}\text { Degradavusių } \\
\text { teritorijų valymas } \\
\text { ir pritaikymas }\end{array}$ & $\begin{array}{l}\text { Žaliosios infrastruktū- } \\
\text { ros sistema }\end{array}$ \\
\hline $\begin{array}{l}\text { Vandens telkinių } \\
\text { renatūralizavimas }\end{array}$ & $\begin{array}{l}\text { Priežiūros inten- } \\
\text { syvumo parinki- } \\
\text { mas }\end{array}$ & $\begin{array}{l}\text { Daržai ir akvakul- } \\
\text { tūros }\end{array}$ & $\begin{array}{l}\text { Intensyvus ir apkro- } \\
\text { voms bei taršai atspa- } \\
\text { rus apželdinimas }\end{array}$ \\
\hline \multicolumn{4}{|c|}{$\begin{array}{ll}\text { Socialiniai kriterijai } \\
\end{array}$} \\
\hline Pasiekiamumas & Itrauktis & Saugumas & Pasidalintos funkcijos \\
\hline Funkciniai ryšiai & $\begin{array}{l}\text { Erdvės įvairiems } \\
\text { žmonių porei- } \\
\text { kiams }\end{array}$ & $\begin{array}{l}\text { Apsauga nuo } \\
\text { triukšmo, karščio, } \\
\text { skersvejų ir taršos }\end{array}$ & $\begin{array}{l}\text { Inžinerinių ir krašto- } \\
\text { vaizdžio sprendinių } \\
\text { integralumas }\end{array}$ \\
\hline Vizualiniai ryšiai & Vietos identitetas & $\begin{array}{l}\text { Zonų integravimas } \\
\text { ir permatomumas }\end{array}$ & $\begin{array}{l}\text { Gretimybių funkcinè } \\
\text { ir vizualinè sinergija }\end{array}$ \\
\hline $\begin{array}{l}\text { Rekreacinių iš- } \\
\text { teklių prieina- } \\
\text { mumas }\end{array}$ & $\begin{array}{l}\text { Galimybès ben- } \\
\text { druomenės savi- } \\
\text { raiškai }\end{array}$ & $\begin{array}{l}\text { Integralūs judumo } \\
\text { sprendiniai }\end{array}$ & $\begin{array}{l}\text { Rekreacinių, komer- } \\
\text { cinių ir kitų paslaugų } \\
\text { sinergija }\end{array}$ \\
\hline $\begin{array}{l}\text { Jungčių užtikri- } \\
\text { nimas }\end{array}$ & $\begin{array}{l}\text { Orientyrai, trau- } \\
\text { kos mazgai }\end{array}$ & $\begin{array}{l}\text { Erdvių konsek- } \\
\text { vencija }\end{array}$ & Ekonominè sinergija \\
\hline \multicolumn{4}{|c|}{ Estetiniai kriterijai } \\
\hline Nuoseklumas & Skaitomumas & Sudètingumas & Paslaptingumas \\
\hline $\begin{array}{l}\text { Atvirų erdvių } \\
\text { sekos kūrimas }\end{array}$ & $\begin{array}{l}\text { Funkcinis ir este- } \\
\text { tinis susietumas }\end{array}$ & $\begin{array}{l}\text { Vaizdų kaitos } \\
\text { dinamika }\end{array}$ & $\begin{array}{l}\text { Atvirų ir uždarų erd- } \\
\text { vių kaita }\end{array}$ \\
\hline $\begin{array}{l}\text { Konteksto pa- } \\
\text { naudojimas ir } \\
\text { kūrimas }\end{array}$ & $\begin{array}{l}\text { Stiliaus vientisu- } \\
\text { mas, proporcijos }\end{array}$ & $\begin{array}{l}\text { Supančių vaizdų } \\
\text { integravimas ir } \\
\text { eksponavimas }\end{array}$ & $\begin{array}{l}\text { Daugiaplanės per- } \\
\text { spektyvos }\end{array}$ \\
\hline $\begin{array}{l}\text { Visų paviršių } \\
\text { ịveiksminimas }\end{array}$ & Kompleksiškumas & $\begin{array}{l}\text { Gamtinių ir antro- } \\
\text { pogeninių struktū- } \\
\text { rų ịvairovè }\end{array}$ & $\begin{array}{l}\text { Horizonto linijos ir } \\
\text { jos kaitos efektų sukū- } \\
\text { rimas }\end{array}$ \\
\hline $\begin{array}{l}\text { Proceso laike } \\
\text { kūrimas }\end{array}$ & $\begin{array}{l}\text { Ekologinių proce- } \\
\text { sų ir estetinio } \\
\text { poveikio sinergija }\end{array}$ & $\begin{array}{l}\text { Kontrastas tarp } \\
\text { gyvosios gamtos } \\
\text { ir statinių }\end{array}$ & $\begin{array}{l}\text { Šviesos, spalvų ir } \\
\text { formų kaita laike }\end{array}$ \\
\hline
\end{tabular}


Kraštovaizdžio architektūros priemonès atskiroms teritorijoms parenkamos dviem etapais. Pirmu etapu priemonès parenkamos pagrindinei nagrinejjamai teritorijai (gardelei) ir ją supančioms atitinkamo dydžio teritorijoms (gardelėms). Konkrečiu atveju ekologinio aspekto prioritetiniam kriterijui ,sukurtos ekosistemos" spręsti centrinèje ir beveik visose gretimose teritorijose pasiūlyta ta pati priemonè ,apželdinti paviršiai - žemè, stogai, terasos, sienos“. İgyvendinant šią priemonę sukuriamas potencialas tvariai vandentvarkai.

Atsižvelgiant ị gretimybių analizès rezultatus, nagrinejjamos teritorijos ekologinio aspekto kraštovaizdžio architektūros priemonès yra pildomos priemone „tvari vandentvarka - integralūs sprendiniai“. Ši priemonè yra labai efektyvi siekiant aktyvios kraštovaizdžio architektūros ir urbanistikos sprendinių sąveikos. Atitinkamai koreguojamas ir socialinio aspekto priemonių sąrašas - diegiant tvarios vandentvarkos integralius sprendinius prioritetinis saugumo kriterijus papildomas priemone „viešos, pusiau viešos ir privačios erdvès konsekvencija“, nes sprendžiant lietaus vandens surinkimo nuo kiekvieno pastato ir jo aplinkos klausimus būtų atitinkamai formuojamas reljefas ir laipsniškai susisiekiančios erdvės nuo pastatų iki viešosios erdvès. Estetinio aspekto kriterijaus „skaitomumas“ igyvendinimas būtų papildytas priemone ,ekologinių procesų ir estetinio poveikio sinergija“. (3.7 lentelè).

3.7 lentelè. Naujai sudarytas kraštovaizdžio architektūros priemonių sąrašas (13.4 gardelè). V. Deveikienè, 2018

Table 3.7. The newly created list of landscape architecture measures (grid 13.4).

By V. Deveikienè, 2018

\begin{tabular}{|c|l|l|}
\hline Aspektas & \multicolumn{1}{|c|}{ Prioritetai } & \multicolumn{1}{c|}{ Priemonės } \\
\hline \multirow{3}{*}{ EKOLOGINIS } & $\begin{array}{l}\text { Ekologinis } \\
\text { pajëgumas }\end{array}$ & Žaliosios infrastruktūros sistema. \\
\cline { 2 - 3 } & $\begin{array}{l}\text { Sukurtos } \\
\text { ekosistemos }\end{array}$ & $\begin{array}{l}\text { Apželdinti paviršiai - žemė, stogai, terasos, } \\
\text { sienos. } \\
\text { Tvari vandentvarka - integralūs sprendiniai. }\end{array}$ \\
\hline \multirow{3}{*}{ ESTECIALINIS } & Pasiekiamumas & Funkciniai ir vizualiniai ryšiai. \\
\cline { 2 - 3 } & Saugumas & $\begin{array}{l}\text { Integralūs judumo sprendiniai. } \\
\text { Viešos, pusiau viešos ir privačios erdvès kon- } \\
\text { sekvencija. }\end{array}$ \\
\hline & Skaitomumas & $\begin{array}{l}\text { Kompleksiškumas.Ekologinių procesų ir esteti- } \\
\text { nio poveikio sinergija. }\end{array}$ \\
\cline { 2 - 3 } & Nuoseklumas & $\begin{array}{l}\text { Visų paviršiu ìveiksminimas. } \\
\text { Atviru erdvių sekos kūrimas. }\end{array}$ \\
\hline
\end{tabular}

Nuosekliai taikant šią priemonę, ypač kvartalų kompleksinès renovacijos metu, sukuriamos palankios prielaidos tvariai vandentvarkai. Nagrinejjama teri- 
torija dèl jos suplanavimo kompozicinių ypatumų (jos viduriu praeina šiaurèspietų kryptimi suformuota jungties pobūdžio viešoji erdvė) gali būti potenciali paviršinio lietaus vandens surinkimo (sutelkimo) vieta, ji nuvedant pietų kryptimi link teritorijos su stipriu ekologiniu potencialu ir natūraliu vandens telkiniu. Bendras natūralus reljefo nuolydis yra palankus šiai idejjai igyvendinti. Taikant metodini modeli numatomi optimalūs krašovaizdžio tvarkymo tipai, kurie atspindi kraštovaizdžio architektūros ir urbanistikos sprendinių sąveikos poreikị ir pobūdị. Konkrečiu atveju galètų būti siūlomas dominuojantis kraštovaizdžio tvarkymo tipas „mèlynoji-žalioji infrastruktūra“. Pasirinkus šị tvarkymo tipą programuojama aktyvi sąveika tarp pastatų renovacijos, inžinerinių tinklų ir teritorijos tvarkymo sprendinių. Socialiniu požiūriu kuriama aktyvi sąveika tarp renovacijos proceso dalyvių - gyventojų (bendruomenių), savivaldos atstovų, renovacijos projekto vystytojų, projektuotojų. Sociokultūriniu požiūriu kuriamas kvartalo identitetas, urboekologiniu požiūriu - integrali ekosistema.

\subsection{Sąveikos optimizavimo metodinio modelio mokslinio ir praktinio pritaikymo sąlygos}

Kraštovaizdžio architektūros ir urbanistikos sprendinių sąveikos optimizavimo metodinis modelis formuoja naują požiūị ị miesto tvarkymui ir plètotei reikalingas kraštovaizdžio architektūros srities kompetencijas ir savalaikę jų sinergiją su urbanistiniais ir architektūriniais uždaviniais. Metodiniu modeliu diegiami tvaraus miesto principai, skatinantys taupiai ir kūrybiškai naudoti gamtinius ir antropogeninius teritorijos išteklius, sudarantys prielaidas bendruomenei dalyvauti miesto vystymo procesuose. Sustiprinama kraštovaizdžio architekto profesijos ir kompetencijų reikšmè miesto planavimo, urbanistinio ir architektūrinio projektavimo veiklos baruose. Metodiniame modelyje siūlomi teritorijos pažinimo, poreikių ir prioritetų suderinimo, kraštovaizdžio architektūros ir urbanistikos sprendinių sąveikos pobūdžio nustatymo ir kraštovaizdžio architektūros priemonių parinkimo etapai, kurių visuma sudarytų konkrečios vietos kraštovaizdžio tvarkymo kodą. Metodinis modelis turi kompleksinių metodų sąrangą, kuri leidžia ši modelị taikyti kaip priemonę ị miesto vystymo procesus ịtraukiant visuomenę, vietos bendruomenę, ekspertus bei kitus suinteresuotus dalyvius ir suteikia galimybę jiems dalyvauti sudarant konkrečios teritorijos ar platesnès miesto dalies kraštovaizdžio tvarkymo kodą, arba, kitaip tariant, ilgalaikę vystymo programą. (3.8 pav.). 


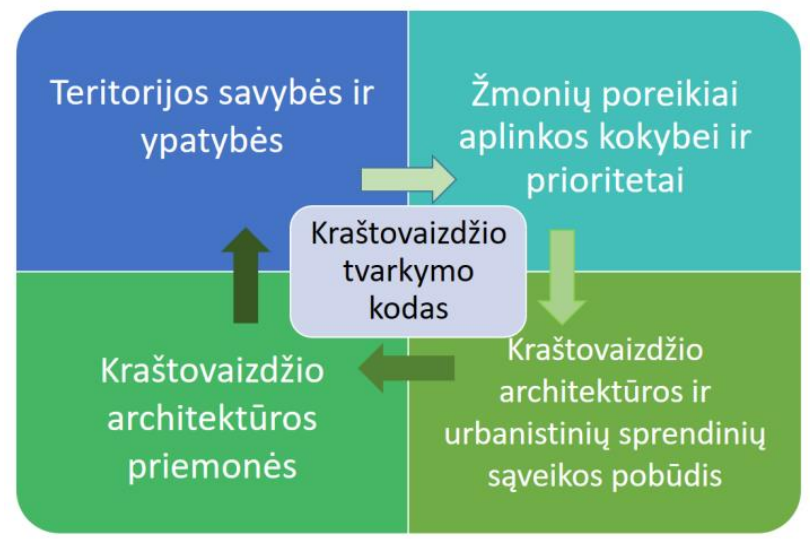

3.8 pav. Kraštovaizdžio tvarkymo kodo sudarymo schema.

Šaltinis: V. Deveikienè, 2018

Fig. 3.8. The scheme of landscape management code generation.

Source: V. Deveikienè, 2018

Tyrimo rezultatai rodo, kad gamtinès ir urbanistinès struktūros sudaro vientisą miesto audinį, o jų sąveika priklauso nuo urbanistinio proceso dalyvių - privataus asmens, visuomenès, valdžios institucijų, verslo ịmonių bei profesionalų projektuotojų - etinių nuostatų, jų savitarpio supratimo ir bendradarbiavimo. Šis metodinis modelis yra aktualus visiems miesto kūrimo proceso dalyviams ieškant racionalių sprendimų naujos urbanistinès struktūros kūrimui ar pertvarkymui, sprendžiant viešojo ir privataus sektorių bendradarbiavimo klausimus. Sukurtas kraštovaizdžio architektūros ir urbanistikos sprendinių optimizavimo metodinis modelis yra priemone tarpdiscipliniškumui užtikrinti ir yra naudingas savivaldybėms, privačioms kompanijoms ar projektuotojams, norintiems išsiaiškinti teritorijoje ir aplink ją esančiu gamtinių ir antropogeninių išteklių ypatumus ir jų kūrybinio pritaikymo galimybes. Tyrimo rezultatų taikymo prasme nauja yra tai, kad sąveikos tyrimo modelyje taikomas gardelès metodas, kurio déka nagrinejjama ne tik konkreti teritorija, bet ir medodiškai nustatytas šios teritorijos kontekstas. Gardelès metodas taip pat sudaro prielaidas, kad specifiniai teritorijos duomenys, nustatyti taikant šį naują metodinị modelị, gali būti koduojami ir integruojami ị GIS duomenų sistemą. Metodinis modelis gali būti naudojamas sudarant kodinių sąveikos tipų interaktyvų žemèlapį, nuolat pildomą ir pritaikytą vietovès aplinkos kokybei stebèti (monitoringui).

Metodologine prasme nauja yra tai, kad sukuriamas ekologinès etikos ir tvarumo principais paremtas integralus tyrimo modelis, sujungiantis metodus, igalinančius tolygiai veikiančią trinarę ekologinių, socialinių ir estetinių kriterijų sistemą. Naudojant šią kriterijų sistemą kraštovaizdžio architektūros ir urbanistikos 
sprendinių potenciali sąveika nagrinèjama lygiavertiškai visais trim minètais kriterijų aspektais. Ta pati kriterijų sistema taikoma vertinimui, prioritetų nustatymui ir tvarkymo programos kūrimui. Taikant sukurtą metodinị modelị optimalūs teritorijų tvarkymo vystymo prioritetai nustatomi vadovaujantis esamomis gamtinèmis ir antropogeninèmis ypatybėmis, o jų igyvendinimui rekomenduojami kraštovaizdžio architektūros principai, metodai ir priemonès.

Šiuolaikinio pasaulio iššūkių fone kraštovaizdžio architektūros ir urbanistikos sprendinių optimali sąveika yra sąlygojama tvaraus miesto koncepcijos, kuri pasiekiama vadovaujantis ekologine etika.Vadovaujantis ekologinès etikos vertybinèmis nuostatomis metodiniame modelyje apibrèžti tikslingumo ir optimalumo principai ir indikatoriai (3.8 lentelè).

3.8 lentelè. Kraštovaizdžio architektūros ir urbanistikos sprendinių optimalios sąveikos principai ir indikatoriai. V. Deveikiené, 2018

Table 3.8. The principles and the indicators of optimal interaction between landscape architecture and urban solutions. By V. Deveikiene, 2018

\begin{tabular}{|l|l|}
\hline \multicolumn{1}{|c|}{ Optimalios sąveikos principai } & \multicolumn{1}{|c|}{ Optimalios sąveikos indikatoriai } \\
\hline $\begin{array}{l}\text { Turimų gamtinių ir antropogeninių } \\
\text { resursų apsauga ir kūrybiškas pa- } \\
\text { naudojimas. }\end{array}$ & $\begin{array}{l}\text { Maksimaliai išsaugotos ir eksponuojamos } \\
\text { gamtinès ir kultūrinès kilmès teritorijos stip- } \\
\text { rybės. Vieningais sprendiniais ryškinamos } \\
\text { stipriosios teritorijos savybės ir šalinami trū- } \\
\text { kumai. }\end{array}$ \\
\hline $\begin{array}{l}\text { Konteksto paisymas ir kūrybiškas } \\
\text { pritaikymas. }\end{array}$ & $\begin{array}{l}\text { Metodiškai vertinamos, analizuojamos ir i̇ } \\
\text { sprendinius integruojamos gretimų teritorijų } \\
\text { stipriosios savybès. }\end{array}$ \\
\hline Socialinių paslaugų sinergija & $\begin{array}{l}\text { Veiksmais ir sprendiniais ieškoma optimalaus } \\
\text { santykio su socialine aplinka, kuriamos adek- } \\
\text { vačios viena kitą papildančios paslaugos. }\end{array}$ \\
\hline $\begin{array}{l}\text { Inžinerinių ir kraštovaizdžio archi- } \\
\text { tektūros sprendinių sinergija }\end{array}$ & $\begin{array}{l}\text { Sprendiniai vieningai generuoja gamtinius } \\
\text { (ekosisteminius) ir socialinio aktyvumo proce- } \\
\text { sus, kuriama estinè pridètinė vertè. }\end{array}$ \\
\hline $\begin{array}{l}\text { Ekologinių, socialinių ir estetinių } \\
\text { aspektų sinergija }\end{array}$ & $\begin{array}{l}\text { Lygiavertiškai sprendžiami ekologiniai, socia- } \\
\text { liniai ir estetiniai teritorijos vystymo ar tvar- } \\
\text { kymo uždaviniai, juos apjungiant vieningus } \\
\text { sprendinius. }\end{array}$ \\
\hline
\end{tabular}

Šiuo mokslo darbu sukurtas metodinis modelis iškelia bendruosius kraštovaizdžio architektūros ir urbanistikos sprendinių sąveikos principus bei optimizavimo metodines gaires ir šios sudaro placdarmą tolesniems ịvairių mokslo sričių arba tarpdisciplininiams tyrimams. Šiame darbe atliktas tyrimas atskleidè 
labai aktualius ir ateityje nagrinètinus kraštovaizdžio architektūros ir urbanistikos sprendinių sąveikos aspektus - ekologinès etikos, ekonomikos, sveikatos, teisès, visuomenès įtraukimo, tvaraus miesto ir kt. Toliau darbe trumpai aptariamos metodinio modelio taikymui svarbios ekonominès, teisinès ir tvaraus miesto planavimo sąlygos.

Kraštovaizdžio architektūros ir urbanistikos sprendinių sąveikos ekonominis aspektas yra mažai ištirtas. Jis yra labai svarbus pasirenkant sąveikos vertinimo kriterijus, siekiant racionalumo, optimalumo, naudos ir kainos protingo santykio ir pan. Tokio pobūdžio tyrimas, priklausomai nuo išsikeltų tikslų, yra daugiau ar mažiau tarpdisciplininio pobūdžio tyrimų laukas. Atsižvelgiant ị tai, kad daugelis ekonomistų ir sociologų akcentuoja gerai sutvarkytos ir prižiūrimos žaliosios erdvès vertę ir teigiamą įtaką nekilnojamiems rinkos objektams, tačiau tuo pat metu teigia, kad apleistos žaliosios teritorijos, atvirkščiai, mažina rinkos patrauklumą, darytina išvada, kad kraštovaizdžio architektūros ir urbanistikos sprendiniai turi būti ekonomiškai pagrịsti atsižvelgiant ị sprendinių sąveikos perspektyvumą, ịvertinant priežiūros kaštus. O tai jau yra susiję su racionaliais ir pamatuotais sprendimais planavimo ir projektavimo stadijose. Miesto žaliosios infrastruktūros kaina ir verte dažniausiai skaičiuojama pagal jos suprojektavimo, ịrengimo ir priežiūros kainą. Tačiau visuomenè ima suvokti ekosistemų išteklių ir jų funkcijų ekonominę naudą ir vertę. Pasaulyje ir Lietuvoje stengiamasi rasti būdų, kaip tinkamai parkų ir kitų žaliųjų erdvių sukuriamą vertę išreikšti piniginiais vienetais. Vertinant parkus, tradiciniai turto vertinimo metodai netinka, todèl mokslininkai naudojasi atskleistų preferencijų metodais (Lazdinis et al. 2011).

Daugelis gamtinių išteklių ir jų funkcijų visada buvo ir tebèra lengvai prieinami kaip viešoji gèrybė, kuriai nėra jokių rinkų ir kainų, o jų tikroji (ir ilgalaikè) vertè neįtraukta ị visuomenès ar šalies nacionalinio turto ekonominius skaičiavimus. Ekosistemų išteklių netiesioginio naudojimo ir nenaudojimo vertès bendrosios ekonominès vertès struktūroje gali būti nustatomos vartotojų pasirinkimo vertės nustatymo, kontingento vertinimo ar hedoninių kainų metodais (vertès nustatymo būdais). Hedoninių vertès nustatymo metodų ar būdų, modelių grupejje išskirtini šie vertès skaičiavimo ar pagrindimo modeliai: kelionès išlaidų, nekilnojamojo turto kainų palyginimo, gèrybès lankomumo analizès (Lazdinis et al. 2012). Hedoninio ikainojimo metodas taikomas nustatant gamtinès aplinkos paslaugų, kurios tiesiogiai daro įtaką kokio nors produkto rinkos kainai, vertei. Metodas gali būti taikomas, nustatant ekonominę naudą, susijusią su gamtinès aplinkos kokybe (oro ir vandenų tarša, triukšmas ir kt.) bei su gamtinès aplinkos malonumais (estetiniai vaizdai, rekreacinių vietovių artumas ir kt.). Hedoninio įkainojimo metodo bazinè prielaida yra ta, kad prekių rinkos kainai daro įtaką jų požymiai. Šis metodas dažniausia taikomas vertinant aplinkos naudą, kuri daro įtaką gyvenamųų namų kainai (Mizaras 2011). Miestuose 
palikti neužstatyti plotai, įskaitant žalias zonas, vandens telkinius ir miesto aikštes, suteikia gyventojams patogumų ir rekreacijos, o tai prisideda prie gyvenimo kokybès miestuose. Ekonominis miesto laisvų (neužstatytų) plotų vertinimas padeda miesto planavimui, gamtos saugojimui ir vystymui.

Hedoninio vertès nustatymo metodas plačiai taikomas JAV miesto žaliosios infrastruktūros naudai apskaičiuoti. Viena ryškesnių viešai publikuojamų metodiku prieinama interneto publikacijoje Measuring the Economic Value of a City Park system (aut. Peter Harnik ir Ben Welle, 2009, The Trust for Public Land, Chicago). Šio leidinio autoriai ịžangoje teigia, kad miesto parkų ekonominiai tyrimai yra vaikiškoje stadijoje, bet bandoma priartèti prie kai kurių esminių dalykų. Tyrimas buvo vykdomas atsižvelgiant ic septynis pagrindinius faktorius nekilnojamo turto vertę (angl. property value), turizmą (angl. tourism), tiesioginị naudojimą (angl. direct use), sveikatą (angl. health), bendruomenès sanglaudą (angl. community cohesion), švarų vandeni (angl. clean water), švarų orą (angl. clean air). Du iš faktorių teikia tiesiogines pajamas (angl. direct income) pirma, tai pakilusi nekilnojamo turto verte šalia parkų, antra - padidejęs paslaugų pardavimų kiekis dèl turistų, atvykstančių i parką. Šie faktoriai taip pat lemia gyventojų kolektyvinę gerovę (angl. collective wealth). Kiti trys faktoriai susiję su gyventojų tiesioginiu sutaupymu (angl. direct savings). Pirma dèl to, kad viešas parkas suteikia galimybes ilsètis, už kurias rinkoje yra mokami konkretūs pinigai. Antra - kad naudojantis parku yra galimybė sutaupyti išsaugant gerą sveikatą - atkrinta medicininių paslaugų mokesčiai. Pagaliau, trečias faktorius tai bendruomenès sanglauda - parkas tampa bendru kaimynijos rūpesčiu, skatina bendravimą, didina geros kaimynystès socialinį kapitalą, mažina asocialių veiksmų tikimybę, didina saugumą. Tuo pačiu mažèja išlaidos policijai, konsultacijoms, reabilitacijai, kalèjimui ir t. t. Paskutiniai du faktoriai - tai aplinkos taupymas (angl. environmental saving). Vienas iš jų - parkų sistema, joje esantys medžiai, krūmai, dirvožemis surenka didelę dali lietaus vandens ir taip sumažina lietaus vandens tvarkymo išlaidas. Ir pagaliau - švarus oras, nes medžiai ir krūmai sugeria daug oro teršalų ir gamina deguonį. Šie iš pažiūros paprasti dalykai, ịvertinti ekonominiais metodais, igauna argumento svorị, gali būti naudojami kaip svertai sprendžiant esminius miesto planavimo ar atskirų objektų projektavimo klausimus.

Lietuvos nekilnojamo turto rinkos atstovai viešuose pasisakymuose drąsiai teigia, kad žalioji infrastruktūra atlieka svarbų vaidmeni parduodant ir perkant nekilnojamaji turtą. Tačiau atkreipiamas demesys į du kriterijus - atstumą nuo miesto parko ar kitos žaliosios erdvès ir tos pačios erdvès kokybès. Nors būsto ir kito nekilnojamo turto pardavimų skelbimai paprastai akcentuoja ne tik paties pastato privalumus, bet ir aplinkos kokybę, vaizdus už lango, rekreacines galimybes, tačiau kol kas Lietuvoje nėra konkrečių, viešai pristatomų ir moksliškai pagrịstų tyrimų ir skaičiavimų, kaip suprojektuota ir ịrengta žalioji infrastruktūra 
arba, kitaip tariant, kraštovaizdžio architektūros objektai ekonomiškai sąveikauja su artimiausiais ar kontekstualiai nutolusiais, bet funkciškai reikšmingais kitais urbanistiniais objektais. Mokslinėse diskusijose dažniausiai yra cituojama užsienio patirtis.

Ekonomikos mokslininkų teiginiai teikia optimizmo turint galvoje urbanistinių kompleksų planavimo procesus, kai neužstatytos teritorijos vystytojų yra tradiciškai traktuojamos nepelningomis ir bandoma jas sumažinti iki minimumo. Neužstatytos teritorijos arba žaliụjų plotų (žaliosios infrastruktūros) vertẻs nustatymas būtų ypač reikšmingas kompleksinio detalaus planavimo metu konsoliduojant, perplanuojant ir pergrupuojant privačios nuosavybės sklypus ir dali jų priskiriant želdynų ir rekreacinei infrastruktūrai. Globalūs tarptautiniai aplinkosauginiai susitarimai, aplinkosaugos vadybos sistemų ir priemonių diegimas visose veiklos srityse, aplinkosauginis visuomenès ugdymas, kiekvieno planetos gyventojo asmeninis siekis mažinti savo ekologini pẻdsaką ir tausojančios veiklos principai gali pakreipti Žemès raidą link tvarios ekonominès, socialinès ir aplinkosauginès plètros. Tam reikalingas gerokai platesnis ekonominis gamtos išteklių, ekosistemų išteklių ir jų funkcijų vertinimas. Aplinkosauginis lavinimas turètų būti siejamas su ekonominiu prusinimu. Pasirinkus tausojančio planavimo bei tvarios plètros kelią akivaizdu, kad iškils klausimas dèl racionalaus ir pamatuoto kraštovaizdžio tvarkymo, tausojant biologinius išteklius, kuriant optimalias ị ateitị orientuotas urbanistines struktūras, tuo pačiu ir kraštovaizdžio architektūros objektus. Besaikis introdukuotų augalų naudojimas, neapgalvotas senų medžių kirtimas pakeičiant juos naujais, dirbtiniai vandens tekiniai ir reljefo formos, perteklinis miškų ar pelkių sukultūrinimas ir pan. - tai ne kas kita, kaip tam tikra ekologinio pèdsako forma, tik sukuriama plètojant ịvairaus tipo rekreacinius plotus. Tam galètų pasitarnauti ekologinio pėdsako koncepcija ir metodologija. Nors ekologinis pėdsakas yra ariamos ir agrokultūroje naudojamos žemés kiekis, kuris reikalingas vienam žmogui šeimoje arba grupei žmonių tarkim mieste, vartojantiems energiją, maistą, vandeni, gyvenantiems pastatuose ir turintiems daugybę kitokių poreikių, tačiau tikètina, kad galètų būti taikomas ir dirbtinio kraštovaizdžio poreikio ir santykio klausimas.

Kraštovaizdžio architektūros ir urbanistikos sprendinių sąveikos ekonominiu požiūriu ateities analizèms galètų būti naudinga JAV $2010 \mathrm{~m}$. išleista miesto žaliụų erdvių ekonominių tyrimų medžiaga „Atvirujų erdvių ekonominė nauda, rekreacinès paslaugos ir judrios visuomenès projektas" (angl. The Economic Benefits of Open Space, Recreation Facilities and Walkable Community Design). Atviros erdvés, kaip parkai ar rekreacinès teritorijos, gali sukurti teigiamą postūmi greta esančio nekilnojamojo turto vertei ir vesti prie proporcingai aukštesnių nekilnojamojo turto mokesčių vietos valdžiai. Ekonominis parkų ir rekreacinių teritorijų poveikis nekilnojamajam turtui priklauso nuo atstumo, atviros erdvès dydžio ir kaimynijos struktūros bruožų. Atviros erdvès ekonominès nau- 
dos dydis nekilnojamajam turtui yra aukštesnis miesto aplinkoje negu kaimiškose teritorijose. Atvira erdve, rekreacinė teritorija ir kompaktiškas planavimas municipalinei valdžiai gali duoti finansinès naudos. Lyginant su ịprastiniu planavimu, kompaktiška, pėstiesiems pritaikyta plètra gali suteikti ekonominès naudos nekilnojamojo turto vystytojams, dèl didesnių būsto kainų, atsižvelgiant ị prekès patrauklumą ir greitą pardavimą arba nuomą.

Šiuo metu Lietuvoje miesto ir gamtinès aplinkos strateginị santykị ir projektinius sprendinius reglamentuoja LR teritorijų planavimo įstatymas (2013), LR saugomų teritorijų ịstatymas (2001), LR želdynų ịstatymas (2007). Miesto ir gamtos santykiams sureguliuoti juridinị ir metodini pagrindą suteikia gamtinio karkaso, kaip ekologiškai optimizuotos gamtinès aplinkos struktūrinio modelio, ir LR želdynų ịstatymo bei jo gyvendinamujų teisès aktų nuostatos. Teisinès sąlygos Lietuvoje teritorijų planavimo, urbanistikos ir kraštovaizdžio architektūros srityse dar nèra išbaigtos. Išgyvenamas kaitos ir neapibrèžtumo laikotarpis, kai teisinis reguliavimas šiose srityse keičiamas ir nuolat papildomas. Nèra Urbanistikos, Kraštovaizdžio formavimo ar Kraštovaizdžio architektūros ịstatymų. 2017 m. priimtame Lietuvos Respublikos architektūros ịstatyme nesprendžiama daugelis aktualių problemų, tarp jų ir tarpdalykinio bendradarbiavimo, urbanistinio ir kraštovaizdžio architektūros projektavimo klausimų.

Tiek kraštovaizdžio architektūros, tiek urbanistikos sprendinių vystymui, jų sujungimui miesto gyvenamosios aplinkos kokybès vardan, labai svarbus yra žemès nuosavybès, žemès konsolidavimo miestuose teisinis reguliavimas. Aktualią žemès konsolidavimo temą nagrinèjęs E. Ramanauskas (2011) pažymèjo, kad pirmieji miesto planingos plètros pabaigos požymiai pradeda ryškèti 1995 m., nuo kurių jau nebenumatoma išpirkti miesto plètrai reikalingų teritorijų. Miesto planingos plètros pabaiga galutinai ịtvirtinama 1997 m., kai išleidžiama nauja LR Piliečių nuosavybès teisių ị išlikusị nekilnojamajị turtą atkūrimo įstatymo redakcija. Pagal LR Piliečių nuosavybès teisių i išlikusị nekilnojamaji turtą atkūimo ịstatymą, žemè prie esamų išlikusių pastatų grąžinama anksčiau miestų plètrai rezervuotose teritorijose. Vadovaujantis šio įstatymo nuostatomis, žemès reforma pradedama vykdyti „nepaisant parengtų teritorijų planavimo dokumentų“. Dėl to daugelis parengtų bendrujų planavimo dokumentų miestams ar jų dalims tampa neigyvendinami. Nuo 2002 m., pagal šio ịstatymo naują redakciją, žemé grąžinama nepriklausomai nuo to, ar buvę privatūs pastatai išlikę. Šia nuostata žemè grąžinama ar ,atkeliama“" visose neužimtose miestų teritorijose, neịvertinant net bendruosiuose planuose numatyto teritoriju rezervavimo socialinei, inžinerinei, rekreacinei infrastruktūrai, želdynams. Remiantis paskutinio laikotarpio suformuluotais tarptautiniais darniojo vystymo nuostatais viena svarbiausių jo igyvendinimo priemonių yra urbanistinis valdymas, jo stiprinimas. Šios priemonès sudarytų palankias sąlygas formuoti priimtiniausią erdvinès struktūros kompoziciją - leistų realizuoti kraštovaiz- 
džio harmoningumą užtikrinančius sprendinius ir taip pat sudarytų visas galimybes demokratiniam asmens ir visuomenès dalyvavimui kuriant kraštovaizdị (Ramanauskas 2011).

Vienas kertinių kraštovaizdžio srities teisès aktų yra Europos kraštovaizdžio konvencija, kuri buvo priimta $2000 \mathrm{~m}$. spalio $20 \mathrm{~d}$. Florencijoje (Italija), o Lietuvoje ratifikuota $2002 \mathrm{~m}$. Preambulèje taip pat pabréžiama, kad kraštovaizdis vaidina svarbų visuomenei rūpimą vaidmenị kultūros, ekologijos, aplinkos bei socialinejje srityse ir yra ekonominei veiklai palankus išteklius, kurio apsauga, tvarkymas ir planavimas gali padèti kurti darbo vietas. Konvencijoje teigiama, kad kraštovaizdis padeda formuoti vietos kultūrą ir yra viena iš pagrindinių Europos gamtos ir kultūros paveldo sudedamujų dalių, prisidedančių prie žmonių gerovès ir ịtvirtinančių Europos savastị ir kad jis yra svarbi gyvenimo kokybès dalis žmonėms visur: miesto ir kaimo vietovėse. Konvencijoje pabréžiama, kad kraštovaizdžio ịvairovès išsaugojimui didelę reikšmę turi kraštovaizdžio apsaugos, naudojimo, tvarkymo, planavimo nuostatų integravimas ị aplinkos apsaugos, teritorijų planavimo, žemès ūkio, socialinę ir kitas politikos sritis, galinčias daryti tiesiogini ar netiesioginị poveikị kraštovaizdžiui, nes tai leidžia užtikrinti, kad kraštovaizdžio klausimai nebūtų priskiriami siaurai viešojo administravimo sričiai, būtų labiau atsižvelgiama ị kraštovaizdžio tikslus priimant ịvairius sprendimus kituose sektoriuose (Europos... 2000). Lietuvos kraštovaizdžio politikoje pripažịstama, kad nacionalinės teisinès sistemos stiprinimas kraštovaizdžio apsaugos, naudojimo, tvarkymo, planavimo srityje - neatsiejama nacionalinès kraštovaizdžio politikos ir Europos kraštovaizdžio konvencijos igyvendinimo dalis. Tačiau šių dokumentų nuostatos neperkeltos i nacionalinius ịstatymus, todèl sudètinga užtikrinti kryptingą nacionalinès kraštovaizdžio politikos formavimą ir jos nuostatų integravimą ị kitus sektorius.

Lietuvos miestų planavimo ir teritorijų tvarkymo normos, teisès aktai, siejantys urbanistinius ir kraštovaizdžio architektūros, želdynų ir želdinių tvarkybos sprendinius, turètų būti integralūs ir nuoseklūs, diegiantys tvariosios aplinkos, žaliosios infrastruktūros idèjas ir principus.

\subsection{Trečiojo skyriaus išvados}

1. Kraštovaizdžio architektūra kaip ir urbanistika (miesto erdvinis planavimas ir projektavimas) yra išskirtinès disciplinos, kurių sprendiniai ir tyrimo metodai gali būti konceptualizuojami socialinių, technologinių, ekologinių, estetinių kriterijų aspektu. Šių disciplinų sprendiniais sukuriamas procesas laike ir erdvejje, kuriame svarbus lieka kontekstas, istorinè vietos informacija (anamnezè), tvariojo miesto doktrina. Disciplinų kriterijų bendrumas yra puikus pagrindas 
atsirasti kraštovaizdžio gamtinių ir urbanistinių struktūrų sąveikai, taip pat kraštovaizdžio architektūros ir urbanistikos sprendinių sąveikai.

2. Pasitelkiant trinarę teritorijos vertinimo sistemą nustatytos vietovei būdingos vertybinès ir probleminès savybès - stipriosios ir silpnosios esamos būklès charakteristikos. Taikant keturis pagrindinius kraštovaizdžio architektūros principus kuriamas naujas požiūris ị miesto tvarkymo ir plètotès prioritetus. Gamtinès ir urbanistinès struktūros nuosekliai jungiamos ị sistemas, generuojančias sinerginius procesus, ịtraukiant visus sąveikos proceso dalyvius. Naujos ekosistemos integruojamos ị esamą ekologinę sistemą, išsaugomi pagrindiniai ryšiai ir stiprinamas teritorijos ekologinis pajëgumas. Tos pačios ekosistemos tarnauja ir socialiniams žmonių poreikiams - užtikrinamas žaliụjų erdvių pasiekiamumas ir saugumas, sukuriamos erdvès visuomenès saviraiškai. Nuosekli erdvių kompozicija ir konteksto integravimas kuria darnos pojūti ir stiprina teritorijos skaitomumą ir suvokimą, stiprina vietos identitetą.

3. Atsižvelgiant ị tirtų teritorijų erdvinès raiškos pokyčių laiko tèkmèje dèsningumus, išskirtos keturios kraštovaizdžio architektūros ir urbanistikos sprendinių sąveikos aktyvumo grupès. Nustatyti aktyvumo rodikliai leidžia apibendrinti teritorijos būklę sąveikos aktyvumo požiūriu ir pagal poreiki planuoti tolimesnius veiksmus taikant kraštovaizdžio architektūros principus ir priemones. Sukuriamas naujas urbanistinès aplinkos vertinimo ir miesto plètros procesų valdymo metodinis ịrankis.

4. Naujai sukurtas metodinis modelis apima tris pagrindinius teritorijos analizès etapus - vertinimą, prioritetų nustatymą ir tvarkymo programos sukūrimą. Tyrimui pasirinktą kriterijų sistemą dèl jos universalumo galima taikyti ịvairiuose teritoriniuose lygmenyse, nes kriterijai apima ir sisteminius, ir lokalius vertinimo aspektus. Kriterijų sistema yra įvairiapusiška, aprèpia svarbiausius gyvenimo aplinkos kokybės aspektus ir žmogiškuosius poreikius. Todèl ta pati kriterijų sistema tinkama naudoti tiek vertinant esamos situacijos ypatumus, tiek nustatant prioritetinius kriterijus aplinkos kokybei gerinti. Kriterijų prioritetai išsigryninami taikant daugiakriterinès analizès metodą ir palyginami su teritorijos esamos būklès vertinimo rezultatais. Vertinimo metu nustatytų verčių ir prioritetų adekvatumas arba prieštaravimai charakterizuoja tiriamos teritorijos specifiką.

5. Erdvinès gardelès metodas suponuoja kontekstualų požiūrị i nagrinèjimą teritoriją. Suskaidant teritoriją $\mathfrak{i}$ apibrèžtus teritorinius vienetus išryškėja būdingi gamtinių ir urbanistinių struktūrų fizinès bei socialinès sąveikos bruožai. Konkrečiai gardelei būdinga sąveikos specifika lyginama su gretimos gardelès ypatumais, ieškoma reikalingų ekologinių, socialinių ir estetinių sąsajų. Gardelès metodas atspindi projektavimo principą - nuo visumos prie detalès, nuo detalès prie visumos. Šis metodas skatina teritoriją nagrinèti per kraštovaizdžio prizmę, išeinant iš sklypo ribų. Gamtinių ir urbanistinių struktūrų sąveikos problematiką ir teritorijos tvarkymo sprendinius rekomenduojama sieti su gretimybèmis, išsi- 
dėsčiusiomis aplink esančiose tokio paties dydžio gardelèse. Erdvinès gardelès principas leidžia sistemingai pereiti iš mažesnio teritorinio lygmens $\mathfrak{i}$ aukštesnị ir atvirkščiai.

6. Sukurtas kraštovaizdžio architektūros ir urbanistikos sprendinių optimizavimo metodinis modelis yra priemonè teritorijų planavimo ir vystymo tarpdiscipliniškumui užtikrinti ir yra naudingas savivaldybėms, privačioms kompanijoms ar projektuotojams, norintiems išsiaiškinti teritorijoje ir aplink ją esančių gamtinių ir antropogeninių išteklių ypatumus ir jų kūrybinio pritaikymo galimybes. Metodiniame modelyje siūlomi teritorijos pažinimo, poreikių ir prioritetų suderinimo, kraštovaizdžio architektūros ir urbanistikos sprendinių sąveikos pobūdžio nustatymo ir kraštovaizdžio architektūros priemonių parinkimo etapai, kurių visuma sudarytų konkrečios vietos kraštovaizdžio tvarkymo kodą. Metodinis modelis pasižymi kompleksinių metodų sąranga, kuri leidžia šị modelị naudoti kaip priemonę i miesto vystymo procesus ịtraukiant visuomenę, vietos bendruomenę, ekspertus bei kitus suinteresuotus dalyvius ir suteikia galimybę jiems dalyvauti sudarant konkrečios teritorijos ar platesnès mieto dalies kraštovaizdžio tvarkymo kodą, arba, kitaip tariant, ilgalaikę vystymo programą.

7. Nustatytos kraštovaizdžio architektūros ir urbanistikos sprendinių sąveikos optimizavimo metodinio modelio mokslinio ir praktinio taikymo sąlygos ekonominès, teisinès, tvaraus miesto doktrinos igyvendinimo - sudaro prielaidas praktiškai taikyti ši modeli ir ji tobulinti, adaptuoti pagal teritoriju planavimo dokumento lygmeni (projekto mastą) ir socialini užsakymą. Praktiškai modelio segmentai ir sistema buvo išbandyti ir taikyti Vilniaus miesto plètros departamente priimant sprendimus dèl derinamų projektų, taip pat diskutuojant su Vilniaus miesto visuomene dèl atskirųjų želdynų projektų, vykdant ekspertinę veiklą Lietuvos kraštovaizdžio architektų sajungoje (LKAS). 


\section{Bendrosios išvados}

1. Kraštovaizdžio architektūros sampratos raida ir profesijos kompetencijų aprašas leidžia įžvelgti jos svarbą urbanistiniuose procesuose ir patvirtina hipotezę, kad kraštovaizdžio architektūra yra neatskiriama tvaraus miesto vystymo ir urbanistinio projektavimo proceso dalis, o jai priskiriamų uždavinių pobūdis ir apimtys priklauso nuo tvarkomos teritorijos planavimo ir projektavimo lygmens, prioritetų ir programos. Kraštovaizdžio architektūros tyrimų kompleksiškumas ir integralumas yra būtina tvarių sprendinių sąlyga ir prielaida. Praktiškai bet kuri planuojama ar projektuojama teritorija, kuriai pradedami taikyti kraštovaizdžio architektūros principai, metodai ir priemonès, tampa kraštovaizdžio architektūros objektu.

2. Tyrimas atskleidè, kad visuose analizuotuose bendruosiuose planuose yra suformuoti uždaviniai susijusiję su kraštovaizdžio architektūros profesine veikla ir kompetencijomis, tačiau neužsimenama apie galimybę ar poreikị taikyti kraštovaizdžio architektūros principus ir priemones konkretiems uždaviniams spręsti. Siekiant tvaraus miesto tikslų, yra prasminga bendrojo plano rengimo stadijoje numatyti, kuriems miesto vystymo uždaviniams spręsti reikès kraštovaizdžio architektūros srities profesinių kompetencijų, metodų ir priemonių. Bendrujų planų tyrimas išryškino kraštovaizdžio architektūros ir urbanistikos sprendinių sąveikos kriterijus miesto lygmenyje - teritorijų ekologinio pajègumo, žaliųjų erdvių vientisumo, sistemiškumo kriterijus, socialiniu aspektu - pa- 
siekiamumo, integracijos, funkcijų sinergijos, estetiniu aspektu - esminių miesto vertybių apsaugą, metodinius estetinių poreikių kodavimus.

3. Ekspertai pripažino kraštovaizdžio architektūros svarbą ịvairiuose miesto kūrimo lygmenyse. Tai rodo, kad kraštovaizdžio architektūros priemonès galètų būtų aktyviau taikomos gamtinių ir antropogeninių miesto struktūros elementų sąveikos optimizavimo procese. Bendri apklausos rezultatai patvirtino prielaidą, kad kraštovaizdžio architektūros ir urbanistikos sprendinių sąveika turètų būti nagrinejjama tvarumo paradigmos požiūriu, derinant tarpusavyje ekologinius, socialinius ir estetinius prioritetus ir kriterijus.

4. Visi miesto vystymo procesai vyksta kraštovaizdžio kontekste. Gamtinès ir urbanistinès struktūros sudaro vientisą miesto audinį, o jų sąveika priklauso nuo urbanistinio proceso dalyvių - privataus asmens, visuomenės, valdžios institucijų, verslo įmonių bei profesionalų projektuotojų etinių nuostatų, jų savitarpio supratimo ir bendradarbiavimo. Šiuolaikinio pasaulio iššūkių fone gamtinių ir urbanistinių struktūrų optimali sąveika yra sąlygojama tvaraus miesto koncepcijos, kuri pasiekiama vadovaujantis ekologine etika. Vadovaujantis tvarumo paradigma, ekologine etika ir optimalumo logika, sukurta trinare vertinimo kriterijų sistema, susidedanti iš ekologinių, socialinių ir estetinių kriterijų grupių. Šios kriterijų sistemos pagalba atsakoma ị klausimus, kokius resursus turime ir kaip juos naudosime; kokius poreikius geriausiai tenkina turimi resursai ir kokiu paslaugų dar trūksta; ką gali pasiūlyti kraštovaizdžio architektūros principai ir priemonès įsisavinant ir tvarkant teritoriją. Erdvinès gardelès metodas suponuoja kontekstualų požiūrị ị nagrinèjimą teritoriją.

5. Taikant kraštovaizdžio architektūros principus gamtinès ir urbanistinès struktūros nuosekliai jungiamos ị sistemas, kintančias ir besivystančias laiko bėgyje. Esamos ir naujos ekosistemos integruojamos ị urbanistinị kraštovaizdị, kur jos tarnauja ir socialiniams žmonių poreikiams - užtikrinamas žaliujų erdvių pasiekiamumas ir saugumas, sukuriamos erdvès visuomenès saviraiškai. Ekologiniams ir funkciniams sprendiniams suteikiama estetinès išraiška, kuriamas darnos pojūtis, stiprinamas vietos identitetas.

Šiame darbe atliktas tyrimas atskleidè aktualius ir ateityje nagrinètinus kraštovaizdžio architektūros ir urbanistikos sprendinių sąveikos aspektus - ekologinès etikos, ekonomikos, fizinès ir dvasinè sveikatos, teisès, visuomenès įtraukimo, tvaraus miesto ir kt. Šis modelis iškelia bendruosius kraštovaizdžio architektūros ir urbanistikos sprendinių sąveikos principus bei optimizavimo metodines gaires ir sudaro prielaidas tolesniems įvairių mokslo sričių arba tarpdisciplininiams moksliniams tyrimams. 


\section{Literatūra ir šaltiniai}

A Letter Relating to Professional Practice from F. L. Olmsted, Sr., to Charles Eliot. July 1921. Landscape Architecture, p. 189.

Abaut-de Chastene, C. 2011. Contribution pour la caractérisation d'un " paysage urbain durable » dans les opérations d'aménagement Paris. Mokslų daktaro disertacija.

Alexander, C. 1977. Pattern Language: Towns, Buidings, Construction. New York: Oxford University Press.

Alistratovaitè-Kurtinaitienè, I.; Dijokienè D. 2013, Klaipèdos centrinès dalies morfostruktūros kaitos galimybès, Acta Academiae Artium Vilnensis / 71.

Allain, R. 2004. Morphologie urbain. Géographie, aménagement et architecture de la ville. Edition Armand Colin, Paris.

Anagnostopoulos, G. L., Dorn. H., Downing M. F., Rodel, H. 2000. IFLA past, present, future.

Bakšienè, D. 2015. Architektūros kokybès kriterijų teisinis reguliavimas: poreikis ir galimybès. Architektūros kokybès kriterijai. Mokslo straipsnių rinkinys, VGTU leidykla Technika, Vilnius.

Balsevičienè, B., Šinkariova, L., Gražulevičienè, R., Andrušaityte, S., Uždanavičiute, I., Dedelé, A., Nieuwenhuijsen, M. J. 2014. Impact of Residential Greenness on Preschool Children's Emotional and Behavioral Problems. International Journal of Envi- 
ronmental Research and Public Health, 11, 6757-6770; doi: 10.3390/ijerph110706757. ISSN 1660-4601 www.mdpi.com/journal/ijerph

Bardauskienė D., Burinskienė M. 2013. Lietuvos 2007-2011 m. Urbanistinių forumų veiklos apžvalga. VI Lietuvos urbanistinis forumas Šiuolaikiški miestai ir miesteliai: situacija, vystymosi tendencijos. Vilnius: Technika, p. 54.

Bardauskienė D., Pakalnis M. 2013. Žalioji ir rudoji urbanistika, priešprieša ar sąlytis, konformistiniai sprendimai urbanistikoje. VI Lietuvos urbanistinis forumas Šiuolaikiški miestai ir miesteliai: situacija, vystymosi tendencijos. Vilnius: Technika, p. 8.

Bardauskienè, D. 2010. Urbanizacijos sociokultūriniai aspektai kraštovaizdžio formavime. Kraštovaizdžio architektūra - patirtis, tendencijos, perspektyvos: Kraštovaizdžio architektūros forumo’2010 mokslo darbai., Vilnius: LKAS, p. 45-51.

Barghjelveh, S, Sayad, N. 2011. Using the Component Model of Sustainable Landscape for the Quality Assessment of Urban Natural Public Spaces: A Case Study from Tehran's River-valleys. International Journal Of Architecture and Urban Development, vol. 1, No.2, p. 5-24.

Batista, D., Matos, R.S. 2013. Ecology and ethics: landscape architecture and Sustainability, Scientific Conference.

Batty, M.; Longley, P. 1994. Fractal Cities: A Geometry of Form and Function. Academic Press. 394 p.

Bchir Jaber, N. 2013. Le paysage urbain, généalogie et pratiques actuelles. Mokslų daktaro disertacija.

Beyer K.M.M., Kaltenbach, A., Szabo,A., Bogar, S., Nieto, F.J., Malecki, K.M. 2014. Exposure to Neighborhood Green Space and Mental Health: Evidence from the Survey of the Health of Wisconsin. Int. J. Environ. Res. Public Health, 11, 3453-3472; doi:10.3390/ijerph110303453.

Berleant, A. 2010. Sensibility and sense: the Aesthetic transformation of the Human World. Exeter: Imprint Academic.

Berleant, A. 2016. Some questions for ecological aesthetics. Environmental Philosophy, p. 123-135.

Biržų miesto bendrasis planas. 2014. UAB „Urbanistika“.

Biržų miesto viešujų erdvių vystymo kūrybinès dirbtuvės „Biržų viešųų erdvių vizija“. 2015. Biržų rajono savivaldybė [interaktyvus], [žiūrèta 2016-02-26]. Prieiga per internetą: https://www.birzai.lt/index.php?1045004570

Brink, A., Bruns, D. 2012, Strategies for Enhancing Landscape Architecture Research, Landscape Research.

Brink, A.; Bruns, D.; Tobi, H.; Bell, S. 2017. Research in Landscape Architecture: Methods and Methodology. London: Routledge. 
Brundtland, G. H. 1987. Report of the World Commission on Environment and Development: our common future [interaktyvus] http://www.un-documents.net/our-commonfuture.pdf

Bučas, J. 2001. Kraštotvarkos pagrindai. Kaunas:Technologija. (Vadovėlis aukštųjų mokyklų studentams)

Bučys, J. 2013. Miesto lokaliu centru funkcinès ir kompozicinès struktūru squeika. Daktaro disertacija (03H). VGTU leidyklos TECHNIKA 2157-M mokslo literatūros knyga

Budriūnas R., Ėringis, K. 2000. Kraštovaizdžio estetinio rekreacinio vertinimo metodika. Vilnius: Botanikos instituto leidykla, 38 p.

Cobb, J. B. 2007. Sustainability: Economic, Ecology and Justice. Eugene, Oregon:Wipf and Stock Publishers.

Corner, J. 2006. Terra fluxus, The Landscape Urbanism Reader.

Corner, J. 2010. Landscape urbanism in the field. Topos 71, Landscape urbanism. Munich: Topos, p. 26.

Čereškevičius S. 2013. Besitraukiančių miestų fenomenas: erdvinès struktūros pokyčiai, revitalizacijos principai ir vystymo galimybès. VI Lietuvos urbanistinis forumas Šiuolaikiški miestai ir miesteliai: situacija, vystymosi tendencijos. Vilnius: Technika, p. 27-29.

Čiegis, R., Gavenauskas, A. 2005. Darnaus vystymosi valdymas: etiniai aspektai. Prieiga per internetą: http://etalpykla.lituanistikadb.lt/fedora/objects/LT-LDB

Daniel, T.C. 2001. Whither scenic beauty? Visual landscape quality assessment in the 21st century. Landscape and Urban Planning 54, p. 267-281.

Daniulaitis, G. 1999. Miesto gamtinio karkaso planavimo problemos, Urbanistika ir architektūra 23(4), p. 167-175.

Daniulaitis, G.; Dimindavičiūtė, D. 1999. Miesto žaliụu jungčių planavimo problemos, Urbanistika ir architektūra 23(4), p. 176-187.

Daujotaitè, I. 2006. Vilniaus gamtinè morfostruktūra - miesto urbanistinè savastis. Vilniaus miesto savitumai. Acta Academiae Artium Vilnensis, t. 40. Vilnius, p. 41-47.

Daujotaitè, I., Laukaitytė-Malžinskienè, G. I. 2006. Trakų rajono savivaldybės bendrojo plano gamtinės aplinkos, kraštovaizdžio, turizmo ir rekreacijos dalys. Esamos būklès vertinimas, koncepcija, sprendiniai. Mašinraštis, Vilnius

Daunora, Z. J., Kirvaitiene, S., Vyšniūnas, A. 2004. Vilniaus miesto vizualinio identiteto apsauga ir plètros principai.Vilnius: Technika, p. 151

Davis, B., Oles, Th. 2014. From Architecture to Landscape, Places Journal, Priega per internetą: [žiūrèta $2016 \quad 02$ 26] https://placesjournal.org/article/from-architecture-tolandscape/?gclid=COLu_77q09ICFUhnGQodhuwDIQ\#0 
Desai, A. R., Bhaghat, S. S. 2017. Analysis of Suitable Locations of Urban Green Space based on AHP for Surat city. Journals of Recent Activities in Infrastructure Science. Volume 2, Issue 2.

Deveikis, S., Deveikienė, V. 2009. Urbanistinė ekspansija ir miesto želdynai. Subalansuotos plètros idèjų raiška architektūroje ir teritoriju planavime: moksliniu straipsniu rinkinys. Kaunas: Technologija, p. 118-134.

Deveikis, S. 2013. Ekosistemų išteklių ir funkcijų ekonominio vertinimo aspektai. Turto vertinimo teorijos ir praktikos apybraižos. Prieiga per internetą: http://www.ltva.lt/wpcontent/uploads/2014/04/turto_vert_teorija_praktika2013.pdf. [žiūrèta 201606 26]

Disponzio, J. 2014. Landscape architecture. a brief account of origins, Studies in the History of Gardens \& Designed Landscapes, 34:3, p. 192-200, DOI:

10.1080/14601176.2014.893796. Prieiga per internetą: http://dx.doi.org/10.1080/14601176.2014.893796 [žiūrèta 201703 28]

Donadieu, P. 2012. Sciences du paysage. Entre théories et pratiques. Edition: Lavoisier, ISBN : 978-2-7430-1405-6

Dringelis, L. 1997. Miestų želdynų formavimas ir gamtinis karkasas, Urbanistika ir architektūra, 2(24), p. 25-31

Dūdėnas, J. 2015. Esminių architektūros kokybès kriterijų sąrašo struktūra. Metodologiniai aspektai. Architektūros kokybès kriterijai. Mokslo straipsnių rinkinys, VGTU leidykla Technika, Vilnius.

Ellin, N. 2006. Integral urbanism. NewYork-London: Routledge, 162 p.

Environmental Law Institute. Glossary of Terms for Brownfields. Prieiga per internetą: http://www.brownfieldscenter.org/big/glossary.shtml.

Ėringis, K., Pakalnis, R. 2005. Kraštovaizdžio politikos ištakos. Vilnius: Botanikos instituto leidykla, $192 \mathrm{p}$.

Etteger, R., Thompson, I. H., Vicenzotti, V. 2016. Aesthetic creation theory and landscape architecture. Journal of Landscape Architecture, 11:1, p. 80-91, DOI: 10.1080/18626033.2016.1144688

Europos komisija. 2010. Žalioji infrastruktūra. Informacinis biuletenis. Briuselis.

Europos komisija. 2013. Žalioji infrastruktūra. Europos gamtinio kapitalo puoselëjimas. Komisijos komunikatas Europos parlamentui, tarybai, Europos ekonomikos ir socialinių reikalų komitetui ir regionų komitetui. COM(2013) 249 final. Briuselis.

Europos kraštovaizdžio konvencija, 2002. Vilnius: Aplinkos ministerija.

Europos urbanistikos chartija, 1998. (versta iš La charte urbaine europeenne. Strasbourg, Council of Europe, Publishing and Documentation Service, 1993) Vilnius.

Franz, G., Heyde M., Bülthoff, H. H. 2003. Predicting experiential qualities of architecture by its spatial properties. 
Frey, H. 1999. Designing the City. Towards a more sustainable urban form. London: Spon Press.

Galinienè, B., Deveikis, S. 2011. Istoriniai parkai kaip ekonominis išteklius ir investicijų objektas. Edouardo Andre šiaurès parku kelias. Konferencijos mokslo darbai. Vilnius, p. 70-79.

Gamtinio karkaso nuostatai, 2007. 2014. Patvirtinta LR aplinkos ministro 2007 m. vasario 14 d. įsakymu Nr. D1-96; aktuali redakcija su 2014-01-07 įsakymo Nr. D1-22 pakeitimais.

Jellicoe, G., Jellicoe, S. 1975, 1995. The Landscape of Man. Shaping the Environment from Prehistory to the Present Day. T ISBN 9780500278192, Thames\&Hudson Ltd, London, 1995.

Girardet, H. 1999. Creating Sustainable Cities. Totnes: Green Books, p. 17-32.

Gražulevičienė, R., Venclovienė, J., Kubilius, R. Grižas, V., Dedelè, A., Gražulevičius, T., Čeponienė, I., Tamulevičiūtè-Prascienė, E., Nieuwenhuijsen, M. J., Jones, M., Gidlow, Ch. 2015. The Effect of Park and Urban Environments on Coronary Artery Disease Patients: A Randomized Trial. Hindawi Publishing Corporation BioMed Research International. Volume 2015, Article ID 403012, 9 p.

Gražulevičiūtė-Vileniškè, I., Ražauskaitè, A., Ažukaitè, L., Bartininkaitè, V., Kulbokaitė, L., Kameneckas, J. 2011. Darnaus vystymosi principais paremtas kraštovaizdžių formavimas urbanizuotose teritorijose. Miestu želdynu formavimas 2011 1(8), p. 52-65

Gražulevičiūtė-Vileniškè, I. 2010. Želdyno įtaka socialinei miesto centro aplinkai. Taikos sodų Šefilde atvejis. Miestų želdynu formavimas, 1(7), Klaipèda, p. 73-79.

Gražulevičiūtė-Vileniškè, I. 2014. Sociologiniai urbanizuotos aplinkos tyrimai: patirtys ir kryptys. Tiltai, t. 68, nr. 3, Klaipeda: KU leidykla, p. 35-52. Prieiga internete: http://journals.ku.lt/index.php/tiltai/article/view/857

Gražulevičiūtė-Vileniškè, I. 2016. Gamta mieste: tyrimų problematika, Miestų želdynu formavimas, Vol. 1, No. 13 p. 99-111

Gražulevičiūtè-Vileniškè, I., Matijošaitienè, I. 2012. The Effects of Historical Shifts on Trakų Vokè Manor Ensemble. Miestų želdynu formavimas 2012 1(9), p. 16-24

Gražulevičiutė-Vileniškè, I., Narvydas, A. 2012. Environmental Ethics and Sustainability in Housing Design. Environmental Research, Engineering and Management, No. 4(62), P. 68-80 ISSN 2029-2139

Gražulevičiūtė-Vileniškè, I., Urbonas, V. 2013. Miestų centrų regeneracijos tendencijos: miesto sodo koncepcijos persvarstymas. Miestų želdynu formavimas, 1(10), Klaipėda, p. $80-94$.

Grecevičius P., Genys J., Pridotkienė L., Marčius R., Dubra V., Urbonienė R., Olšauskas A. M., Dučinskienè E., Abromas J. 2013. Kraštovaizdžio architektūros tyrimai. Urbanizuoto kraštovaizdžio analizès ir vertinimo metodika. Klaipėda: KU leidykla, 100 p. 
Grecevičius, P., Abromas, J., Kalke,, D., Lepeška, E., Dubra, V., Genys, J. 2014. Klaipèdos miesto reprezentacinio miestovaizdžio karkasas. Kai kurie raidos ir formavimo aspektai. Miestu želdynu formavimas 2014 1(11), p. 83-89

Grecevičius, P., Olšauskas, A. M., Genys, J., Staševičiūte, R., Riepšas, E., Dubra, V., Kilijonienè, A. 2010. Kraštovaizdžio architektūros studijos Lietuvoje; būklè, kokybinès plètros poreikis ir galimybès. Kraštovaizdžio architektūra - patirtis, tendencijos, perspektyvos: Kraštovaizdžio architektūros forumo'2010 mokslo darbai., Vilnius: LKAS, p. 66-70.

Grunskis, T. 2013 Miesto viešujų erdvių sistemos samprata ir formavimo modeliai, Acta Academiae Artium Vilnensis / 71, Vilnius, p. 127-138.

Hong, S., Song, I., Wu, J. 2006. Fengshui theory in urban landscape planning. Urban Ecosyst. Springer Science+Business Media, LLC 2006, p. 221-237.

Howard, E. 1902 [1946]. Garden Cities of To-Morrow/selected and edited at website by John W. Reps. Source: http://www.library.cornell.edu/Reps/DOCS/howard.htm

Yu, K. 2010. Five Tradutions for Landscape Urbanism Thinking. Topos 71, Landscape urbanism. Munich: Topos, p. 59-62.

Ivanauskaite, A. 2015. Miesto urbanistinès formos samprata ir jos taikymo galimybès Lietuvoje. Mokslas - Lietuvos ateitis: K. Šešelgio skaitymai - $2015=$ Science - future of Lithuania: K. Šešelgis Readings - 2015. Vilnius : Technika, t. 7, Nr. 1 (2015), p. 46-54

Jacobs, J. 1961. The Death and life of Great American Cities. New York: Vintage Books, 1992, 458 p.

Jakaitis, J. 2013. Miesto erdvinio formavimo dalyviu diskursas šiuolaikinès demokratijos sqlygomis: monografija. Vilnius: Technika

Jakovlevas Mateckis, K. 2013. Miesto daugiaaukščių gyvenamujų namų teritorijų planavimo ir želdynų formavimo problemos aspektai. Kraštovaizdžio architektūra iššūkiai ir prioritetai: Kraštovaizdžio architektūros forumo’2013 mokslo darbai. 2-asis papildytas ir pataisytas leidimas, elektroninè versija, Vilnius: LKAS, p. 64-78.

Jakovlevas-Mateckis, K. 2008. Miesto kraštovaizdžio architektūra, 1 tomas: Miesto kraštovaizdžio architektūros raida ir teorijos pagrindai. Vilnius: Technika.

Jankauskaitė, A. Olšauskaitè Urbonienė, R., Abromas, J. 2015. Klaipėdos miesto istorinès dalies žaliujų erdvių analizè. Miestu želdynu formavimas, 1(12), p. 126-135

Jankevica, M. 2013. Evaluation of landscape ecological aesthetics of green spaces in Latvian large cities. Science: Future of Lithuania. Vol. 5, No. 3, p. 208-215.

Jankevica, M. 2102. Comparative analysis of methodologies for landscape ecological aesthetics in urban planning. Science: Future of Lithuania. Vol. 4, No. 2, p. 113-119.

Jauslin, D. 2010. Architecture with Landscape Methods. Doctoral thesis proposal and SANAA Rolex Learning Center Lausanne Sample Field Trip, Delft University of Technology. 
Jurkštas, V. 1994. Senamiesčiu regeneracija. Architektūros harmonizavimo problema. Vilnius: Technika, p. 159. ISBN 9986-05-139-8.

Juškevičius, P. 2005. Gyvenimo kokybė ir darnioji plètra urbanistikoje. Urbanistika ir architektūra / Town planning and Architecture, 34(4), p. 174-181.

Juškevičius, P., Burinskienè, M., Paliulis, G. M., Gaučè, K. 2013. Urbanistika: procesai, problemos, planavimas, plètra. Vilnius: Technika, p. 311-372

Kalenda, Č. 2005. Ekologinè etika: kilmè, principai, taikymas. Problemos, No. 68, ISSN 1392-1126, p. 135-147.

Kalkè, D. 2014. Kraštovaizdžio estetinio potencialo tyrimų Lietuvoje apžvalga. Mokslas - Lietuvos ateitis: K. Šě́elgio skaitymai - 2014 = Science - future of Lithuania: K. Šě̌elgis Readings - 2014. Vilnius : Technika, t. 6, Nr. 3, p. 273-281

Kalkè, D. 2015. Kraštovaizdžio estetinis potencialas: teisinė politika. Mokslas - Lietuvos ateitis: K. Šěselgio skaitymai - 2015 = Science - future of Lithuania: K. Šě́elgis Readings - 2015. Vilnius : Technika, t. 7, Nr. 1, p. 1-5.

Kamičaitytè-Virbašienè J., Godienè, G., Samuchovienè, O., Kavaliūnas, G., Radvilavičius, R. 2015. Vizualinès taršos gamtiniams kraštovaizdžio kompleksams ir objektams nustatymo metodika. Parengė UAB „Infraplanas“. Prieiga per internetą [žiūrèta 2015-05-23]:

http://www.am.lt/VI/files/File/krastovaizdis/Vizualines\%20tarsos\%20nustatymo\%20met odika.pdf

Kamičaitytė-Virbašienė J., Zaleckis K. 2014. Kauno miesto želdynų sistema: taikytini teoriniai modeliai, potencialas ir jo didinimo galimybès. Miestu želdynu formavimas. Mokslo darbai, 1 (11). Klaipèda, p. 108-118.

Kamičaitytė-Virbašienè, J., Vitkuvienė, J. 2015. Rekonstruotos Marijampolès miesto centro viešosios erdvès darnaus vystymosi dimensijų kontekste. Miestu želdynu formavimas, 1(12), p. 151-167

Kaplan, R., Kaplan, S., Brown, T. 1989. Environmental preference: A comparison of four domains of predictors. Environment and Behavior, Vol. 21 No. 5, p. 509-530.

Kauno miesto savivaldybès teritorijos bendrasis planas, 2013. Rengèjai: SI „Kauno planas“; UAB „Lyderio grupé“; UAB „Urbanistika“.

Kavaliauskas, P. 2013. Kraštotvarka ir profesinis egocentrizmas. Kraštovaizdžio architektūra - iššūkiai ir prioritetai: Kraštovaizdžio architektūros forumo'2013 mokslo darbai. Vilnius: LKAS, p. 9-20.

Kavaliauskas, P. 1974. Kraštovaizdžio rekreacinio bonitavimo sistemų metodinė apžvalga. Lietuvos TSR architektūros klausimai, t. IV, p. 73-87.

Kavaliauskas, P. 2011. Kraštovaizdžio samprata ir planavimas: mokomoji knyga. Vilnius: VU leidykla 
Kavaliauskas, P., Grigužauskaitė, S. 2014, Geosocialinių struktūrų sampratos metodologija, Geografija. T. 50. Nr. 2, p. 63-75, Vilnius, Lietuvos mokslų akademija,

Klaipèdos miesto bendrojo plano keitimas. Esama būklè, 2016. Rengejjai: UAB „Urbanistika“; UAB ,Sweco“.

Kompleksinio teritoriju planavimo dokumentu rengimo taisyklès. 2014. Patvirtinta LR aplinkos ministro $2014 \mathrm{~m}$. sausio $2 \mathrm{~d}$. įsakymu Nr. D1-8.

Kraštovaizdžio ir biologinès ịvairovès išsaugojimo 2013- $2020 \mathrm{~m}$. veiksmu planas, 2015. Lietuvos Respublikos aplinkos ministro 2015-01-09 įsakymas Nr. D1-12. Prieiga internete: https://www.e-tar.lt/portal/lt/legalAct

Kroll, L. 2012. Tout est paysage. Editeur : Sens \& Tonka; Édition : édition revue et augmentée. ISBN-10: 2845342055, ISBN-13: 978-2845342057

Landry, Ch. 2005. The Creative City. London: Earthscan, 55 p.

Lazdinis I., Rudzkienė V., Azbainis V. 2012. Saugomu ekosistemų vertinimas socialiniuekologiniu aspektu. Monografija.Vilnius, MRU leidykla.

Le Corbusier. 1935. Oeuvre complète. 1929-1934. Zurich: H. Girsberger.

Leclerc, B. 2001. Forestier et le service des Promenades. Les parcs et jardins dans L'urbanisme parisiren. XIX-XX siecles. Editeur : Action Artistique Ville Paris. 293 pages. 2001. ISBN-10: 291324632X

Leger-Smith, F.A. 2014. Evolution des pratiques des paysagistes face aux enjeux écologiques de la conception urbaine. Sous le label de L’Université Nantes Angers le Mans.

Leipcigo tvariujų Europos miestų chartija. Leipcigas, 2007.

Lietuvos profesiju klasifikatorius 2012. Patvirtintas Ūkio ministro $2013 \mathrm{~m}$. kovo $6 \mathrm{~d}$. isakymu Nr. 4-171 „Dėl Lietuvos profesijų klasifikatoriaus LPK 2012 patvirtinimo“. Vilnius: Ūkio ministerija, 499 p. Prieiga internete: http://www.ukmin.lt/uploads/documents/zip/LPK\%202012\%20arbo [žiūrèta 201610 10]

Lietuvos Respublikos architektūros ịstatymas, 2017.

Lietuvos Respublikos kraštovaizdžio politikos krypčiu aprašas (2004), patvirtintas Lietuvos Respublikos Vyriausybės 2004-12-01 nutarimu Nr. 1526.

Lietuvos Respublikos saugomu teritoriju istatymas, 1993. Nauja redakcija nuo 2001.

Lietuvos Respublikos statybos istatymas, 1996. Nauja redakcija nuo 2017.

Lietuvos Respublikos teritoriju planavimo įstatymas, 1998. Nauja redakcija nuo 2014.

Lietuvos Respublikos želdynu ịstatymas, 2007.

Lifang, Q., Yichuan, Z., Wei, C. 2008. Evaluation of urban river landscape design rationality based on AHP. Water Science and Engineering. Vol. 1, No. 4, ISSN 16742370 , p. $75-81$ 
Lynch, K. 1960. Image of the city. Cambridge, Masachusets, MTI Press.

Lynch, K. 1984. Good city form. Cambridge, Masachusets, MTI Press.

Mackevičiūtė, J. 2007. Ekologine etika ir išsamioji ekologija. Mokomoji knyga, Šiaulių universitetas.

Mačiulis, A. 2006, Vilniaus miesto savitumas: gamtos ir architektūros darna. Vilniaus miesto savitumai. Acta Academiae Artium Vilnensis, t. 40. Vilnius, p. 7-16.

Mahdiraji, H. A., Arzaghi, S., Stauskis, G., Zavadskas, E.K. 2018. ID A hybrid fuzzy BWM-COPRAS method for analyzing key factors of sustainable architecture. Sustainability, Vol. 10, 1626; doi:10.3390/su10051626, p. 2-26.

Marot, S. 1995. L'alternative du paysage, Le visiteur, No. 1.

Masboungi, A. 2001. Penser la ville par le paysage. Projet Urbain. Edition de la Villette.

Maslow, A. 1943. A theory of human motivation. Psychological Review, No. 50, p. 370396.

Mendel, L. C., Kirkpatrick, J. B. 1999. Assessing temporal changes in the reservation of the natural aesthetic resource using pictorial content analysis and a grid-based scoring system - the example of Tasmania, Australia. Landscape and Urban Planning, 43, p. 181-190.

Minimum requirements European landscape architectural studies to qualify for professional recognition by EFLA and ECLAS, 2011.

Mirkarimi, S.H., Arrowsmith, C. 2017, The history of the changing nature of protected area management objective. Environmental Resources Research Vol. 5, No. 1.

Mizaras S. 2011. Miškai - šalies žaliasis auksas. Kaip nustatyti verte? Prieiga per internetą: http://www.forest.lt/go.php/lit/2/3588 [žiūreta 201606 13].

Morin, E. 1980. La méthode 1. La nature de la nature, Seuil, Paris,.

Mostafavi, M., Najle, C. 2004. Landscape Urbanism: A Manual for the Machinic Landscape, AA Publications.

Mumford, L. 1938. The Culture of Cities. New York: Brace and Company.

Mumford, L. 1968. The Urban Prospect. New York: Harcourt, Brace and the World.

Nassauer J. I. 2012. Landscape as medium and method for synthesis in urban ecological design. Landscape and Urban Planning. Vol. 106, p. 221-229

New Urban Agenda. English. 2017. United Nations. ISBN: 978-92-1-132731-1

Ode, A., Tveit, M. S., Gary Fry, G. 2008. Capturing Landscape Visual Character Using Indicators: Touching Base with Landscape Aesthetic Theory. Landscape Research, 33:1, 89-117, DOI: $10.1080 / 01426390701773854$ 
Palmer, J. 2003. Research Agenda for Landscape Perception. Trends in Landscape Modelling, Proceedings at Anhalt University of Applied Sciences.

Petrušonis, V. 2010. Kultūrinio konteksto reikšmė vertinanat architektūrinị kompleksą. Urbanistika ir architektūra, 35(4), p. 252-261.

Pilkauskas, R. 2004. Kraštovaizdžio architektūra Lietuvoje, Acta Academiae Artium Vilnensis, I 33, Vilnius, p. 7-49.

Purvinas, M. 1983. Primenenye arkchitekturno-landshaftnogo analiza v protsesse proyektirovaniya [Purvinas, M. Kraštovaizdžio architektūros analizès taikymas projektavimo procese], Lietuvos TSR architektūros klausimai VIII (I).

Ramanauskas, E. 2011. Lietuvos kultūrinio kraštovaizdžio formavimo raida ir jo erdvinio optimizavimo prielaidos (1918-2008). Mokslų daktaro disertacija.

Romain, F. 2010. La construction contemporaine des paysages fluviaux urbain. Le cas de deux villes nord méditerranéennes : Perpignan et Montpelier. Mokslų daktaro disertacija.

Saaty, T.L. 2008. Decision making with the analytic hierarchy process. Int. J. Services Sciences, Vol. 1, No. 1.

Salado, A., Nilchiani, R. 2013. Using Maslow's hierarchy of needs to define elegance in system architecture, Procedia Computer Science, Vol.16, p. 927-936.

Salingaros, N. A. 2005. Principles of Urban Structure. Design/science/planning. Amsterdam, Holland: Techne Press.

Samalavičius, A. 2013. Miestas ir protas. Urbanistinès teorinès refleksijos XX a. Vakaruose. Vilnius: Technika, p. 74-80, 127-147

Samuchovienė, O., Godienė, G., Braga, A., Matijošaitienė, I. et al. 2013. Kraštovaizdžio formavimo gairès valstybiniams keliams ir geležinkeliams. Lietuvos Respublikos aplinkos ministerija. Kaunas. 133 psl. ISBN 978-9955-37-162-5

Sgard, A. 2010. Une « éthique du paysage » est-elle souhaitable http://journals.openedition.org/vertigo/9383

Soulier, H. 2006. La friche urbaine : déchet ou ressource? Mokslų daktaro disertacija.

Stamps III, A.E. 2004. Mystery, complexity, legibility and coherence: A meta-analysis, Journal of Environmental Psychology, No. 24, p. 1-16.

Staniūnas E., Stauskis G. 2011. Rekreacijos kompleksai gamtinejje aplinkoje. Vilnius: Technika, $192 \mathrm{p}$.

Staniūnas, M. 2013. Ekologijos aspekto vertinimas miestu bendruosiuose planuose. Daktaro disertacija. Vilnius: Technika, p. 25-38. Prieiga internete: http://vddb.library.lt/fedora/get/LT-eLABa-0001:E.02 2013 D_20131125_10031139419/DS.005.0.01.ETD 
Start with the park. Creating sustainable urban green spaces in areas of housing growth and renewal. 2005. Commission for Architecture \& the Built Environment.

Stauskas, V. 1966. Landšafto ịvertinimo metodika, planuojant poilsio rajonus, Lietuvos TSR architekturos klausimai III.

Stauskis G., Eckardt F. 2011. Empowering public spaces as catalysers of social interactions in urban communities. Urbanistika ir architektūra 2(35), Vilnius: Technika, p. $117-128$.

Stefulesco, C. 1993. L'urbanisme végétal. Paris Edition Institut pour le développement forestier.

Stobbelaar, D.J., Pedroli, B. 2011. Perspectives on Landscape Identity: A Conceptual Challenge. Landscape Research, Vol. 36, No. 3, p. 321-339.

Stonkuvienè, I. 2004. Asmens ir gamtos santykiai kaimo bendruomenès požiūriu. Acta Pedagogica Vilnensia, No. 12, ISSN 1392-5016, p. 183-197.

Šiaulių miesto bendrasis planas, 2008. Rengèjas: UAB „Urbanistika“.

Thompson, I. H. 2000. Aesthetic, Social and Ecological Values in Landscape Architecture: A Discourse Analysis, Ethics. Place \& Environment, , p. 269-287

Thompson, I. H. 2012. Ethics \& aesthetics of architecture \& the environment. Newcastle upon Tyne, UK

Thompson, I. H. 2012. Ten Tenets and Six Questions for Landscape Urbanism. Landscape Research, 37:1, 7-26, DOI: 10.1080/01426397.2011.632081

Tjallingii, S. 2005. Green Structure and Urban Planning, general outcomes of Cost C11. Green Structure and Urban Planning. COST action C11 final report. COST Office, p. 249-256

Toublanc, M., Bonin, S. 2012. Planifier les trames vertes dans les aires urbaines : une alliance à trouver entre paysagisme et écologie. Développement durable et territoires, Vol. 3, Nr. 2. |URL : http:// developpementdurable.revues.org/9347, DOI: 10.4000/developpementdurable.9347 (žiūrèta 2017-04-02)

Turner, T. 1996. City as Landscape. Alden Press, Oxford

Tutlytė, J.; Stauskas, V. 2001. Lietuvos kraštovaizdžio estetinis potencialas ir jo santykis su rekreaciniu interesu zonomis. Kultūriniu kraštovaizdžių apskaita ir apsauga: konferencijos pranešimu medžiaga.

Urbonaitè, I. 2013. Rekreaciniu funkciju raiška Vilniaus miesto erdvinèje struktūroje. Mokslų daktaro disertacija.

Utenos miesto bendrasis planas, 2008. Rengejjas: UAB „Urbanistika“.

Vaitkevičiūtè, V. 2007. Tarptautinių žodžių žodynas, Vilnius, leidykla „Žodynas“, p.789 
Vaitkus, G. 2006. Lietuvos CORINE žemès dangos GIS duomenu bazès taikomojo panaudojimo aplinkosaugos srityje studija.

Vanagas, J. 2006, Vilniaus miesto savitumai ir viena jo teritorinès plètros alternatyvų. Vilniaus miesto savitumai. Acta Academiae Artium Vilnensis, t. 40. Vilnius, p. 29-39.

Veinberga, M, Zigmunde, D. 2016. Aesthetics and Ecology in Planning of Urban Green Spaces of Latvia. Landscape Architecture and Art. Scientific Journal of Latvia University of Agriculture, Vol. 8, Nr. 8, p. 43-52.

Veteikis, D., Jukna, L., Jankauskaitè, M. 2015. Kraštovaizdžio struktūros pokyčiu probleminiuose arealuose vertinimas vietiniu lygmeniu. Ataskaita.

Vilniaus miesto savivaldybès teritorijos bendrojo plano sprendiniu igyvendinimo 20072014 metais stebésenos (monitoringo) ataskaita. 2015.

Vilniaus miesto Vilniaus miesto savivaldybès teritorijos bendrasis planas, 2018. Rengiamas. SI „,Vilniaus planas“.

Waldheim, Ch. 2010. On Landscape, Ecology and other Modifiers to Urbanism. Topos 71, Landscape urbanism. Munich: Topos, p. 21.

Waldheim, Ch. 2014. Introduction: landscape as architecture. Studies in the History of Gardens \& Designed Landscapes.34:3, 187-191, DOI: 10.1080/14601176.2014.893140

Vyšniūnas, A. (2013). Architektūra ir urbanistika sampratų ir žanrų pinklèse. Acta Academiae Artium Vilnensis: Terra Urbana., t. 71. Vilnius: VDA leidykla, p. 25-46.

Zagorskas, J. 2007. Miestų kompaktiškumas ir darniosios plètros modeliavimas. Daktaro disertacija Technologijos mokslai, statybos inžinerija - 02T. VGTU leidykla Technika.

Zaleckis, K., Kamičaitytė-Virbašienè, J. 2011. Urbanistinių struktūrų potencialo vertinimas: Kauno centras miesto visumos kontekste. Urbanistika ir architektūra, 4(35), p. 249-259.

Zaleskienè, E., Kamičaitytė-Virbašienè, J., Gražulevičiūtè-Vileniškè, I. 2013. Aesthetic aspects of landscapes in the rural-urban interface zones. Acta Biol. Univ. Daugavp., Vol. 13, No. 1, p. $173-188$.

Zavadskas, E.K., Simanauskas, L., Kaklauskas, A. 1998. Sprendimu paramos sistemos statyboje. Vilnius:Technika, p. 124-132

Zubrutè, L. 2018. Naujas sostinès planas: prioritetai ir grèsmès. Verslo žinios. $2018 \mathrm{~m}$. gegužès 30 d. Nr. 82 (4884).

Žalioji infrastruktūra. 2010 [interaktyvus]. Prieiga per internetą: http://ec.europa.eu/environment/pubs/pdf/factsheets/green_infra/lt.pdf 


\section{Autorès mokslinių publikacijų disertacijos tema sąrašas}

\section{Straipsniai recenzuojamuose mokslo žurnaluose}

Deveikienè, V. 2018. Methodological guidelines for optimizing the interaction between landscape architecture and urban planning. Landscape architecture and art, Vol 12, Nr 12. ISSN 2255-8632 print; ISSN 2255-8640 online, Jelgava (Latvia), p. 7-21.

Deveikienė, V. 2018. Kraštovaizdžio meno raiškos mieste svarba pagal tikslinès apklausos rezultatus, mokslo darbų žurnalas Miestu želdynu formavimas (angl. Formation of Urban Green Areas) Vol. 1(15), ISSN $1822-9778$ print; ISSN 2029-4549 online, Klaipèda, p. 8-17.

Stauskis, G., Deveikiene, V. 2016. Assessing Quality of City Development by the Acquired Criteria of Landscape Urbanism. Architecture and Urban Planning. Scientific Journal of Riga Technical University, Vol.12, ISSN 1691-4333. e-ISSN 22558764, p. 37-43.

Deveikienė, V. 2016. Kraštovaizdžio architektūros objekto ir urbanistinio konteksto sąveikos problema igyvendinant miestų bendrujų planų sprendinius $=$ The problem of the interaction between the object of landscape architecture and urban context in the implementation of city's master plan solutions. Mokslas - Lietuvos ateitis: 
K. Šěselgio skaitymai - 2016 = Science - future of Lithuania $:$ K. Šě̌elgis Readings 2016. Vol. 8, Nr.1. Vilnius: Technika. ISSN 2029-2341, p. 48-64.

Deveikienè, V. 2015. Kraštovaizdžio architektūros ir urbanistikos sąveika - ar turime bendrą tikslą? = The interaction between landscape architecture and urban development. do we have a common goal? Mokslas - Lietuvos ateitis: K. Šešelgio skaitymai- 2015 = Science - future of Lithuania: K. Šě̌elgis Readings - 2015. Vol.7, Nr.1. Vilnius: Technika. ISSN 2029-2341, p. 6-19.

\section{Straipsniai kituose recenzuojamuose leidiniuose}

Deveikienè, V. 2016. Žalioji infrastruktūra kaip tvariosios aplinkos inžinerijos ir kraštovaizdžio architektūros sąveikos rezultatas = The green infrastructure as the result of the interaction of sustainable environmental engineering and landscape architecture. 19-osios Lietuvos jaunuju mokslininku konferencijos „Mokslas - Lietuvos ateitis" temine konferencija = Proceedings of the 19th Conference for Junior Researchers „Science - Future of Lithuania. Vilnius, eISBN 978-609-457-950-9, p. 33-40.

Deveikienè, V., Stauskis, G. 2017. Kraštovaizdžio architektūros ir urbanistikos sąveikos aspektai: XX a. Pirmoji pusè. Renè Andre (1867-1942) epocha. Kraštovaizdžio architekto kūrybos laukas - nuo želdynu iki miesto planavimo: mokslo darbai. ISBN 978-609-95567-6-5 (spaudinys), ISBN 978-609-95567-5-8 (elektroninis leidinys internete), Vilnius, p. 7-14.

Deveikienė V., Deveikis, S. 2017. Le Jardin dans un milieu urbain - la ville conçue et dressée depuis la fin de XIXe siècle jusqu'à nos jours |The Garden in an Urban Setting - the City Designed and Erected since the End of 19th Century to the Nowadays (8951) // FIG Working Week 2017 Surveying the world of tomorrow from digitalisation to augmented reality, Helsinki, Finland, May 29-June 2, 2017. Proceedings. ISBN 978-87-92853-61-5, ISSN 2307-4086. Prieiga per internetą: http://www.fig.net/resources/proceedings/fig_proceedings/fig2017/papers/ts02j/TS02 J_deveikiene_deveikis_8951.pdf 


\section{Summary in English}

\section{Introduction}

\section{Formulation of the problem}

The problem of optimal interaction between landscape architecture and urban solutions is considered in the context of the synergy of the ecological, socio-economic and aesthetic needs of the city in order to reveal the role of landscape architecture in solving the problems of compatibility of these needs. The role of the landscape grows from aesthetic and representative spaces along - architectural urban landscape objects are able to perform the role of ecological "vessels" and connections. By applying the principles of landscape urbanism, it is possible to create links between dynamic environmental processes and urban forms (Corner, 2006). The problem of research of the relation between the city and nature is inseparable from the problems of landscape research in general, related to such features of today's landscapes as rapid changes and their large scale, increasing complexity of landscapes, fragmentation both in the physical, visual, and ecological sense, and also due to the intersecting and not always visible social, cultural, economic and other interests (Gražulevičiūtè-Vileniškè, 2016). However, according to James Corner (2006), the understanding remains that creating a landscape is equal to the creation of beautiful pastoral imagery that it is an antipode to the corroding modern urban environment and social life. Disputes are mostly not so much about different creative tools or ideas, but about significant degree of professional exclusion and area of influence (Corner, 2006). In Lithuania, also, the essence and significance of landscape architecture is not yet unanimously understood at theoretical level or in professional ac- 
tivities. The field of landscape architectural competences and creative activity are still treated very differently both in practice and science. The landscape architecture and urban planing specialists, often without understanding or not evaluating the importance of timely cooperation, by negating or ignoring each other. The exclusion problem begins at the level of strategy setting and urban planning and moves to the levels of block and object planning and design. In urban processes, without timely focusing on specialists with landscape architecture competences, the problems of interaction between natural and urban structures are often not addressed at all - by formal assessment of the current situation, unilateral prioritization, without utilising the possibility of rational and creative use and integration of natural and anthropogenic resources. By ignoring the principles, methods and creative tools of landscape architecture, the issues of integration of the city's natural framework and green spaces become problematic, the quality of recreation and daily environment suffers, the architectural, engineering and even social infrastructure solutions become poorer. The main question is what determines the interaction between landscape architecture and urban solutions, what is the meaning of this interaction for addressing the ecological, social and aesthetic needs of the city, and how can this interaction be optimized in solving the problems of coherence between natural and urban structures?

\section{Relevance of the thesis}

The relevance of the issue of interaction between landscape architecture and urban solutions is determined by the contemporary challenges of the city's quality of life, requiring greater synergy between natural and urban solutions. The Amsterdam Pact signed in 2016, which sets out the EU Urban Agenda, and the New Urban Agenda (2017) adopted by the UN Conference on Habitat III, promotes addressing of urban challenges through sustainability paradigm, which means that many of the future urban challenges will be directly related to conservation of natural and cultural resources, preservation and enhancement of biodiversity, alternative energy, climate change issues, sustainable water cycle assurance, public participation, environmental quality assurance, etc. In the 21 st century, the science of urbanism is looking for ways to integrate the methods and findings of the various scientific fields, focusing in particular on the landscape and its management as an alternative way and approach in addressing sustainable urban issues, taking into account the abundance and integrity of services provided by landscape. Compared to other design and planning processes, landscape methods integrate environmental processes and identify beneficial synergies (Nassauer, 2012). At the scientific level, in Lithuania, the issues of interaction of solutions between landscape architecture and urban solutions have been little studied, and no detailed methodological studies, summaries and recommendations have been provided. The work is relevant because it aims at methodological linking of scientific studies that deal with landscape and urban problems in different aspects and in different areas of science and practice. The work seeks to better utilize the potential of methods and tools of landscape architecture, developing the perspective of interdisciplinary collaboration. 


\section{The object of research}

The research focuses on the interaction between landscape architecture and urban solutions and the role of landscape architecture in urban development processes The research is limited to urban territories - the problem of rural, agricultural and completely natural territories is not addressed in this work.

\section{The aim of the thesis}

By revealing the evolution and role of landscape architecture in the city, to create a methodological model for optimizing the interaction between landscape architecture and urban solutions based on the principles of sustainable development.

\section{The tasks of the thesis}

In the order to reveal the aim of the thesis, the following tasks must be solved:

1. To analyse the peculiarities and trends of the expression of landscape architecture in urban processes from the middle of the 19th century to the present day.

2. To analyse potential manifestations of interaction between landscape architecture and urban solutions in spatial planning documents.

3. To reveal the role assigned by foreign and Lithuanian experts to the landscape architecture in the city development.

4. To prepare the research model based on sustainability principles and to investigate the selected territories of the city of Vilnius, split into identical territorial units by the grating method.

5. To discuss the application of the methodological model of optimization of interaction between landscape architecture and urban solutions at various territorial levels and the conditions of its application in science and practice.

\section{The research methodology}

Due to the multidimensional nature of the research object, the complex research methods are used in the work. The peculiarities of the concept and development of the phenomenon under investigation, and applied methods were analysed by using the methods of scientific literature, bibliographic and iconographic sources, analysis of legal acts and other documents. The potential interaction between landscape architecture and urban solutions on the teritorial planning level using the method of comparative analysis and the established criteria. In order to find out the views of experts in landscape architecture and urbanism on the peculiarities of interaction between these areas, the sociological Delphi survey method was used. On the basis of scientific literature analysis and expert survey results, a three-dimensional system of ecological, social and aesthetic criteria has been developed, based on which the evaluation of the chosen territory was carried out and management priorities were set. Statistical information and monitoring methods were used to determine ecological and social values. The method of aesthetical perception was chosen to determine the aesthetic values (Kaplan \& Kaplan, 1989; Stamps III, 2004). The Multi Criteria Decision Making (MCDM), AHP (Analytic Hierarchy Process) method is used for prioritisation of needs by criteria (Saaty 2008; Lifang, Yichuan, Wei 2008). Recommendations on the implementation of the priority criteria and targets set in the territory in the course of the research are provided through the principles of 
multilayer analysis, process, space sequencing and context, applied in landscape architecture (Marot, 1995; Jauslin, 2010). The main natural elements forming the city are the relief; water bodies and vegetation are analyzed in relation to the elements of perception of the urban structure - paths, nodes, edges, landmarks, districts, by adapting the Kevin Lynch's urban analysis method, applied increasingly often in the landscape architecture research (Lynch, 1960; Bchir Jaber, 2013).

\section{Scientific novelty of the thesis}

By the research in dissertation new scientific results are achieved:

1. The reaserch on the interaction between landscape architecture and urbanism is new thing in the scientific point of view.

2. The new is the creation of an integral research model based on ecological ethics and sustainability principles, the essence whereof consists of a threemember, coherently functioning system of ecological, social and aesthetic criteria.

3. Using this criterion system, the interaction in the defined territories is analysed equally in all three aforementioned aspects of the criteria. The same system of criteria is applied to the evaluation, prioritization and programme identification.

4. The model of the interaction research is based on the grating method methodically determins the context of territory. The grating method also creates the assumptions that the specific data of territory identified by applying this new methodological model can be encoded and integrated into the GIS data system.

\section{Practical value of the research findings}

The results of the work are relevant to all participants in the city's development process, in particular in preparing urban development strategies, programs and tasks for the integrated management of individual city territories, seeking rational solutions for the development or reorganization of a new urban structure, addressing issues of public-private sector cooperation.

The methodological model implements the principles of sustainable city, which stimulate the cost-effective and creative use of natural and anthropogenic resources of the territory, creating preconditions for community participation in urban development processes. It enhances the significance of the landscape architect's profession and competencies in urban planning, city and architectural design activities. The methodological model can be used to create an interactive map of coded interaction types that is constantly updated and adapted for the monitoring of the quality of the location surroundings.

\section{Defended statements}

1. All urban processes take place in the context of the landscape and are inevitably linked to the natural basis, and therefore the issues of city regeneration and development should be analyzed and addressed through the landscape and the links between natural and anthropogenic processes. Landscape architecture, according to its own competences, solves the issues of parents of buildings with the nature, and therefore every urban or architectural phenomenon associated 
with the natural basis or individual natural elements is a potential object of creative activity of landscape architecture.

2. The landscape architecture and urban solutions are constantly interacting. The concept of this interaction depends on the dominant paradigm of the city's development, the ethics and competences of the process participants. Today's sustainable city policy, ethics, principles and objectives presuppose criteria for optimal interaction between landscape architectures and urban development solutions, which will determine timely priorities for the protection and management of landscape, rational protection and optimum use and creative adaptation of natural and anthropogenic resources for people's needs.

3. Sustainable urbanism is not possible without landscape architecture solutions. By application of principles, methods and tools of landscape architecture, the city's ecological, aesthetic and social needs are optimally matched and solved by combining them into a unified, sustainable system that operates in time.

\section{Approval of the dissertation}

A total of six articles were published in peer-reviewed scientific journals and two in other peer-reviewed publications on the topic of the dissertation. In addition, six presentations and one poster presentation on the subject of the dissertation were presented at the scientific conferences of Lithuania and other countries.

\section{The structure of the dissertation}

The dissertation consists of the introduction, three chapters, the list of references and the list of author's publications on the topic of dissertation. Volume of the work -175 pages of text. The main part of the work contains 34 figures and 15 tables, 183 references. 10 annexes are supplied in the enclosed compact disc.

\section{Landscape architecture - complex part of the city creation process}

The work covers the modern city period - from the second half of the 19th century to the present day. The work reveals the evolution of the conception of landscape architecture, and the review of activities "advances" the usage of professional name by more than half a century, shifting it to the beginning of the 19th century. It is a new fact in the Lithuania and scientific literature, that will determine the new features of the history of landscape architecture as an academic subject. The work reveals how the profession of landscape architect was involving from urban improvement functions to solutions of urban planning issues, becoming a participant in urban design and, in many cases, the initiator of unified complex solutions. The analysis of international practice indicates that landscape architecture is an exclusive discipline that generates designer competencies that allow them to take on the tasks of rational and creative integration of natural and urban processes, both in the stages of city strategy development, and planning and design stages. It is assumed that the application of principles, methods and means of landscape architecture, urban management achieves optimal interaction of natural and city structures.

The modern urban theories and practices of some countries recognise that natural and urban structures comprise natural and urban structures form the integral fabric of the 
city, and their interaction depends on the ethical attitudes of the urban process participants - the private person, the public, authorities, business enterprises and professional designers, their mutual understanding and collaboration. In the context of the challenges of today's world, the optimal interaction of natural and urban structures is conditioned by the concept of a sustainable city, which is achieved through ecological ethics.

At the moment, society is embracing the economic benefits and value of ecosystem resources and their functions. According to the property appraisers, the list of the nearest future tasks should include the development of a methodology for determining the economic value of developed or created green areas - parks, squares. Foreign and Lithuanian medical researchers have confirmed the direct influence of parks and other green areas of the city on human physical health, the development of a child, and the spiritual condition of society. It has been found that the higher level of green spaces in neighbourhoods is associated with a significantly lower level of symptoms of depression, anxiety and stress in these territories. Recently, recreational functions of the landscape have become more and more commonplace with the content of formed or rehabilitated territories. Research analysis has shown that the field of research in landscape architecture and urbanism is significantly different in Lithuania and abroad. In foreign scientists works landscape architecture is considered as an integral part of urban research or the city is analyzed as a landscape. Similar research in Lithuania is divided between landscape research and urban research. Urban research is characterized by the fact that even in the analysis of open urban spaces, practically no mention is made of the landscape architecture phenomenon.

Since urban solutions are inevitably linked to the natural basis of the territory and the formation of the landscape, it is clear that the principles, methods and tools of landscape architecture can benefit the urban landscape analysis and solutions. The main principles of landscape architecture seek to create a process in a time, to master all surfaces, to offer activity and work methods and to concentrate the imagination. The fundamental difference between of landscape architecture approaches from traditionally applied urbanism methods is that they integrate natural, social and cultural environmental processes and identify their beneficial synergies. Each of the listed landscape architectural methods is complex by nature and involves other important analytical and research methods. In practice, any planned or designed territory, for which the principles, methods and tools of landscape architecture are applied, becomes the object of landscape architecture.

\section{Framework of research of interaction between landscape architecture and urbanism}

According to the tasks of the work three main reshearches have been developed. The process of spatial planning is the fundamental to the interaction between urban and landscape architecture and it programs the follow-up sequence and priorities. Taking into account the needs of integrated planning, it is investigated how the general planning documents of Lithuanian cities reflect the interaction of green infrastructure with other urban solutions. The research showed that all of the general plans examined had more or less measures planned and recommendations provided for further implementation of solutions for the development of green infrastructure and landscape - all the analyzed general plans contain tasks for the localization of the natural framwork, the development 
of the greenery system, and landscape formation, which are essentially related to the professional activities and competences of the landscape architecture. However, none of the general plans are discussing the possibility or need to apply the principles, methods and tools of landscape architecture to solve specific problems. The study of general plans highlighted the criteria for optimizing the interaction between landscape architecture and urban solutions at the city level - the criterion of ecological capacity of the territories, integrity of the green spaces, the systematicity criterion, from the social aspect availability, integration, function synergy, from the aesthetic aspect - the protection of essential city values, methodical codifications of aesthetic needs.

In the process of interaction between landscape architecture and urban solutions, specialists in the planning, design and management of cities play a very important role; it is important to examine their views about the role of landscape architecture in the city. All respondent groups unambiguously attribute the greenery system to the landscape architecture object, which indicates the importance of landscape architecture in various levels of city development: starting with the city planning, where the greenery system "is born" at the strategic level, followed by urban design, where the system of green areas is integrated into districts with specific urban solutions, giving it a conceptual form, setting up functional priorities, boundaries, etc. The results of the expert survey indicate that principles of territorial analysis and design such as a multilayered systemic analysis of the territory; analysis and development of natural and anthropogenic processes; establishing and developing a consecutive sequence of open spaces, are included in the field of landscape architecture. Landscape architecture principles and creative measures are recognized by all respondents as most important to these sustainable urban processes: saving and utilization of natural resources; prioritizing in the assessment of the current situation; restoration of degraded territories; sustainable water management. To a large extent, the opinions of the experts of both professions coincide, which testifies to the credibility of the statements, the general attitude to the city planning and design priorities, and prospects for further cooperation.

The analysis of the interaction between natural and urban elements of the structure has been chosen as a platform for the expression and the manifestation of interaction between landscape architecture and urban solutions. Any city or design solutions have theoretical contact with nature, and when implemented, this contact takes physical expression, the quality whereof depends on the design (theoretical) solutions. The elements of the city structure perception adapted for interoperability analysis - perhaps, nodes, edges, landmarks, districts have fully proved in the study as they well reflect the characteristic nature of the places of interaction of natural and anthropogenic structures, allow a systematic and integrated look at the urban fabric of the analyzed territory.

The research focuses on the provocative interaction developed by human actions, which determines further processes and interactions. The question of the optimality of interaction is raised and the definition of optimal interaction is formulated. There are usually three main groups of people involved in urban processes in one or another process of interaction. These are the customer (may be private or public), the creator (designer) and the public (user). Any of these three actors may be the first to "move" the process towards a new interaction. Ideally, all three groups understand and evaluate the situation, in which the new interactions occur, in a similar manner; in such case one can 
expect optimal decisions to be made. The optimal interaction is characterized by the preservation of semantics, rational use of resources and elimination of repetition of excessive functions (Fig. 2.1.).

Fig. 2.1. The diagram of interaction: a) the dependence and change of interaction optimality; b) formation of interaction optimization criteria. Source: V. Deveikiené, 2018

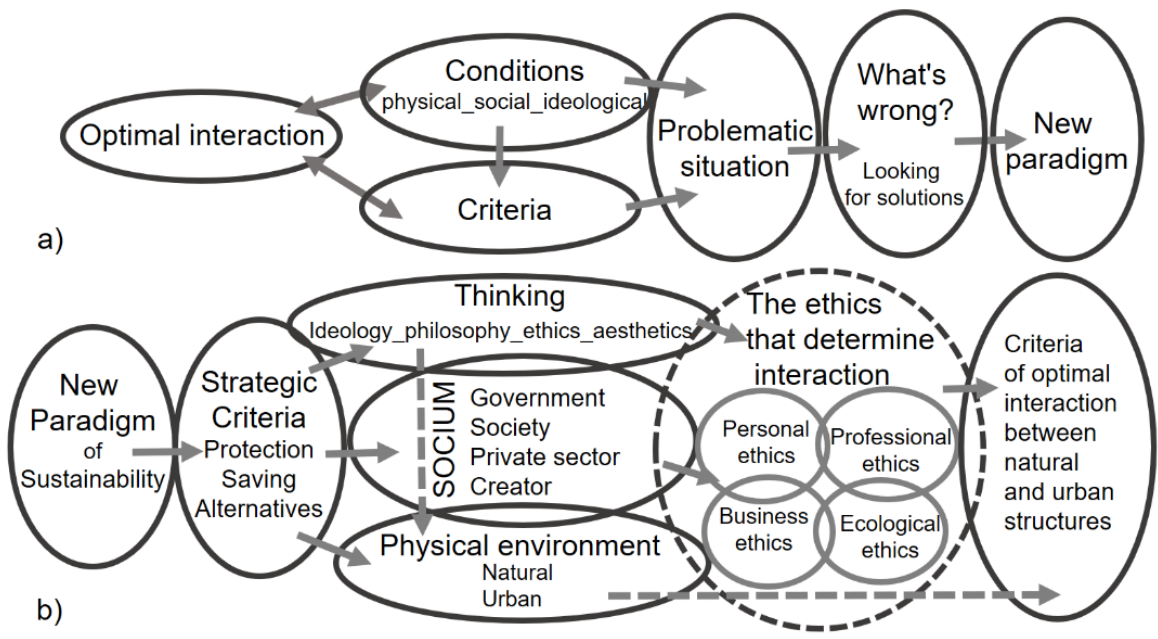

Ecological ethics becomes an integral part of modern ethics, which justifies the necessity of each of us responsible behaviour in nature and outlines the moral orientations of our behaviour in the present world (Kalenda, 1998). In traditional ethics, only an individual is considered to be the subject of morality, and in modern ethics, especially in applicable ethics, the subject is an organization, community, society, and humanity (Kalenda, 2005).

The optimal interaction of landscape architecture and urban design solutions is treated as the result of human activity in finding the best solution according to predetermined criteria. This interaction is characterized by the preservation of semantics, rational use of resources and elimination of repetition of excessive functions. Natural and urban structures form the integral fabric of the city, and their interaction depends on the ethical attitudes of the urban process participants - the private person, the public, authorities, business enterprises and professional designers, their mutual understanding and collaboration. In the context of the challenges of today's world, the optimal interaction of natural and urban structures is conditioned by the concept of a sustainable city, which is achieved through ecological ethics. The paradigm of sustainable urban development encourages the use of natural and anthropogenic resources in a cost-effective and reasonable manner, therefore, before engaging in the tasks of urban territory management, it is necessary to have a comprehensive knowledge about the properties of the territory in question and its context. The adapted Maslow pyramid of human needs and motivation (Maslow, 1943), in which, according to the scale of needs, we interpreted the landscape management levels, is used for the analysis of the landscape and living environment. In 
accordance with the sustainability paradigm, ecological ethics and logic of optimality, a three-dimensional system of landscape architecture and urban solutions and interaction, consisting of ecological, socio-functional and aesthetic criteria groups, was developed.

The three groups of criteria are drawn up in such a way that the results of the evaluation in one aspect provide information or raise the question to another aspect. The ecological group of criteria covers natural resources and their sustainable use, social criteria include the needs of people and the development of quality services, and aesthetic criteria help to decide on composite measures to create an appropriate emotional impact. The same criteria system is used for the assessment of the territory, prioritization and development of landscape management strategies and programmes. The purpose of this assessment is to highlight the features of the territory - strengths and weaknesses, so that we can make decisions about how to strengthen the weak positions without weakening the strengths. By using the spatial grating network method, the author's prepared model on the research of the interaction between landscape architecture and urban solutions was tested. For the research, the quarters located in the northern part of Vilnius, with main urban framework formed in around 1980-1990, but quite well developed at the present time, were chosen. The research focuses on the issues at the quarter level. The research analysed the interaction between the natural and urban structures of the territory, treating the latter as an important field of creative activity of the landscape architecture. In order to cover as many potential scenarios as possible in the expression of landscape architecture, we chose to explore not specific objects, but to examine the continuous problematic urban territory, covering it uniformly in a spacious grating. The research is based on the ortho-photo photo and other GIS data. The territory is uniformly covered with $1 \mathrm{sq}$. km grating, which corresponds to the division of the quarter level.

The method of this size of a standard grating is applied in European landscape monitoring systems and specialists recommend the transition to a unified landscape monitoring system in Lithuania (Veteikis et al., 2015). Relevant research in assessing the peculiarities of interactions between natural and urban structures was carried out in separate $500 \times 500$ m gratings.

The results of the research have shown the essential differences of interaction between the territories. The unequal distribution of natural recreational resources in densely populated neighbourhoods is clearly evident. The lowest interaction values were found especially in areas where transport infrastructure is dominant, in the residential or commercial building environment, lacking natural elements. The northern territory is characterized by forested inserts, which dominated in a particular grate in individual cases. The results of the research show significant differences in values between entirely adjacent territories.

Interpretation of the results of this assessment can be useful both in the phases of assessment, prioritization and design. An optimal set of priority criteria is determined by applying the multi-criteria analytical hierarchy process (AHP) method. The results are compared with the results of the expert assessment of the current state of the territory. From the point of view of the interpretation of the research results, the most interesting and relevant are the largest differences between the assessment of the current situation and the priority areas of needs, which essentially show the direction of priority activities. 


\section{Methodological model for optimizing the interaction of landscape architecture and urban solutions}

Landscape architecture is an exclusive discipline that generates designer competencies that allow them to take on the tasks of rational and creative integration of natural and urban processes, both in the stages of city strategy development, and planning and design stages. By applying methods, principles and tools of landscape architecture, the ecological, aesthetic and social needs of the city are optimally matched and solved by combining them into a unified, sustainable system that operates in time and generates permanent natural and social processes that ensure optimal interaction between landscape architecture and urban solutions and actions. According to James Corner (2006), they landscape architecture methods are important because, when being guided by them, it allows to create a process over time; these are time-continuing; staging of surfaces; operational or working methods are suggested; imaginary helps create impressive compositions using the natural and man-made resources available.

French scientist Sébastien Marot (1995) has refined four principles, or so-called methods of landscape architecture (Marot, 1995; Jauslin, 2010). By conceptualizing the results, these methods are useful in that they enable all the priority tasks to be addressed simultaneously, combining the solutions of the interaction research into one whole: anamnesis; process; spatial sequencing; context. Landscape architecture, like urbanism (city spatial planning and design), are the exceptional disciplines whose solutions and research methods can be conceptualized in terms of social, technological, ecological, aesthetic criteria. The solutions of these disciplines create a process in time and space, in which the context, historical local information (anamnesis), the doctrine of a sustainable city remain important. The commonality of the criteria of disciplines is a great basis for interaction between landscape's natural and urban structures, as well as the interaction between landscape architecture and urban solutions.

By applying the four main approaches to landscape architecture, a new approach to urban management and development priorities is developed. Natural and urban structures are consistently interconnected to systems that generate synergistic processes involving all participants in the interaction process. New ecosystems are integrated into the existing ecological system, preserving the key links and strengthening the ecological capacity of the territory. The same ecosystems serve the social needs of people - ensuring the accessibility and security of green areas, creating spaces for self-expression of the public. The coherent composition of spaces and the integration of context creates a sense of harmony and strengthens the readability and perception of the territory, and enhance the local identity. Four interactions between landscape architecture and urban solutions activation groups have been drafted. The determined activity indicators allow to generalize the status of the territory from the point of view of interaction activity and to plan further actions according to the need, i.e., to search for the most efficient and optimal ways of managing the territory, by applying the principles and tools of landscape architecture. This creates a new, sufficiently versatile urban environmental assessment tool suitable for addressing urban design, city development processes, and assessment projects at social, ecological and aesthetic aspects at various territorial levels.

In accordance with the principle of landscape architecture, to create processes in time, a diagram is presented on how the priority criteria for managing the territory de- 
termined by multi-criteria analysis evolve over time and gradually boost the values of the remaining criteria (Fig. 3.1.).

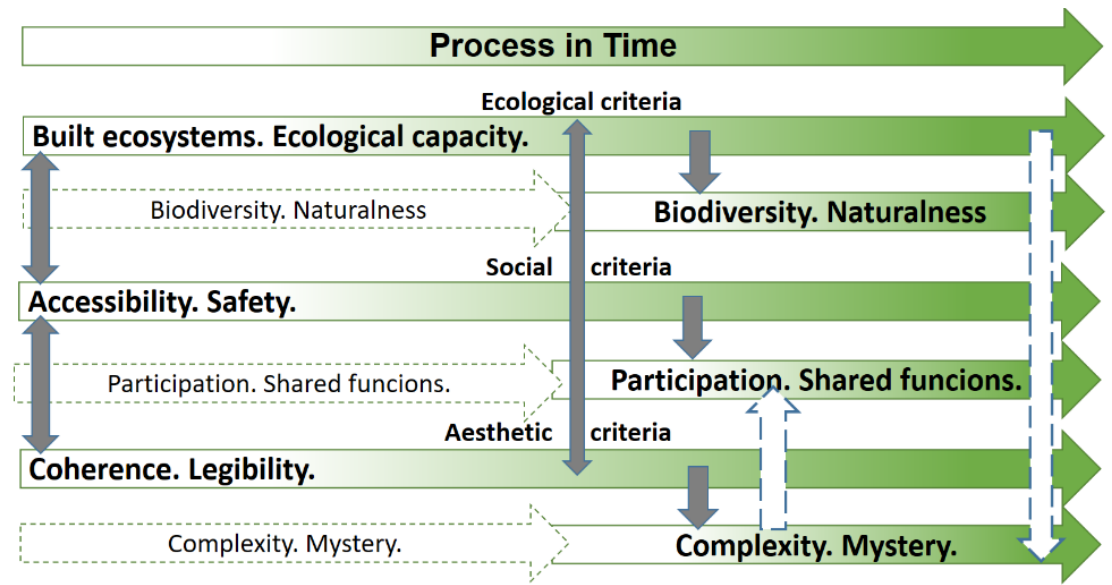

Fig. 3.1. The graphic expression of consistant development in time of values of the interaction between landscape architecture and urban design in terms of criteria.

Source: V. Deveikienè, 2018

It is assumed that a well-designed natural environment consistently acquires higher ecological value over time and at the same time creates aesthetic value of the space. These two values imply social values, but they are also directly dependent on the attitude of the social life actors in creating and supporting these values. The newly developed methodological model includes three main stages of the territory analysis - assessment, prioritization and programme development. The system of criteria chosen for the research, due to its universality, can be applied at various territorial levels, because the criteria include both systemic and local evaluation aspects. The criteria system is diverse, covering the key aspects of the quality of life environment and human needs. Therefore, the same criterion system is suitable for use both in assessing the peculiarities of the current situation and in establishing the priority criteria for improving the quality of the environment. Priorities of criteria are cleared using the multi-criteria analysis method and are compared to the results of the assessment of the current state of the territory. Adequacy or contradictions of the values and priorities identified during the assessment characterize the specifics of the territory.

The typology of landscape management includes the community open space, ecological landscapes, blue-green infrastructure; working-productive landscapes; and transnational landscapes (Desimini, 2013). These types of landscape management are interpreted and applied in the scientific work in order to create a universal landscape typology system linked with other methods and principles used in the model of interaction optimization research.

The spatial grating method implies a contextual approach to the territory under consideration. The specifics of interaction characteristic to the grating is compared to the characteristics of the adjacent grating, looking for the necessary ecological, social and 
aesthetic interfaces. This method encourages the territory to be examined through the landscape prism, going beyond the boundaries of the parcel. It is recommended to associate the problem of interaction between natural and urban structures and solutions of the territory management with neighbourhoods located around in the gratings of the same size. The principle of spatial grating allows a systematic transition from a smaller territorial level to a higher, and vice versa. The research shows that most of the problems of interaction between landscape architecture and urban solutions, and, likely, optimal solutions, can be achieved by studying the problem at the district level. Therefore, for the territory analysis, we consider the $500 \times 500 \mathrm{~m}$ network grate to be the most optimal.

By analyzing the territory fragmented by the spatial grating method, it reveals the differences and similarities of the adjacencies, the weak and strong features of the territory. Properties of the territory and its context are interpreted using a three-dimensional system of criteria and the principles of landscape architecture. The principle of optimality of interaction states that actions must be directed towards the preservation of valuable properties and elimination of problem situations without reducing the established values and focusing on the qualitative parameters of the environment. The central grade under consideration is a reference point and its qualitative changes are oriented towards the properties of neighbouring grates with higher value.

The results of research indicate that natural and urban structures form the integral fabric of the city, and their interaction depends on the ethical attitudes of the urban process participants - the private person, the public, authorities, business enterprises and professional designers, their mutual understanding and collaboration. The methodological model proposes the stages for territory cognition, matching of needs and priorities, combining the nature of the interaction between landscape architecture and urban solutions, and the selection of landscape architecture measures, the whole whereof would constitute the landscape code for a particular location. The model has a complex methodology framework that allows this model to be used as a means of integrating the public, local community, experts and other stakeholders involved in city development processes and enables them to participate in the development of a landscape management code for a specific territory or wider part of the city, or, in other words, long-term development programme (Fig. 3.2.). 


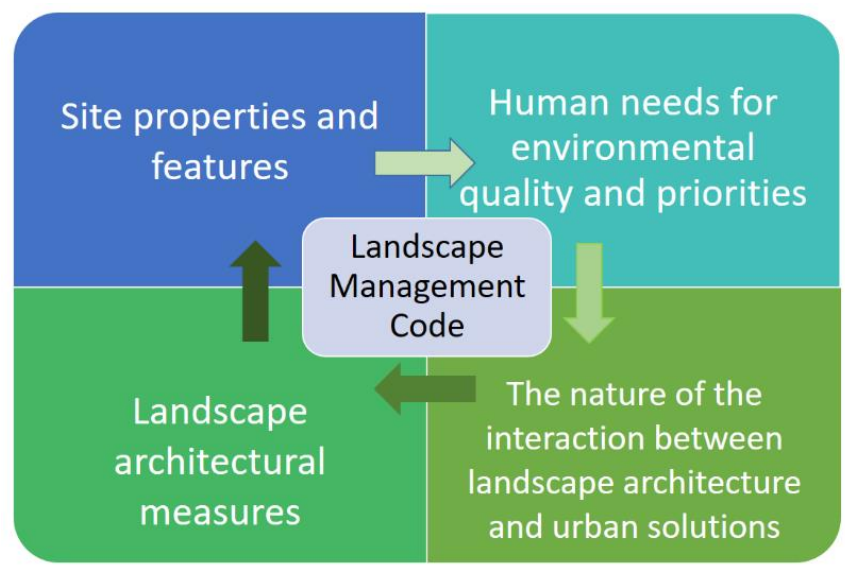

Fig. 3.2. The scheme of landscape management Code generation.

Source: V. Deveikienè, 2018

The methodological model developed by this research work raises of the general principles of interaction between landscape architecture and urban solutions and methodological guidelines for optimization, and forms a platform for further research in a wide range of fields of science, or interdisciplinary research. The research carried out in this work revealed very relevant aspects of the interaction between landscape architecture and urban solutions to be analysed in the future - such as eco-ethics, economics, health, law, inclusion of society, sustainable city, and others. This work briefly discusses the economic, legal and sustainable urban conditions that are important for the application of the methodological model.

\section{General conclusions}

1. The results of the analysis of professional development and professional competency of landscape architecture in urban processes confirmed the hypothesis that landscape architecture is an integral part of a sustainable urban development and city design process, and the nature and extent of the tasks assigned to it depend on the level, priorities and programme of the planning and design of the territory. Practicaly every urban or architectural phenomenon associated with the natural basis or individual natural elements is a potential object of creative activi-ty of landscape architecture.

2. Analysed potential manifestations of interaction between landscape architecture and urban solutions in spatial planning documents. The study revealed that in these spatial planning documents more than one third of tasks are related to the field of landscape architecture. However, none of the plans has demonstrated decisive integrated and complex solutions that enable synergies with landscape architecture.

3. Experts recognized the importance of landscape architecture at various levels of urban development. It shows that landscape architecture measures could be more actively used to optimize the interaction of natural and anthropogenic elements of the city structure. The opinions of the experts of both professions coincide, which testifies to the 
credibility of the statements, the general attitude to the city planning and design priorities, and prospects for further cooperation

4. All urban processes take place in the context of the landscape. The interaction between natural and urban structures is conditioned by the concept of a sustainable city, which is implemented through ecological ethics. The principles of purposefulness and optimality are defined in the values of ecological ethics: the protection of available natural and anthropogenic resources and their cost-effective and creative use; respect to the context and creative adaptation; synergy and adequacy of social services; integration of ecological, aesthetic and social issues into unified solutions. In accordance with the sustainability paradigm, ecological ethics and logic of optimality, a three-dimensional system of evaluation criteria, consisting of ecological, socio-functional and aesthetic criteria groups, is formed.

5. The results of the interaction analysis were conceptualized by applying the landscape architecture principles, methods and tools, which create a new approach to city management and development priorities. Natural and urban structures are consistently interconnected to systems that generate synergistic processes involving all participants in the interaction process. The conditions of applying the methodological model of optimization of interaction where discussed in terms of economical, legal, urban sustainability. It has been determined that the results of the research presuppose further research in the interdisciplinary domain. 


\section{Priedai $^{10}$}

A priedas. Sąvokos „kraštovaizdžio architektūra" raidos analizès suvestinè lentelè

B priedas. II skyriaus iliustracijos ir suvestinès lentelès

C priedas. III skyriaus iliustracijos ir suvestinès lentelès

D priedas. Eksperty apklausos anketos

E priedas. Vertinamos teritorijos duomenys

F priedas. Teritoriju vertinimo rezultatai

G priedas. Daugiakriterinès analizès rezultatai

H priedas. Disertacijos autorès sąžiningumo deklaracija

I priedas. Mokslinių publikacijų bendraautorių sutikimai

J priedas. Autorès mokslinių publikacijų disertacijos tema kopijos

${ }^{10}$ Priedai pateikiami pridètoje kompaktinèje plokštelèje. 


\author{
Vaiva DEVEIKIENE \\ KRAŠTOVAIZDŽIO ARCHITEKTŪROS IR \\ URBANISTIKOS SĄVEIKA \\ Daktaro disertacija \\ Humanitariniai mokslai, \\ menotyra $(03 \mathrm{H})$ \\ INTERACTION BETWEEN LANDSCAPE ARCHITECTURE \\ AND URBANISM \\ Doctoral Dissertation \\ Humanities, \\ History and Theory of Arts $(03 \mathrm{H})$
}

201812 27. 16,0 sp. I. Tiražas 20 egz.

Vilniaus Gedimino technikos universiteto

leidykla „Technika“,

Saulètekio al. 11, 10223 Vilnius,

http://leidykla.vgtu.lt

Spausdino UAB „BMK leidykla““

A. Mickevičiaus g. 5, LT-08119 Vilnius 